\author{
UNIVERSIDADE DE SÃO PAULO \\ Faculdade de Filosofia, Letras e Ciências Humanas \\ Departamento de Letras Clássicas e Vernáculas \\ Programa de Pós-Graduação em Filologia e Língua Portuguesa
}

LARISSA MINUESA PONTES MAREGA

\title{
A PALAVRA EM CENA: \\ O TEXTO DRAMÁTICO NO ENSINO DE LÍNGUA PORTUGUESA
}

Candidata: Larissa Minuesa Pontes Marega

Orientadora: Profa. Dra. Zilda Gaspar Oliveira de Aquino

São Paulo

2015 


\section{A PALAVRA EM CENA: O TEXTO DRAMÁTICO NO ENSINO DE LÍNGUA PORTUGUESA}

Tese apresentada ao Programa de Pós-graduação em Filologia e Língua Portuguesa, do Departamento de Letras Clássicas e Vernáculas, da Faculdade de Filosofia, Letras e Ciências Humanas da Universidade de São Paulo, para obtenção de título de Doutora em Letras.

Área de concentração: Língua Portuguesa

Orientadora: Profa. Dra. Zilda Gaspar Oliveira de Aquino

São Paulo

2015 


\section{FOLHA DE APROVAÇÃO}

Larissa Minuesa Pontes Marega

A palavra em cena: o texto dramático no ensino de língua portuguesa

Tese apresentada ao Programa de Pós-graduação em Filologia e Língua Portuguesa, do Departamento de Letras Clássicas e Vernáculas, da Faculdade de Filosofia, Letras e Ciências Humanas da Universidade de São Paulo, para obtenção de título de Doutora em Letras.

Área de concentração: Língua Portuguesa

Orientadora: Profa. Dra. Zilda Gaspar Oliveira de Aquino

Aprovado em:

\section{Banca Examinadora}

Profa. Dra.:

Instituição:

Assinatura:

Profa. Dra.:

Instituição:

Assinatura:

Prof. Dr.:

Instituição:

Assinatura:

Profa. Dra.:

Instituição:

Assinatura:

Profa. Dra.:

Instituição:

Assinatura: 
A meu marido Gustavo, dono da minha paz, e ao nosso mais valioso projeto de vida: nossos futuros filhos.

A um anjo Rosa no céu, minha querida e amada avó (in memoriam).

Dedico 


\section{AGRADECIMENTOS}

À Professora e Orientadora Zilda Gaspar Oliveira de Aquino, pela orientação dedicada e por me encorajar em todas as etapas desta pesquisa. A minha eterna admiração e meu profundo respeito pela pessoa maravilhosa e pela exímia profissional que é.

À Professora Dra. Maria Aparecida Garcia Lopes-Rossi, pelas valiosas sugestões no exame de qualificação.

Ao Professor Dr. Sandoval Nonato Gomes-Santos, pela leitura cuidadosa que fez de meu trabalho e pelas justas contribuições.

À Professora Dra. Maria Inês Batista Campos, pelos conhecimentos e materiais partilhados.

A meus pais, Jane e Sérgio, pela minha vida.

A meu marido, Gustavo, pela compreensão e pelo amor.

À Prefeitura de Maringá, à Direção e coordenação do Colégio Estadual Rodrigues Alves, por permitirem a viabilização da pesquisa.

Aos professores e alunos participantes das atividades propostas, em especial à turma do $8^{\circ}$ ano E.

À Comissão Científica dos VI e VII EPED, pela construção do conhecimento acadêmico.

A todas as pessoas que, direta ou indiretamente, participaram desta pesquisa, seja pela amizade Elisamari, Dalgisa, Juliana, Marliza, Sara, seja por uma ajuda pontual - Fernando, Filipe, Júlio César, Maria Alice, Solange, Vivian.

À Universidade de São Paulo, pela acolhida e pela ascensão no meio acadêmico.

À CAPES, pela concessão de bolsa de estudos.

A Deus, por tudo isso. Esta obra é resposta de oração. 
É apenas uma rosa, porém, mais importante que todas, pois foi a ela que eu reguei. 


\section{RESUMO}

MAREGA, Larissa Minuesa Pontes (2015). A palavra em cena: o texto dramático no ensino de língua portuguesa. 262 f. Tese (Doutorado) - Faculdade de Filosofia, Letras e Ciências Humanas, Universidade de São Paulo, São Paulo.

Este trabalho teve por objetivo descrever e problematizar a natureza multimodal que o texto dramático (texto escrito para o teatro e texto oralizado/representado) instaura na prática escolar. Assumimos a hipótese de que escolarizar o híbrido constitui-se tarefa complexa, pois que o texto dramático restabelece o vínculo entre estrutura e ação, entre linguagem e corpo, entre saber e prática, exatamente o que a escola denegou como necessidade histórica de se legitimar como forma social autônoma (KRESS, 2000; VINCENT; LAHIRE; THIN, 2001; SOARES, 2002). Para subsidiar este estudo, procedemos a um levantamento de dados que nos aproximou, de forma gradativa, à prática de sala de aula (das representações do que seja ensinar/aprender texto dramático às condições de produção efetivas de ensino e aprendizagem desse gênero discursivo). A investigação das percepções/concepções sobre o ensino de texto dramático foi realizada por meio de análise documental de livros didáticos voltados ao $8^{\circ}$ ano e $9^{\circ}$ anos do ensino fundamental, publicados entre 2008 e 2010, aprovados pelo Programa Nacional do Livro Didático - PNLD (BRASIL, 2010) e pela elaboração e aplicação de questionários a professores da rede pública de ensino, que lecionam língua portuguesa em municípios localizados no norte do Paraná; e alunos de $8^{\text {os }}$ e $9^{\text {os }}$ anos do Colégio Estadual Rodrigues Alves (Maringá-PR). A atuação didática em torno desse gênero correspondeu a uma pesquisa-ação com alunos do $8^{\circ}$ ano do ensino fundamental, no contexto de ensino e aprendizagem do texto dramático na disciplina Língua Portuguesa, totalizando 30h/a. O procedimento buscou promover o seguinte percurso de recepção/produção de textos: assistir a uma peça em um teatro da cidade; ler a peça de teatro a que assistiu; escrever, coletivamente, o próprio texto dramático; encenar o texto que escreveu em um teatro da cidade. Para atender a cada um desses itens, foram elaboradas atividades organizadas em cinco (05) módulos didáticos: 1) Presentificação do Objeto de Ensino; 2) Produção de Leitura; 3) Produção Escrita; 4) Produção Oral e Multimodal e 5) Circulação. Para as discussões e análises foram necessárias várias teorias; dentre elas: a concepção bakhtiniana da linguagem (BAKHTIN/VOLOCHÍNOV, 2002[1929]; BAJTIN/MEDEVEDEV, 2003[1928]; BAKHTIN, 2003[1979], 2005[1929]), a contribuição teórico-metodológica dos pesquisadores genebrinos (DOLZ; SCHNEUWLY, entre outros, 2004), os estudos teatrais para concepção de texto dramático como gênero híbrido (MAGALDI, 1997; PAVIS, 2011; RYNGAERT, 1995; CHACRA, 2010; UBERSFELD, 2010), os pressupostos da multimodalidade que nos autorizam pensar texto dramático no ensino de língua materna (COPE; KALANTZIS, 2000; ROJO, 2009, 2013, 2014, DIONÍSIO, 2011, ROJO; MOURA, 2012; ROJO; BARBOSA, 2015) e a proposta modular para apreensão e produção de gêneros discursivos (LOPES-ROSSI, 2002, 2006, 2011, 2012), que nos ajudaram a desenvolver a pesquisa-ação (THIOLLENT, 2005[1985]; FRANCO, 2005). O estudo evidenciou que o texto dramático constitui desafio para o ensino de língua portuguesa, ao promover: i) a ampliação dos saberes convocados para produção/recepção desse gênero discursivo e de seus modos de apropriação (do escritural para o oral e destes para o multimodal); ii) a experimentação de práticas discursivas engendradas pela esfera teatral (ir ao teatro, efetuar leituras dramáticas, escrever peça, produzir cartazes de divulgação, encenar etc.) e 
iii) o desenvolvimento de competências relacionadas a esse objeto de ensino (linguísticodiscursiva, interacional, comunicativa e expressiva). Nessa direção, o trabalho buscou contribuir para o aprofundamento dos estudos voltados à Linguística Aplicada no que concerne à correlação Arte e ensino de língua portuguesa.

Palavras-chave: Ensino de Língua Portuguesa. Gêneros Discursivos. Texto Dramático. Sequência Didática. Multimodalidade. 


\begin{abstract}
MAREGA, Larissa Minuesa Pontes (2015). The word on stage: dramatic texts in the teaching of Portuguese. 262 f. Doctoral Thesis - Faculty of Philosophy, Letters and Human Sciences, University of São Paulo, São Paulo.
\end{abstract}

This thesis had as its objective describing and problematizing the multimodal nature that dramatic texts (theater-aimed texts and texts to be read aloud/acted out) bring to school practices. The hypothesis of this work in that transforming what is hybrid in a teaching topic is a complex task, since dramatic texts reestablish the bond between structure and action, between language and body, between knowledge and practice, that is, precisely what the school has refused as historical need to legitimate itself as an autonomous social form (KRESS, 2000; VINCENT; LAHIRE; THIN, 2001; SOARES, 2002). In order to make this study possible, data was gathered in a way that has led to the gradual approach to classroom practices (from the representations of what teaching/learning dramatic texts is to the actual requisites for the teaching and learning of this discourse genre). The investigation of the perceptions/conceptions of dramatic text teaching was carried out by means of documental analysis of textbooks published between 2008 and 2010, approved by the National Program of Textbooks (Programa Nacional do Livro Didático PNLD), and aimed at elementary school $8^{\text {th }}$ and $9^{\text {th }}$ graders. Besides that, quizzes were created, to which Portuguese teachers from cities in the north of Paraná and students in the $8^{\text {th }}$ and $9^{\text {th }}$ grades of Rodrigues Alves School (located in Maringá-PR) were asked to provide answers. The didactic practice regarding this genre led to a 30-hour action research sequence involving elementary school $8^{\text {th }}$ graders, in the context of the teaching and the learning of dramatic texts in Portuguese. This procedure sought to promote the following course of action regarding the reception and production of texts: seeing a play in a city theater, reading the play that was seen, writing a dramatic text collectively, and stage it in a city theater. In order to cater for each of those steps, activities were created and organized in five modules: 1) Presentification of the Teaching Topic; 2) Reading; 3) Writing; 4) Oral and Multimodal Production; and 5) Circulation. The discussion and analysis required several theories, among which: Bakhtin's concept of language (BAKHTIN/VOLOCHÍNOV, 2002[1929]; BAJTIN/MEDEVEDEV, 2003[1928]; BAKHTIN, 2003[1979], 2005[1929]), the theoretical and methodological contribution of the Genevan researchers (DOLZ; SCHNEUWLY, and others, 2004), the theatrical studies for the conception of dramatic texts as a hybrid genre (MAGALDI, 1997; PAVIS, 2011; RYNGAERT, 1995; CHACRA, 2010; UBERSFELD, 2010), the theoretical assumptions on multimodality which make it possible to relate dramatic texts and mother language teaching (COPE; KALANTZIS, 2000; ROJO, 2009, 2013, 2014, DIONÍSIO, 2011, ROJO; MOURA, 2012; ROJO; BARBOSA, 2015), and the modular proposal for the apprehension and production of discourse genres (LOPES-ROSSI, 2002, 2006, 2011, 2012), which was one of the bases for the development of the action research sequence (THIOLLENT, 2005[1985]; FRANCO, 2005). This study made it 
evident that dramatic texts pose a challenge to the teaching of Portuguese as it promotes: i) the increment of the knowledge necessary to the production/reception of this discourse genre and its modes of appropriation (from written to oral language and from those to multimodality); ii) the experience with discursive practices inherent to the theater (going to the theater, reading and writing plays, creating posters, acting etc.), and iii) the development of competences related to this teaching topic (linguistic-discursive, interactional, communicative and expressive). This work has intended to contribute to the expansion of Applied Linguistics studies as far as the relationship between Art and Portuguese teaching is concerned.

Keywords: Portuguese Teaching. Discursive Genres. Dramatic Texts. Didactic Sequence. Multimodality. 


\section{LISTAS}

\section{LISTA DE ESQUEMAS}

Esquema 1 -Módulos Didáticos propostos pela pesquisadora Lopes-Rossi (2002, 2006 e 2011).

Esquema 2 - Módulos Didáticos propostos nesta pesquisa.

Esquema 3 - Capa do texto escrito “O Vilarejo”...........190

Esquema 4 - Cena do texto escrito “O Vilarejo”...........191

\section{LISTA DE GRÁFICOS}

Gráfico 1 - Resultados da Questão 06 (QA)

Gráfico 2 - Resultados da Questão 07 (QA)

Gráfico 3 - Resultados da Questão 01 (QA)

Gráfico 4 - Resultados da Questão 02 (QA)

Gráfico 5 - Resultados da Questão 03 (QA).... 166

\begin{tabular}{|c|}
\hline \multirow{2}{*}{ 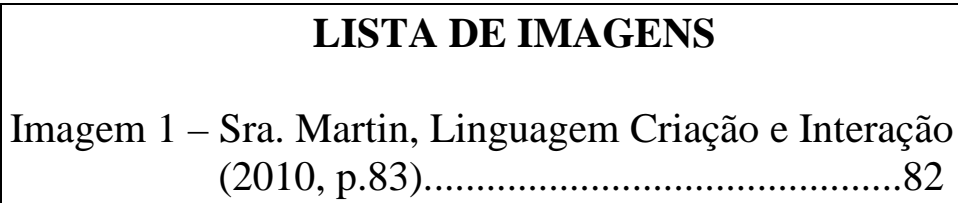 } \\
\hline \\
\hline 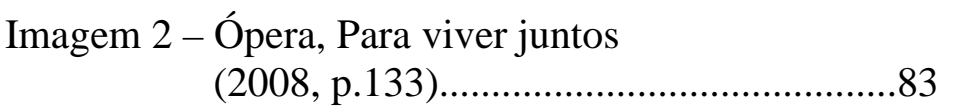 \\
\hline 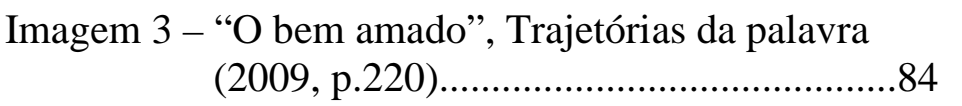 \\
\hline $\begin{aligned} \text { Imagem } 4 \text { - Texto de referência (fragmento), } \\
\text { Para viver juntos (2008, p.134)...............90 }\end{aligned}$ \\
\hline 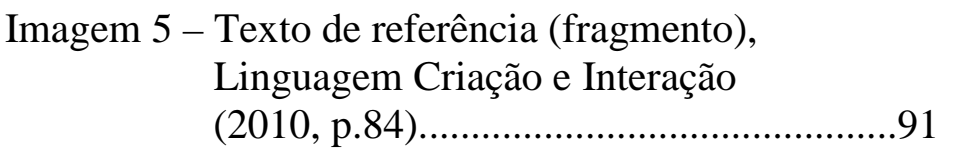 \\
\hline $\begin{aligned} \text { Imagem } 6 \text { - Texto de referência (fragmento), } \\
\text { Português Linguagens (2009, p.18).........92 }\end{aligned}$ \\
\hline 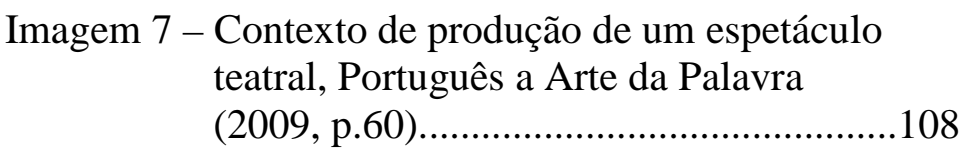 \\
\hline
\end{tabular}




\begin{tabular}{|c|}
\hline 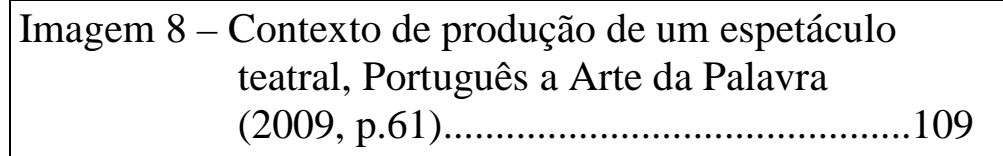 \\
\hline $\begin{array}{r}\text { Imagem } 9 \text { - Municípios atendidos pelo } \\
\text { NRE-Maringá.............................................128 }\end{array}$ \\
\hline Imagem 10 - Heitor nas ruas............................................. \\
\hline Imagem 11 - Cícero e as moças do Vilarejo..................184 \\
\hline Imagem 12 - Heitor e Aurora............................................185 \\
\hline Imagem 13 - A paixão do casal......................................185 \\
\hline Imagem 14 - Alunos do $8^{\circ}$ ano E....................................185 \\
\hline Imagem 15 - Elenco da peça “O Vilarejo”......................185 \\
\hline Imagem 16 - Conhecendo o espaço do teatro.................187 \\
\hline Imagem 17 - Produção escrita.............................................. \\
\hline Imagem 18 - Produção escrita...........................................211 \\
\hline Imagem 19 - Leitura dramática...........................................216 \\
\hline Imagem 20 - Ensaio da Cena 01....................................222 \\
\hline Imagem 21 - Ensaio da Cena 02...................................222 \\
\hline Imagem 22 - Ensaio da Cena 03....................................222 \\
\hline Imagem 23 - Elaboração dos cartazes...........................225 \\
\hline Imagem 24 - Elaboração dos cartazes.............................225 \\
\hline $\begin{array}{l}\text { Imagem } 25 \text { - Cartaz de divulgação da peça } \\
\text { "Festa de Aniversário”................... }\end{array}$ \\
\hline $\begin{array}{l}\text { Imagem } 26 \text { - Programa da peça } \\
\text { "Festa de Aniversário".............................226 }\end{array}$ \\
\hline Imagem 27 - Montagem do cenário................................231 \\
\hline Imagem 28 - Montagem do cenário...............................231 \\
\hline
\end{tabular}




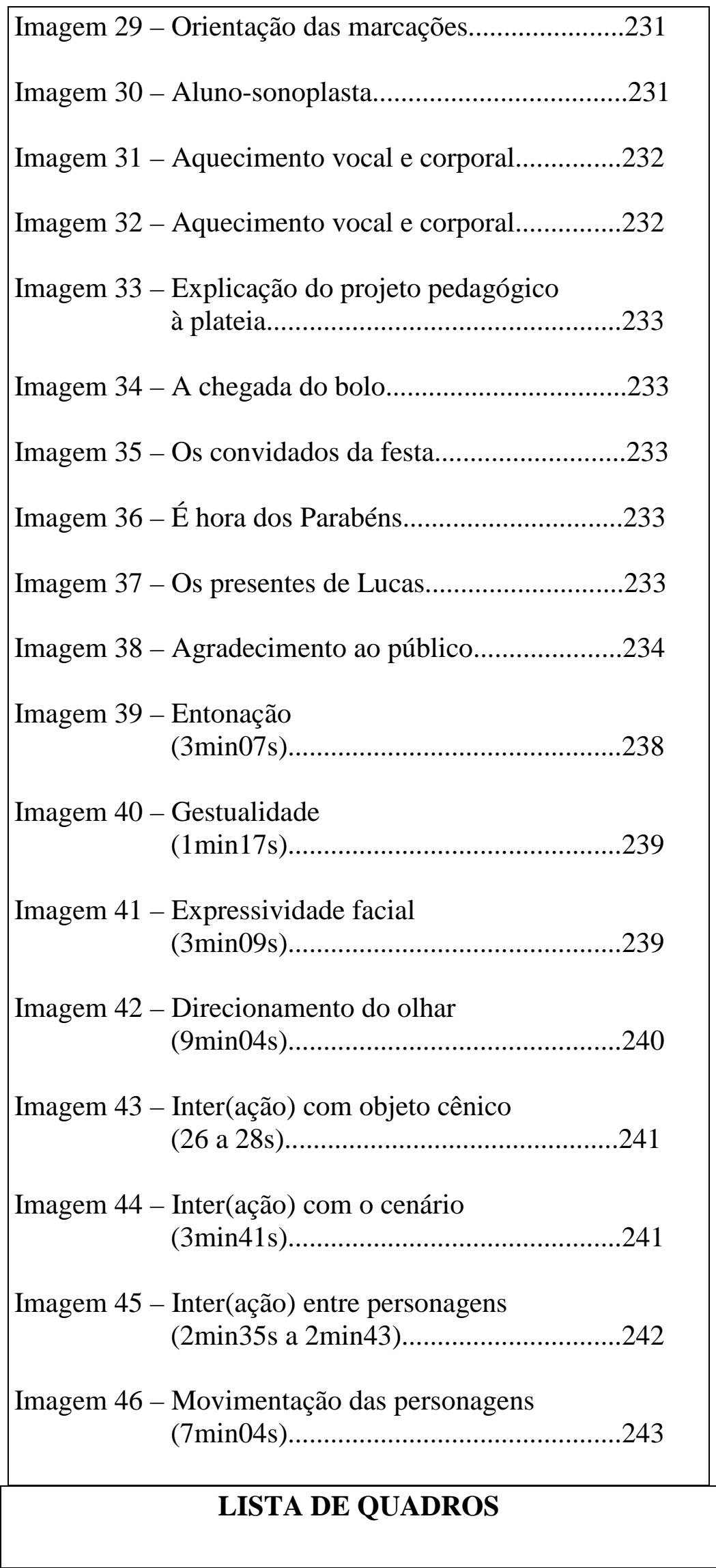


Quadro 1 - Conhecimentos específicos necessários à produção de gêneros discursivos Lopes-Rossi (2012, p.236-7)

Quadro 2 - Livros didáticos analisados. .76

Quadro 3 - Textos dramáticos disponibilizados nos livros didáticos.

Quadro 4 - Categorias de análise para análise dos livros didáticos e resultados

Quadro 5 - Abrangência da aplicação dos questionários aos professores de língua portuguesa.

Quadro 6 - Síntese da sequência didática aplicada.....177

\section{LISTA DE TABELAS}

Tabela 1 - Resultados da Questão 03 (QP) 133

Tabela 2 - Resultados da Questão 04 (QP)..............137

Tabela 3- Resultados da Questão 06 (QP)...............141

Tabela 4 - Resultados da Questão 09 (QP)..............144

Tabela 5 - Resultados da Questão 11 (QP)..............148

Tabela 6 - Resultados da Questão 12 (QP)..............150

Tabela 7- Resultados da Questão 13 (QP)...............153

Tabela 8 - Adesão ao questionário (alunos).............155 


\section{SUMÁRIO}

INTRODUÇÃO.

\section{CAPÍTULO I}

Gênero discursivo: do construto teórico-filosófico à abordagem didático-pedagógica..................24

$1.1 \mathrm{O}$ conceito de gênero discursivo em Bakhtin.........................................................................25

1.2 A emergência do conceito de gênero discursivo nas teorias linguísticas e no ensino de língua portuguesa. .29

1.3 A vertente didática dos gêneros: contribuições do Grupo da Universidade de Genebra..........34

1.3.1 Desdobramentos dos estudos genebrinos no Brasil...................................................36

1.3.2 Projetos pedagógicos em torno da produção de gêneros discursivos.........................38

1.3.3 Módulos didáticos para o ensino de gêneros discursivos: posição metodológica...41

1.3.3.1 Módulo 1 - Presentificação do Objeto de Ensino.........................................43

1.3.3.2 Módulo 2 - Produção de Leitura................................................................44

1.3.3.3 Módulo 3 - Produção Escrita.....................................................................47

1.3.3.4 Módulo 4 - Produção Oral e Multimodal...................................................50

1.3.3.5 Módulo 5 - Circulação..............................................................................52

\section{CAPÍTULO II}

O gênero discursivo texto dramático: um desafio multimodal.......................................................54

2.1 Da nomeação do objeto de investigação: texto dramático..........................................................55

2.2 Texto dramático escrito versus texto dramático oralizado/representado.................................56

2.3 Relações de interdependência entre texto dramático escrito e texto dramático oralizado/representado.............................................................................................................59

2.3.1 Possibilidades de interlocução do texto dramático (escrito e oralizado/representado)................................................................................................60

2.3.2 O texto dramático escrito e sua projeção para o palco...............................................63

2.4 Para pensar o texto dramático nos estudos linguísticos: Letramento(s), Multiletramentos e Multimodalidade. 65

2.5 Para pensar o texto dramático no ensino de língua portuguesa: do escritural para o multimodal..............................................................................................................................72

\section{CAPÍTULO III}

O texto dramático em livros didáticos de língua portuguesa............................................................74

3.1 Apresentação do material didático......................................................................................74

3.1.1 Abertura do capítulo...................................................................................................78

a) Ativação do conhecimento prévio a respeito do objeto de ensino......................79

b) Proposição de atividades em torno do objeto de ensino.....................................85

c) Definição e topicalização do objeto de ensino....................................................87

3.1.2 Atividades de leitura e compreensão de textos...........................................................90

a) O texto dramático é um texto narrativo e pertence à esfera literária...............95

b) Ainda que o texto dramático escrito seja um texto narrativo, ele apresenta uma estrutura composicional diferenciada dos outros textos narrativos.......................97

c) O texto dramático escrito convoca a uma encenação........................................100

3.1.3 Propostas de produção escrita e oral..........................................................................110 
a) Criação de rubricas, esquemas e cenas.......................................................111

b) Adaptação de textos narrativos em textos dramáticos.....................................112

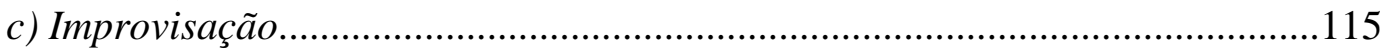

d) Leitura dramática...............................................................................116

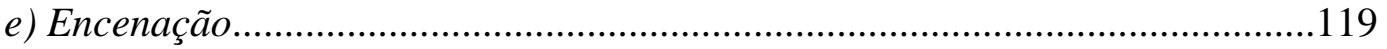

3.2 Resultados das análises.

CAPÍTULO IV

O texto dramático sob o olhar de professores de língua portuguesa e de

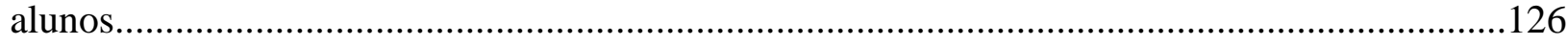

4.1. Condições de produção dos questionários....................................................................127

4.1.1 Primeiros resultados: em cena, o professor de língua portuguesa..........................131

a) $O$ texto dramático aproxima-se do modo escritural do texto narrativo.

b) O texto dramático escrito possibilita o trabalho com a modalidade oral da

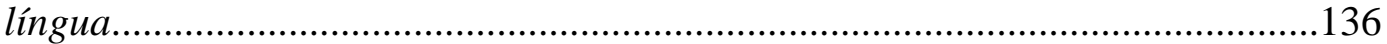

c) O texto dramático relaciona-se a múltiplos modos de linguagem....................147

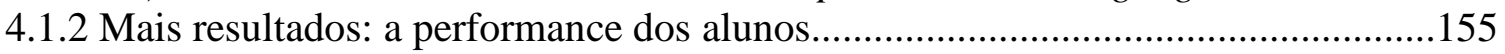

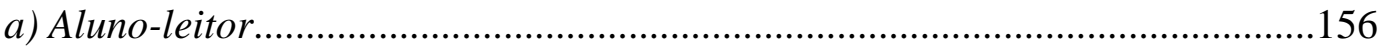

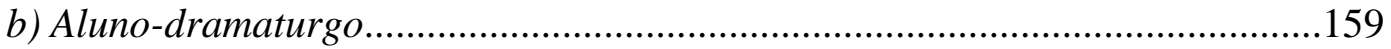

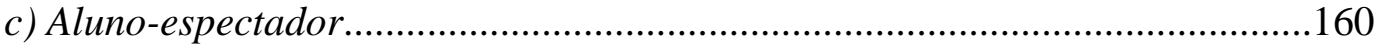

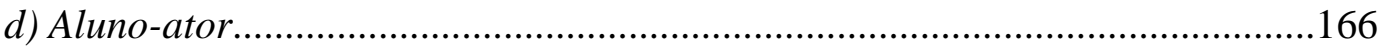

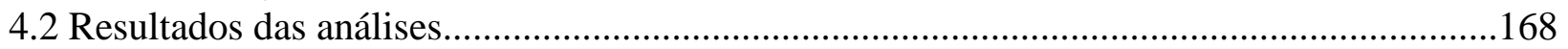

CAPÍTULO V

Pesquisa-ação: proposta de sequência didática em torno do gênero discursivo texto

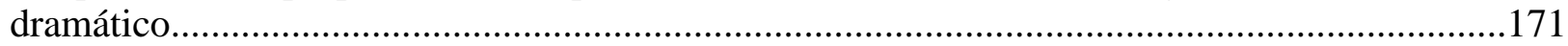

5.1 Pesquisa-ação: aportes teórico-metodológicos.............................................................172

5.2 Sujeitos participantes da pesquisa-ação......................................................................174

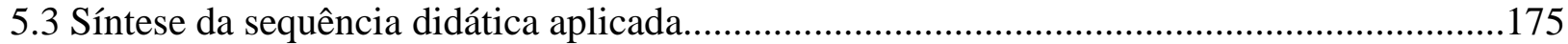

5.3.1 Módulo 1 - Presentificação do Objeto de Ensino.................................................180

5.3.1 Módulo 2 - Produção de Leitura...........................................................................189

5.3.3 Módulo 3 - Produção Escrita..............................................................................200

5.3.4 Módulo 4 - Produção Oral e Multimodal...........................................................215

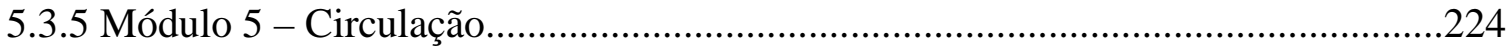

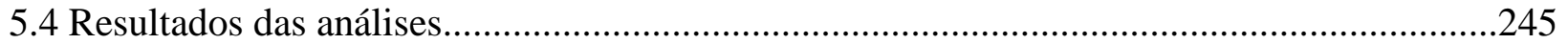

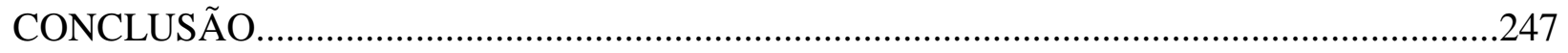

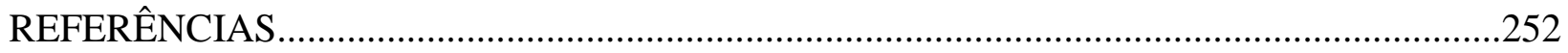

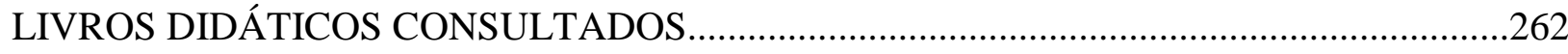

ANEXOS (CD-ROM) 


\section{INTRODUÇÃO}

A pesquisa em torno do ensino dos gêneros discursivos tem sido do interesse de muitos pesquisadores brasileiros, em diferentes linhas teóricas; dentre elas, destacamos, especialmente, os que se coadunam à vertente bakhtiniana e promovem o diálogo entre os conceitos de Bakhtin e seu Círculo (BAKHTIN/VOLOCHÍNOV, 2002[1929]; BAJTIN/MEDEVEDEV, 2003[1928]; BAKHTIN, 2003[1979], 2005[1929]) e os gêneros discursivos (LOPES-ROSSI, 2002, 2006, 2011, 2012; COSTA-HÜBES, 2014; ROJO, 2014). Destacamos, também, o Interacionismo Sociodiscursivo (SAITO; NASCIMENTO, 2005; BARROS; NASCIMENTO, 2007; MACHADO; CRISTÓVÃO, 2009; MACHADO; CRISTÓVÃO; GUIMARÃES, 2009; CRISTÓVÃO; NASCIMENTO, 2011; NASCIMENTO, 2009), em que se apresentam propostas que retomam o procedimento "sequência didática", cunhado pelos pesquisadores do chamado Grupo da Universidade de Genebra (SCHNEUWLY; DOLZ et alii, 2004). Finalmente, observamos a Linguística Textual, da qual salientamos o investimento de Marcuschi, em seus trabalhos de 2008, 2010 e 2011, para divulgação e discussão da categoria "gênero" nas teorias linguísticas.

Ressaltamos, nessa direção, a quantidade de obras publicadas, entre 2009 e 2014, organizadas por estudiosos brasileiros que buscam entrelaçar gênero e ensino de língua (portuguesa ou estrangeira), ao focalizarem os vários níveis de ensino (fundamental, médio, superior, educação de jovens e adultos, formação continuada) e ao discutirem as práticas de letramentos - na produção de leitura e na produção de textos (escritos e orais). Essas propostas apontam para a didatização de inúmeros gêneros discursivos, contribuindo para o trabalho docente, no que diz respeito, por exemplo, à construção e apreensão dos saberes escolares e das capacidades de linguagem necessárias à produção/recepção de textos.

Observamos, ainda, que a produção dos estudos linguísticos sob a perspectiva dos multiletramentos, divulgada amplamente pelo chamado Grupo de Nova Londres (COPE; KALANTZIS, 2000), caminha para a complexidade de se pensar as múltiplas semioses (verbal, verbo-visual, corporal, sonora, entre outras) que constituem os textos da hipermodernidade. Na era digital, destacam-se gêneros hipermidiáticos (animações, games, videoclipes, entre outros) que se constroem de modo multissemiótico. Em solo nacional, Rojo 
(2009, 2013, 2014), Dionísio (2011), Rojo e Moura (2012) e Rojo e Barbosa (2015) têm discutido questões dessa ordem, que envolvem o estudo de gêneros discursivos multimodais e sua relação com a escola, a mídia, a cultura e a sociedade.

O presente trabalho insere-se nos estudos de Linguística Aplicada ao ensino de língua portuguesa, e convoca à cena acadêmico-científica a discussão de uma proposta de escolarização do gênero discursivo texto dramático. Ao contrário dos gêneros multimodais que configuram as práticas contemporâneas, mencionadas anteriormente, entendemos que o texto dramático (texto escrito para o teatro) acompanha uma historicidade milenar e tem no diálogo e na ação características primordiais, conforme asseguram os estudos teatrais (PAVIS, 2008; UBERSFELD, 2010). Nossa compreensão decorre dos estudos e atuação no teatro ao longo de dez anos, e da observação das possibilidades de um investimento que recobrisse as duas áreas de ensino com as quais nos envolvemos - nas Artes, o teatro, na Língua Portuguesa, os gêneros discursivos.

Em vista disso, e pelos motivos já mencionados, elegemos o texto dramático como objeto de investigação desta pesquisa. $O$ trabalho justifica-se pelo fato de se conhecerem poucas pesquisas direcionadas à aplicação desse gênero no ensino de língua materna. No Brasil, observamos o trabalho de Guimarães, Campani-Castilhos e Drey (2008), em torno da peça de teatro infantil para alunos de $4^{\circ}$ ano do ensino fundamental e uma proposta de produção de material didático voltada para os anos finais do ensino fundamental - que não se constitui aplicação -, de autoria coletiva (DONEGÁ et alii, 2009), como resultado da Disciplina Estágio Supervisionado do Curso de Letras (Instituto de Estudos da Linguagem Unicamp), sob orientação da Profa. Dra. Márcia Azevedo de Abreu. Em contexto lusófono, destacamos a aplicação didática de Diegues (2010), com a proposta de atividades de leitura do texto dramático para alunos do ensino médio.

Sabemos que o teatro tem sido vastamente discutido no âmbito ficcional, literário, lúdico-pedagógico de sua prática, de seus temas, de seu contexto de produção: autores, artistas e obras; sua riqueza de situações, teorias e métodos envolve parte de um material que permite conduzir distintas investigações. A esfera do teatro se apresenta, pois, como um lugar privilegiado de experimentação e interrogação que se alarga para estudos voltados às distintas correntes teóricas e que acreditamos, também, possa ser produtivo para estudos voltados à linguagem, subsidiados pela teoria dos gêneros discursivos e da multimodalidade. 
Uma vez escolarizados, entendemos que os gêneros discursivos adquirem, por hipótese, um funcionamento particular - um modo de ser e apreender, comunicar e produzir sentidos. No contexto de ensino de língua materna, partimos do pressuposto de que o texto dramático possa contribuir para o desenvolvimento de competências linguístico-discursivas, comunicativas, interativas e expressivas dos alunos, pelo fato de sua natureza multimodal permitir o ler-escrever, o ouvir-falar, o gesticular-assistir.

Assumimos, com isso, a hipótese de que escolarizar um gênero multimodal constituise tarefa complexa, pois que o texto dramático restabelece o vínculo entre estrutura e ação, entre linguagem e corpo, entre saber e prática, exatamente o que a escola denegou como necessidade histórica de se legitimar como forma social autônoma (KRESS, 2000; VINCENT; LAHIRE; THIN, 2001; SOARES, 2002). Em outras palavras, possibilitar que o gênero discursivo texto dramático circule em uma instituição que preconiza o saber escritural significa encontrar desafios, em vários sentidos: no trabalho do professor (administração do tempo escolar, elaboração de atividades, aplicação de métodos e organização de recursos), na produção/envolvimento dos alunos e na postura da escola frente a mudanças, por se tratar, assim, de mudança de parâmetros.

Diante desse quadro, algumas questões passam a nortear esta pesquisa: De que maneira é possível abordar o texto dramático, a partir de uma concepção de gênero discursivo multimodal? O que ocorre quando esse gênero é escolarizado? A essas duas questões, associamos outras:

- Do ponto de vista dos saberes: Qual(is) concepção(ões) de texto dramático é (são) convocada(s) para produção/recepção desse gênero?

- Do ponto de vista do método: Quais práticas solicitar para o ensino? Quais dispositivos didáticos necessários ao trabalho do professor?

- Do ponto de vista da aprendizagem: De que modo os alunos apreendem esse gênero?

- Do ponto de vista dos usos da linguagem: Quais competências são requeridas?

Diante do exposto, este trabalho se apresenta como proposta de escolarização do gênero (multimodal) texto dramático no ensino de língua portuguesa e tem por objetivos: 
Geral:

- Contribuir para o aprofundamento dos estudos voltados à Linguística Aplicada no que concerne à correlação Arte e ensino de Língua Portuguesa.

Específicos:

- Descrever e problematizar a natureza multimodal do texto dramático, a fim de evidenciar particularidades que fazem desse gênero discursivo objeto potencial para o ensino de língua portuguesa.

- Investigar as concepções/percepções sobre o ensino do texto dramático que circulam na escola, com intuito de observar se apontam para multimodalidade ou nos dão pistas sobre a versão escolarizada desse gênero discursivo.

- Observar a aplicação de uma sequência didática voltada para a produção/recepção do texto dramático em contexto de ensino e aprendizagem de língua portuguesa, para conhecer os desdobramentos e os resultados que a natureza multimodal do texto dramático pode instaurar na prática escolar.

A hipótese e os objetivos estabelecidos conduziram-nos a uma investigação em torno das percepções sobre o ensino do texto dramático. Para subsidiar esse estudo, realizamos um levantamento de dados que nos pudesse aproximar, de forma gradativa, à prática de sala de aula (das representações do que seja ensinar/aprender texto dramático às condições de produção efetivas de ensino e aprendizagem desse gênero discursivo). Desse modo, apresentamos, a seguir, os procedimentos metodológicos adotados nesta pesquisa e que englobam: Análise Documental, Elaboração de Questionários e Pesquisa-ação.

Procedemos à Análise Documental, a partir do que propõem Lüdke e André (1986), e selecionamos para observação e análise oito (08) livros didáticos, publicados entre 2008 e 2010. O critério de seleção do material compreendeu a leitura do Guia do Programa Nacional do Livro Didático (BRASIL, 2010), que apresenta, em resenhas das coleções aprovadas no triênio 2011-2013, o texto dramático como objeto de estudo de seis (06) livros didáticos voltados ao $8^{\circ}$ ano e dois (02) destinados ao $9^{\circ}$ ano do ensino fundamental. Como categorias de análise, elegemos: abertura do capítulo, atividades de leitura e compreensão textual, propostas de produção escrita e oral. 
Outro procedimento adotado correspondeu à Elaboração de Questionários, do modo como propõem Lüdke e André (1986), que aplicamos a noventa e nove (99) professores da rede pública de ensino, que lecionam língua portuguesa em municípios localizados no norte do Paraná; e a cento e setenta e sete (177) alunos de $8^{\text {os }}$ e $9^{\text {os }}$ anos do Colégio Estadual Rodrigues Alves (Maringá-PR). O encaminhamento das análises constituiu-se, por um lado, das concepções de texto dramático evocadas pelas respostas dos professores do ponto de vista da proposição de práticas discursivas (de leitura, escrita e de natureza multimodal) e, por outro, do conhecimento que os alunos revelaram ter a respeito do texto dramático.

O procedimento final constitui-se de Pesquisa-ação, sob a perspectiva de Thiollent (2005[1985]) e Franco (2005), e foi realizada junto aos alunos do $8^{\circ}$ ano E do Colégio Estadual Rodrigues Alves (Maringá-PR). Para o desenvolvimento das atividades, selecionamos o procedimento "sequência didática", preconizado pelos pesquisadores genebrinos (SCHNEUWLY; DOLZ et alii, 2004) e desenvolvemos cinco (05) módulos de ensino, a partir da contribuição metodológica de Lopes-Rossi (2002, 2006, 2011, 2012) e de nossa adaptação para estudo, produção/recepção do texto dramático: 1) Presentificação do Objeto de Ensino; 2) Produção de Leitura; 3) Produção Escrita; 4) Produção Oral e Multimodal e 5) Circulação.

Os primeiros conjuntos de dados coletados, correspondentes à análise de livros didáticos e questionários a professores e alunos, configuram-se subsidiários em relação ao terceiro conjunto - pesquisa-ação. Em outras palavras, a aplicação de sequência didática e o acompanhamento de seus resultados compreendem o centro de nossa investigação; tal hierarquização dos dados justifica-se pela necessidade de dar a conhecer o estado da arte do gênero discursivo selecionado para esta pesquisa - texto dramático -, tendo em vista a escassez de estudos acadêmico-científicos que o caracterizam no contexto de ensino e aprendizagem de língua materna. Ressaltamos que o fio condutor que atravessa as análises desse material delineia-se a partir da natureza multimodal do texto dramático e a descrição pormenorizada de cada procedimento indicado se faz presente no capítulo em que cada um deles foi utilizado.

Vale observar que nos apoiamos, também, na posição de estudiosos, como Machado, Cristóvão e Guimarães (2009), para quem as pesquisas voltadas à vertente didática dos gêneros discursivos possam constituir ampliação e renovação dos procedimentos 
metodológicos elaborados pelos pesquisadores genebrinos, promovendo, assim, a criação de novas sequências e de sua aplicação em outros contextos de ensino.

A fim de cumprir a proposta apresentada, organizamos o trabalho em cinco (05) capítulos. No capítulo I, discutimos a incursão dos postulados bakhtinianos a respeito dos gêneros discursivos no cenário de produção acadêmico-científica brasileiro, a partir da contribuição teórico-metodológica dos pesquisadores do chamado Grupo da Universidade de Genebra (SCHNEUWLY; DOLZ et alii, 2004). Apresentamos, também, os módulos de ensino que configuram nossa proposta de sequência didática em torno do gênero discursivo texto dramático, subsidiada pelos trabalhos de Lopes-Rossi (2002, 2006, 2011, 2012).

Para compreender o estatuto de nosso objeto de investigação (texto dramático), evidenciamos no capítulo II a relação de interdependência constitutiva em seus planos de produção - escrita, oral e multimodal (PEIXOTO, 1986; ROSENFELD, 1993; MAGALDI, 1997; PAVIS, 2011), suas possibilidades de interlocução (RYNGAERT, 1995; CHACRA, 2010; SPOLIN, 2010; UBERSFELD, 2010) e seu construto heterogêneo (HELBO, 1989; TORO, 1989; PAVIS, 2008). Reportamo-nos aos estudos teatrais para conceituação e caracterização de nosso objeto de pesquisa e às teorias linguísticas que nos autorizam pensar texto dramático como objeto de ensino de língua materna (COPE; KALANTZIS, 2000; ROJO, 2009, 2013, 2014, DIONÍSIO, 2011, ROJO; MOURA, 2012; ROJO; BARBOSA, 2015).

No capítulo III, focalizamos o modo como os autores dos livros didáticos abordam o texto dramático. Analisamos, assim, as páginas de abertura da unidade, para observar como o objeto de ensino é apresentado ao aluno, as atividades de leitura e compreensão textual e as propostas de produção escrita e oral do texto dramático, para verificar as concepções sobre esse objeto, tendo em vista sua natureza multimodal.

No capítulo $I V$, dedicamo-nos, primeiramente, à interpretação dos resultados obtidos na aplicação de questionários a professores de língua portuguesa, com o objetivo de conhecer a concepção de texto dramático que evoca das respostas apreendidas e os dados que sinalizam a escolarização desse gênero discursivo. Observamos, também, as respostas dos alunos, quanto às suas experiências/práticas nos papéis de aluno-dramaturgo, aluno-ator, aluno-leitor e aluno-espectador. 
Descrevemos no capítulo $V$ a pesquisa-ação realizada junto aos alunos do $8^{\circ}$ ano $\mathrm{E}$, do Colégio Estadual Rodrigues Alves (Maringá-PR). Ao eleger o gênero discursivo texto dramático como objeto de ensino e aprendizagem de língua portuguesa, conduzimos a aplicação de uma sequência didática, a fim de promover o seguinte percurso de produção/recepção de textos: 1) assistir a uma peça de teatro; 2) ler a peça de teatro a que assistiu; 3) escrever o próprio texto dramático e 4) encenar o texto que escreveu. As atividades foram organizadas nos cinco (05) módulos explicitados no capítulo I. 


\section{CAPÍTULO I}

\section{Gênero discursivo: do construto teórico-filosófico à abordagem didático-pedagógica}

A teatralidade é essencialmente humana. Todo mundo tem dentro de si o ator e o espectador.

Augusto Boal

Neste capítulo, reportamo-nos à concepção bakhtiniana da linguagem, com o propósito de evidenciar o cenário que inspirou a vasta mobilização e apropriação - sobretudo na última década, no Brasil - do conceito de gênero discursivo, por parte do discurso didáticopedagógico. Buscamos enfatizar, também, a contribuição dos pesquisadores do chamado Grupo da Universidade de Genebra ${ }^{1}$ e os desdobramentos desses estudos em nosso país. Apresentamos, finalmente, o procedimento sequência didática - e os módulos de ensino - que sustenta a proposta metodológica de pesquisa-ação presente neste trabalho.

À luz da teoria bakhtiniana, não nos é permitido pensar em gênero como uma categoria isolada. Em consonância ao modus operandi de Bakhtin e de seu Círculo², trataremos da questão a partir do diálogo com outros conceitos-chave, de igual importância, e que merecem destaque por ancorarem a noção de gênero discursivo, e por atravessarem e

\footnotetext{
${ }^{1}$ Notadamente representado por Bernard Schneuwly, Joaquim Dolz et alii - Michèle Noverraz, Sylvie Haller, Gabrielle Zahnd, Jean-François de Pietro. Os trabalhos destes autores foram traduzidos pelas pesquisadoras brasileiras Rojo e Cordeiro e reunidos na obra Gêneros orais e escritos na escola (2004).

${ }^{2}$ Nome atribuído a um grupo de intelectuais russos que se reuniam regularmente entre 1919 e 1929. Para Faraco (2009), três desses intelectuais merecem destaque - Bakhtin, Voloshinov e Medvedev.
} 
constituírem, desse modo, o arcabouço teórico dos pensadores russos. Nas linhas que seguem, apresentamos os conceitos que conformam essa discussão: a interação verbal e as relações dialógicas.

\title{
1.1 O conceito de gênero discursivo em Bakhtin
}

Ao longo de sua produção filosófica, Bakhtin arquitetou uma sólida teoria sobre a linguagem. Segundo Brait (2005), o enfrentamento do autor se dá com um instrumental diferente daquele empregado na linguística saussuriana ou na estilística tradicional. Em Marxismo e Filosofia da Linguagem (2002[1929]), o pensador russo dialoga com as duas tendências linguísticas vigentes na época, e identifica-as como objetivismo abstrato e subjetivismo idealista. A partir disso, direciona seu posicionamento,

\begin{abstract}
A verdadeira substância da língua não é constituída por um sistema abstrato de formas linguísticas nem pela enunciação monológica isolada, nem pelo ato psicofisiológico de sua produção, mas pelo fenômeno social da interação verbal realizada através da enunciação ou das enunciações. A interação verbal constitui assim a realidade fundamental da língua (BAKHTIN/VOLOCHÍNOV, 2002[1929], p.123, grifos do autor).
\end{abstract}

Sob este enfoque, o fenômeno da interação verbal define-se pela adesão a uma concepção de linguagem como atividade sociointeracional. Em Estética da Criação Verbal, Bakhtin (2003[1979]) reforça o fio condutor de seu pensamento sobre a linguagem: "estamos interessados primordialmente nas formas concretas dos textos e nas condições da vida dos textos, na sua inter-relação e interação" (BAKHTIN, 2003[1979], p.319).

Para Bakhtin/Volochínov (2002[1929]), a natureza da palavra ocorre na sua interdiscursividade, e é justamente esta instância sociocomunicativa que dá condição à palavra de agir. Segundo o autor, 
[...] toda palavra comporta duas faces. Ela é determinada pelo fato de que procede de alguém como pelo fato de que se dirige para alguém. Ela constitui justamente o produto da interação do locutor e do ouvinte. Toda palavra serve de expressão a um em relação ao outro. Através da palavra defino-me em relação ao outro, isto é, em última análise, em relação à coletividade. A palavra é uma espécie de ponte lançada entre mim e os outros. Se ela se apóia sobre mim numa extremidade, na outra apóia-se sobre o meu interlocutor. A palavra é o território comum do locutor e do interlocutor (BAKHTIN/VOLOCHÍNOV, 2002[1929], p.113, grifos do autor).

A interação verbal se estabelece como condição de uso da linguagem e, compreende, nesse sentido, a existência de dois sujeitos historicamente situados, que estabelecem a comunicação ao se alternarem entre os papéis de sujeitos falantes, definindo-se, também, no momento em que assumem tais papéis.

Conforme salienta Faraco (2009), o ponto de partida da obra bakhtiniana é a estipulação de um vínculo orgânico entre a utilização da linguagem e a atividade humana. Toda atividade humana evoca linguagem e toda linguagem está circunscrita em uma atividade humana; em Bakhtin (2003[1979]), essa relação é sempre recíproca e, antes de tudo, dialógica.

O próprio construto teórico do conjunto da obra do Círculo exorta o princípio unificador de seu pensamento: uma orientação dialógica da linguagem que se manifesta na vida. Reportamo-nos, assim, ao cerne do pensamento bakhtiniano, nas palavras de Fiorin (2011, p.51), "a linguagem penetra na vida por meio dos enunciados concretos e, ao mesmo tempo, pelos enunciados a vida se introduz na linguagem”. Dessa maneira, são dialógicas as relações entre pessoas, entre discursos, entre pessoas e discursos.

Em Problemas da Poética de Dostoiévski (2005[1929]), Bakhtin afirma que as relações dialógicas são sempre extralinguísticas. Para o autor,

A linguagem só vive na comunicação dialógica daqueles que a usam. É precisamente essa comunicação dialógica que constitui o verdadeiro campo da vida da linguagem. Toda a vida da linguagem, seja qual for o seu campo de emprego (a linguagem cotidiana, a prática, a científica, a artística, etc.), está impregnada de relações dialógicas (BAKHTIN, 2005[1929], p.183, grifo do autor). 
Na concepção bakhtiniana de linguagem, todo enunciado evoca uma resposta que lhe é constitutiva. Quando alguém assume a palavra, assume-a a partir de outras que a precederam e aponta para outras vindouras; assume, pois, uma interlocução. A produção do enunciado caracteriza-se, por assim dizer, como atitude e ressonância dialógica: todo enunciado é pleno da palavra de outros, reflete e refrata sentidos. Nas palavras do autor, "qualquer tipo genuíno de compreensão deve ser ativo, deve conter já o germe de uma resposta" (BAKHTIN/VOLOCHÍNOV, 2002[1929], p.131), e ainda, "a palavra quer ser ouvida, entendida, respondida e mais uma vez responder à resposta, e assim ad infinitum" (BAKHTIN, 2003[1979], p.334).

Em meio a essa reflexão filosófica sobre a linguagem, emerge o conceito de gênero discursivo: número infinito de práticas textuais, históricas e sociais que viabilizam a possibilidade da comunicação humana, e que se valem, necessariamente, de todo e qualquer uso da linguagem - oral e/ou escrita, compondo um todo heterogêneo à disposição de produtores e interlocutores.

Com efeito, a interdependência dos gêneros discursivos às atividades da comunicação humana é característica da obra do Círculo. Para Bakhtin (2003[1979]), as pessoas agem e interagem em enunciados concretos; e estes, por sua vez, agem e interagem em relação com a vida. Em outras palavras, a unidade da comunicação discursiva apresenta-se imediata e profundamente vinculada à história e à realidade das pessoas. O gênero é, pois, duplamente orientado, estabelece-se na relação com os interlocutores e fundamenta-se na relação com a vida. Em O método formal dos estudos literários, Bajtin/Medevedev (2003[1928], p.209) destaca que

\begin{abstract}
A totalidade artística de qualquer tipo, ou seja, de qualquer gênero, aparece duplamente orientada na realidade, e as particularidades desta orientação determinam o tipo da totalidade, ou seja, o gênero. Uma obra está orientada, em primeiro lugar, para ouvintes e receptores e para específicas condições de produção e recepção. Em segundo lugar, uma obra está orientada para vida ${ }^{3}$.
\end{abstract}

\footnotetext{
${ }^{3}$ Tradução nossa de: "La totalidad artística de cualquier tipo, es decir, de cualquier género, aparece doblemente orientada en la realidad, y las particularidades de esta doble orientación determinan el tipo de la totalidad, es decir, el género. Una obra está orientada, em primer lugar, hacia los oyentes y los receptores y hacia las determinadas condiciones de la ejecución y percepción. En segundo lugar, uma obra está orientada en la vida".
} 
Na abordagem sociológica de Bakhtin (2003[1979]), as formas da língua e os gêneros do discurso se entrelaçam e chegam juntos, a um só tempo, desde tenra idade, no momento em que nos deparamos com o mundo letrado. Uma criança, mesmo ainda muito pequena, sabe o que dizer, como dizer, a quem dizer e quando dizer; e sabe se adequar às diversas situações que lhes são impostas no dia a dia. A comunicação humana, assim, sustenta-se em formas típicas de enunciados que apresentam certa regularidade - sensivelmente (re)conhecida e situada - que nos permite, de maneira dialógica, comunicar, compreender, responder. Para o autor:

Esses gêneros do discurso nos são dados quase da mesma forma que nos é dada a língua materna, a qual dominamos livremente até começarmos o estudo teórico da gramática. A língua materna - sua composição vocabular e sua estrutura gramatical - não chega ao nosso conhecimento a partir de dicionários e gramáticas, mas de enunciações concretas que nós mesmos ouvimos e nós mesmos reproduzimos na comunicação discursiva viva com as pessoas que nos rodeiam (BAKHTIN, 2003[1979], p.282).

No bojo da teoria bakhtiniana, o uso da linguagem é definido pelo campo de comunicação da atividade humana em que aparece e é determinado pela relação orgânica e indissolúvel entre três componentes, a saber: tema, estilo e estrutura composicional. Da interrelação destes componentes, emergem os gêneros discursivos (e diversos) que, na historicidade, se atualizam, se transformam e, por isso, reconhecem-se dinâmicos.

Assim, parece-nos substancial conhecer (e tornar conhecida) a eminência comunicativa que nos permite uma socialização mais adequada. De acordo com Bakhtin (2003[1979], p.285), quanto melhor dominamos os gêneros

[...] tanto mais livremente os empregamos, tanto mais plena e nitidamente descobrimos neles a nossa individualidade (onde isso é possível e necessário), refletimos de modo mais flexível e sutil a situação singular da comunicação; em suma, realizamos de modo mais acabado o nosso livre projeto de discurso.

Em uma palavra, podemos entender que os gêneros discursivos coexistem com nosso agir verbal e, ao dominá-los, aprimoramos nossa vivência com a linguagem e, consequentemente, com os outros. 
Afirmamos no início deste capítulo que o conceito de gênero reverbera de maneira contundente em nosso país, de forma a servir como eixo norteador para o discurso didáticopedagógico. Ao discutir o conceito oriundo das reflexões bakhtinianas sobre a linguagem, Fiorin (2011, p.56) resume a questão em poucas palavras: "fala-se e escreve-se sempre por gêneros e, portanto, aprender a falar e a escrever é, antes de mais nada, aprender gêneros”.

O entendimento e o (re)conhecimento de que o conceito de gênero é pertinente, hoje, para o ensino de língua portuguesa (como objeto de ensino), entretanto, antecedeu o percurso histórico da própria disciplina, a qual acompanhou, de modo considerável, a evolução das teorias linguísticas. É o que nos propomos a discutir.

\subsection{A emergência do conceito de gênero discursivo nas teorias linguísticas e no ensino de língua portuguesa}

Soares (1998) assevera que, até meados do século XVIII, o sistema de ensino do Brasil restringia-se à alfabetização, apenas poucos alunos - os das camadas mais elitizadas da sociedade - tinham acesso à aprendizagem da língua latina, da retórica e da poética, por meio de gramáticas e antologias.

Nas últimas décadas do século XIX, o ensino acompanhou as concepções de linguagem vigentes na época. Nos anos 60, a língua era entendida como sistema reconhecimento das normas e regras - refletia-se, aqui, as tendências estruturalistas. Já nas décadas de 70 e 80, o referencial da Teoria da Comunicação subsidiou uma nova concepção de língua, como instrumento de comunicação. Conforme assinala Soares (1998, p.57),

[...] os objetivos são, agora, pragmáticos e utilitários: trata-se de desenvolver e aperfeiçoar os comportamentos do aluno como emissor-codificador e como recebedor-decodificador de mensagens, pela utilização e compreensão de códigos diversos - verbais e não-verbais. Ou seja: já não se trata mais de levar ao conhecimento do sistema linguístico - ao saber a respeito da língua - mas ao desenvolvimento de habilidades de expressão e compreensão de mensagens (grifos da autora). 
Em 1971, especialmente com a sanção da Lei de Diretrizes e Bases da Educação (5672/71), firma-se o processo de democratização de acesso da população à escola, em consequência do novo modelo econômico ${ }^{4}$. Segundo Soares (1998), nesse período, os manuais didáticos traziam não só textos literários, mas também outros textos, de esferas diversas: informativos, jornalísticos, publicitários. Havia, por um lado, o desprestígio do ensino da gramática e, por outro, a ênfase dada aos textos. O texto passa, nesse momento, a constituir a unidade de ensino de língua. Mas, como observa Rojo (2007, p.12), "a história se repete" e as práticas didáticas consolidadas (gramática) apresentam resistência e o texto entra na sala de aula menos como produtor de sentidos e mais como suporte de análises gramaticais ${ }^{5}$.

É na década seguinte que o conceito de gênero encontra sua época. As mudanças sociais e culturais impactam na escola e no currículo, multiplicando as propostas de tratamento do texto, "o volume de informações, produzido em decorrência da globalização e das novas tecnologias, é constantemente superado, colocando novos parâmetros para a formação dos cidadãos" (ROJO, 2008, p.90). Com isso, os textos não podem mais ser vistos e descritos apenas como formas da língua, é requerida uma nova concepção de língua em uso. Esse novo quadro teórico da linguagem sugere, pois, a ênfase no contexto, na relação imprescindível do texto com a situação comunicativa que o engendra. Assim, diferentes teorias do texto e do discurso passam a favorecer os estudos de práticas plurais e multimodais, como é o caso dos gêneros.

Dessa maneira, a reorientação do ensino de língua, no Brasil, decorre do que Rojo (2007) denominou, nos estudos linguísticos, de "virada discursiva". A década de 90 foi marcada pela influência e confluência de correntes linguísticas voltadas ao discurso, quais sejam: Análise da Conversação, Análise do Discurso de linha francesa, Análise Crítica do Discurso e Teorias da Enunciação. Nesse sentido, a autora destaca que:

\footnotetext{
4 "Com a ditadura militar, a partir de 1964, passa-se a buscar o desenvolvimento do capitalismo, mediante a expansão industrial. A proposta educacional, agora, passa a ser condizente com a expectativa de se atribuir à escola o papel de fornecer recursos humanos que permitiam ao Governo realizar a pretendida expansão industrial" (ROJO, 2008, p.86).

${ }^{5}$ Ressaltamos, aqui, a obra de referência de Geraldi (2011[1984]), O texto na sala de aula, que problematizou a questão, ao apontar o texto (e não a ortografia, a gramática, a sentença, ou as figuras) como a principal unidade de trabalho do professor de português em sala de aula e alertou, também, que o texto não deveria servir de pretexto para o ensino das formas da língua, mas que deveria penetrar na sala de aula como objeto de práticas de leitura e produção. Segundo Rojo (2008, p.89, grifos da autora), reflexões como estas contribuíram muito "para as mudanças nos programas e currículos de língua, nas décadas de 1970 a 1990, que, de centrados nos conteúdos (gramaticais), passam a se caracterizar como centrados em procedimentos.
} 
Os objetivos dos currículos estão voltados às competências e capacidades de leitura e escrita e de fala/escuta, mas os gêneros - em lugar dos tipos de textos (narração, descrição, dissertação, argumentação), tão presentes em décadas anteriores - aparecem como os objetos capazes de desenvolvê-las. Todos os referenciais enfocam a linguagem e a língua em uso, por meio de práticas situadas para a cidadania, o que por si só já convoca as noções de texto, gênero e discurso (ROJO, 2008, p.77, grifos da autora).

Conforme salienta Gomes-Santos (2003), há um deslocamento de uma abordagem linguística circunscrita à descrição de fatos linguísticos do nível da palavra e da sentença para outra fundamentalmente marcada pelo conceito de discurso. Nessa conjuntura intelectual, em 1997/1998, os Parâmetros Curriculares Nacionais (PCN) para disciplina Língua Portuguesa, publicados pela Secretaria de Educação Fundamental (SEF) do Ministério da Educação e do Desporto (MEC), convocam a noção de gênero como objeto de ensino de língua materna:

Os textos organizam-se no bojo de certas restrições de natureza "temática, composicional e estilística, que os caracterizam como pertencentes a este ou aquele gênero. [...] a noção de gênero, constitutiva do texto, precisa ser tomada como objeto de ensino (BRASIL, 1998, p.23, grifo nosso).

Machado, Cristóvão e Guimarães (2009, p.26) assinalam que a proposta de ensino de gêneros, evocada pelos PCN para o ensino de língua portuguesa "foi decisiva para o desenvolvimento de um número incalculável de pesquisas e de publicações sobre a questão dos gêneros, tanto sob o ponto de vista teórico quanto didático".

Nessa direção, destacamos a contribuição de Gomes-Santos (2004) que estabelece um recorte metodológico ao eleger os corpora de sua investigação: cento e cinquenta e sete (157) artigos que tematizam o conceito de gênero, publicados no período entre 1998 e 2002, e os PCN. Ao observar este material, verifica a imbricação de dois domínios institucionais pelos quais o conceito tem circulado e pelos quais, também, tem-se tornado visível: a teorização acadêmico-científica e a normatização oficial; em ambos os casos, o conceito de gênero passa por um processo de reenunciação. $\mathrm{O}$ autor constata que a discussão sobre gênero se mostra bastante expressiva no Brasil, já que atravessa modos diversos de publicação, pertencimentos teórico-disciplinares também diversos, diferentes enfoques temáticos e tipos de dados. Nos 
termos do autor, "o caráter plural com que se apresenta a reflexão sobre gênero é, na verdade, constitutivamente investido de um efeito de conciliação necessário para legitimar a questão do gênero como pertinente" (GOMES-SANTOS, 2004, p.68).

As discussões nos estudos linguísticos permitem, assim, a emergência do conceito e lhe dá sustentação e condição de circulação nos referenciais curriculares e livros didáticos (que ecoam o discurso sobre o ensino), os quais passam a produzir, em seus processos de didatização, objetos transdisciplinares complexos. Desse modo, o conceito de gênero é ressignificado, conforme assinala Rojo (2008, p.94-95):

Ao se apropriarem do conceito de gênero de discurso do Círculo de Bakhtin para efeitos de didatização, os PCN realizam tanto uma operação de desarticulação do conceito de seu espaço de sentido original, como uma rearticulação do conceito com outros já presentes nesta esfera de comunicação escolar (documentos educacionais oficiais, teorias da didática de língua materna), que dão gênese a um novo conceito e não somente a um novo uso do conceito (grifos da autora).

Quanto à discussão e divulgação do conceito nos estudos linguísticos, Marcuschi (2010) é referência primordial. Revela-se, de modo bastante proeminente, seu investimento teórico que aponta o trabalho com o texto na base dos gêneros, sejam eles orais ou escritos. Na retomada do pensamento bakhtiniano, Marcuschi (2010, p.38) postula que a relevância maior de tratar os gêneros "acha-se particularmente situada no campo da Linguística Aplicada (LA). De modo especial no ensino de língua, já que se ensina a produzir textos e não a produzir enunciados soltos".

Conforme também observa Gomes-Santos (2004), o conceito aparece como pertinente para estudos explicitamente ligados à área de LA e para os estudos que, embora mais ligados ao que se convencionou chamar, "de modo mais ou menos indistinto, de linguística do texto, do discurso, da enunciação - manifestam algum tipo de preocupação de ordem didáticopedagógica" (GOMES-SANTOS, 2004, p.136).

Há pelo menos quinze anos o conceito de gênero discursivo vem sendo incorporado a diversas circunstâncias que envolvem o ensino de língua portuguesa, como, por exemplo, a reeditoração de livros didáticos, as publicações acadêmico-científicas (artigos em anais de 
congressos ${ }^{6}$, coletâneas temáticas, dissertações e teses), a reformulação da grade curricular de cursos de graduação na área de Letras, a eleição de gêneros em processos seletivos, como o vestibular $^{7}$, e a criação de cursos de formação continuada sob este enfoque teóricometodológico.

Parece-nos, assim, que o conceito de gênero passa a servir ao discurso didáticopedagógico, do mesmo modo que o próprio discurso didático-pedagógico começa a convocálo e a elegê-lo como pertinente para o ensino de língua portuguesa. A nosso ver, tal encontro dá-se na medida em que o conceito de gênero atende ao princípio da heterogeneidade da produção discursiva, isto é, da pluralidade do uso da linguagem, de suas possibilidades e de sua dinamicidade; tal posicionamento acompanha, por assim dizer, uma concepção de texto como lugar de interação (KOCH; ELIAS, 2012).

Em outras palavras, as formas da comunicação humana são renovadas na interação e seguem a temporalidade da sociedade, conforme a ampliação dos meios de circulação de sentidos, que se valem, por exemplo, da natureza multissemiótica dos textos. Seguindo esse percurso evolutivo, em uma espécie de desafio, é esperado que a escola passe a lidar com a didatização dessas práticas, desses novos objetos de ensino. Se tais práticas nos fazem comunicar, agir e interagir, elas merecem, também, ser atualizadas e ressignificadas no contexto do ensino e aprendizagem de língua materna.

A esse respeito, destacamos a perspectiva didática desenvolvida pelos pesquisadores genebrinos, os quais apresentam uma proposta metodológica e aplicam-na, no contexto de ensino de língua francesa, em escolas públicas. O trabalho desses autores torna-se referência para pesquisas interessadas em adaptar ou reinventar tal procedimento em outras situações de ensino. Para Gomes-Santos (2004, p.83-84),

A alta frequência, por exemplo, de dados de natureza escolar ou didáticopedagógica no conjunto dos trabalhos parece coerente com o significativo número de trabalhos que têm com enfoque temático a problematização de questões de ordem didático-pedagógica. Os estudos genebrinos e estudos

\footnotetext{
${ }^{6}$ Destacamos, para ficar apenas neste exemplo, os inúmeros trabalhos inscritos nas sete edições do Simpósio Internacional de Estudos de Gêneros Textuais (SIGET), que confirmam a pluralidade de perspectivas teóricoanalíticas, que tomam o gênero discursivo/textual como foco de investigação.

${ }^{7}$ Desde 2008, o vestibular da Universidade Estadual de Maringá (UEM), por exemplo, na prova de redação, não solicita a escrita de tipologias textuais (narração e dissertação), com base em determinado tema; o candidato deve, agora, escrever pelo menos dois gêneros. Disponível em: http://www.cvu.uem.br.
} 
brasileiros de tendência similar comparecem de modo particularmente significativo na contemplação desse enfoque temático e desse tipo de dados.

A próxima seção dedica-se a apresentar a proposta metodológica dos pesquisadores genebrinos que nos ajudam a pensar os gêneros como objeto de ensino de língua portuguesa, posição também assumida por nós neste trabalho.

\subsection{A vertente didática dos gêneros: contribuições do Grupo da Universidade de Genebra}

Imbuídos da filiação didático-pedagógica concebida pelos pesquisadores genebrinos, entendemos os gêneros como megainstrumentos para agir linguisticamente em contextos de aprendizagem, especialmente, por confiar que eles facilitam, viabilizam e fundam a possibilidade de comunicação.

Esta investigação sustenta-se na vertente didática da pesquisa sobre gênero, conforme Dolz e Schneuwly (2004, p.44), para quem "o trabalho escolar, no domínio da produção de linguagem, faz-se sobre os gêneros, quer se queira ou não”. Segundo os autores, do ponto de vista do uso e da aprendizagem, o gênero pode ser considerado um megainstrumento que fornece um suporte para a atividade, nas situações de comunicação, e uma referência para os aprendizes.

Dolz, Noverraz e Schneuwly (2004, p.81-82) propuseram uma abordagem do ensino de produção escrita e de produção oral, com base nos gêneros discursivos, de forma a:

- permitir o ensino da oralidade e da escrita a partir de um encaminhamento, a um só tempo, semelhante e diferenciado;

- propor uma concepção que englobe o conjunto da escolaridade obrigatória;

- centrar-se, de fato, nas dimensões textuais da expressão oral e escrita;

- oferecer um material rico em textos de referência, escritos e orais, nos quais os alunos possam inspirar-se para suas produções;

- ser modular, para permitir uma diferenciação do ensino;

- favorecer a elaboração de projetos de classe. 
Diante disso, para o ensino de língua, os autores elegem o gênero como ponto de referência concreto aos alunos. Assim, no contexto escolar, o gênero assume uma dupla função, ele é a um só tempo gênero a aprender e gênero a comunicar. Segundo Dolz, Noverraz e Schneuwly (2004, p.82), constitui-se dever da escola criar contextos de produção precisos, efetuar atividades ou exercícios diversos, é isso que permitirá aos alunos "apropriarem-se das noções, das técnicas e dos instrumentos necessários ao desenvolvimento de suas capacidades de expressão oral e escrita, em situações de comunicação diversas".

Nesta perspectiva, a introdução de um gênero na escola resulta de uma decisão didática que visa a objetivos precisos de aprendizagem: aprender a dominar um gênero para melhor conhecê-lo ou apreciá-lo, para melhor saber compreendê-lo, para melhor produzi-lo na escola ou fora dela. Dolz, Schneuwly e Haller (2004, p.144) salientam que o trabalho com os gêneros em sala de aula oferece um quadro de condições efetivas para a produção e a recepção de textos, no que respeita à "análise dos conteúdos, da organização do conjunto do texto e das sequências que o compõem".

A contribuição dos pesquisadores genebrinos deve-se, em grande medida, ao procedimento intitulado "sequência didática", que pode ser entendido, nos termos dos autores, como um conjunto de atividades escolares organizadas, de maneira sistemática, em torno de um gênero discursivo oral ou escrito, que busca confrontar os alunos com práticas de linguagem historicamente construídas, para lhes dar a possibilidade de reconstruí-las e delas se apropriarem. Em outras palavras, as sequências didáticas são módulos de ensino, organizados conjuntamente para melhorar uma determinada prática de linguagem, e podem guiar, de modo significativo, as intervenções dos professores e, consequentemente, ajudar o aluno a dominar melhor um gênero, "permitindo-lhe, assim, escrever ou falar de uma maneira mais adequada numa dada situação de comunicação ${ }^{8 \%}$ (DOLZ; NOVERRAZ; SCHNEUWLY, 2004, p.83).

\footnotetext{
${ }^{8}$ Parece-nos importante destacar o investimento teórico dos pesquisadores genebrinos, no que diz respeito à construção de modelos didáticos de gêneros, que fornecem objetos potenciais para o ensino, ao articular quatro conjuntos de dados, a saber: as práticas sociais de referência, a literatura a respeito do gênero, as práticas de linguagem dos alunos e as práticas escolares. Segundo Pietro e Schneuwly (2014, p.67), o modelo didático permite a um só tempo construir, para um mesmo público-alvo, "diferentes atividades de ensino/aprendizagem e construir sequências de ensino/aprendizagem de complexidade crescente, segundo o desenvolvimento dos alunos".
} 
Desenvolvida no contexto francófono, a proposta foi vastamente assimilada por pesquisadores brasileiros e vem sendo retomada de diversas maneiras. Apresentamos, a seguir, alguns desdobramentos desses estudos.

\subsubsection{Desdobramentos dos estudos genebrinos no Brasil}

Para Nascimento (2009), as sequências didáticas são "os dispositivos de organização dos conteúdos a serem didatizados sobre uma prática de referência”. Machado e Cristóvão (2009) afirmam que as sequências didáticas são atividades progressivas, planificadas, guiadas ou por um tema, ou por um objetivo geral, ou por uma produção de texto final e possibilitam o trabalho com práticas de escrita, de leitura e práticas orais. Ao recuperar a contribuição do trabalho desenvolvido pelo Grupo da Universidade de Genebra, Marcuschi (2008, p.214) considera o fato de "a finalidade de trabalhar com sequências didáticas é proporcionar ao aluno um procedimento de realizar todas as tarefas e etapas para a produção de um gênero".

A partir da releitura do procedimento proposto por Dolz, Noverraz e Schneuwly (2004), ao longo de quase uma década - a contar da publicação da tradução brasileira da obra desses autores, especificamente - inúmeros trabalhos de ordem didático-pedagógica vêm sendo elaborados por pesquisadores de diversas universidades brasileiras, problematizando, sobretudo, situações que sinalizam para questão que nos inquieta. Corrobora esta posição o que afirma Gomes-Santos (2004, p.86):

[...] a relevância da instituição escolar como espaço privilegiado para a investigação da questão do gênero, seja como contexto-inicial que instiga as indagações para a pesquisa, seja como contexto-alvo em que se busca intervir com propostas didáticas ditas inovadoras, entre outras possibilidades.

Nessa direção, destacamos o trabalho de Costa-Hübes e Simioni (2014), o qual discute a produção do Currículo Básico para Escola Pública Municipal da Região Oeste do Paraná, publicado em 2007, que adotou em sua concepção a proposta metodológica da sequência didática elaborada pelos autores suíços, readequando-a, porém, de modo a adaptá-la para o 
ensino de escolas públicas brasileiras ${ }^{9}$. De acordo com as autoras, os estudos genebrinos recobrem uma realidade estrangeira e foram pensados para alunos da Suíça, país cujas condições relacionadas à educação diferem do contexto brasileiro, conforme indicam as autoras:

No sistema suíço, todos os anos de ensino possuem uma grade curricular que contempla uma disciplina com aulas semanais específicas só para produção textual, para a qual essa metodologia - Língua Portuguesa - para trabalhar com os eixos da oralidade, da leitura, da produção escrita, da análise linguística/reescrita do texto (COSTA-HÜBES; SIMIONI, 2014, p.25).

Projetos pedagógicos que visam, sobretudo, à produção escrita de gêneros são notavelmente presentes em Lopes-Rossi (2002a, 2002c). Os trabalhos relatados nestes textos são resultados de pesquisas-ação, sob orientação da docente, realizados, em sua maioria, nas escolas da rede pública e particular de ensino do Vale do Paraíba, em São Paulo. Tais estudos focalizam, especialmente, a formulação de sequências didáticas que possibilitam aos alunos, segundo a autora (2012, p.238), "conhecer o gênero e se apropriar de suas dimensões ensináveis e, ainda, produzi-lo no âmbito de um projeto elaborado com esse objetivo".

Guimarães, Campani-Castilhos e Drey (2008) organizaram um livro teórico-prático intitulado Gêneros de texto no dia-a-dia do ensino fundamental ${ }^{10}$. Com esta proposta, as autoras buscam dialogar diretamente com os professores de língua e oferecer sugestões de como trabalhar, em sala de aula, diferentes gêneros discursivos, a fim de que o professor possa auxiliar seus alunos no desenvolvimento de competências relacionadas à leitura e à produção de textos pertencentes a esses gêneros.

Poderíamos, assim, seguir apresentando inúmeros exemplos de trabalhos que se manifestam como contribuições efetivas para o ensino de gêneros discursivos, tendo em vista o número incontável de publicações que privilegiam a aplicação de sequências didáticas, no

\footnotetext{
${ }^{9}$ Ao adaptarem a proposta do Grupo da Universidade de Genebra ao contexto de ensino brasileiro, Costa-Hübes e Simioni (2014, p.37) indicam seis etapas que envolvem a proposta metodológica da sequência didática: "1. Apresentação da situação de comunicação; 2.Seleção do gênero discursivo/textual; 3.Reconhecimento do gênero (por meio de pesquisa, leitura e análise linguística); 4.Produção oral ou escrita; 5.Reescrita do texto (no caso do texto escrito); 6. Circulação do gênero".

${ }^{10}$ Esta obra apresenta atividades voltadas para a escrita dos gêneros: conto humorístico infantil, peça teatral infantil e diário pessoal. O livro é resultado de sequências didáticas desenvolvidas pelas autoras e aplicadas à sala de aula; é fruto, também, de pesquisas acadêmicas no contexto de pós-graduação.
} 
âmbito da leitura, da produção escrita e da produção oral. Caracterizadas, em sua maioria, como pesquisas-ação, as produções científicas nas universidades brasileiras ${ }^{11}$, que priorizam a perspectiva didática, revelam-se primordiais, na medida em que procuram contribuir, efetivamente, com a prática de sala de aula. Nesse sentido, como explicita Matêncio (2007, p.61), entendemos que

[...] procedimentos de ensino e de aprendizagem que incluam textos em situações efetivas de produção, recepção e circulação e focalizem a relação entre ações de linguagem e atividade de interação são o melhor caminho para que o aluno compreenda as razões de os sujeitos fazerem o que fazem nas práticas sociodiscursivas.

Disso, depreendemos que é por meio dos gêneros que as práticas de linguagem incorporam-se às atividades dos alunos; nos processos de ensino e aprendizagem de gêneros discursivos, os projetos pedagógicos se apresentam como uma opção adequada (LOPESROSSI, 2011), conforme faremos observar.

\subsubsection{Projetos pedagógicos em torno da produção de gêneros discursivos}

O referencial curricular para disciplina Língua Portuguesa indica que o trabalho com projetos em sala de aula apresenta um objetivo compartilhado por professor, alunos e, de certa forma, por toda comunidade escolar, que se desenvolve em função de uma produção final, da qual todos trabalham e que terá, necessariamente, destinação, divulgação e circulação social na escola ou fora dela. Em outras palavras,

\footnotetext{
11 Destacamos, nesse sentido, o Grupo de Pesquisa Análise de Linguagem, Trabalho Educacional e suas Relações (ALTER), coordenado pelas professoras Lousada (USP) e Guimarães (UNISINOS), que desde 2002 congrega pesquisadores voltados, especialmente, para o desenvolvimento da teoria do Interacionismo Sociodiscursivo (ISD); e o Grupo de Pesquisa Gêneros textuais e mediações formativas (GEMFOR), coordenado pelas professoras Nascimento e Saito (UEL), que desde 2010 promove, por exemplo, a elaboração de sequências didáticas que envolvem o trabalho nos eixos do uso (leitura, escuta e produção) e da reflexão (análise linguística), aplicando-as em contextos de ensino e aprendizagem variados (Disponível em: http://lattes.cnpq.br/web/dgp).
} 
São situações em que as atividades de escuta, leitura e produção de textos orais e escritos, bem como as de análise linguística se inter-relacionam de forma contextualizada, pois quase sempre envolvem tarefas que articulam essas diferentes práticas, nas quais faz sentido, por exemplo, ler para escrever, escrever para ler, decorar para representar ou recitar, escrever para não esquecer, ler em voz alta, falar para analisar depois etc. (BRASIL, 1998, p.87).

$\mathrm{Na}$ conjuntura atual, estudiosos brasileiros têm-se debruçado na discussão de questões dessa ordem. Cristóvão e Nascimento (2011) assinalam que é papel da escola proporcionar aos alunos condições para que se domine o funcionamento textual com vistas a sua inserção social. Rojo (2007) também atribui à escola a responsabilidade de viabilizar propostas de letramentos críticos e protagonistas. Nessa direção, Hila (2009, p.160-161) elege o professor de língua materna como gerador de oportunidades para os alunos "se apropriarem das características discursivas e linguísticas dos mais variados gêneros textuais, inseridos em práticas reais contextualizadas, de modo a fazê-los letrados".

Para Lopes-Rossi (2011, p.71), isto pode ser feito com muita eficiência por meio de projetos pedagógicos "que visem ao conhecimento, à leitura, à discussão sobre o uso e as funções sociais dos gêneros escolhidos e, quando pertinente, a sua produção escrita e circulação social". Segundo a autora, o objetivo geral de um projeto com gêneros fundamentase no desenvolvimento da competência comunicativa do aluno, pela compreensão das características típicas do gênero em estudo.

Conforme salientam Saito e Nascimento (2005), em projetos pedagógicos em torno de um gênero, é de fundamental importância que os alunos conheçam as características do projeto para aderirem a ele e participarem, de fato. Nesse sentido, as estratégias de ensino devem implicar a busca de intervenções que favoreçam a apreensão dos gêneros e das situações de comunicação que lhes correspondem, "levando os alunos a progredirem naquilo que eles já sabem em relação ao gênero decompondo em forma de atividades tudo aquilo que eles ainda não estão aptos a realizar sozinhos" (SAITO; NASCIMENTO, 2005, p.28).

Para tanto, Lopes-Rossi (2002b) sugere etapas que envolvem o desenvolvimento de projetos pedagógicos voltado, especialmente, para produção escrita de gêneros. São elas: 
1. conhecimento das características típicas do gênero a ser produzido, por meio de uma primeira etapa de leitura de vários exemplos do gênero e discussões ou atividades que levem os alunos à apropriação de suas características discursivas e lingüístico-textuais;

2. organização dos alunos, preferencialmente em grupos, para a produção escrita visando ao objetivo final proposto;

3. planejamento para obtenção das informações necessárias de acordo com as condições reais de produção do gênero - os alunos devem agir como aqueles que normalmente produzem o gênero em estudo;

4. elaboração da primeira versão do texto - dependendo do gênero, pode incluir texto não verbal e planejamento gráfico específico;

5. revisão colaborativa - com participação de professor, alunos e até outros colaboradores - dessa primeira versão do texto;

6. elaboração de outras versões, se necessário (com revisão colaborativa);

7. divulgação ao público, de acordo com a forma típica de circulação do gênero (LOPES ROSSI, 2002b, p.144-145).

Essas orientações metodológicas para o trabalho com projetos pedagógicos foram vastamente aplicadas em trabalhos orientados pela pesquisadora ${ }^{12}$. Tais projetos seguem, em parte, os aportes teóricos do ensino modular propostos pelo Grupo da Universidade de Genebra. Lopes-Rossi $(2006,2011)$ sugere uma adaptação ao procedimento elaborado pelos pesquisadores suíços; sua proposta consiste da elaboração de três grandes Módulos Didáticos para o trabalho com a produção escrita de gêneros discursivos nas aulas de língua portuguesa.

Apresentamos, na próxima seção, a proposta da pesquisadora e assinalamos, também, nossa adaptação a esse procedimento, tendo em vista o objetivo de nossa pesquisa-ação ${ }^{13}$ : levar os alunos a experimentar os processos que envolvem a produção e a recepção ${ }^{14}$ do texto dramático.

\footnotetext{
${ }^{12}$ Sob a orientação de Lopes-Rossi, muitos projetos foram aplicados em diversos contextos de ensino e culminaram na produção de gêneros, dentre os quais: cartazes, classificados, cartões de natal, livros de poesias, livros de histórias, receitas, reportagens, propagandas sociais, críticas de filmes, críticas de CDs, notícias de rádio, paródias etc.

${ }^{13}$ A aplicação desta proposta é explicitada no Capítulo V deste trabalho.

${ }^{14}$ É válido pontuar que a referência à palavra recepção, ao longo deste trabalho, pressupõe a noção de produção; não se trata, portanto, de uma recepção passiva, pelo contrário, entendemos, assim como Koch (2007), a linguagem como o lugar de interação, de constituição de identidades, de representação de papéis, de negociação de sentidos, em uma palavra: de co-enunciação.
} 


\subsubsection{Módulos Didáticos para o ensino de gêneros discursivos: posição metodológica}

Para os autores genebrinos (2004), a modularidade se constitui princípio geral no uso das sequências didáticas, compreendendo processos de observação e descoberta; ao realizar os módulos, os alunos aprendem também a falar sobre o gênero abordado, "eles adquirem um vocabulário, uma linguagem técnica, que será comum à classe e ao professor. [...] Eles constroem progressivamente conhecimentos sobre o gênero" (DOLZ; NOVERRAZ; SCHNEUWLY, 2004, p.89, grifo dos autores)

Com efeito, Lopes-Rossi, em seus trabalhos de 2002, 2006 e 2011, recupera o procedimento originalmente atribuído ao Grupo da Universidade de Genebra, e o reformula, considerando necessário, antes da primeira produção escrita, um módulo de leitura para apreensão das características típicas do gênero. Conforme destaca a autora (2011, p.72), “[...] a leitura dos gêneros na escola nem sempre pressupõe a escrita. Esta, no entanto, pressupõe sempre atividades de leitura para que os alunos se apropriem das características dos gêneros que produzirão".

A autora também indica um terceiro módulo de circulação do gênero produzido (posterior ao módulo de produção escrita) e enfatiza a importância da divulgação ao público, já que "a escolha do gênero a ser produzido na escola deve ser determinada por oportunidades de divulgação da produção dos alunos" (LOPES-ROSSI, 2002b, p.138).

No conjunto de sua obra, a pesquisadora apresenta três grandes Módulos para o trabalho de transposição didática de gêneros discursivos da escrita, a saber: Módulo 1 Leitura do gênero, Módulo 2 - Produção escrita e Módulo 3 - Divulgação ao público (circulação do gênero). Da leitura de seus trabalhos, depreendemos o Esquema 1, a seguir:

Esquema 1 - Módulos Didáticos propostos pela pesquisadora Lopes-Rossi (2002, 2006 e 2011)

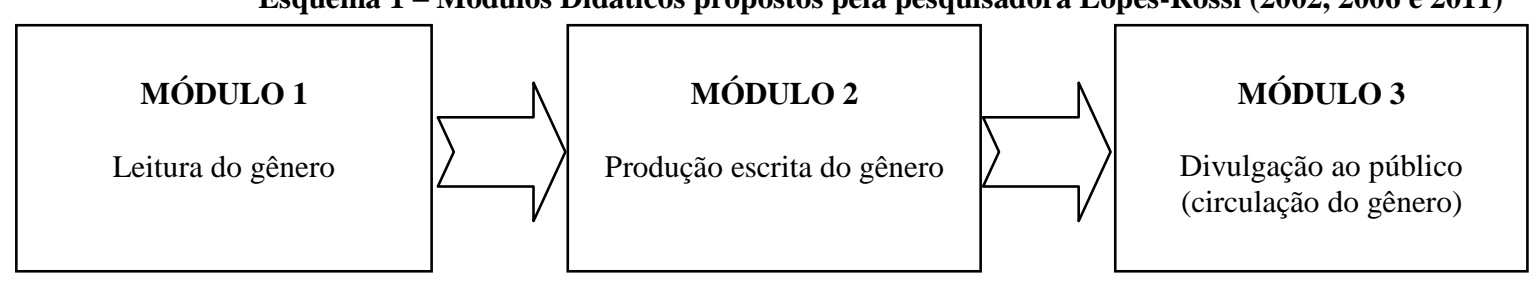


Elegemos para nossa pesquisa o encaminhamento metodológico desenvolvido pela autora, tendo em vista o fato de ajustar-se a nossa proposta de produção escrita do texto dramático. Em razão da natureza multimodal de nosso objeto de estudo, inserimos outros dois Módulos à proposta de Lopes-Rossi (2002, 2006 e 2011). O primeiro consiste da retomada do que Dolz, Noverraz e Schneuwly (2004) denominam "apresentação da situação”. Em nossa proposta, nomeamos este primeiro módulo de "Presentificação do Objeto de Ensino", o qual antecederia o módulo de leitura, responsável por marcar o momento inicial de sensibilização e contextualização do projeto pedagógico em torno de um gênero discursivo, em nosso caso, corresponderia ao engajamento dos alunos na esfera teatral. O segundo módulo recobre o interesse desta pesquisa pela produção oral e multimodal do gênero texto dramático; por essa razão, sugerimos a inserção, também, desse tipo de produção após a escrita do gênero.

A partir dessas considerações, os procedimentos metodológicos que caracterizam e sustentam a proposta de pesquisa-ação deste trabalho apresentam-se em cinco (05) Módulos Didáticos, dispostos no Esquema 2, a seguir:

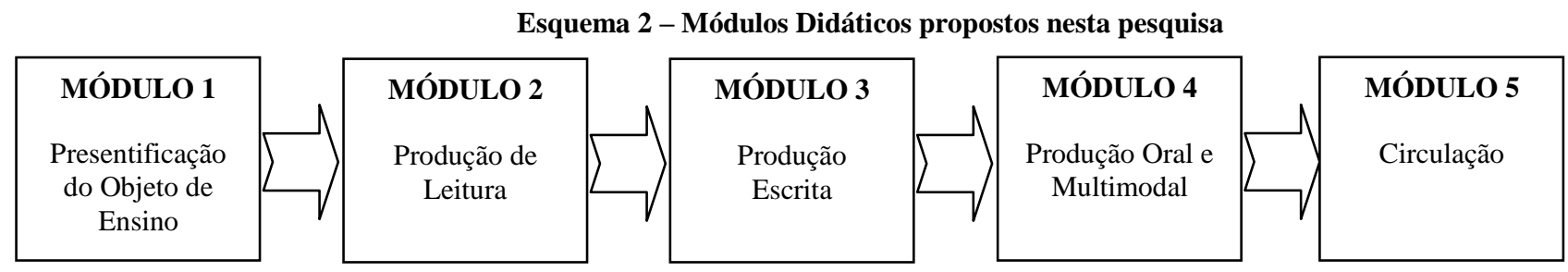

Nas próximas seções deste capítulo, buscamos discutir cada um desses Módulos Didáticos. Para apresentação do Módulo 1 - Presentificação do Objeto de Ensino, recorremos aos postulados do Grupo da Universidade de Genebra quanto à indicação da "apresentação da situação" e às pesquisas brasileiras de Nascimento (2009) e de Machado e Cristóvão (2009), que sinalizam a importância do envolvimento dos alunos no início de projetos pedagógicos para produção de gêneros. 


\subsubsection{Módulo 1 - Presentificação do Objeto de Ensino}

Dolz, Noverraz e Schneuwly (2004) assinalam a "apresentação da situação" como um momento de esclarecimento para os alunos sobre os objetivos visados e do itinerário a percorrer para atingi-los. É o momento de apresentação do projeto de produção de um gênero escrito/oral e de levá-los a responder às indagações: Qual gênero será abordado? A quem se dirige essa produção (público-alvo)? Que forma assumirá a produção? Quem participará da produção? Para os autores (2004, p.85), a fase inicial de apresentação da situação fornece aos alunos "as informações necessárias para que conheçam o projeto comunicativo visado e a aprendizagem de linguagem a que está relacionado”.

Essa afirmação permite-nos inferir que é o professor quem deve apresentar o projeto ao aluno e, de certa forma, inseri-lo (e por que não cativá-lo?) em seu contexto de produção, pois, como aponta Nascimento (2009), a fase inicial da sequência didática é de importância crucial na implantação do projeto de classe, pois corresponde à fase da conquista dos alunos para o empreendimento no qual deverão agir de forma ativa e cooperativa.

Nessa direção, Machado e Cristóvão (2009, p.128) postulam que, "no ensino de gêneros, se os aprendizes não sentirem necessidade de um determinado gênero para seu agir verbal, haverá muito maior dificuldade para sua apropriação". Assim, se o aluno tiver conhecimento, desde o início do projeto, do quê irá fazer, o professor poderá ter maior facilidade para criar subsídios e ensinar como fazer.

Schneuwly e Dolz (2004) consideram a importância de se conhecer o gênero que se pretende ensinar, pois quanto mais precisa a definição das dimensões ensináveis de um gênero, mais ela facilitará a apreensão deste como instrumento e possibilitará o desenvolvimento de capacidades de linguagem diversas que a ele estão associadas. Segundo os autores (2004, p.76), "o objeto de trabalho sendo, pelo menos em parte, descrito e explicitado, torna-se acessível a todos nas práticas de linguagem de aprendizagem".

Os pesquisadores indicam, também, que a ordem de uma sequência didática não é aleatória, pois certas atividades apresentam uma base para realização de outras. Desta maneira, a nosso ver, o Módulo Didático, por nós rotulado "Módulo 1 - Presentificação do Objeto de Ensino", pode localizar-se no início do projeto pedagógico, no sentido de oferecer 
aos alunos atividades diferenciadas, como por exemplo, assistir a um filme no cinema, ir ao teatro ou a um sarau de poesias, conhecer a redação de um jornal da cidade ou um escritório de propaganda e publicidade, fazer uma receita culinária etc.

Essas atividades parecem-nos significativas na medida em que buscam sensibilizar e motivar os alunos para a situação didática a ser instaurada. Acresce-se a isso o fato de que, no decorrer de toda sequência didática, o objeto de ensino (gênero) merece tornar-se presente e ser decomposto para que o aluno possa estudá-lo, observá-lo, analisá-lo, praticá-lo, manipulálo etc. (SCHNEUWLY, 2009).

Apresentamos, na próxima seção, as orientações de Lopes-Rossi (2002c, 2006, 2012), para o Módulo Didático que caracteriza a leitura do gênero como etapa fundamental para sua produção. Esse posicionamento é compartilhado, também, por Barros e Nascimento (2007), Hila (2009), Nascimento (2009) e Costa-Hübes e Simioni (2014).

\subsubsection{Módulo 2 - Produção de Leitura}

Apoiamo-nos em Lopes-Rossi (2002c), para quem a organização típica do gênero discursivo merece ser conhecida por quem vai produzi-lo. Nesse sentido, as características significativas de cada gênero podem ser observadas, estudadas e apreendidas pela leitura da materialidade textual, conforme salienta a autora:

\footnotetext{
Além das características linguístico-textuais típicas dos gêneros - incluindo todos os aspectos gráficos -, que podem ser observadas, estudadas e conhecidas pela [leitura/observação da] materialidade do texto e de seu suporte, há outras - as características discursivas - que não são visíveis. Estas, de modo geral, referem-se às condições de produção e de circulação do gênero na sociedade [...] (LOPES-ROSSI, 2002c, p.28).
}

Nessa direção, Hila (2009) também considera o fato de, no ensino de gêneros, a aula de leitura possibilita ao aluno observar se há ou não uma estrutura mais estável para determinado gênero, já que a identificação de tal estrutura, o ajudará no processo de recepção e de produção escrita do próprio gênero. Para a autora, a sequência de atividades propostas na 
etapa de leitura do gênero prepara o aluno para a produção escrita, no sentido de dotá-lo de conhecimento, ainda que básico, sobre o gênero em estudo.

Lopes-Rossi (2012) enfatiza que o módulo de leitura tem por finalidade levar o aluno a discutir, comentar e conhecer as condições de produção e de circulação do gênero escolhido, a partir de exemplares - gêneros de referência -, preferencialmente, originais. Nesse sentido, nos termos da autora (2012, p.240), as atividades de leitura constituem-se de um módulo “idealizado a partir do pressuposto de que o aluno ainda não conhece suficientemente bem o gênero discursivo proposto pelo professor e seria incapaz de produzi-lo adequadamente" e, por essa razão, nesse módulo, é necessário que haja atividades direcionadas às condições de produção do gênero em estudo (quem escreve, o quê escreve, para quem, por quê, quando, como etc.). Com efeito, a autora apresenta os níveis de conhecimento necessários à apreensão das características de um gênero, conforme indicamos:

a) conhecimento de suas características discursivas, temáticas e composicionais (aspectos verbais e não-verbais);

b) conhecimento das condições de produção e de circulação do gênero, com identificação da função comunicativa do gênero, da temática possível, de características discursivas;

c) conhecimento das características e elementos composicionais do gênero, identificáveis com uma leitura global dos exemplos;

d) conhecimento das características de organização do texto verbal e não-verbal do gênero, identificáveis com uma leitura mais detalhada dos exemplos, observação de como as informações se posicionam no texto verbal e como os elementos não-verbais se posicionam no suporte;

e) conhecimento de características linguísticas e de estilo do texto e, ainda, de suas marcas enunciativas, identificáveis com uma leitura mais detalhada dos exemplos (LOPES-ROSSI, 2006, p.6).

Costa-Hübes e Simioni (2014) também ressaltam a necessidade e a importância de um módulo de leitura, denominado pelas autoras "Reconhecimento do Gênero", antes da produção oral ou escrita de gêneros discursivos. Nessa etapa, incluem-se atividades de pesquisa, leitura e análise linguística, conforme salientam:

Esse módulo, acrescentado à proposta dos autores suíços, dialoga com os preceitos bakhtinianos de estudo da língua, à medida que possibilita ao aluno uma análise sociológica das condições de produção do enunciado e contribui para que se perceba elementos organizadores das sequências discursivas que 
compõem um gênero. Além disso, o módulo possibilita que o professor trabalhe, de modo mais articulado, conteúdos da língua inerentes à oralidade, à leitura e à escrita (COSTA-HÜBES; SIMIONI, 2014, p.32).

Parece-nos possível entender a relevância do módulo de leitura, principalmente, quando fundamenta um projeto pedagógico voltado para produção escrita. Nossa posição sustenta-se em Nascimento (2009, p.73), para quem a leitura e o reconhecimento de textos do gênero de referência podem propiciar "a criação de situações para favorecer a aquisição e o desenvolvimento do saber escrito, pela observação da presença desses elementos no texto que está sendo objeto de leitura".

A respeito da seleção textual adequada às atividades de tal módulo, Barros e Nascimento (2007) salientam que sua escolha não pode partir de um único texto de referência, seguida de uma proposta de produção textual, pois, dessa maneira, dificilmente se consegue abranger toda a complexidade textual, discursiva e enunciativa de determinado gênero.

Do mesmo modo, Costa-Hübes e Simioni (2014) observam que, na tentativa de facilitar a compreensão do gênero discursivo a ser trabalho em sala de aula, o professor pode sugerir a leitura de textos disponíveis na sociedade, os quais circulam em diferentes esferas. As autoras esclarecem, no entanto, que:

Ao se propor um olhar para textos já publicados, não se pretende, com isso, retornar às práticas tradicionais e mecânicas de simplesmente "seguir o modelo". O que se quer, realmente, é que o aluno, antes de produzir um texto de determinado gênero, reconheça-o quanto à sua função social, ao meio de produção e circulação, à sua construção composicional e ao seu estilo (COSTA-HÜBES; SIMIONI, 2014, p.29).

Cabe destacar, ainda, que o módulo de leitura permite ao professor reconhecer o que o aluno sabe a respeito do gênero e o que ele não sabe, de forma a antecipar o levantamento de dificuldades a serem superadas, e as novas atividades a serem adicionadas à sequência didática em torno do gênero proposto (NASCIMENTO, 2009, p.73). Nessa direção, seus estudos e aqueles anteriormente mencionados, fortalecem nossa proposta de consideramos, 
em nossa pesquisa, o Módulo 2 - Produção de Leitura voltado, especificamente, para apreensão das características do gênero ${ }^{15}$.

Apresentamos, a seguir, o módulo que corresponde à produção escrita de gêneros discursivos, etapa minuciosamente detalhada nos trabalhos de Lopes-Rossi (2011, 2012).

\subsubsection{Módulo 3 - Produção Escrita}

Ao apreender as características típicas do gênero no módulo de leitura, entendemos que o aluno tenha iniciado um processo que lhe dê condições mais adequadas para escrever um gênero discursivo, selecionando, assim, o tema, a estrutura composicional e o estilo que se ajustam à atividade proposta.

Segundo Lope-Rossi (2002a), na perspectiva didática, os procedimentos que envolvem a produção escrita de um gênero discursivo demandam certo tempo (escolar), pois requerem o desenvolvimento de inúmeras atividades no módulo de leitura que solidificam o estudo de um gênero discursivo e preparam o aluno para a produção escrita. Para a autora (2012), trata-se da apreensão de conhecimentos específicos do gênero em estudo, os quais transcrevemos no Quadro 1, a seguir:

\footnotetext{
${ }^{15}$ Entendemos que esta proposta não exclui (nem tampouco invalida) o trabalho voltado para a interpretação e a compreensão do texto, que tem como estratégias de leitura fundamentais a predição, a seletividade e a inferência (BRITO, 2002).
} 
Quadro 1 - Conhecimentos específicos necessários à produção de gêneros discursivos

Lopes-Rossi (2012, p.236-7)

\begin{tabular}{|c|c|c|c|}
\hline \multicolumn{2}{|c|}{ Níveis de conhecimento } & $\begin{array}{c}\text { Informações que } \\
\text { proporcionam para a } \\
\text { produção }\end{array}$ & $\begin{array}{l}\text { Perguntas básicas } \\
\text { orientadoras para obter essas } \\
\text { informações } \\
\text { (construir o modelo didático) } \\
\text { Com que finalidade se produz } \\
\text { esse gênero? }\end{array}$ \\
\hline $\begin{array}{l}\text { Específicos para cada } \\
\text { gênero discursivo }\end{array}$ & $\begin{array}{l}\text { Aspectos } \\
\text { sociocomunicativos: } \\
\text { Propósito } \\
\text { comunicativo } \\
\text { Temática } \\
\text { Estilo } \\
\text { Condições de } \\
\text { produção, circulação e } \\
\text { recepção }\end{array}$ & $\begin{array}{l}\text { Assunto que se pode abordar } \\
\text { Finalidade da produção } \\
\text { Informações necessárias ao } \\
\text { gênero } \\
\text { Estilo que se pode utilizar em } \\
\text { função do propósito, do } \\
\text { público alvo, do meio de } \\
\text { circulação do texto } \\
\text { Onde e como obter } \\
\text { informações para a produção } \\
\text { escrita, como o fazem } \\
\text { autores proficientes }\end{array}$ & $\begin{array}{l}\text { Com que finalidade se produz } \\
\text { esse gênero? } \\
\text { Quem escreve (em geral) esse } \\
\text { gênero discursivo? } \\
\text { Onde? Quando? Com base em } \\
\text { que informações? } \\
\text { Como o redator obtém as } \\
\text { informações? } \\
\text { Qual o nível de formalidade do } \\
\text { gênero? } \\
\text { Apresenta vocabulário técnico } \\
\text { ou específico? } \\
\text { Quem lê esse gênero? Porque o } \\
\text { faz (com que objetivos o lê)? } \\
\text { Onde o encontra? } \\
\text { Que tipo de resposta pode dar } \\
\text { ao texto? } \\
\text { Que influência pode sofrer } \\
\text { devido a essa leitura? }\end{array}$ \\
\hline & $\begin{array}{l}\text { Elementos } \\
\text { composicionais } \\
\text { verbais e não } \\
\text { verbais }\end{array}$ & $\begin{array}{l}\begin{array}{l}\text { Elementos não verbais } \\
\text { possíveis (fotos, imagens, } \\
\text { infográficos, mapas, } \\
\text { ilustrações, etc.) } \\
\text { Distribuição das informações } \\
\text { verbais e não verbais no } \\
\text { suporte } \\
\text { Padrões de Diagramação } \\
\text { possíveis no gênero para os } \\
\text { elementos composicionais }\end{array}\end{array}$ & $\begin{array}{l}\text { Que elementos verbais e não } \\
\text { verbais compõem o gênero } \\
\text { discursivo } \\
\text { (título, texto, subtítulo, foto, } \\
\text { ilustração, gráfico, tabela, } \\
\text { indicações de alguma } \\
\text { informação nas margens da } \\
\text { página, cores, recursos gráficos } \\
\text { em geral, qualquer outra } \\
\text { característica que chame a } \\
\text { atenção)? } \\
\text { Como se posicionam no suporte } \\
\text { e como aparecem diagramados? }\end{array}$ \\
\hline & $\begin{array}{l}\text { Movimentos retóricos } \\
\text { esperados para o } \\
\text { gênero (se houver um } \\
\text { padrão estável) }\end{array}$ & $\begin{array}{l}\text { Como começar o texto } \\
\text { Como continuar e } \\
\text { desenvolver o } \\
\text { texto } \\
\text { Como concluir o texto } \\
\text { Possibilidades ou eventuais } \\
\text { restrições caso não haja um } \\
\text { padrão retórico estável para o } \\
\text { gênero }\end{array}$ & $\begin{array}{l}\text { Que tipo de informação se } \\
\text { espera encontrar em cada parte } \\
\text { do texto? }\end{array}$ \\
\hline
\end{tabular}


Das informações constantes do Quadro 1, depreende-se que a produção escrita de um gênero parece ser orientada por um processo que envolve sujeitos em práticas discursivas adequadas a uma interlocução viva e real. Entendemos, assim, que o conhecimento da composição do gênero discursivo - em todos os seus aspectos verbais e não-verbais - é imprescindível para sua produção escrita. Para Lopes-Rossi (2002a), a percepção dessa estrutura mais ou menos estável relaciona-se, fundamentalmente, à função social, à esfera de circulação e aos propósitos comunicativos do gênero em estudo.

Em relação aos enunciados que constam das orientações de uma proposta de produção escrita, Val (2003, p.133) assinala que o não esclarecimento de finalidades concretas faz pensar em objetivos de natureza escolar, "pressupostos e previamente aceitos por todos os envolvidos: escrever para aprender, para atender às demandas do professor, para ter nota".

Lopes-Rossi (2011) orienta, ainda, que o trabalho de produção escrita pode ser desenvolvido em pequenos grupos, favorecendo, assim, a interação, a troca de informações e a divisão de tarefas. As inúmeras versões, sequenciadas da correção colaborativa de alunos e professor, encerrariam esse módulo; neste momento o aluno passa a aprender que "escrever é (também) reescrever”, como postulam Dolz, Noverraz e Schneuwly (2004, p.95).

Em razão de conhecer no gênero discursivo texto dramático a possibilidade de sua produção oral e de compreender sua natureza multimodal ${ }^{16}$, nossa proposta prevê, também, a realização de um módulo didático que se situa após a produção escrita do gênero; dessa maneira, à nomenclatura desse novo módulo, acrescentamos a indicação “oral e multimodal”.

Essa posição encontra respaldo nos trabalhos de Rojo (2012) e Rojo e Barbosa (2015), que buscam discutir o alargamento da constituição dos textos em virtude, por exemplo, do multiculturalismo, das inovações tecnológicas e do surgimento das mídias digitais. A proposição desse módulo didático recupera, ainda, as contribuições dos pesquisadores do Grupo da Universidade de Genebra voltadas à produção de gêneros orais.

$\mathrm{Na}$ próxima seção, tratamos da importância do trabalho com a oralidade e com a multimodalidade no contexto de ensino e aprendizagem de língua, no que diz respeito à produção de gêneros discursivos que possibilitam o alargamento da dimensão do objeto de ensino: do escritural para o oral e multimodal.

\footnotetext{
${ }^{16}$ Cabe destacar que o posicionamento assumido é amplamente discutido no Capítulo II deste trabalho.
} 


\subsubsection{Módulo 4 - Produção Oral e Multimodal}

A produção de gêneros orais nos contextos de ensino e aprendizagem de língua é, ainda, pouco explorada, conforme assinalam Dolz, Schneuwly e Haller (2004, p.125), “embora a linguagem oral esteja bastante presente nas salas de aula [...] afirma-se frequentemente que ela não é ensinada, a não ser incidentalmente, durante atividades diversas e pouco controladas". Parece-nos que pelo fato de a oralidade ter uma primazia cronológica indiscutível sobre a escrita e, mais do que isso, em razão de a fala ser adquirida naturalmente em contextos informais, o aluno, ao entrar em contato com o meio escolar, não é levado a exercitar a oralidade em situações comunicativas de aprendizagem.

Quando se trata de atividades que desenvolvam aspectos da oralidade, Silva e Moride-Angelis (2003) observam que os alunos fazem uso da língua oral para responder a questões, contar uma história para classe, realizar entrevistas ou debates. No entanto, os autores (2003, p.205) avaliam que tais práticas não estão ajustadas a "práticas de reflexão sobre os usos, o que não permite compreender qual é o tipo de conhecimento sobre a linguagem oral que pode estar em construção em propostas como essas”. Soma-se a isso, o fato de que o espaço dedicado à língua falada raramente supera o percentual de $2 \%$ no cômputo geral de páginas dos livros didáticos, conforme destaca Marcuschi (2005).

Mesmo diante dessa realidade, observamos que o cenário de publicações acadêmicas em torno das possibilidades de se trabalhar com os gêneros orais em sala de aula vem ganhando destaque nos últimos anos. Os pesquisadores genebrinos realizaram um extenso trabalho em torno dos gêneros debate público e exposição oral, a partir da aplicação de seus procedimentos metodológicos - sequência didática - sob o mote "o oral se ensina", em diversos contextos de ensino e aprendizagem.

Para caracterização de gêneros orais, Schneuwly e Dolz (2004) afirmam que é indispensável que se proceda a uma coleta de documentos autênticos; quanto mais o corpus for rico e variado, mais a observação se estenderá a realizações textuais diversas correspondentes aos gêneros trabalhados. Na perspectiva dos autores, por se tratar da escolarização de gêneros, as atividades iniciais da sequência didática constituem-se da observação de gêneros orais de referência. 
Em solo brasileiro, ressaltamos a contribuição de Gomes-Santos (2012), em torno do gênero exposição oral. $\mathrm{O}$ autor propõe a descrição das etapas que caracterizam a elaboração desse gênero: desde seu planejamento (acervo de informações e sua recomposição) até a realização da exposição oral propriamente dita, por meio da apresentação de exemplos de atividades escolares e de exposições realizadas por crianças dos primeiros anos do ensino fundamental. Seu estudo se coloca como "uma caixa de ferramentas a ser recomposta em novas sequências de ensino, com os ajustes que diferentes turmas e situações exigirem" (GOMES-SANTOS, 2012, p.18). Diante das considerações apresentadas ao longo de seu trabalho, o autor acredita que

[...] ao ensinar a exposição oral, a escola estará incrementando os modos de acesso e apropriação do saber por seus alunos, ao mesmo tempo que poderá ampliar os universos de diálogo passíveis de serem construídos por eles com diferentes auditórios, nos primeiros anos do ensino fundamental e também nos outros projetos de vida com que se acharem envolvidos, na escola e fora dela (GOMES-SANTOS, 2012, p.147).

Interessa-nos, de modo bastante particular, a discussão que o autor promove com os dados da constituição multissemiótica da exposição oral, tendo em vista o conjunto das múltiplas semioses empregadas conjuntamente na produção desse gênero: elementos prosódicos, expressividade facial e olhar, gestualidade.

Em recentes publicações, Rojo (2012, 2013), Rojo e Barbosa (2015) têm-se debruçado na discussão destas questões - a multimodalidade, os multiletramentos - e proposto atividades didáticas que solicitam o trabalho com os gêneros multimodais em sala de aula (anime $^{17}$, fotorreportagem, vídeo de animação, para citar apenas alguns exemplos). Nos termos das autoras, o texto multimodal ou multissemiótico é aquele que recorre

A mais de uma modalidade de linguagem ou a mais de um sistema de signos ou símbolos (semioses) em sua composição. Língua oral e escrita (modalidade verbal), linguagem corporal (gestualidade, danças, performances, vestimentas

\footnotetext{
${ }^{17}$ Termo que define os desenhos animados de origem japonesa e também os elementos relacionados a esses desenhos (ROJO, 2012).
} 
- modalidade gestual), áudio (música e outros sons não verbais - modalidade sonora) e imagens estáticas e em movimento (fotos, ilustrações, grafismos, vídeos, animações - modalidades visuais) (ROJO; BARBOSA, 2015, p.108).

Depreendemos, assim, que a interdependência dessas múltiplas semioses na produção e recepção de gêneros discursivos sugere condições de enunciação diversas e, consequentemente, implica novas maneiras de se pensar o ensino e aprendizagem de língua materna. Instaura-se, pois, um desafio do ponto de vista dos saberes escolares e das metodologias.

Para finalizar a apresentação dos Módulos Didáticos que caracterizam o procedimento metodológico assumido em nossa pesquisa-ação, passamos a descrever, a seguir, o Módulo 5 - Circulação. Conforme assinalam os estudos de Lopes-Rossi (2006, 2011), a produção textual do aluno merece ser lida, assistida, ouvida, comentada, divulgada ao público e, de alguma forma, merece circular na escola ou fora dela; esse é o objetivo final de um projeto pedagógico e a melhor motivação que se pode oferecer aos alunos.

\subsubsection{Módulo 5 - Circulação}

Entendemos que várias são as possibilidades de circulação de um gênero discursivo: produção de um jornal para comunidade ou de um blog de notícias, elaboração de cartazes com temas sociais (prevenção da gripe, combate à dengue, adoção de cães etc.), apresentação de um espetáculo teatral, elaboração de propagandas para uma feira (venda de objetos usados ou objetos decorativos, feitos com material reciclado), concurso de paródias, execução de um programa de rádio, confecção de um livro com relatos de uma excursão escolar, produção de um livro de receitas para um público específico (diabéticos, pessoas com intolerância à lactose, chocólatras etc.), e assim por diante.

O módulo didático voltado para circulação do gênero preenche, de certa forma, uma lacuna apontada pelo Programa Nacional do Livro Didático - PNLD (BRASIL, 2010), para quem as produções textuais são, via de regra, encaminhadas ao professor - interlocutor preferido, às vezes único - a fim de que o aluno obtenha simplesmente nota. $\mathrm{O}$ aluno escreve 
o texto já sabendo que será avaliado e que sua produção ficará restrita ao ambiente escolar, tendo quase sempre como leitores o professor ou, no máximo, os colegas de classe.

Mencionamos, nessa direção, o posicionamento dos PCN de Língua Portuguesa (BRASIL, 1998), os quais orientam que a razão de ser das propostas de leitura e escuta é a compreensão ativa, e não a decodificação e o silêncio; ressalta ainda que a razão de ser das propostas de uso da fala e da escrita é a interlocução efetiva, e não a produção de textos para serem objetos de correção do professor.

A proposição de um módulo didático dedicado à circulação do gênero produzido pelo aluno encontra respaldo na teoria bakhtiniana da linguagem, quando o filósofo russo se refere à conclusibilidade do enunciado. Nos termos do autor, desde o início, o interlocutor aguarda a resposta de outros, espera uma ativa compreensão responsiva; "é como se todo o enunciado se construísse ao encontro dessa resposta" (BAKHTIN, 2003[1979], p.301). Entendemos, assim, que a possibilidade de divulgação do gênero discursivo a ser produzido em sala de aula pode impulsionar os alunos para a experimentação de práticas de linguagem mais próximas da vida.

Neste capítulo, buscamos apresentar o posicionamento teórico-metodológico assumido neste trabalho ao trazermos para discussão a categoria gênero discursivo e os procedimentos didáticos de sua apropriação pelo discurso do ensino. Os cinco (05) módulos anteriormente descritos configuram a proposta de sequência didática em torno do gênero discursivo texto dramático que caracteriza nossa pesquisa-ação (apresentada no capítulo V).

O próximo capítulo visa problematizar nosso objeto de investigação (texto dramático) como objeto de ensino de língua materna, de modo a promover um diálogo entre o construto teórico dos estudos teatrais que sustentam essa prática de referência e a conjuntura teórica dos estudos da linguagem que nos permite falar desse gênero discursivo na escola, na aula de língua portuguesa, especialmente. 


\section{CAPÍTULO II}

\section{O gênero discursivo texto dramático: um desafio multimodal}

O mistério teatral é justamente esta identificação profunda de cores, ritmos, música, movimento e palavra com a alma do espectador.

Maria Clara Machado

A questão que se coloca neste capítulo se volta para a problemática da escolarização do texto dramático: de que modo podem-se correlacionar texto dramático (na acepção de gênero multimodal e como arte), teorias linguísticas e ensino de língua portuguesa? Para subsidiar essa discussão, recorremos, primeiramente, aos aportes teóricos dos estudos teatrais para conceituação e caracterização de nosso objeto de pesquisa. Na sequência, apresentamos as teorias linguísticas que nos autorizam pensar texto dramático como objeto de ensino de língua materna.

$\mathrm{Na}$ primeira seção, enfatizamos nosso posicionamento a respeito da terminologia "texto dramático" atribuída ao gênero que se constitui objeto de investigação deste trabalho. 


\subsection{Da nomeação do objeto de investigação: texto dramático}

A atribuição do nome texto dramático ao gênero selecionado para este estudo merece especial atenção, pois revela, obrigatoriamente, um posicionamento teórico-metodológico para caracterização deste gênero e implica, de igual forma, renúncia a outras designações.

O número de rótulos conferidos a gêneros pertencentes à esfera teatral é relativamente vasto; são muitas nomenclaturas que apontam para a complexidade que envolve os planos de produção destas práticas discursivas. Apenas para citar alguns exemplos: texto de teatro (teatral) ou texto dramático, roteiro, peça de teatro (teatral) - que remetem à produção escrita; drama, representação (cênica), apresentação/espetáculo (teatral), encenação e dramatização que remetem à produção oral. Diante de tantas formas de dizer esse gênero, entendemos ser fundamental expor o critério que orienta nossa opção por "texto dramático". Nessa direção, Gomes-Santos (2004, p.85) salienta que "os modos de tratamento - o que inclui, entre outros procedimentos, a nomeação e a caracterização - do objeto-gênero relacionam-se, entre outras motivações, com a própria construção dos dados como objeto de pesquisa".

A seleção por essa nomenclatura pauta-se na tríade que sustenta a esfera do teatro, qual seja: ator, texto e público (MAGALDI, 1997). Concebido como um dos pilares que edifica o fazer teatral, o texto dramático se solidifica como gênero materializado na palavra escrita, projetado para ser, também, dito a uma plateia. Do mesmo modo, Chacra (2010, p.55) assegura que não se pode falar em teatro "se não houver alguém em cena que faça alguma coisa e alguém que assista. Entre um e outro, algo os deve unir. Esse algo é aquilo que se pode chamar "texto teatral"'.

O texto dramático, tal como o concebemos, projeta um dizer-fazer e a representação cênica opera com esse dizer-fazer. Admitimos, assim, a existência de uma dupla acepção para esse gênero discursivo:

1) peça escrita para o teatro, composição de responsabilidade do dramaturgo, a ser executada por atores e 2) conjunto de sinais, signos e símbolos - verbais e não verbais proferidos durante a realização de um espetáculo, em outros termos, aquilo que os atores dizem e fazem - palavras e ações (UBERSFELD, 2010). 
O tratamento que dispensamos ao nosso objeto de investigação leva em conta a coexistência das duas acepções anteriormente mencionadas. Pressupomos, de saída, que o texto dramático convoca a experimentação de múltiplas semioses: oralidade e escrita, ações e gestos, movimento do corpo e dos olhos, por exemplo. Diante disso, faz-se necessário eleger um caminho epistemológico que sustente nosso objeto de pesquisa no campo dos estudos da linguagem e, em diálogo com os estudos teatrais, possa fazer-nos compreender a relação de interdependência constitutiva desse gênero, conforme assegura Mello (2004), para quem a arte teatral configura-se:

[...] múltipla, complexa e paradoxal, formada por duas substâncias contraditórias, porém intrínsecas, a literária e a cênica: ao mesmo tempo produção literária - texto dramático, e representação cênica concreta. Arte que se repete sem jamais ser a mesma. Real e imaginária. [...] Arte de um só o autor, e de muitos - cenógrafos, atores, diretores; leitores, espectadores (MELLO, 2004, grifo nosso).

Consideramos, nesse sentido, que os estudos teatrais têm muito a contribuir. Não há direcionamento único para a discussão que se segue, tendo em vista que os estudiosos do teatro abordam a relação entre texto dramático escrito e texto dramático oralizado/representado, considerando-os ora como práticas excludentes, ora como práticas complementares, assunto de que tratamos na próxima seção.

\subsection{Texto dramático escrito versus texto dramático oralizado/representado}

Ao longo da história do teatro, é reincidente a tensão entre aqueles que definem o espetáculo como condicionado ao texto e os que advogam um trabalho de encenação independente e absoluto; trata-se, segundo Ryngaert (1995, p.30), da "velha luta de poder entre duas metades inseparáveis, o texto e o palco, que se procura dissociar sempre que uns passam a temer os 'literatos' e os outros os 'histriões'”.

Conforme constatam os trabalhos de Mello (2004) e Pavis (2011), nos estudos teatrais, há aqueles que buscam propor uma visão separatista do texto dramático escrito e do texto 
dramático oralizado/representado: se a preferência é dada ao texto, a tendência é denominada textocentrismo, se é dada à representação, é denominada cenocentrismo.

Por um lado, os que defendem o textocentrismo são marcados pela sacralização do texto, em detrimento da representação. De acordo com Pavis (2011, p.191), nesta tendência, “o texto não é descrito em sua enunciação cênica, ou seja, como prática da cena, mas como referência absoluta e imutável, como pivô de toda encenação”. Nessa direção, Ubersfeld (2010, p.4) assinala que "o principal perigo dessa atitude reside certamente na tentação de congelar o texto, de sacralizá-lo a ponto de bloquear todo o sistema da representação e a imaginação dos intérpretes (encenadores e atores)".

No outro extremo, estão os cenocentristas, que consideram o texto escrito como um script incompleto à espera de um palco. Nesse sentido, o espetáculo prevalece sobre o texto e a teatralidade é buscada fora da escritura teatral. O teatro moderno, adepto desta tendência, considera o espetáculo com total desprendimento do texto, e colocam este como algo desnecessário para as artes cênicas. Conforme assinala Ubersfeld (2010, p.4), o cenocentrismo consiste da recusa, por vezes radical, do texto, destacando que "o teatro reside inteiramente na cerimônia que se realiza diante ou no meio dos espectadores. O texto é apenas um dos elementos da representação, talvez o menor".

Depreende-se que as duas correntes apresentadas polarizam "texto dramático" e "representação cênica". De um lado, a possibilidade da leitura do texto dramático como procedimento que se basta em sim mesmo, “[...] sempre se pode ler um texto de teatro como não-teatro, que não há nada num texto de teatro que impeça de lê-lo como um romance, de ver, nos diálogos, diálogos de romance, nas didascálias, descrições [...] (UBERSFELD, 2010, p.5)". De outro, a ocorrência de encenações teatrais que não partem de um roteiro determinado a priori - é o caso das improvisações dramáticas ${ }^{18}$, técnica teatral que consiste da criação espontânea, a partir de um fato, uma situação ou uma ação proposta (REVERBEL, 2007).

O tratamento isolado ora do texto dramático, ora da representação cênica permite-nos afirmar, ainda, que tais práticas subsistam por si só, já que podemos assistir a uma peça sem nunca termos lido o texto que lhe deu origem, da mesma forma que podemos ler um texto,

\footnotetext{
18 No universo teatral, Chacra (2010) cita como exemplo a commedia dell'arte, cujo teatro se realizava all'improviso. Nessa direção, Roubine (1998) destaca o Théatre du Soleil, que desenvolve um amplo trabalho de improvisação, calcado em indicações de referência.
} 
sem ter assistido à referida peça em um teatro (DIEGUES, 2010). Além disso, segundo Roubine (1998, p.78), é possível admitir a coexistência de dois textos bastante diferentes, "aqueles que podem ser apreciados, conforme a tradição nos havia acostumado, no simples ato de leitura independentemente de sua existência cênica [...] e os textos que não existem nem pretendem existir fora do teatro".

Para esta pesquisa, não buscamos situar em dois pólos o teatro com texto e o teatro sem texto; promovemos, pelo contrário, o encontro entre texto dramático escrito e texto dramático oralizado/representado e, assim, como propõe Ubersfeld (2010), libertamo-nos do conflito entre aqueles que apenas privilegiam o texto, enquanto obra literária, e aqueles que, envolvidos com a arte dramática, desprezam a instância escritural.

Tomamos por embasamento a sugestão de Grésillon (1995, p.269) de que se busque o equilíbrio, conforme destaca:

Para além do que puderem ser ao longo da história, para além do que sejam hoje as relações entre (escritura do) texto e encenação, para além das rivalidades e exclusões recíprocas que possam existir nesse campo entre escritores $[\ldots]$ e gente de teatro, $[. .$.$] para além dessas lutas intestinas entre$ texto e representação, o que importa, do meu ponto de vista, é que tais relações são altamente dialéticas. Há, necessária e simultaneamente, alteridade e interdependência. (grifos nossos)

Dessa maneira, o gênero discursivo texto dramático, tal como o concebemos nesta pesquisa, estabelece com a representação cênica uma relação de reciprocidade muito estreita, em outras palavras, o texto dramático busca a encenação, assim como a encenação se ancora no texto escrito. Disso decorre o estatuto que lhe é conferido por muitos e do qual compartilhamos: "um texto teatral não é para ser lido, mas encenado em um palco, caso contrário, ele exercerá somente sua função literária" (CALZAVARA, 2009, p.150). A seguir, passamos a aprofundar essa discussão. 


\subsection{Relações de interdependência entre texto dramático escrito e texto dramático oralizado/representado}

Rosenfeld (1993, p.75-76) assevera que o texto dramático, enquanto obra literária, apresenta diálogos livrescos e por maiores que sejam suas virtudes teatrais inerentes, tais como ritmo, movimento, dramaticidade, diálogo, é na encenação que lhes dá sua verdadeira vida, pois é no palco que adquirem riqueza plena, devido à cooperação de técnicos, atores, cenógrafos, entre outros. Nas palavras do autor (1993, p.75-76), "sua verdadeira força não se revela ao leitor, mas somente ao espectador".

Entendemos, assim, que o texto dramático, quando apenas lido, assume uma feição diferente da que possui quando representado. No primeiro caso, o texto não foi ativado por uma voz humana além do seu autor que não está presente para pronunciá-lo; no segundo caso, o texto é dito pelo ator e já está servido por uma cena, por signos prosódicos, visuais, gestuais dos quais já não se pode mais fazer abstração (PAVIS, 2011).

Essa posição é assegura também por Magaldi (1997), para quem a leitura de um texto dramático traz um enriquecimento artístico e cultural, mas não chega a constituir o fenômeno do teatro. Para o autor, a existência de uma peça marca o início da preparação do espetáculo, já o texto, "alinhado na biblioteca, sem alguém que o encene, também não é teatro. Será sempre mais fecundo pensar a arte dramática na totalidade dos seus elementos" (MAGALDI, 1997, p.15-16).

Dessa afirmação depreendemos que um espetáculo tem como ponto de partida um texto escrito, com diálogos, indicações cênicas, personagens e conflito, "como obra literária [...] está completa: como texto teatral, entretanto, exige, para realizar-se integralmente, ser encenado", conforme assinala Peixoto (1986, p.24). Em uma palavra: o texto dramático configura-se como gênero fonte e destino da representação cênica, gênero que, embora situado na literatura, exige ou compreende a teatralidade (LISBÔA, 1998).

As reflexões apresentadas até o momento levam-nos a buscar, nos aportes teóricos dos estudos teatrais, as possibilidades de interlocução de nosso objeto de estudo, em outras palavras, discutir os vários desdobramentos enunciativos que envolvem os processos de 
produção escrita e oral desse gênero discursivo: escrever para leitores, atores, para um público de teatro, atuar como personagem, dialogar com outro personagem etc.

\subsubsection{Possibilidades de interlocução do texto dramático (escrito e oralizado/representado)}

Ao tratarmos do texto dramático oralizado/representado ou simplesmente “representação cênica", retomamos Ubersfeld (2010) que assevera a existência de um discurso enunciador (I), que tem como locutor o dramaturgo (IA), ao qual se juntam, na representação, outros locutores (IA') - atores e encenador ${ }^{19}-\mathrm{e}$, como interlocutores, o público (IB). A autora constata, ainda, a presença de um discurso enunciado (II), que tem como locutor a personagem (IIA) e, como interlocutor, outra personagem (IIB). Consideramos, assim, que a produção oral do texto dramático prevê a colaboração de um dramaturgo (quem escreve o texto), de atores (quem efetivamente interpreta o papel no palco) e de encenadores/diretores (responsáveis por organizar/dinamizar a apresentação como um todo); de modo amplo, essa coletividade tem por interlocutor o público de teatro.

Do ponto de vista do ator, há mais um desdobramento enunciativo caracterizado pela interlocução entre personagens. Em outras palavras, na representação cênica, o ator dirige sua fala a um parceiro de cena; a natureza dramática nasce, justamente, da inter-relação entre um "eu" e um "outro", e é por meio desse encontro que o ator se constitui em cena como personagem (SPOLIN, 2010). Na tarefa de representar um texto dramático, o ator, então, vivencia algumas dualidades, “ao mesmo tempo em que é ele próprio, é também 'o outro' (a personagem); ao mesmo tempo em que se comunica com seus colegas-personagens, também se comunica com o público" (CHACRA, 2010, p.73).

Nesse sentido, observamos que na representação cênica há uma ocorrência teatral em duas direções: de um lado, estabelece-se o jogo entre atores e, de outro, o encontro entre atores e espectadores para a concretização do fenômeno artístico. A relação construída entre

\footnotetext{
${ }^{19}$ Roubine (1998) também compreende que, no momento da representação cênica, o dramaturgo e a coletividade a que ele se insere (atores, encenador/diretor) participam da elaboração do texto.
} 
atores é, então - e necessariamente - estendida a um público, que se manifesta, também, como o "outro", conforme assinala Ryngaert (1995, p.109),

$\mathrm{Na}$ comunicação mais imediata, um ator fala a um ator, assim como na vida ordinária um emissor conversa com um receptor. Mas esses atores [...] são apenas a expressão de uma outra troca situada desta vez ao nível da ficção, em que uma personagem conversa com outra personagem. Por trás das personagens encontra-se o verdadeiro emissor de todas essas falas, o autor, que se dirige a um público. $\mathrm{O}$ público tem portanto o estatuto de destinatário indireto, pois é a ele, em última instância, que todos os discursos são dirigidos, ainda que raramente os sejam de maneira explícita.

Kerbrat-Orecchioni (1984, p.48), linguista estudiosa da interação, também constata a existência de uma cadeia de interlocutores, pela qual o diálogo teatral é estabelecido. A autora elege o público como destinatário indireto, mesmo sem ele ser "verdadeiramente integrado na relação de expressão, no entanto, funciona como uma testemunha cuja presença é conhecida e aceita pela troca verbal ${ }^{20,}$.

Em relação ao fenômeno artístico que caracteriza a apresentação teatral, Peixoto (1986) assinala que entre ator e plateia existe a consciência de uma cumplicidade fundamental para existência da representação cênica: ambos se reconhecem como participantes de uma farsa ensaiada, que procura imitar a realidade. Segundo Chacra (2010), tal cumplicidade é gerada pela ilusão do teatro - realidade de palco ou o "como se" e suas convenções. Somente juntos - ator e espectador - podem constituir aquilo que se chama teatro. Com enfeito,

\begin{abstract}
A imagem de que existe um cordão umbilical que une o ator ao espectador nos parece adequada, pois aquele vive e respira através deste, durante o ato da representação. Todos os esforços despendidos pelo artista - ensaios, técnicas, memorização de textos etc. - têm como meta a conquista de um momento, que começa com a chegada do público e termina quando ele se vai. Cabe ao espectador recriar no seu interior aquilo a que assiste. Agora, há a inversão do cordão. É o ator, através do seu desempenho, quem alimenta a presença e a imaginação da assistência. Nota-se, então, que um necessita do outro para existir. Se uma das partes não comparece ao teatro, não há espetáculo (CHACRA, 2010, p.84).
\end{abstract}

\footnotetext{
${ }^{20}$ Tradução nossa de: "être véritablement intégré à la relation d'allocution, il fonctionne cependant comme un témoin, dont la présence est connue et accepteé par de 1 'échange verbal".
} 
As possibilidades de interlocução do texto dramático oralizado/representado se fazem presentes, também, na produção escrita do gênero. É possível depreender três instâncias de interlocução que sustentam os processos de produção escrita do texto dramático - ampliando, desse modo, a proposta de Ubersfeld (2010). É o que nos propomos apresentar nas linhas que seguem.

Para explicitar a primeira instância de interlocução aqui estabelecida, entendemos ser necessário considerar, de antemão, o fato de que o texto dramático encontra-se, inevitavelmente, arraigado à historicidade literária. Desta maneira, quando alguém se propõe a escrever um texto dramático, é sabido a exigência de atender a um "leitor-literário" que terá acesso à história apenas por meio da materialidade do texto. Para Mello (2004, p.94), "trata-se de uma enunciação entre um EU-comunicante e um TU-interpretante, entre um sujeito autor e o leitor - ambos sujeitos empíricos -, e a obra como veículo de interação entre eles”.

Por outro lado, quando assumimos o texto dramático no bojo da esfera teatral, é consentido afirmar que aquele responsável pela escrita (o dramaturgo) destina seu texto a um "leitor-ator", que buscará as marcações específicas para a interpretação da ação descrita. As didascálias (recomendações explícitas do dramaturgo sobre como os intérpretes devem atuar), por exemplo, ratificam essa segunda possibilidade de interlocução.

No processo de escrita de um texto dramático, deve-se considerar, obrigatoriamente, uma projeção maior, um direcionamento de todo o texto para uma plateia provável, já que a relação com o espectador é visada no momento da escrita, conforme propõe Ryngaert (1995). Tal direcionamento pode ser recuperado explicitamente no texto escrito por meio dos apartes - fragmentos em que o autor escreve algo para uma personagem segredar apenas à plateia, em tom de confidência. De acordo com Pavis (2008, p.21), o aparte assinala a "verdadeira" intenção ou opinião do caráter da personagem, de modo que o espectador saiba a que se ater em relação àquela situação; este discurso pode, inclusive, ser acompanhado por "um jogo cênico capaz de torná-lo verossímil (afastamento do ator, mudança de entonação, olhar fixo na sala)".

O fenômeno do teatro, como vimos, edifica-se na correlação entre texto dramático escrito e texto dramático oralizado/representado e se destina a uma plateia desde o momento da sua concepção escrita até a encenação. Essa posição é referendada por Spolin (2010, 
p.241), para quem a plateia deveria ser o membro mais reverenciado; segundo a autora, "sem plateia, não há teatro".

Nesse sentido, por ser vocacionado para a cena, o texto dramático carrega, inevitavelmente, marcas de sua teatralidade (PASCOLATI, 2009). Na próxima seção, apresentamos os aspectos constitutivos do texto dramático escrito que revelam sua interdependência com a representação cênica e apontam, sobretudo, para a construção heterogênea desse gênero discursivo.

\subsubsection{O texto dramático escrito e sua projeção para o palco}

No texto dramático escrito, há matrizes textuais de representatividade, conforme assinalam Toro (1989) e Ubersfeld (2010). O postulado de que o processo de escrita do texto dramático já determina um funcionamento no palco é compartilhado por outros estudiosos do teatro, dentre eles Grésillon (1995, p.282), para quem "o componente cênico coexiste com o texto desde o projeto inicial, embora de modo latente, não dito, até mesmo não dizível, como que recalcado pelo código da linguagem escrita".

Do mesmo modo, Lisbôa (1998, p.32) assevera que há uma teatralidade virtual no texto dramático escrito, que faz com que ele seja identificado "não como conto, romance, crônica, ou qualquer outra obra literária, justamente por trazer em si a possibilidade para cena".

A ocorrência do texto dramático escrito e sua projeção para o palco é descrita de modo detalhado no trabalho de Diegues (2010). A autora apresenta algumas especificidades que tornam o texto dramático distinto de outros gêneros discursivos, como por exemplo, a possibilidade da inexistência da figura do narrador, já que no texto escrito para o teatro as falas das personagens são apresentadas de modo direto, por meio de diálogos, monólogos e apartes.

A habitual ausência do narrador é apenas uma das características do texto dramático escrito, sendo possível, a partir dela, apreender outras duas bastante distintas, porém, indissociáveis: a sequência de diálogos entre as personagens arroladas na história e as 
didascálias, também conhecidas como indicações cênicas ou rubricas, sequências textuais geralmente descritivas - que entremeiam todo o texto (PAVIS, 2008).

Assim, temos que o texto dramático escrito constrói-se de modo heterogêneo, a partir de sequências textuais que têm por função contar a história (diálogos) e, de algum modo, situá-la (rubricas) aos leitores (literários, atores, diretores); essa construção, reiteramos, é orientada para o palco. A esse respeito, Ubersfeld (2010) distingue essas sequências textuais pelo fato de terem como sujeito da enunciação as figuras do "dramaturgo" e das "personagens"; o primeiro, responsável pela totalidade das didascálias, e o segundo, pelo conjunto dos diálogos.

Nessa direção, Toro (1989) caracteriza o texto dramático escrito como duplo: uma parte composta por diálogos entre as personagens, mais destinados a serem falados, do que lidos e outra parte que são as direções de palco, as didascálias, mais destinadas a serem lidas do que faladas.

A produção escrita de nosso objeto de estudo admite, assim, a alternância entre duas sequências tipológicas predominantes: a conversacional - diálogos entre as personagens - e a descritiva - conjunto das didascálias. Com efeito,

\footnotetext{
A distinção linguística fundamental entre o diálogo e as didascálias tem a ver com a enunciação, isto é, com a pergunta quem fala? No diálogo, é este ser de papel que chamamos de personagem (distinta do autor); nas didascálias, é o próprio autor que: a. nomeia as personagens (indicando a cada momento quem fala) e atribui a cada uma um lugar para falar e uma parte do discurso; b. indica os gestos e as ações das personagens (UBERSFELD, 2010, p.7, grifos da autora).
}

Responsável pelas didáscalias, o autor do texto dramático oportuniza aos atores construir a ação descrita, a partir das indicações disponíveis. Conforme assinala Ryngaert (1995), essas sequências textuais constituem o principal material da representação; não se destinam a ser pronunciadas no palco, mas ajudam o leitor a compreender e a imaginar a ação e as personagens e são igualmente úteis ao diretor e aos atores durante os ensaios. 
As rubricas podem ser classificadas de acordo com a informação que apresentam e determinadas, sobretudo, pelo tipo de interlocutor a que se destinam. Helbo (1989, p.52) distingue quatro tipos:

- Pensadas para o ator: geralmente contém detalhes referentes à atuação.

- Pensadas para a ação: essas anotações referem-se ao cenário, vestuário, iluminação, efeitos sonoros, música.

- Pensadas para o leitor, as quais não têm nada a ver com a concretização da cena. $[\ldots]$

- Pensadas para o espectador implícito ${ }^{21}$.

Depreendemos, assim, que as indicações cênicas referem-se ora à interioridade da personagem (movimentação, ação, gesto, expressão facial, entonação de voz), ora à ambientação da cena (cenário, luz, som etc.) e são fundamentais para a construção do espetáculo. Essas marcações nos ajudam a compreender a relação de interdependência constitutiva de nosso gênero discursivo: texto que se projeta para o palco; representação cênica que se apóia no modo escritural.

A possibilidade para a cena leva-nos a pensar o texto dramático como gênero discursivo multimodal. Em vista disso, entendemos que os estudos linguísticos sobre letramento(s), bem como a emergência dos estudos dos multiletramentos mereçam ser revisitados, pois configuram as bases teóricas do que hoje entendemos como multimodalidade que tão importantes contribuições podem nos trazer, conforme passamos a discutir.

\subsection{Para pensar o texto dramático nos estudos linguísticos: Letramento(s), Multiletramentos e Multimodalidade}

Soares (2009) salienta que uma das primeiras ocorrências da palavra "letramento", entre especialistas da Educação e da Linguística, no Brasil, está presente na obra de Kato

\footnotetext{
${ }^{21}$ Tradução nossa de: "Pensadas para el actor: usualmente conciernen detalles de actuación. Pensadas para la puesta: esas anotaciones se referien al decorado, vestuario, iluminación, efectos sonoros, música. Pensadas para el lector, las cuales no tienen nada que ver con la concretización en escena. [...] Pensadas para el espectador implícito".
} 
(1986), intitulada No mundo da escrita: uma perspectiva psicolinguística, em que a autora faz uma discussão entre o processo psicomotor e individual de aquisição do sistema de escrita (alfabetização), e o processo psicossocial consequente da aquisição e do contato com a cultura escrita (letramento). Dois anos mais tarde, Tfouni (1988), na obra Adultos não alfabetizados: $o$ avesso do avesso, descreve os processos distintos, porém complementares e interdependentes, da alfabetização e do letramento. Na década de 90, o termo reaparece no título do livro organizado por Kleiman (1995), Os significados do letramento, no qual a autora propõe o letramento como um conjunto de práticas sociais que usam a escrita, como sistema simbólico e como tecnologia, em contextos específicos, para objetivos também específicos.

No âmbito nacional, o conjunto dessas obras marca, para os estudos da linguagem, um redirecionamento e ampliação ao que na época se propunha como alfabetização. A esse respeito, Rojo (2009, p.98) esclarece que

[...] o termo alfabetismo tem um foco individual, bastante ditado pelas capacidades e competências (cognitivas e linguísticas) escolares e valorizadas de leitura e escrita (letramentos escolares e acadêmicos), numa perspectiva psicológica, enquanto o termo letramento busca recobrir os usos e práticas sociais de linguagem que envolvem a escrita de uma ou de outra maneira, sejam eles valorizados ou não valorizados, locais ou globais, recobrindo contextos sociais diversos (família, igreja, trabalho, mídias, escola etc.), numa perspectiva sociológica, antropológica e sociocultural (grifos da autora).

O termo letramento advém da palavra em inglês literacy que, no contexto internacional, já recobria ao mesmo tempo os significados de alfabetização e letramento (SOARES, 2009). O termo foi ressignificado no final dos anos 70 e início dos anos 80, a partir de estudos etnográficos que passaram a focalizar o lado social do letramento, em detrimento de seu lado cognitivo. A obra de Street (1984), Literacy in Theory and Practice (Letramento na Teoria e na Prática), inaugura os New Literacy Studies (Novos Estudos do Letramento, NEL), que buscam apontar, desde então, para a heterogeneidade das práticas sociais de leitura, escrita e de uso da língua/linguagem.

Divulgada, em nosso país, sobretudo, por Kleiman (1995), a obra de Street (1984) propõe a noção de letramento ideológico em oposição à noção de letramento autônomo. $\mathrm{O}$ conceito de letramento autônomo circunscreve-se em uma perspectiva grafocêntrica, ou seja, 
focalizada na estrutura verbal (na aquisição de habilidades que envolvem o sistema da escrita), atendendo ao que, no Brasil, denominava-se alfabetização. Já o conceito de letramento ideológico engloba a prática social situada, que abrange, além da instituição escolar, outras agências de letramentos. Nesta nova abordagem dos estudos do letramento, ganha relevo o papel do contexto e, nesse movimento teórico, o conceito passa a ser pluralizado. Nessa direção, Soares (2002, p.155-156) observa que

[...] essa necessidade de pluralização da palavra letramento e, portanto, do fenômeno que ela designa já vem sendo reconhecida internacionalmente, para designar diferentes efeitos cognitivos, culturais e sociais em função ora dos contextos de interação com a palavra escrita, ora em função de variadas e múltiplas formas de interação com o mundo - não só a palavra escrita, mas também a comunicação visual, auditiva, espacial.

Em recente trabalho a respeito da produção dos diferentes letramentos, Geraldi (2014) assevera que somos diferentemente letrados segundo os diferentes campos de atividade letrados e iletrados ao mesmo tempo. Assim, para o autor,

\begin{abstract}
Somos ao mesmo tempo competentes e incompetentes leitores e produtores de textos, dependendo de nossos campos de atividade e de nossa circulação pelos diferentes campos de atividade [...] o adjetivo 'diferente', associado ao letramento, nada mais faz do que reconhecer a real complexidade dos usos sociais da linguagem (GERALDI, 2014, p.28-29).
\end{abstract}

Os estudos dos letramentos tendem a acompanhar as mudanças sociais, as quais, consequentemente, refletem nos modos de pensar as pedagogias. Em 1994, nos Estados Unidos, renomados teóricos, pesquisadores dos letramentos, oriundos de três países - Estados Unidos, Inglaterra e Austrália - reuniram-se para discutir as práticas de ensino na contemporaneidade. O grupo formado por dez estudiosos autodenominou-se New London Group (Grupo de Nova Londres, GNL ${ }^{22}$ ). Deste primeiro colóquio resultou um artigo seminal, publicado na Harvard Educational Review, intitulado Pedagogy of Multiliteracies: Designing Social Futures (Uma Pedagogia dos Multiletramentos: Desenhando Futuros

\footnotetext{
${ }^{22}$ A estes estudiosos atribui-se a emergência da teoria dos multiletramentos: Courtney Cazden, Bill Cope, Norman Fairclough, Jim Gee, Mary Kalantzis, Gunther Kress, Allan Luke, Carmen Luke, Sarah Michaels e Martin Nakata.
} 
Sociais). Em 2000, a coletânea denominada Multiliteracies: Literacy Learning and the Design of Social Futures (Multiletramentos: Pedagogia do Multiletramento e o Desenho de Futuros Sociais) reuniu artigos dos pesquisadores do GNL, edificando-se, assim, como obra de referência para os estudos desta ordem ${ }^{23}$.

A ideia preconizada pelo GNL centra-se no fato de que a vida pública, pessoal e profissional das pessoas vem-se modificando consideravelmente, o que traz, como consequência, a transformação radical na cultura e na maneira da comunicação da sociedade contemporânea: por um lado, a constatação da diversidade linguística e cultural e, por outro, a evidente ampliação dos canais e meios (modos semióticos) de comunicação (resultado, principalmente das novas tecnologias). A esse respeito, Rojo (2014, p.250) acrescenta que a

[...] presença ubíqua das tecnologias digitais de informação e comunicação TDICs - coloca-nos diante do mundo e das diversas culturas e acontecimentos em apenas um clique e um toque e em tempo real. Tudo isso tem revolucionado não só o acesso a informações, como também alterado nossa forma de pensar, ver o mundo, ler, escrever e nos relacionar.

Estes dois argumentos, considerados pelo GNL - multiculturas, multimeios (multimodos) -, impulsionaram a seleção do prefixo -multi: se os modos de compreensão e interação da sociedade contemporânea são multissemióticos, os letramentos também devem ser múltiplos. Em uma palavra, tais argumentos justificam o porquê de se pensar em multiletramentos. Conforme observa Kleiman (2014, p.81), os pesquisadores do GNL

[...] advogam por uma concepção de letramento muito mais ampla do que aquela que em geral embasa o trabalho escolar, e propõem o ensino dos multiletramentos, isto é, da inclusão no currículo de todas as formas de representar significados dos diferentes sistemas semióticos - linguístico, visual, sonoro ou auditivo, espacial e gestual - inter-relacionados no texto multimodal contemporâneo.

\footnotetext{
${ }^{23}$ Destacamos, nessa direção, o investimento teórico da pesquisadora brasileira Rojo, em obras de sua autoria ou co-autoria que dialogam com a teoria do GNL e que abordam os multiletramentos: Hipermodernidade, multiletramentos e gêneros discursivos (ROJO; BARBOSA, 2015), Gêneros de texto/discurso e os desafios da contemporaneidade (NASCIMENTO; ROJO, 2014), Escol@ Conectada: os multiletramentos e as TICs (ROJO, 2013), Multiletramentos na escola (ROJO; MOURA, 2012), Letramentos múltiplos, escola e inclusão social (ROJO, 2009).
} 
Esta concepção considera ações pedagógicas específicas que promovem a valorização de todas as formas de linguagem (verbal e não verbal), e levam o indivíduo a ser protagonista no processo dinâmico de transformação e de produção do conhecimento. O conceito de multiletramentos, cunhado pelo GNL, convoca, então, a elaboração de um currículo responsivo social e culturalmente, a fim de desenvolver uma postura crítica, participativa e reflexiva. Nessa perspectiva, o grupo direciona os estudos para o ensino e propõe o que se tornou conhecido como "Pedagogia dos Multiletramentos", assegurando-lhes, em sua proposta, o como pensar os multiletramentos.

Em síntese, conforme já destacou Rojo (2012, p.12), a Pedagogia dos Multiletramentos, proposta pelo GNL, engloba: 1) Prática situada - imersão dos aprendizes em práticas significativas, 2) Instrução explícita - desenvolvimento de uma metalinguagem para descrever e interpretar diferentes modalidades de significados, 3) Enquadramento crítico - análise crítica dos contextos onde significados são construídos e 4) Prática Transformada transformação desses significados.

A partir do entendimento de que uma nova maneira de pensar o letramento é necessária para inserção do indivíduo em um mundo que a compreensão emerge de modo multicultural e multissemiótico (COPE; KALANTZIS, 2000), o GNL elege o conceito de Design como eixo norteador do $o$ quê se pode estabelecer para a teoria dos multiletramentos. O conceito de Design (Projetos ${ }^{24}$ ) contrapõe-se a concepções tradicionais de ensino pautadas em uma visão estática e monomodal da linguagem; os pesquisadores instituem uma visão mais dinâmica de representação da linguagem, da aprendizagem e do mundo, entendendo que os sentidos são construídos por vários e diferentes modos. Segundo os autores, Design configura-se como qualquer atividade semiótica, incluindo a utilização da língua para produção e recepção de textos.

Uma das ideias-chave que direciona a noção dos multiletramentos é a crescente complexidade e a inter-relação dos diferentes modos de significar. Para Cope e Kalantzis (2000), tais estudos abrangem a variedade semiótica de constituição dos textos, que correspondem a específicas modalidades de representar o sentido: linguística, visual, espacial, gestual e sonora.

\footnotetext{
${ }^{24}$ Conceito assim traduzido por Rojo (2013).
} 
A pertinência dos estudos que preconizam os caminhos multimodais para produção dos sentidos decorre da compreensão de que a palavra escrita deixa de ser a principal forma de produzir sentidos e passa a fazer parte de um conjunto que inclui, além de textos verbais, outras semioses. Essa posição encontra respaldo no trabalho de Kress (2000, p.179), para quem o desafio da teoria da multimodalidade "tem sido deslocar a linguagem escrita da centralidade em que ela tem repousado, ou que tem sido atribuída a ela na comunicação pública $^{25 \%}$. A esse respeito, Soares (2002) oberva que

\begin{abstract}
A tecnologia da impressão enformou a escrita, muito mais do que o tinham feito o rolo e o códice, em algo estável, monumental e controlado: estável, porque o texto se torna então reproduzível em cópias sempre idênticas; monumental porque o texto impresso, muito mais que o manuscrito, sobrevive e persiste como um monumento a seu autor e a seu tempo; controlado porque numerosas instâncias intervêm em sua produção e a regulam (SOARES, 2002, p.153).
\end{abstract}

Os estudos dos "multi", por assim dizer, colocam em xeque a escrita como única modalidade de acesso ao conhecimento, cristalizada - em grande medida - pela tradição escolar. Segundo Vincent, Lahire e Thin (2001, p.29), historicamente, a pedagogização, a escolarização das relações sociais de aprendizagem é indissociável de uma "escrituralizaçãocodificação dos saberes e das práticas. [...] O modo de socialização escolar é, portanto, indissociável da natureza escritural dos saberes a transmitir" (grifo dos autores).

Ao documentar interações em sala de aula, Rojo (2001) observou a presença do texto escrito de três modos distintos: retrospectivo, empírico e prospectivo. Conforme assinala a autora, as práticas de letramento escolar configuram-se historicamente dependentes "de uma ideologia da letra e da escrita, do letrado, do poder do escriba, da regra, da reificação, normatização e padronização da língua e da linguagem (escrita), das relações de poder e lei prescritas, ensinadas, proscritas - pela escola no letramento escolar" (ROJO, 2001, p.259).

Nesse sentido, o movimento teórico dos estudos dos multiletramentos busca promover um redirecionamento da escrita como forma central e o reconhecimento de outros modos

\footnotetext{
${ }^{25}$ Tradução nossa de: "The effect of this revolution has been to dislodge written language from the centrally which it has held, or which has been ascribed to it, in public communication".
} 
(outras semioses) para a produção da linguagem. Conforme assegura Jewitt (2008, p.246), os estudos multimodais tratam

[...] das configurações situadas em relação à imagem, ao gesto, ao olhar, à postura corporal, ao som, à escrita, à música, ao discurso etc. Na perspectiva multimodal, imagem, ação e, assim por diante, são referidos como modos, como conjuntos organizados de recursos semióticos para construção de significados ${ }^{26}$.

A respeito dos estudos que enfatizam a multimodalidade, Kress (2000) orienta que sejam observados em pelo menos três caminhos distintos, mas que mantêm relações entre si. Assim, temos:

Primeiramente, todos os textos são multimodais. A meu ver, nenhum texto pode existir em um único modo, de modo que todos os textos são sempre multimodais, embora, uma modalidade entre essas seja dominante. Em segundo lugar, há textos e objetos (do tipo semiótico) que existem predominantemente em um modo ou mais, além do modo (multi-) da linguagem. E em terceiro lugar, existem sistemas de comunicação e de representação que são reconhecidos na cultura por serem multimodais, embora, na verdade, todos esses sistemas são ${ }^{27}$ (KRESS, 2000, p.184).

Nessa direção, Dionísio (2011) considera o fato de, se as ações sociais são fenômenos multimodais, consequentemente, os gêneros discursivos também o são, já que, quando falamos ou escrevemos um texto, empregamos no mínimo dois modos de representação da linguagem: palavras e gestos, palavras e entonações, palavras e imagens, palavras e tipografias, palavras e sorrisos, palavras e animações etc.

Rojo e Barbosa (2015) resumem a questão ao afirmarem que, na contemporaneidade em que escrita e fala se misturam em imagens estáticas, em movimento e com sons, a palavra

\footnotetext{
${ }^{26}$ Tradução nossa de: "Multimodality attends to meaning as it is made through the situated configurations across image, gesture, gaze, body posture, sound, writing, music, speech, and so on. From a multimodal perspective, image, action, and so forth are referred to as modes, as organized sets of semiotic resources for meaning making".

${ }^{27}$ Tradução nossa de: "First, all texts are multimodal. It is my contention that no text can exist in a single mode, so that all texts are always multimodal although one modality among these can dominate. Second, there are texts and objects (of a semiotic kind) which exist predominantly in a mode or modes other than the (multi-) mode of language. And third, there are systems of communication and representation which are acknowledged in the culture to be multimodal, though, in fact, all such systems are multimodal".
} 
'texto' se estende a enunciados de "novo" tipo, de tal modo que parece ser possível falar em "textos orais" e "textos multimodais".

O exposto permite-nos salientar que, para compreensão das multissemioses presentes no texto dramático, conforme dupla acepção defendida no início deste capítulo - texto escrito para ser representado e texto oralizado, efetivamente interpretado em um palco - será preciso observá-lo sob a ótica da multimodalidade ${ }^{28}$.

\subsection{Para pensar o texto dramático no ensino de língua portuguesa: do escritural para o multimodal}

Quanto mais complexa a sociedade, mais gêneros entram em circulação; se os usos sociais da linguagem são vários, a natureza dos gêneros também será múltipla. Nesse movimento, a sociedade (multissemiótica) coloca em cena práticas também múltiplas que passam a frequentar os vários espaços sociais, dentre eles, o espaço escolar. Conforme assinala Rojo (2009, p.119), essa nova realidade provoca a reflexão a respeito da leitura e da produção de textos de modo amplo, abrangendo:

[...] diversas linguagens e semioses (verbal oral e escrita, musical, imagética [imagens estáticas e em movimento, nas fotos, no cinema, nos vídeos, na TV], corporal e do movimento [nas danças, performances, esportes, atividades de condicionamento físico], matemática, digital etc.), já que essas múltiplas linguagens são constitutivas dos textos contemporâneos (grifo nosso).

A constituição do gênero texto dramático que buscamos discutir ao longo deste capítulo aponta para a possibilidade da cena e, por assim dizer, convoca para múltiplas semioses. Compreendemos, nesse sentido, que o desafio de nosso objeto de investigação no ensino de língua portuguesa relaciona-se a sua natureza multimodal. Em outras palavras, a produção escrita desse gênero discursivo permite-nos refletir as relações entre fala e escrita;

\footnotetext{
${ }^{28}$ Devido ao fato de sua natureza constituir-se estrutura e ação, observamos que o texto dramático pode estabelecer diálogo com outras teorias linguísticas, das quais destacamos: Pragmática, Semiótica e Análise da Conversação. Ressaltamos a pertinência dessas teorias, mas indicamos que nossa proposta tem por base os estudos da multimodalidade, arrolados neste capítulo.
} 
sua produção oral leva-nos a pensar em entonações e gestos que podem acompanhar as falas das personagens, seus movimentos e ações diante de um cenário proposto.

Entendemos que os estudos da multimodalidade e os estudos teatrais, arrolados neste capítulo, possibilitam-nos apontar para alguns direcionamentos, ao se pensar na natureza do gênero texto dramático:

a) Sua definição recobre uma relação de interdependência constitutiva:

i. Texto escrito como estruturante da representação cênica.

ii. Representação cênica como estruturada pelo texto escrito.

b) Suas possibilidades de interlocução revelam direcionamentos específicos:

i. Dramaturgo escreve para leitor literário, leitor-ator, leitor-diretor, público.

ii. Personagem atua com outra personagem e para o público.

c) Seus planos de produção (de linguagem) apontam para as modalidades:

i. Escrita (sequências tipológicas: conversacional e descritiva).

ii. Oral e outras semioses (entonação, ação, gestos, olhares etc.).

Ao se pensar a escola como uma importante agência de multiletramentos (ROJO, 2012), parece-nos significativo conhecer qual(is) a(s) concepção(ões) de texto dramático são convocadas para o ensino de língua portuguesa. Levando em consideração que o acesso à leitura nas escolas públicas brasileiras dá-se por meio de livros didáticos (RODRIGUES, 2007; BATISTA; ROJO; ZÚÑIGA, 2008) e que esse material (único ou suplementar) pode encaminhar a proposta pedagógica do professor em sala de aula (VAL; MARCUSCHI, 2008), buscamos apreender a versão escolarizada desse gênero discursivo em manuais de ensino de língua materna, assunto sobre o qual passamos a discorrer no próximo capítulo. 


\section{CAPÍTULO III}

\section{O texto dramático em livros didáticos de língua portuguesa}

Em cena, não corram por correr, nem sofram por sofrer. Não atuem de modo vago, pela ação simplesmente, atuem sempre com um objetivo.

Constantin Stanislavski

Este capítulo visa a refletir em torno da presença do texto dramático em manuais de ensino de língua portuguesa. A discussão constrói-se a partir da observação do que a versão escolar - evocada por unidades didáticas que abordam o texto dramático - revela-nos a respeito desse objeto de estudo, tendo em vista seu estatuto no campo teórico - gênero multimodal -, apresentado no capítulo II. Na primeira seção, explicitamos o conjunto de dados que conformam esta etapa da pesquisa.

\subsection{Apresentação do material didático}

O critério de seleção de nosso material dá-se em anuência à aprovação de coleções didáticas pelo Programa Nacional do Livro Didático - PNLD (BRASIL, 2010), para o Segundo Ciclo do Ensino Fundamental, correspondentes ao triênio 2011-2013. Em poucas palavras, o PNLD tem por objetivo "a aquisição e a distribuição, universal e gratuita, de livros 
didáticos para os alunos das escolas públicas do ensino fundamental brasileiro" (BATISTA, 2003, p.25-26). Para assegurar a qualidade dos livros a serem adquiridos, o Programa desenvolve, desde 1996, um processo de avaliação pedagógica das obras inscritas. As coleções recomendadas compõem, assim, um Guia, que é distribuído às escolas, para que estas possam efetuar sua escolha.

A leitura das resenhas das dezesseis (16) coleções aprovadas pelo $\mathrm{Guia}^{29}$ permitiu-nos observar a presença do texto dramático como conteúdo programático previsto para os anos finais do ensino fundamental $-8^{\text {os }}$ e $9^{\text {os }}$ anos. Esse dado ajudou-nos a estabelecer o recorte de nosso material, qual seja: livros didáticos que apresentam o texto dramático nessas séries escolares, necessariamente. Selecionamos, então, seis (06) livros didáticos voltados ao $8^{\circ}$ ano e dois (02) destinados ao $9^{\circ}$ ano, publicados entre 2008 e 2010.

Somam-se, assim, oito (08) livros didáticos a serem observados. No Quadro 2, a seguir, apresentamo-los - informando título e série a que se destinam - e indicamos as páginas das respectivas unidades didáticas (ou capítulos) que focalizam como estudo o texto dramático; do Quadro 2 - "Livros didáticos analisados" constam também os autores, a cidade, a editora e o ano em que cada obra foi publicada.

${ }^{29}$ www.fnde.gov.br/index.php/pnld-guia-do-livro-didatico/2349-guia-pnld-2011. 
Quadro 2 - Livros didáticos analisados

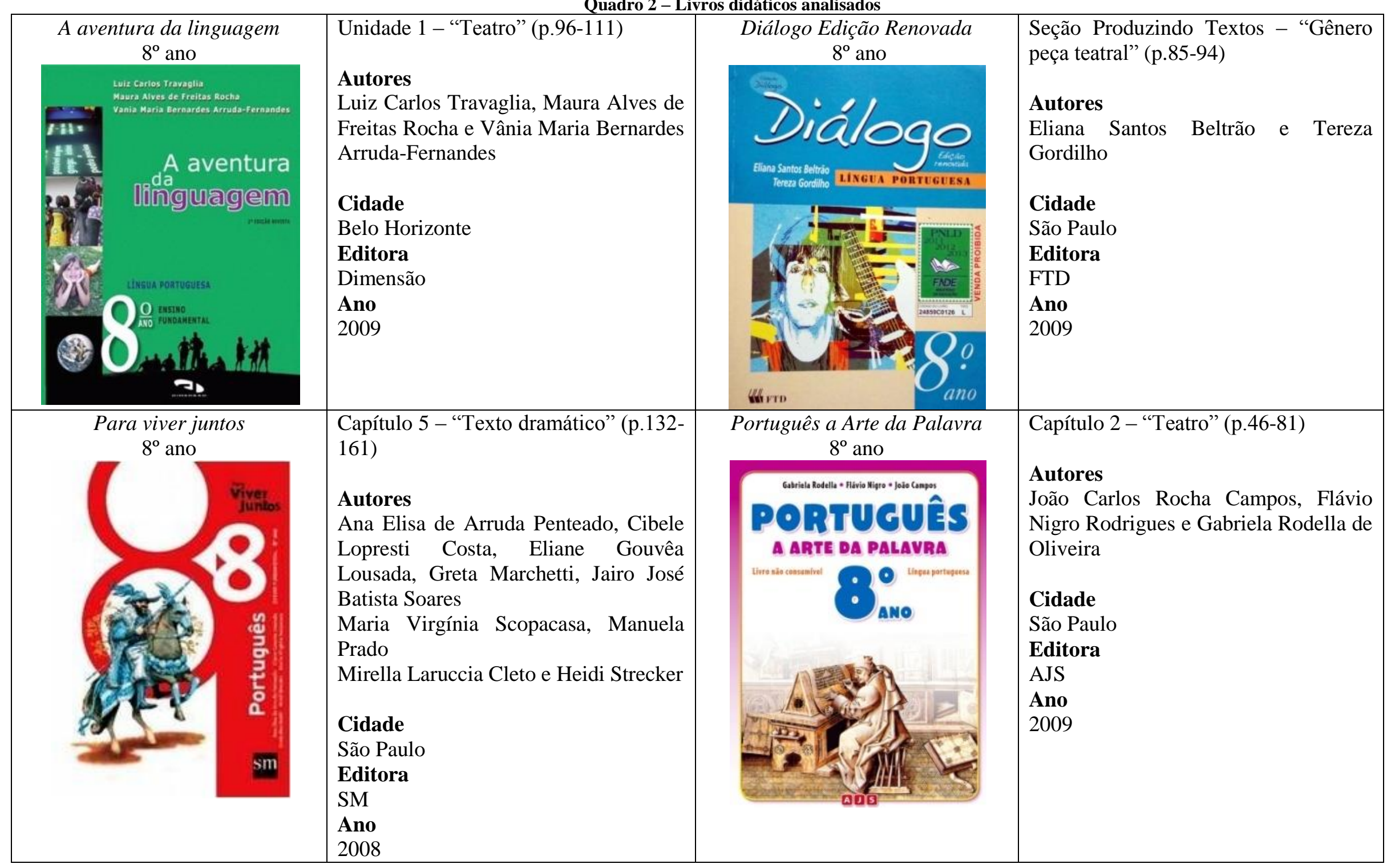




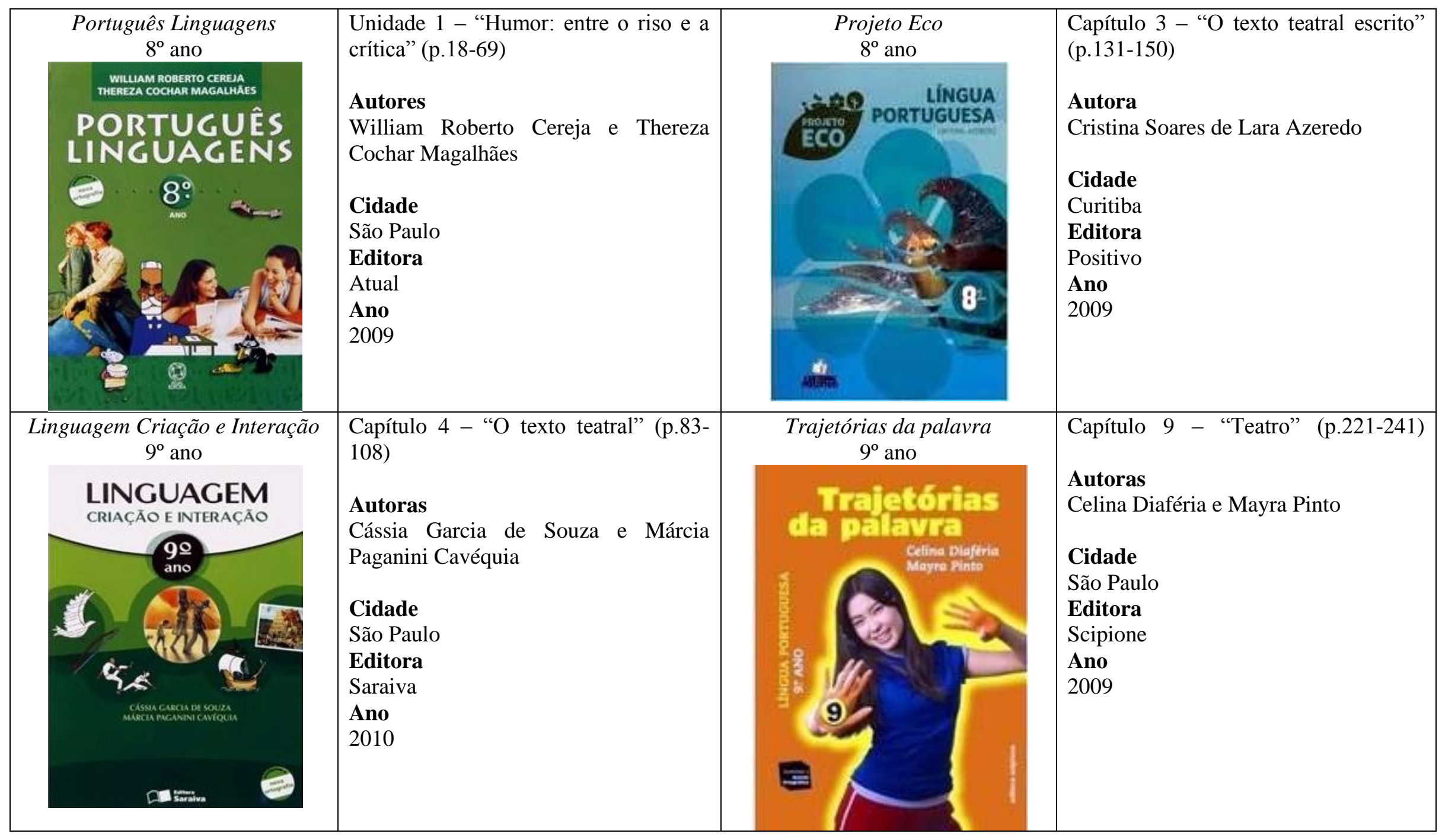


Para observação desse conjunto de dados, tomamos como fio condutor o desafio (multimodal) da escolarização do texto dramático, e passamos a refletir em torno da maneira como o objeto de ensino é apresentado ao aluno nas unidades didáticas selecionadas, das concepções de texto dramático que evocam da observação de perguntas alocadas na seção "estudo do texto" e das propostas de atividades para produção escrita e oral do texto dramático. Tais propósitos levaram-nos a estabelecer três (03) categorias de análise:

(1) Abertura do capítulo.

(2) Atividades de leitura e compreensão de textos.

(3) Propostas de produção escrita e oral.

A seleção dessas categorias encontra respaldo no procedimento metodológico "análise documental”, conforme asseguram Lüdke e André (1986, p.42):

Depois de organizar os dados, num processo de inúmeras leituras e releituras, o pesquisador pode voltar a examiná-los para tentar detectar temas e temáticas mais frequentes. Esse procedimento, essencialmente indutivo, vai culminar na construção de categorias ou tipologias. A construção de categorias não é tarefa fácil. Elas brotam, num primeiro momento, do arcabouço teórico em que se apoia a pesquisa (grifo nosso).

Tendo em vista essas considerações, passamos a explicitar cada uma das categorias anteriormente mencionadas.

\subsubsection{Abertura do capítulo}

A abertura do capítulo de um livro didático se presta, a nosso ver, a inserir o aluno em um novo ambiente de estudo, preparando-o para a proposta que está por vir. Esse momento parece-nos significativo na medida em que se constitui o primeiro contato que o aluno estabelece - via livro didático - com o conteúdo (o saber) a ser discutido em sala de aula; em 
uma palavra, a abertura do capítulo identifica-se como a instância que possibilita a sensibilização para o objeto de estudo. Nesse sentido, lembra-nos, por um lado, o exórdio da Retórica de Aristóteles - em que o orador deveria apresentar um preâmbulo quanto ao que ia ser discutido - e, por outro, a etapa denominada "apresentação da situação", sugerida pelos pesquisadores genebrinos, adaptada em nossa proposta de sequência didática, sob o título "Módulo 1 - Presentificação do Objeto de Ensino 30 ".

A leitura e a observação das páginas que iniciam cada material sob análise permitemnos afirmar que os livros didáticos fazem uso desse recurso de forma abundante e plural, revelando finalidades distintas, que apontam para:

a) Ativação do conhecimento prévio a respeito do objeto de ensino.

b) Proposição de atividades em torno do objeto de ensino.

c) Definição e topicalização do objeto de ensino.

Pontuamos que as oito (08) unidades didáticas selecionadas para esta pesquisa atendem ora a uma, ora à outra finalidade. Diante disso, buscamos apresentar alguns exemplos que revelem - na abertura dos capítulos sob análise -, como o objeto de ensino é apresentado ao aluno e, sobretudo, se tais propostas sinalizam, de algum modo, a natureza multimodal do texto dramático. Para análise dos itens (a), (b) e (c), procedemos à indicação do livro didático, seguido da descrição da atividade proposta.

a) Ativação do conhecimento prévio a respeito do objeto de ensino

Nestes casos, a abertura do capítulo dá-se a partir de perguntas direcionadas ao aluno, para que ele possa expor, oralmente, sua experiência com o teatro ou aquilo que, no bojo desta esfera, parece-lhe conhecido, familiar. Apresentamos, a seguir, algumas atividades propostas pelas unidades didáticas sob análise que caminham para essa direção.

${ }^{30}$ Cf. Capítulo I (p.43). 


\section{- Projeto Eco (2009)}

O Projeto Eco (2009) apresenta uma seção inicial dedicada para o conhecimento do que o aluno sabe a respeito do universo teatral, intitulada "Troca de ideias", que destacamos a seguir:

- Você já foi ao teatro alguma vez? Se não, assistiu a uma peça em outro ambiente, como a escola, por exemplo?

- Alguma vez teve oportunidade de participar de uma peça teatral? Em caso afirmativo, conte como foi a experiência.

- Já leu uma peça teatral? Qual o título e o tema da peça?

- $\quad[\ldots]$

- Em sua opinião, o que torna o teatro diferente do cinema ou da televisão?

Projeto Eco (2009, p.131)

Da observação dos elementos linguísticos presentes nas perguntas formuladas, depreendem-se sintagmas verbais indicativos de movimento, como: ir ao teatro, assistir a uma peça de teatro, participar de uma peça, que apontam para a intrínseca relação texto dramático (objeto de estudo da unidade didática) e seu plano de produção oral.

Já a penúltima questão elaborada pelo Projeto Eco (2009, p.131) instiga o aluno a dizer sobre sua experiência na leitura de uma peça, “Já leu uma peça teatral? Qual o título e o tema da peça?", sinalizando, nessa direção e, em meio às demais referências sobre representação, a ocorrência da produção escrita do texto dramático.

Observamos, assim, que a apresentação do objeto de ensino, nessa unidade didática, constrói-se no cotejo de suas manifestações escrita e oral. Por um lado, o aluno é convidado a rememorar experimentações relacionadas à representação cênica, por outro, possibilidades de seu contato direto com a materialidade textual.

Entendemos que, em sua maioria, as perguntas alocadas na abertura desse capítulo buscam conhecer o que o aluno já sabe a respeito do objeto de ensino proposto pela unidade didática. Ainda na proposta do Projeto Eco (2009, p.131), questiona-se: "Em sua opinião, o que torna o teatro diferente do cinema ou da televisão?”. Trata-se, pois, de um 
questionamento que instiga o aluno a refletir sobre o que ele sabe, mesmo que intuitivamente, a respeito da esfera artística/teatral, ao comparar diversas práticas sociais.

\section{- Português a Arte da Palavra (2009)}

Há casos em que as perguntas que compõem a abertura do capítulo remetem, exclusivamente, a textos escritos, como em Português a Arte da Palavra (2009, p.47), que apresenta um fragmento de um guia publicado na Folha de São Paulo, contendo sinopses de peças teatrais que estiveram em cartaz no ano de 2009. Na sequência, questiona-se: "Que informações você pode obter lendo as sinopses das peças acima?", "Você sabe quantas pessoas estão envolvidas numa encenação teatral?’”.

A partir da leitura de sinopses que reportam informações sobre a representação cênica, procura-se saber o conhecimento que o aluno possui a respeito do teatro, especialmente, quanto aos componentes presentes em uma encenação.

\section{- Linguagem Criação e Interação (2010)}

$\mathrm{Na}$ abertura das unidades didáticas, o recurso imagético também é vastamente empregado para ativação do conhecimento prévio do aluno a respeito do objeto de ensino proposto. No livro Linguagem Criação e Interação (2010), há uma imagem de uma atriz interpretando a personagem Sra. Martin, na peça "O banquete performático", adaptação livre da obra "A cantora careca", de Eugéne Ionesco (Imagem 1). 


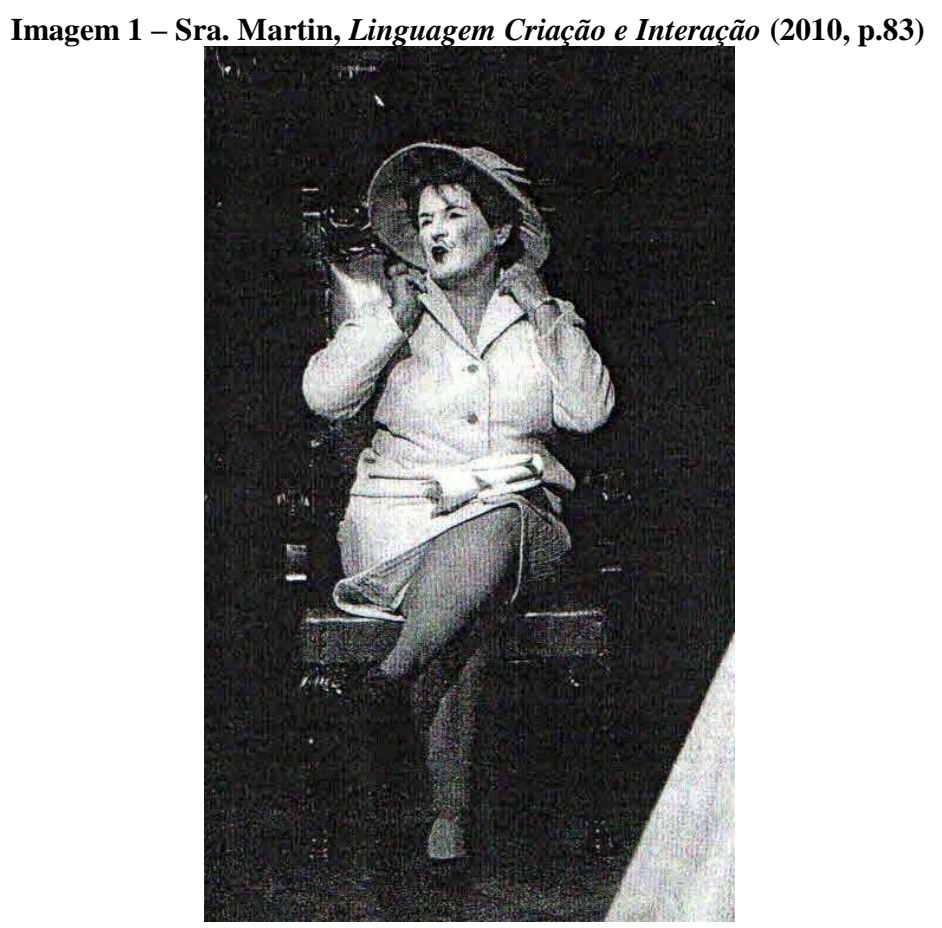

As perguntas dirigidas aos alunos buscam apreender o que eles sabem a respeito do teatro, enquanto representação cênica: "Para que uma peça teatral seja encenada, o que você imagina que seja necessário?", "Em sua opinião, qual a finalidade do teatro?”, perguntas estas que buscam discutir, por exemplo, os elementos fundamentais de uma encenação: atores, texto, plateia, cenário, figurino, sonoplastia, diretor etc.; e, ainda, os propósitos aí instaurados: diversão, crítica, formação de opinião, reflexão etc.

\section{- Para viver juntos (2008)}

O capítulo de Para viver juntos (2008) também faz uso da imagem, a fim de iniciar a discussão em torno do teatro; neste caso, a ênfase é dada ao espaço físico em que o espetáculo se apresenta. As páginas que servem para a abertura desse capítulo apresentam a imagem de uma Ópera, espécie de obra dramática musicada por uma orquestra (Imagem 2). 


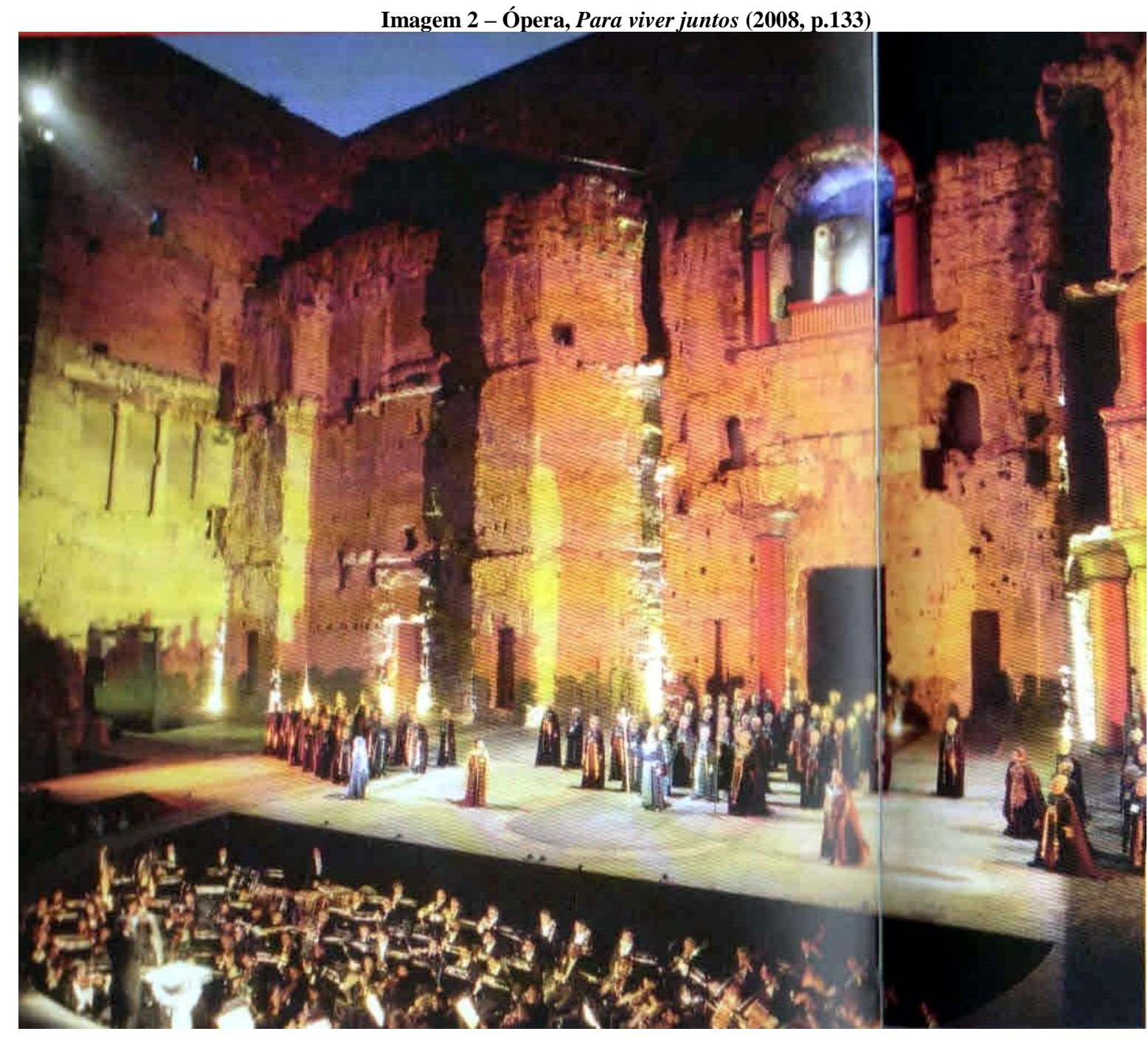

Ao lado da imagem, há perguntas que buscam fazer o aluno pensar a respeito da situação em foco, imaginar o que poderia acontecer naquele espaço: "Que elementos podemos identificar na imagem ao lado?”, “A presença desses elementos sugere que tipo de espaço?”, "Que tipo de atmosfera o cenário, a caracterização das personagens e a iluminação do palco sugerem?”, "Que tipo de espetáculo parece estar sendo representado?”.

\section{- Trajetórias da palavra (2009)}

Em Trajetórias da palavra (2009), há, também, a leitura de imagens, no entanto, sem perguntas correspondentes. A primeira imagem apresenta-se em preto e branco e corresponde 
a uma cena do seriado "O bem-amado", do teatrólogo brasileiro Dias Gomes, exibido entre os anos 1980 e 1984; a segunda diz respeito a uma cena da primeira novela exibida em cores no Brasil, em 1973, “O bem-amado" (Imagem 3):

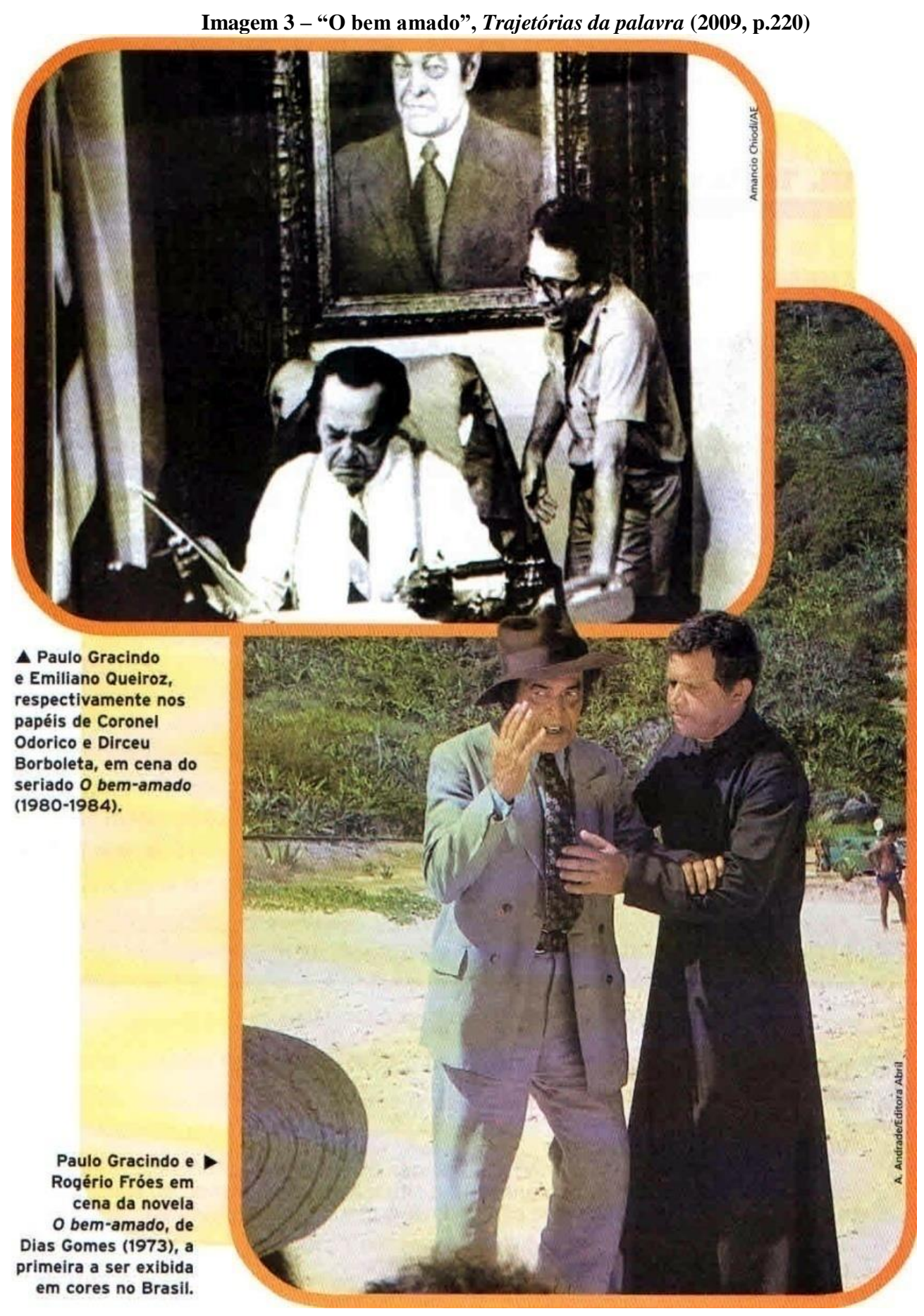


Esses três últimos livros mencionados (Linguagem Criação e Interação, Para viver juntos e Trajetórias da palavra) apresentam, conforme observamos, imagens voltadas ao universo teatral que se deseja conhecer. Os alunos são confrontados com tais imagens e levados a verbalizar aquilo que sabem a respeito desse conteúdo. As perguntas que acompanham tais imagens constituem-se bastante semelhantes, pois focalizam o espaço físico (teatro), os participantes da representação e suas performances (atores/personagens) e os componentes necessários para encenação (cenário, figurino, iluminação etc.).

O exposto permite-nos afirmar que as unidades didáticas analisadas apresentam o objeto de ensino - texto dramático -, inserindo-o na esfera artística/teatral, na mobilização de percepções a respeito da representação cênica (ou encenação, peça de teatro), e na seleção de textos que circulam e informam sobre essa prática discursiva (sinopses e imagens).

No próximo item (b), descrevemos a continuidade da proposta de abertura do capítulo de Trajetórias da palavra (2009), que sugere, também, a realização de jogos teatrais.

\section{b) Proposição de atividades em torno do objeto de ensino}

$\mathrm{O}$ exemplo que segue consiste da página seguinte à imagem da cena de "O bem amado", descrita anteriormente, em que se promove a realização de atividades relacionadas à esfera teatral.

\section{- Trajetórias da palavra (2009)}

Em Trajetórias da palavra (2009, p.221), as autoras dirigem-se diretamente ao aluno, a partir da seleção do pronome "você": "Nesta atividade você será o ator/a atriz!". Observamos a direção dada à atividade "será o ator/ a atriz", que procura contemplar os dois gêneros (alunos e alunas) e a presença da exclamação, que parece atribuir um sentido positivo a este exercício. Em seguida, o comando dá a possibilidade de o aluno escolher entre dois jogos para realizar uma encenação. Há uma observação ao final: “Lembre-se de que, durante a 
apresentação, todos devem permanecer em silêncio" - enunciado que remete ao comportamento social esperado de quem assiste a uma encenação.

A primeira opção de jogo é a mímica. O exercício sugere aos alunos que encenem uma situação somente por meio de gestos, enquanto isso, os outros alunos devem registrar o que foi encenado no caderno. O segundo jogo corresponde a uma ampliação do primeiro, trata-se da encenação, por meio de dois estímulos: os gestos e a verbalização de frases ditas a partir de uma língua inexistente. Este exercício, como o primeiro, também solicita aos alunos que registrem no caderno o presenciado e que anotem o que foi entendido durante a encenação do colega.

A observação desse início de capítulo permite-nos detectar que a sensibilização para o texto dramático dá-se por meio de atividades arraigadas na esfera teatral - a mímica, a blablação $^{31}$, por exemplo. Pode-se verificar, também, que as ações descritas pelo comando da atividade são ritualizadas, de modo a ser possível a apreensão das ações dos participantes envolvidos nesse tipo de interação: há alguém que se apresenta e este alguém é denominado "ator" ou "atriz" e há também outras pessoas que assistem - a plateia. Ao primeiro grupo de pessoas, cabe a função de fazer uso de gestos e/ou vocalizações e, ao segundo, a função é compreender e avaliar.

Os jogos sugeridos levam-nos a pensar a respeito da maneira como o saber em torno do texto dramático parece ter sido escolarizado nessa unidade didática; neste caso, a presentificação do objeto de ensino ocorre por meio de atividades que convidam os alunos a exercitar outras semioses (ações/gestos). A atividade proposta investe, assim, no eixo performático e convoca múltiplos modos de produção de linguagem: o aluno pode levantar-se, agir, movimentar o corpo, expressar-se de algum modo para comunicar algo.

A abertura do capítulo dos livros didáticos sob análise configurou-se, também, a partir da sumarização da proposta, conforme indicamos no item (c), a seguir.

\footnotetext{
${ }^{31}$ Segundo Spolin (2010, p.179), “a blablação é a substituição de palavras por sons. Não deve ser confundida com linguagem confusa, em que palavras são invertidas ou mal pronunciadas [...]. O significado de um som em blablação será compreendido somente quando o jogador se comunicar por ações e expressões ou tom de voz".
} 
c) Definição e topicalização do objeto de ensino

$\mathrm{Na}$ abertura dos capítulos, observamos que houve, ainda, uma preocupação com introduzir os conteúdos e as características constitutivas do objeto de estudo. Na maioria dos casos, encontra-se a explanação teórica em torno do texto dramático ou da esfera teatral, conforme passamos a observar:

\section{- A aventura da linguagem (2009)}

A unidade didática do livro A aventura da linguagem (2009, p.96) inicia-se com um texto informativo, que ocupa uma página inteira, a respeito da arte dramática. Nele, o texto dramático é definido como um roteiro que contém o enredo, os diálogos e as orientações para que a história seja bem encenada - as rubricas -, "que informam sobre o cenário, o modo de falar dos personagens, os movimentos e gestos dos atores, suas roupas e maquiagem”.

\section{- Diálogo Edição Renovada (2009)}

Na direção da proposta anterior, a abertura do capítulo de Diálogo Edição Renovada (2009, p.85) define texto dramático como "texto escrito ou encenado, composto em forma de diálogos e rubricas" e, na sequência, explicita que nesse texto "não há narrador, e cabe ao leitor ou espectador inferir as características de cada personagem e compreender os conflitos a partir da maneira como falam e agem".

Os excertos "texto escrito ou encenado", "cabe ao leitor ou espectador" ajudam-nos a observar a confluência dos planos de produção do texto dramático em sua própria definição; pode ser entendido em sua natureza escritural ou em sua natureza oral e multimodal, pois convoca para a interação um leitor ou um espectador (ler, ouvir, ver). 
Além disso, observamos, nas duas propostas descritas (A aventura da Linguagem e Diálogo Edição Renovada), a identificação das sequências tipológicas que compreendem a produção escrita do texto dramático - descritiva (presença de rubricas) e conversacional (presença de diálogos). Essa composição heterogênea do texto dramático vai ao encontro dos postulados dos estudiosos do teatro (RYNGAERT, 1995; PAVIS, 2008; UBERSFELD, 2010), discutidos no capítulo II deste trabalho.

- Para viver juntos (2008)

Em Para viver juntos (2008), há um boxe que explicita o gênero a ser estudado, conforme segue:

Já na Grécia antiga o teatro enlaçava atores e público em um pacto de cumplicidade, permitindo um estreitamento entre os limites da realidade e da ficção e possibilitando que, pela arte da representação, os espectadores experimentassem enorme gama de sentimentos. Desde então, as artes cênicas vêm sendo usadas para divertir, emocionar, denunciar algo e provocar reflexão. Neste capítulo, vamos estudar as principais características do texto dramático, aquele que estrutura todo espetáculo teatral.

Para viver juntos (2008, p.133), grifo nosso.

A leitura do excerto permite depreender a concepção de teatro enquanto manifestação artística, para, então, apresentar o texto dramático (escrito) - objeto de estudo da unidade didática - como estruturante da representação cênica, "aquele que estrutura todo espetáculo teatral". A concepção de texto dramático evocada nesse livro didático parece-nos indicar a relação estreita entre a construção escritural do texto teatral e a representação cênica, posição corroborada por estudiosos do teatro (GRÉSILLON, 1995; CALZAVARA, 2009). 


\section{- Português a Arte da Palavra (2009)}

Em Português a Arte da Palavra (2009), a abertura do capítulo faz-se com a enumeração dos tópicos a serem abordados, conforme indicamos a seguir:

\section{Neste capítulo vamos:}

Ler cenas de peças e rever como se estrutura um texto teatral;

Conhecer as funções de todos os envolvidos em uma encenação;

Estudar a resenha crítica;

Escrever resenhas críticas, improvisar cenas, encenar uma peça;

Aprender sobre as frases com período simples e período composto, e também sobre as orações coordenadas.

Português a Arte da Palavra (2009, p.46)

A proposta de estudo desse livro didático parece evidenciar as práticas discursivas/sociais que o texto dramático pode colocar em cena ao ser escolarizado: o aluno é convidado, por exemplo, a ler peças, reconhecer sua estrutura, improvisar cenas, encenar uma peça, conhecer aqueles que estão envolvidos em uma encenação. Em uma palavra, as ações requeridas ao longo dessa unidade didática sinalizam o desafio multimodal no ensino desse gênero discursivo, ao combinar fala e escrita a outras semioses.

Em síntese, a análise dos itens anteriormente apresentados, (a), (b), (c), permite-nos afirmar que, ao ser sensibilizado por meio das sugestões propostas nas páginas de abertura das unidades didáticas (ativação do conhecimento prévio, proposição de atividades, definição do objeto de ensino), o aluno começa a interagir com o gênero escolarizado. Para tanto, o tratamento didático dispensado ao texto dramático busca relacioná-lo à prática social que o engendra - o teatro.

A próxima seção visa a observar os textos selecionados pelos livros didáticos para o estudo do texto dramático e as atividades que se destinam a esse fim. As análises dessa categoria procuram evidenciar a concepção de texto dramático dos livros didáticos, a partir das perguntas relacionadas à leitura e compreensão textual. 


\subsubsection{Atividades de leitura e compreensão de textos}

A maioria dos livros didáticos sob análise apresenta textos dramáticos utilizados como referência para nortear as atividades de leitura e compreensão textual, conforme destacamos, a seguir (Imagens 4, 5 e 6):

Imagem 4 - Texto de referência (fragmento), Para viver juntos (2008, p.134)

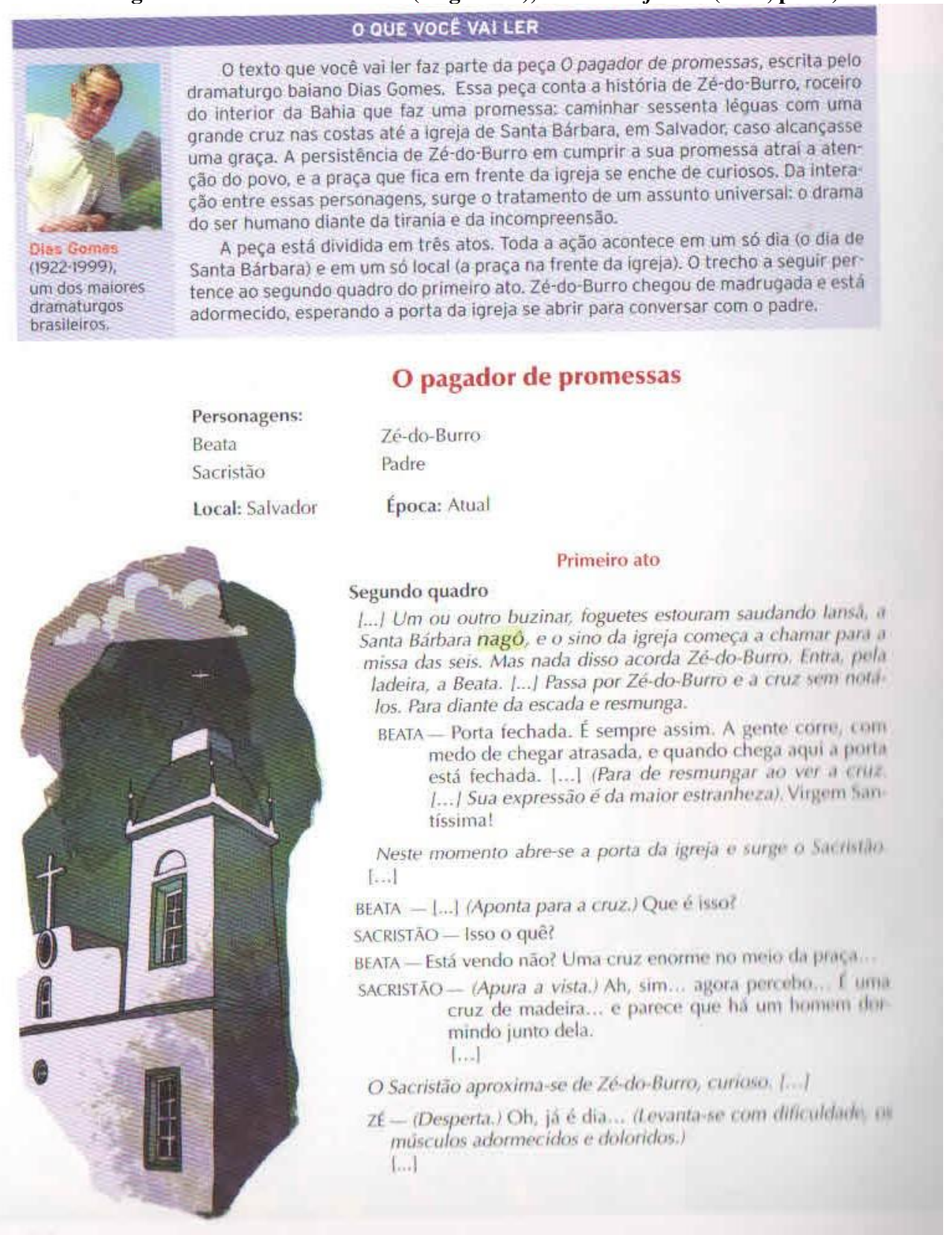


A pequena e fictícia cidade de Sucupira não possuía um cemitério, de modo que os habitantes precisavam enterrar seus mortos nas cidades vizinhas. Com a promessa de construir um cemitério na cidade, Odorico Paraguaçu foi eleito prefeito. Mas eis que surge um novo problema: mais de um ano após sua construção, o cemitério ainda não havia sido inaugurado, pois nenhuma morte ocorrera na cidade desde então. Pressionado pelos adversários políticos, que o acusavam de empregar indevidamente os recursos públicos, Odorico empenha-se em resolver o problema. Leia a seguir um trecho da obra da qual faz parte essa personagem.

\section{O Bem-Amado Terceiro Quadro}

Odorico lê um exemplar de A Trombeta, o jornaleco local. Seu rosto revela profunda indignação.

Odorico (Resmunga, enquanto lê.) Patife! CanaIha! (Amarrota o jornal violentamente e atira-o ao chão. Põe-se a andar nervosamente de um lado para o outro, $e$ por fim senta-se à sua mesa, parecendo a ponto de ter um colapso.)

Dorotéa (Entra quase marcialmente.) Bom-dia, senhor prefeito.

Odorico Bom-dia. (Levanta-se de um salto.) A senhora já leu a gazeta?

Dorotéa Ainda não.

Odorico Esse patifento desse Neco Pedreira me chama de demagogo esbanjador dos dinheiros públicos... me xinga de tudo quanto é nome. (Apanha o jornal.) Leia a senhora mesma, leia.

Dorotéa Que retrato é esse que ele botou na primeira página?

Odorico É um retrato que tiraram de mim durante a construção do cemitério. Tem um ano, já.

Dorotéa (Lendo.) "Odorico, o pastor de urubus."

Odorico Que é que eu faço com um mau-caratista como esse, Dona Dorotéa? Que é que eu faço? Já pensei em arranjar dois jagunços e mandar dar uma surra...

Dorotéa Isso me parece contraproducente; vai fazer dele um herói e aumentar a venda do pasquim. Além do mais, o senhor teria que mandar surrar muita gente. A oposição está ganhando terreno dia a dia. E o que Neco escreveu n'A Trombeta é mais ou menos o que os nossos inimigos dizem por aí.

demagogo: político inescrupuloso que se vale dos desejos e necessidades populares para interesses próprios. jagunços: valentōes que se colocam a serviço de quem os paga para praticar, muitas vezes, crimes.

contraproducente: algo que produz resultado contrário ao que se esperava.

pasquim: jornal difamador. 
Imagem 6 - Texto de referência (fragmento), Português Linguagens (2009, p.18)

Você vai ler a seguir um fragmento da peça teatral Lua nua, de Leilah Assunção, que foi encenada em várias cidades do país entre 1986 e 1989, sempre com grande sucesso de público e de crítica.

A peça conta a história do casal Lúcio, um engenheiro, e Sílvia, uma advogada. Eles estão casados há alguns anos e têm um bebê, o Júnior. Na manhã retratada na cena reproduzida, eles enfrentam um sério problema: ambos têm uma entrevista importante, que decidirá o futuro profissional de cada um, e Dulce, a empregada, acabou de ser demitida por Sílvia, e agora não há quem fique com o bebế Como irão resolver esse problema?

\section{Lua nua}

Silvis É... O que é que a gente vai fazer?

Lucio E um problema mesmo... So que estou atrasadissimo, depois você me liga para dizer como é que resolveu por hoje.

Siıvia Espera ai, Lucio. Acho que vocé não entendeu ainda. A saida da Dulce é um problema nosso e não apenas meu.

Lúcio Mas foi você que despediu a moça, você causou o problema, agora resolva você, ora.

Stivia Ela extrapolou todos os limites, poderia ter sido com voce, e como se ela tivesse... pedido demissaao. E um problema da nossa casa, a ser resolvido, portanto, conjuntamente.

Lucio So que eu tenho a entrevista com os americanos às dez e meia e estou atrasado.

Sitvia Mas eu também tenho uma entrevista às dez e meia.

Lucio Ah, vocé nảo vai querer me comparar agora essa sua entrevista com o meu trabalho, vai?

Os exemplos destacados permitem-nos afirmar que os textos dramáticos apresentados pelas unidades didáticas são antecedidos, em geral, por textos introdutórios, para contextualizar temática, autor, enredo, personagens, contexto de produção da peça etc.; e acompanhados, também, por ilustrações (imagem do autor, desenhos estilizados do cenário ou das personagens) e glossário. Observamos, assim, que o paratexto é empregado para dar suporte ao objeto de estudo proposto pelo livro didático.

Para dar sequência a nossa discussão, indicamos o Quadro 3, que sintetiza os títulos e a quantidade de textos dramáticos disponibilizados nos livros didáticos sob análise: 
Quadro 3 - Textos dramáticos disponibilizados nos livros didáticos

\begin{tabular}{|c|c|c|c|}
\hline Livros didáticos & Quantidade & Título dos textos dramáticos & Outros $^{32}$ \\
\hline \multirow{2}{*}{ A aventura da linguagem } & \multirow{2}{*}{02} & Pan-americano & \multirow{2}{*}{01} \\
\hline & & A verdadeira história de Cinderela & \\
\hline Diálogo Edição Renovada & 01 & Um caso estranho & 01 \\
\hline \multirow{3}{*}{ Português a Arte da Palavra } & \multirow{3}{*}{03} & Coronel de Macambira & \multirow{3}{*}{04} \\
\hline & & A megera domada & \\
\hline & & Mire Veja & \\
\hline Português Linguagens & 01 & Lua nua & \\
\hline \multirow{2}{*}{ Projeto Eco } & \multirow{2}{*}{02} & O jogo de prendas & \\
\hline & & Auto da Compadecida & \\
\hline \multirow{2}{*}{$\begin{array}{lll}\begin{array}{l}\text { Linguagem } \\
\text { Interação }\end{array} & \text { Criação } & e \\
\end{array}$} & \multirow{2}{*}{02} & O bem-amado & \multirow{2}{*}{03} \\
\hline & & Teatro do absurdíssimo & \\
\hline \multirow{2}{*}{ Para viver juntos } & \multirow{2}{*}{02} & O pagador de promessas & \\
\hline & & A aurora da minha vida & \\
\hline \multirow{2}{*}{ Trajetórias da palavra } & \multirow{2}{*}{02} & O bem-amado & \multirow{2}{*}{01} \\
\hline & & Amor em anexins & \\
\hline
\end{tabular}

Com uma média de dois textos por capítulo (ou unidade didática), os textos são assinados, predominantemente, por autores do cânone da dramaturgia brasileira, como Dias Gomes (Imagens 4 e 5, evidenciadas anteriormente), Artur Azevedo, Martins Pena, Ariano Suassuna e Joaquim Cardozo. Há, também, autores contemporâneos, como Jô Soares, Gabriela Rabelo, Naum Alves de Souza, Pedro Pires, Zernesto Pessoa e Leilah Assunção (Imagem 6, também em destaque). O dramaturgo inglês William Shakespeare aparece na tradução de Millôr Fernandes.

A seleção desses textos leva-nos a compreender que os livros didáticos instituem o cânone literário como prática discursiva de referência para o ensino do texto teatral escrito. Nessa direção, apoiamo-nos em Dolz, Scnheuwly e Haller (2004) que destacam o fato de que o trabalho com os gêneros em sala de aula requer a observação de textos de referência, pois se trata de um objeto estável. Para os autores,

Os gêneros escolares podem ser considerados variantes dos gêneros de referência, que visam ser acessíveis ao aluno. Ele não é mais o mesmo, pois corresponde a um outro contexto comunicativo; somente ficcionalmente, ele continua o mesmo, por assim dizer, sendo a escola, de um certo ponto de vista, um lugar onde se finge, o que é, aliás, uma eficiente maneira de aprender (DOLZ; SCHNEUWLY; HALLER, 2004, p.150).

\footnotetext{
32 Os livros didáticos apresentam outros gêneros discursivos para subsidiar o trabalho com o texto dramático: conto, crônica, microcrônica, notícia e resenha crítica. Há, também, a presença de gêneros pertencentes à esfera teatral: cartazes, sinopses e programas de peças de teatro.
} 
Depreende-se dessa afirmação que o gênero trabalhado na escola, via livro didático, é uma variante do gênero de referência, (re)construído na situação de ensino e aprendizagem instaurada pela unidade didática. A esse respeito, Bunzen (2009) constata que os textos apresentados nos livros didáticos simulam a função "original” do gênero, já que são intercalados de modo constante pelo discurso do ensino; isto pode ser verificado por meio do emprego de paratextos, mencionado anteriormente.

No que diz respeito à extensão dos textos, apenas a peça "A verdadeira história de Cinderela", de Gabriela Rabelo, em A aventura da linguagem (2009), é publicada na íntegra, ocupando sete páginas e meia do capítulo. As demais peças apresentam-se em fragmentos com, no mínimo, duas e, no máximo, sete páginas. Publicadas na íntegra, mas com reduzida extensão, aparecem, também, a adaptação de um conto de mistério para teatro "Um caso estranho", em Diálogo Edição Renovada (2009), e o texto "Teatro do absurdíssimo", em Linguagem Criação e Interação (2010).

Entendemos que o uso de fragmentos de textos nos livros didáticos é efeito de sua escolarização, já que os textos dramáticos pertencentes ao cânone literário - empregados como gênero de referência - são extensos e, dificilmente teriam sua publicação na íntegra.

As atividades de leitura e compreensão de textos aparecem alocadas, geralmente, na seção $^{33}$ posposta ao texto dramático utilizado como referência. A observação das perguntas que compõem essas seções permitiu-nos identificá-las com base na concepção de texto dramático que evocam:

a) O texto dramático escrito é um texto narrativo ${ }^{34}$ e pertence à esfera literária.

b) Ainda que o texto dramático escrito seja um texto narrativo, ele apresenta uma estrutura composicional diferenciada dos outros textos narrativos.

c) O texto dramático escrito convoca a uma encenação.

\footnotetext{
${ }^{33}$ Nominada de diversas formas nos livros didáticos pesquisados, a mais utilizada é "Estudo do texto", mas encontramos outras denominações, como "O texto em estudo" e "Linhas \& entrelinhas".

${ }^{34}$ Esclarecemos que, para as discussões que se fazem presentes neste trabalho, a expressão "texto narrativo" correlaciona-se a gêneros pertencentes à ordem do narrar, conforme sugestão de agrupamentos dos gêneros, proposta por Schneuwly e Dolz (2004), incorporada, também, pelos PCN (BRASIL, 1998).
} 
É válido pontuar que essas concepções coexistem nas unidades didáticas sob análise e percorrem o todo correspondente às perguntas da seção "estudo do texto". Descrevemos, nos itens (a), (b) e (c), a seguir, a síntese dessas propostas.

a) O texto dramático é um texto narrativo e pertence à esfera literária

Devido ao fato de apresentar personagens que vivenciam uma história, desenvolvida em certo tempo e espaço, as atividades propostas nas unidades didáticas sob análise apontam para concepção de texto dramático como texto narrativo, situado na esfera literária.

A apresentação dos dados configura-se a partir da seleção de algumas perguntas que compõem a seção "estudo do texto" das unidades observadas e que têm por base elementos da narrativa, a saber: tempo e espaço, enredo e personagens (GANCHO, 2002).

\section{- Tempo e espaço}

“Em que época se passa a história?” - Para viver juntos (2008, p.136):

“Onde ocorre este fato?", "É possível indicar a época em que este fato ocorreu?" - A aventura da linguagem (2009, p.99)

"Onde ocorre essa cena?", "Qual é, aproximadamente, o tempo de duração dessa cena?" - Português Linguagens (2009, p.21)

\section{- Enredo}

"Qual é o fato desencadeador da história?" - Linguagem Criação e Interação (2010, p.88)

"O prefeito consegue construir o cemitério. O próximo passo é inaugurá-lo. Com qual obstáculo o prefeito se depara desta vez?" - Trajetórias da palavra (2009, p.230) 
"Petrúquio, na fala inicial, apresenta uma estratégia para conversar com Catarina. Qual era sua estratégia? Essa estratégia funcionou?" - Português a Arte da Palavra (2009, p.57)

"Como Lúcio se posiciona diante do problema que surgiu naquele dia?", "Pela reação de Sílvia, o que ela não quer mais?" - Português Linguagens (2009, p.20)

\section{- Personagens}

“Quais são os personagens da peça 'Pan-americano'?" - A aventura da linguagem (2009, p.99)

"Quanto ao prefeito Odorico, o que se pode dizer dele como político e administrador público?” - Linguagem Criação e Interação (2010, p.88)

"Há uma característica original no nome das personagens. Qual é ela?" Para viver juntos (2008, p.149)

Depreende-se que as perguntas centralizadas no tempo, espaço, enredo e personagens retomam os acontecimentos sequencialmente apresentados e, em geral, solicitam que o aluno volte ao texto para localizar tais informações. É possível afirmar que tais exercícios, estruturados com base nos elementos da narrativa, procuram evidenciar somente a história, isto é, "o quê" se conta. A observação das perguntas anteriormente destacadas permite-nos compreender que o tratamento didático conferido ao objeto de ensino texto dramático escrito faz-se a partir da abordagem literária do gênero.

Entremeadas a essas, outras perguntas de leitura e compreensão - apesar de situarem o texto dramático escrito como texto narrativo - indicam uma estrutura diferenciada daquela tipicamente encontrada em contos ou fábulas, por exemplo. É o que faremos observar no próximo item (b). 
b) Ainda que o texto dramático escrito seja um texto narrativo, ele apresenta uma estrutura composicional diferenciada dos outros textos narrativos

Ao longo das atividades de leitura e compreensão do texto dramático utilizado como referência para o ensino, nos capítulos sob análise, a concepção de texto dramático escrito se constrói no cotejo com a concepção de texto narrativo prototípico, por exemplo, a partir da identificação da ausência de narrador, por um lado, e da presença de narrador, por outro; da presença do diálogo e de rubricas.

\section{- Ausência de narrador}

A proposta da unidade didática de Português Linguagens (2009) discute o modo como a fala das personagens precisa ser introduzido no texto dramático, por este não apresentar marcas formais do discurso direto, comuns aos textos narrativos. Assim, temos:

Comparando a estrutura do texto teatral com a de outros textos narrativos, como, por exemplo, o conto, o mito, a fábula, observamos que o texto teatral se constrói de uma forma diferente.

- Há, no texto teatral, um narrador que conta a história?

- De que maneira, então, tomamos conhecimento dela?

O diálogo entre as personagens constitui o elemento essencial de um texto teatral. Numa fábula ou conto, a fala das personagens aparece geralmente depois de verbos como dizer, perguntar, afirmar, chamados dicendi.

- No texto teatral escrito, como é introduzida a fala das personagens? Português Linguagens (2009, p.21)

\section{- Presença de diálogos}

Ainda sob a perspectiva da comparação entre texto dramático escrito e texto narrativo, a atividade do livro Trajetórias da palavra (2009) também destaca o diálogo como elemento essencial do texto dramático: 
Esse é um trecho de uma peça teatral [O bem-amado, de Dias Gomes]. Sua forma é um pouco diferente de um trecho narrativo. Observe os seguintes aspectos e responda às questões:

- No texto há mais narração, descrição ou diálogos?

- Há narrador?

- Como sabemos qual personagem está falando?

Trajetórias da palavra (2009, p.229)

Essas três perguntas permitem-nos observar características que apontam para a estrutura composicional do texto dramático escrito, o qual difere um pouco de um trecho narrativo. Devido à habitual ausência do narrador, o texto dramático escrito constrói-se por meio de diálogos, antecedidos com o nome das personagens (para identificar quem está falando). Reforçam essa afirmação outras atividades, conforme destacamos:

"Na peça "Pan-americano", há um narrador? Como a história é contada?" - $A$ aventura da linguagem (2009, p.99)

"Não há um narrador para contar a história. Como os fatos são apresentados ao leitor? Como o leitor identifica a personagem que está falando?" - Para viver juntos (2008, p.136)

A atividade proposta pelo Projeto Eco (2009) promove, ainda, a descrição de outras possibilidades de apresentação das falas, além do diálogo. Assim, temos:

Réplica: é o discurso normal, habitual e sucessivo dentro do texto, em que o nome da personagem vem citado antes de cada fala.

Aparte: é o discurso do personagem dirigido para si mesmo ou para o público. Nesse caso, fica expresso que os demais personagens da cena não estão escutando o que está sendo dito.

Monólogo: é o discurso solitário do personagem, que, no momento dessa fala, está sozinho em cena.

Volte ao texto e localize os momentos em que podem ser observados o aparte e o monólogo.

Projeto Eco (2009, p.138) 


\section{- Presença de rubricas}

Algumas unidades didáticas buscam apresentar ao aluno a estrutura específica do texto dramático escrito (em comparação ao texto narrativo), marcado, essencialmente, pelo diálogo e por indicações que descrevem a localização, as ações ou sensações das personagens em determinada situação. É o caso do exercício sugerido em Diálogo Edição Renovada (2009):

Como você pôde perceber, o texto teatral caracteriza-se pela presença marcante de diálogo entre os personagens, ou seja, não existe um narrador relatando os fatos. Outra característica relevante é a descrição detalhada do espaço, do tempo e dos personagens, seu comportamento, gestos e expressões. A adaptação de um texto para o teatro (cinema ou televisão) exige, portanto, uma linguagem particular, recursos e procedimentos técnicos bem específicos. Agora responda:

- O que os trechos na CENA 1 e na CENA 2 descrevem e indicam para o leitor?

- Como estão indicadas as ações, os gestos, a entonação de voz de cada personagem?

- Na sua opinião, a ausência do narrador no texto teatral interfere no clima da história? Por quê?

Diálogo Edição Renovada (2009, p.91)

O enunciado que antecede às perguntas compreende que "o texto para o teatro utilizase de linguagem particular, recursos e procedimentos técnicos bem específicos". As características mencionadas remetem às indicações cênicas, empregadas no início de cada cena para descrever o cenário e as personagens e, ao longo do texto, para evidenciar ações, gestos e entonação de voz. Conforme revela a atividade, essas indicações podem estar entre parênteses, com um tipo de letra diferente (itálico, por exemplo).

Em Linguagem Criação e Interação (2010, p.88), busca-se ampliar o exercício de identificação de rubricas, de sua composição gráfica ou de sua finalidade, ainda em correlação ao texto narrativo: "Em que tempo e modo aparecem os verbos das rubricas?" e "Em um texto narrativo - como um conto, um romance, uma crônica, uma fábula - o que corresponde às rubricas?". A primeira questão sinaliza o emprego de verbos no presente do indicativo, que indicam as ações das personagens no instante da fala. Já a segunda, estabelece uma relação 
entre o papel das rubricas no texto dramático escrito e o papel (a voz) do narrador, ao descrever as personagens em outros gêneros da ordem do narrar.

O exposto permite-nos afirmar que os livros didáticos analisados visam a preconizar algumas propriedades do texto dramático escrito, ao considerar que sua forma se diferencia do texto narrativo. Assim, as unidades didáticas evidenciam: a frequente ausência do narrador, a presença de diálogos sequenciados (réplicas), monólogos e apartes - dispostos de maneira que o nome da personagem apareça antes de cada fala -, e a presença de rubricas, que podem ser identificadas por uma marcação gráfica diferenciada e revelar a maneira de se ler cada trecho.

Diante dos exemplos apresentados, é possível entender que a versão escolarizada do texto dramático escrito, evocada pelos livros didáticos analisados, parece inseri-lo na esfera literária, devido à recorrência à observação de elementos característicos dos textos narrativos (tempo, espaço, enredo e personagens); ao mesmo tempo, parece admitir, também, a existência de uma estrutura singular (diálogos e rubricas).

Intercaladas às perguntas já apresentadas nos itens (a) e (b), as atividades que promovem o estudo do texto dramático nas unidades didáticas observadas, apresentam, também, exercícios que buscam aproximar a relação de interdependência constitutiva entre texto dramático escrito e texto dramático oralizado/representado ${ }^{35}$. É o que nos propomos a discutir no item (c), a seguir.

c) O texto dramático escrito convoca a uma encenação

A concepção de texto dramático pressuposta nas atividades que ilustram este item aponta para relação de reciprocidade entre texto dramático e representação cênica, evidenciada em exercícios que buscam observar: a estrutura composicional (rubricas, cenas), o estilo do texto (recursos gráficos, alongamento de vogais, pontuação e repetição) e seu propósito comunicativo (encenação).

\footnotetext{
${ }^{35}$ Do ponto de vista teórico, tratamos desse assunto na seção 2.3 deste trabalho, capítulo II (p.59).
} 


\section{- Estrutura composicional}

Apresentamos, primeiramente, a atividade proposta em $A$ aventura da linguagem (2009), que procura explorar a presença das rubricas no texto dramático escrito, de modo a indicar sua função.

Além do diálogo dos personagens, que dá a conhecer o enredo e o tema da peça, o texto contém também indicações para sua encenação. Estas indicações são chamadas rubricas e geralmente aparecem de forma diferente (no texto que você leu, estão em itálico e entre parênteses). Localize, na peça de Artur Azevedo, as seguintes rubricas:

Rubricas cênicas - informam o local em que acontece a cena, como deverá ser constituído o cenário.

Rubricas de interpretação - descrevem o estado emocional dos personagens, orientando aos atores quanto ao modo de falar.

Rubricas de movimento - indicam os movimentos, gestos, posições dos atores.

A aventura da linguagem (2009, p.99)

O enunciado evidencia, já de início, o papel que as rubricas assumem no texto dramático escrito: "indicações para encenação". A função atribuída às rubricas revela uma característica própria da ordem do texto escritural que aponta para a performance teatral.

A questão que se apresenta a seguir objetiva estabelecer outra característica da estrutura composicional do texto dramático - as cenas. Trata-se da atividade proposta pela unidade didática de Trajetórias da palavra (2009):

No teatro, cena é cada uma das unidades de ação de uma peça. A divisão entre cenas é feita segundo as entradas e saídas dos atores.

- No trecho lido, há quantas cenas?

- Indique o início e o fim de cada uma delas.

Trajetórias da palavra (2009, p.230)

A discussão do conceito "cenas" é inserida no bojo da prática teatral, pois se identifica como "unidades de ação de uma peça" que sinalizam "entradas e saídas dos atores" (não das personagens). $\mathrm{Na}$ atividade proposta, o aluno utiliza-se do texto escrito para apreender o 
limite entre uma cena e outra, a partir da observação de sua disposição gráfica. Observamos, nessa direção, que a definição da macroestrutura do texto dramático escrito (organizado em cenas) parte, em primeira mão, também do entendimento da organização da própria encenação (entrada e saída dos atores). A movimentação que se busca dos atores determina a divisão do texto em cena; a representação cênica apresenta-se, assim, como estruturante do texto teatral escrito.

\section{- Estilo}

Outras perguntas indicadas na seção de estudo do texto dramático escrito buscam evocar características que remetem, também, à representação cênica. É o caso dos recursos gráficos que procuram marcar, sobretudo, aspectos da oralidade. Nessa direção, destacamos a proposta do capítulo de Português Linguagens (2009):

\footnotetext{
$\mathrm{Na}$ reprodução da fala das personagens, aparecem palavras escritas em negrito, palavras separadas em sílabas e palavras com repetições de vogais. Veja:

LÚCIO - É o meu, o meu trabalho, e não o seu que garante a segurança desta família.

SÍLVIA - E eu, se perco esta chance, eu vou ser na-da até o fim da vida, Lúcio! Na-da, a diferença é essa: na-da.

SÍLVIA - Pooooooooooooooor quê?

Imagine essa peça teatral sendo encenada em um palco. Como essas palavras seriam faladas pelas personagens?
}

Português Linguagens (2009, p.21, grifo dos autores)

A observação da proposta permite afirmar que a utilização de negrito pode imprimir uma entonação mais intensa, já a separação silábica permite dar ênfase em algumas palavras, da mesma forma, o alongamento de vogais pretende valorizá-las. Nesse sentido, entendemos que o exercício busca promover a relação entre as modalidades falada e escrita da língua.

Com relação ao emprego da pontuação (característica do texto escrito), as atividades encontradas nos livros didáticos analisados procuram fazer que o aluno observe, por exemplo, 
a relação entre o texto escrito e o texto oralizado/representado, como é o caso desta atividade do Projeto Eco (2009):

Na segunda cena, a presença de reticências é frequente.

- $\quad$ O que esse sinal está indicando?

- $\quad$ Sabendo que todo texto teatral é escrito para ser encenado em um palco, que relação existe entre as reticências e o contexto apresentado por esta cena?

Projeto Eco (2009, p.138)

Em relação à primeira pergunta, prevê-se que o uso das reticências revele pequena pausa, silêncio, tensão, reflexão, interrupção ou hesitação. No entanto, para respondê-la, o aluno precisa recuperar o segmento do texto dramático que se está considerando no exercício proposto:

PULQUÉRIA - A propósito, a comadre disse-me outro dia que tinha um segredo que contar-me... a respeito de...

MÔNICA - É verdade, e muito estimo que a comadre isso me lembre... Tenho passado um dia muito triste lembrando-me de minha mocidade, e estou certa que, contando esse segredo à comadre, hei de chorar e ficar mais aliviada...

Projeto Eco (2009, p.134)

No caso mencionado, o emprego das reticências marca o suspense que se quer imprimir no diálogo entre as personagens Pulquéria e Mônica. Essa afirmação responde à primeira pergunta do exercício proposto. Já a segunda pergunta busca correlacionar o emprego das reticências ao contexto da cena, a partir do pressuposto de que "todo texto teatral é escrito para ser encenado em um palco". Espera-se, assim, que o aluno atente para o fato de que as reticências também são direcionadas para os atores que tomarão o texto escrito como base para representação. $\mathrm{O}$ encaminhamento dado a essa atividade propõe dupla função das reticências: por um lado, indicam ao leitor o suspense necessário à cena e, por outro, apontam para o estado que os intérpretes das personagens devem assumir ao atuarem no diálogo dessa cena. 
De modo semelhante às reticências, os pontos de exclamação e interrogação também podem marcam a expressividade do texto dramático escrito, revelando a aproximação das modalidades escrita e oral. Em Para viver juntos (2008, p.139), pergunta-se a respeito do uso dos sinais de pontuação nesta fala: "Burro?! Então esse... que você chama de Nicolau é um burro? Um animal?!", e se quer saber, a partir disso, a respeito da personalidade do Padre. Esse recurso pode revelar ao leitor nuances sobre a personagem e pode indicar, também, ao ator, maneiras diversas de verbalizar essa fala.

A repetição de palavras também é evidenciada no estudo do texto dramático do capítulo de Diálogo Edição Renovada (2009, p.91), o qual apresenta um excerto retirado do texto de referência para discutir a respeito desse recurso: "Sim senhor. Então tá... vamos, vamos, sim senhor". Comumente utilizada na oralidade, conforme salientam estudiosos da Análise da Conversação (MARCUSCHI, 2002; KOCH, 2008), a repetição pode marcar, no texto dramático, por exemplo, a espontaneidade que se deseja imprimir no conjunto de falas e, aliada à pontuação, busca promover a inflexão necessária para expressar sentimentos das personagens, que os atores, por sua vez, terão de interpretar.

\section{- Propósito comunicativo}

Ainda a respeito das perguntas que compreendem a seção estudo do texto, localizamos nos livros didáticos sob análise alguns exemplos que preconizam a finalidade comunicativa do texto dramático, é o caso da atividade proposta em Português Linguagens (2009, p.22). Nesse capítulo, questiona-se: "Quando um texto teatral é lido, o leitor é o interlocutor da história vivida pelas personagens. Quando ele é encenado, quem é o interlocutor?". A pergunta busca instigar a reflexão a respeito do público-alvo da produção oral do gênero (plateia), ao compará-lo com o público-alvo do texto dramático escrito (leitor).

Depreendemos, assim, que o tratamento didático dispensado ao texto dramático nessa unidade didática prevê uma diferenciação nos planos de produção oral ou escrita do gênero, o que revela, consequentemente, uma seleção das esferas em que esse gênero pode circular: artística (quando é encenado) ou literária (quando é lido); esse dado parece apontar para a versão escolarizada do texto dramático. 
Enquanto a proposta anterior discute os interlocutores prováveis das situações apresentadas, o livro Português a Arte da Palavra (2009) considera, no próprio texto escrito, a (pré)-existência desse interlocutor, conforme destacamos, a seguir:

Na rubrica da última fala dessa cena está escrito "monólogo", e não há outra personagem prevista para dividir o palco com Petrúquio.

- A quem Petrúquio se dirige na última fala?

- Qual o objetivo desse monólogo?

Português a Arte da Palavra (2009, p.57)

Ao responder a estas perguntas, o aluno é levado a observar que o monólogo de Petrúquio é dividido com a plateia e que a personagem confidencia suas artimanhas para “domar" Catarina. A interação ator-público está prevista na produção escrita do texto dramático e promove um direcionamento próprio para a produção oral desse gênero. Em outras palavras, caso o texto seja apenas lido, o leitor terá acesso ao que a personagem tem a dizer, caso seja encenado, é à plateia que o ator dirigirá sua fala.

É válido mencionar, nessa direção, que os livros didáticos atribuem papel importante para o interlocutor final do texto dramático, por meio de textos expositivos que percorrem as unidades didáticas analisadas. As proposições, a seguir, ilustram tal asserção:

"Quando é levado à cena, o texto já não se relaciona com um leitor, mas com um espectador" - Português a Arte da Palavra, 2009, p.58

"O teatro só existe quando há esses três elementos: texto, ator e público" Linguagem Criação e Interação, 2010, p.87

“[...] é preciso lembrar que o texto teatral não é produzido para leitura. $\mathrm{O}$ dramaturgo [...], ao conceber uma ideia, imagina-a sobre um palco, sendo encenada para uma plateia" - Projeto Eco, 2009, p.146

"O teatro é uma obra de arte viva, um espetáculo que depende de quem atua e de quem assiste, ou seja, da interação entre plateia e elenco" - Diálogo Edição Renovada, 2009, p.94

Depreende-se, de forma explícita, no discurso desses livros didáticos, uma concepção de texto dramático arraigada a uma concepção de teatro. Outras atividades de leitura e 
compreensão que promovam a correlação entre texto dramático e representação cênica são exploradas de diferentes maneiras, conforme assinalamos nos exemplos a seguir.

Na proposta do livro Linguagem Criação e Interação (2010, p.92), há a definição de uma forma de teatro denominada teatro do absurdo, assim caracterizada pela unidade didática “(...) toda sorte de mudanças e liberdades em cena, dando a impressão de que o nonsense, o sem-sentido, reina sobre os homens e as coisas, num flagrante desrespeito a qualquer ordem, sistema ou noção de verossimilhança".

Depois dessa explicação, o aluno é levado a discutir sobre a intenção do autor (Jô Soares) ao escolher o título de seu texto "Teatro do absurdíssimo". A atividade orienta a que se promova a correlação entre os conteúdos oriundos do universo teatral às condições de produção (seleção do título) do texto dramático sob análise.

No capítulo do Projeto Eco (2009, p.145), há outros questionamentos: "No início do fragmento apresentado ['Auto da Compadecida'], vê-se a presença de um personagem que não volta a aparecer: um palhaço. Pode-se considerá-lo um narrador da história? Com que objetivo ele apareceu no texto?"

O aluno é, então, levado a observar a presença de uma personagem que tem a função de organizar o cenário para o início de cada cena, função essa, frequentemente assumida, em montagens teatrais, por contrarregras. Novamente, parte-se da relação entre informações constantes na produção escrita desse texto dramático e as funções assumidas na possibilidade de sua produção oral.

A discussão de outros elementos que compõem o universo da representação cênica é explorada nesta atividade do capítulo de Para viver juntos (2008):

[Um ou outro buzinar, foguetes estouram saudando Iansã, a Santa Bárbara nagô, e o sino da igreja começa a chamar para a missa das seis. Mas nada disso acorda Zé-do-Burro. Entra, pela ladeira, a Beata]. Nessas breves linhas, o dramaturgo indica os sons, a luz e o cenário necessários para esse quadro. Quando um texto dramático é lido, esses elementos são imaginados pelo leitor. Já quando o texto é representado, eles são efetivamente executados. Quem você supõe que os realiza?

Para viver juntos (2008, p.138) 
Nesse exercício, quer-se mostrar ao aluno a função de sonoplastas, iluminadores e cenógrafos que, junto a atores e atrizes, ajudam a compor a encenação. As indicações registradas no texto escrito podem auxiliar o leitor a imaginar situações apresentadas no decorrer da história e podem auxiliar, também, os técnicos envolvidos na representação cênica, os quais procuram viabilizar, durante o espetáculo, tais situações à plateia.

Destacamos, finalmente, que a maioria dos livros didáticos apresenta indicações de leitura de peças teatrais, obras teóricas sobre teatro ou filmes relacionados aos temas explorados no capítulo. Há, também, como conteúdo da esfera teatral, os primórdios da história do teatro e o significado das máscaras cênicas (tragédia e comédia).

Alguns elementos que compreendem o espaço da representação teatral, bem como a função que cada pessoa assume na montagem de uma peça teatral, são explorados nos livros didáticos que selecionamos. Destacamos duas delas, numeradas como 7 e 8 , que se apresentam na unidade didática de Português a Arte da Palavra (2009, p.60) e que são sugestivas de como a produção oral do texto dramático convoca a mobilização de um trabalho em equipe. 
Imagem 7 - Contexto de produção de um espetáculo teatral, Português a Arte da Palavra (2009, p.60)

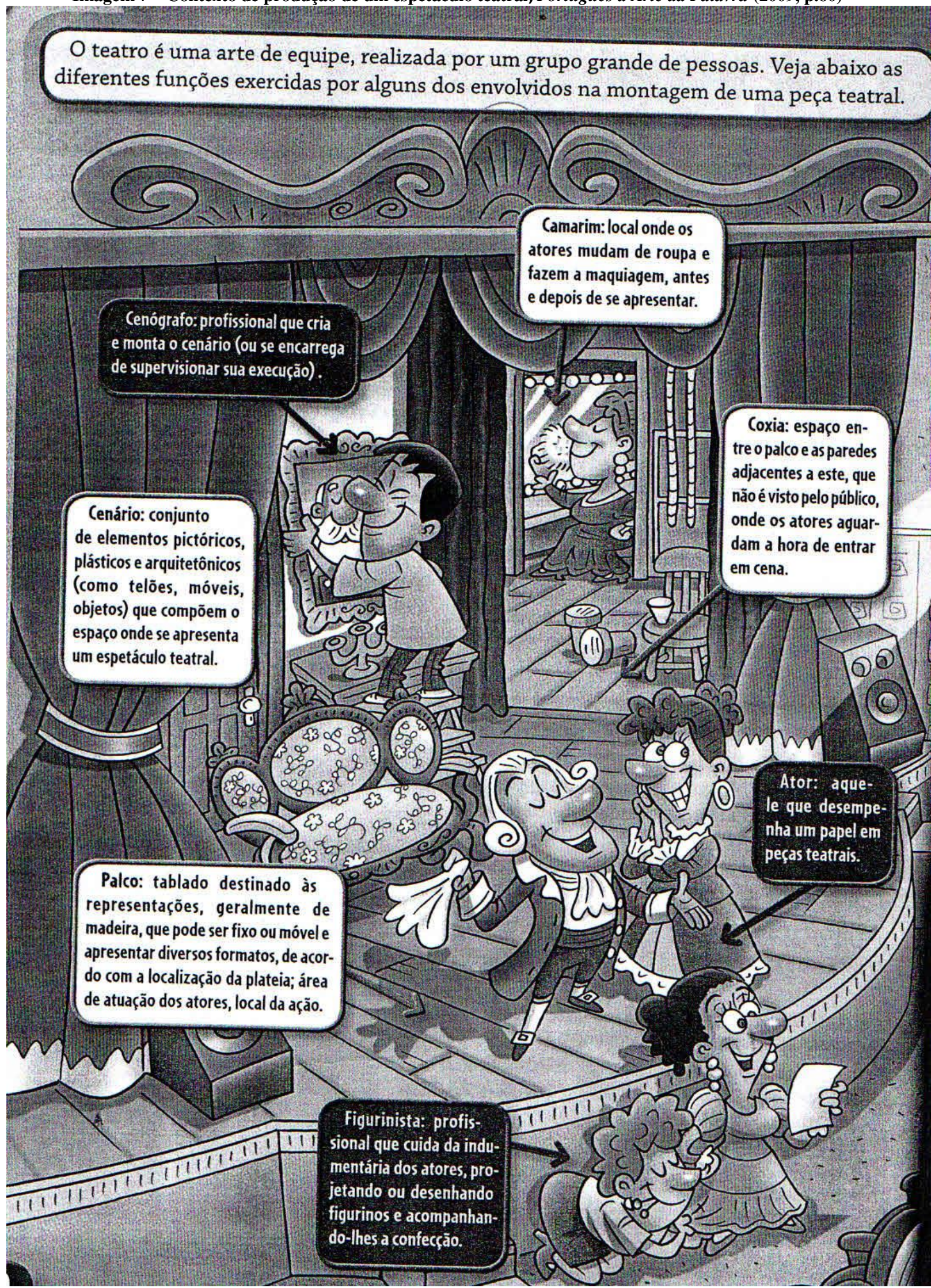


Imagem 8 - Contexto de produção de um espetáculo teatral, Português a Arte da Palavra (2009, p.61)

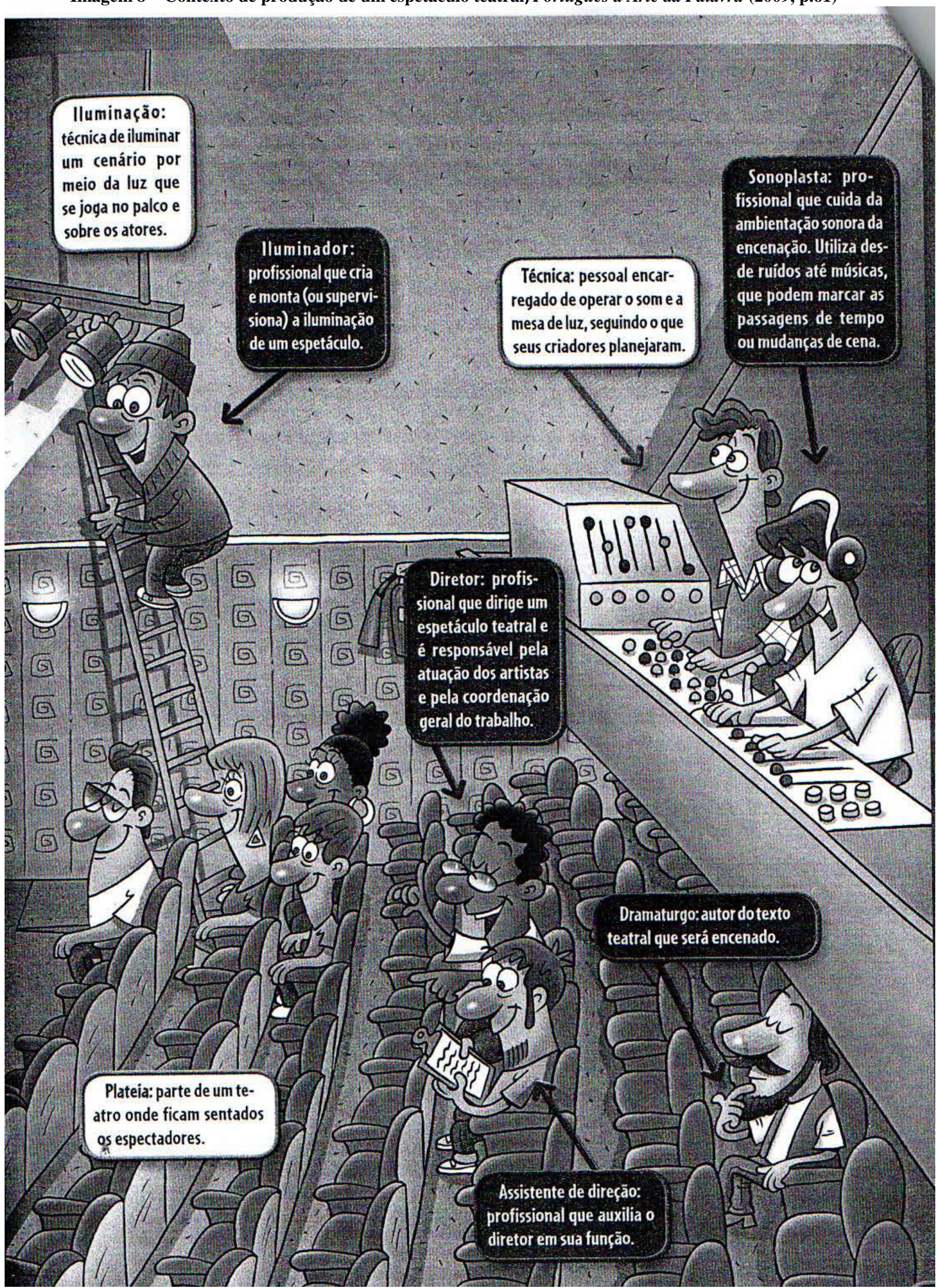


O discurso expositivo do livro didático, aliado à ilustração, pode ajudar a compor os saberes que englobam o universo das artes cênicas. Procedemos a essa afirmação a partir do que postulam Dolz, Noverraz e Schneuwly (2004, p.89), ao fato de se trabalhar com gêneros discursivos no ensino de língua, dado que os alunos aprendem a falar sobre o gênero, "adquirem um vocabulário, uma linguagem técnica, que será comum à classe e ao professor. [...] Eles constroem progressivamente conhecimentos sobre o gênero".

Em suma, as concepções que atravessam o discurso didático dos capítulos que se propõem a estudar o texto dramático, nas atividades de leitura e compreensão textual, ora direcionam o trabalho para um gênero pertencente à esfera literária, ora compreendem o texto como construto heterogêneo (diferenciando-o de outros textos da ordem do narrar), ora privilegiam a esfera teatral (ao ratificar a prática social que o engendra - representação cênica).

Na próxima seção, passamos a observar as atividades voltadas para a produção escrita e oral do texto dramático.

\subsubsection{Propostas de produção escrita e oral}

As atividades que envolvem a produção escrita do texto dramático nas unidades didáticas sob análise apresentam-se nas seguintes direções:

a) Criação de rubricas, esquemas e cenas.

b) Adaptação de textos narrativos em textos dramáticos.

Destacamos, primeiramente, as propostas que buscam ancorar a produção escrita do texto dramático e que configuram uma espécie de "aquecimento": criação de rubricas, criação de esquemas que possam estruturar a elaboração de uma peça teatral e criação de cenas, a partir de situações pré-estabelecidas ou da descrição de cenários. Na sequência, indicamos as 
propostas de produção do texto dramático, a partir da adaptação de outros gêneros, em sua maioria, narrativos.

a) Criação de rubricas, esquemas e cenas

Selecionamos uma proposta de produção textual da unidade didática de Linguagem Criação e Interação (2010) que prioriza o papel das rubricas no texto teatral:

A seguir, são apresentados alguns diálogos. Transcreva-os no caderno, criando rubricas adequadas às indicações de efeito que se pretende causar com cada um.

\section{Suspense}

Rita - Você escutou esse barulho?

Marcos - Escutei. O que será?

Rita - Não sei. Eu fechei todas as janelas.

Marcos - Vamos lá em cima verificar?

Rita - Não!! Pode ser alguém que tenha arrombado uma das janelas.

Marcos - Então, vamos chamar a polícia.

Rita - Vamos sim.

Linguagem Criação e Interação (2010, p.95)

A atividade propõe que o aluno exercite a indicação de rubricas no texto dramático escrito, que buscam, especificamente, causar o efeito de suspense. A mesma unidade didática apresenta, em seguida, a formulação de esquemas como exercício para o planejamento da escrita de uma cena teatral, conforme indicamos:

Fato: pai não consegue ler o jornal devido ao barulho produzido pelos filhos. Personagens: homem e quatro crianças - três meninas e um menino.

Cenário: interior de um apartamento.

Época: atual, domingo de manhã.

Linguagem Criação e Interação (2010, p.96) 
Entendemos que o esquema sugerido busca facilitar a escrita da cena, já que a indicação do mote e dos envolvidos, a definição de local e tempo podem auxiliar o aluno na organização do texto.

A fase do planejamento também é explorada na unidade didática de Para viver juntos (2008). A proposta é que o aluno escreva em grupo uma cena, com base em uma situação vivida por personagens estereotipadas. Algumas perguntas orientam essa produção: "Quais são os conflitos que surgem nesse tipo de convivência? Quem poderia provocar esses conflitos? Quem procuraria solucioná-los? Quem se intrometeria sem ser chamado?”. A atividade contempla a situação, o espaço, a linguagem e a caracterização de cada personagem.

Outras propostas solicitam a continuação de uma cena, considerando: alguns fatos contextuais específicos (PORTUGUÊS LINGUAGENS, 2009, p.23), a escrita de uma cena que antecederia aquela apresentada no capítulo (PARA VIVER JUNTOS, 2008, p.140) e a escrita de uma cena com base em provérbios, tal como os apresentados no texto utilizado como referência na unidade didática (TRAJETÓRIAS DA PALAVRA, 2009, p.239).

As orientações de produção escrita do texto dramático nas unidades didáticas analisadas correspondem a motivações variadas. A mais recorrente é a transformação de contos (ou outros gêneros) em textos dramáticos, conforme passamos a discutir.

\section{b) Adaptação de textos narrativos em textos dramáticos}

A atividade do capítulo de Diálogo Edição Renovada (2009) consiste, primeiramente, da produção de um conto de mistério e, em seguida, de sua adaptação em peça teatral. Para tanto, o livro apresenta um exemplo de um conto, "Um caso estranho", que foi convertido em texto dramático. Sugere-se que todos os alunos realizem esse processo e, ao finalizar a escrita do conto, leiam-na em voz alta para toda a turma. Depois da realização dessa etapa, é selecionado apenas um conto a ser adaptado para o teatro. As orientações para essa atividade solicitam a escrita de diálogos para cada cena, a indicação entre parênteses das ações, entonações, gestos e os momentos de entrada e saída de personagens. Após a escrita do texto dramático, o aluno é levado a avaliar sua produção para observar: se há alguma cena ou fala 
que possa ser omitida, se é necessário acrescentar algum diálogo para melhorar o desenvolvimento da história, se as rubricas indicam para o leitor o contexto da fala das personagens.

Em Linguagem Criação e Interação (2010), busca-se a criação de um texto que possa ser encenado. Para tanto, apresentam-se algumas crônicas e o propósito é transformá-las em textos teatrais. Primeiramente, solicita-se uma atividade de "aquecimento", com o acréscimo de elementos característicos do texto dramático, como rubricas e cenário, em uma microcrônica, já dialogada ("Pai não entende nada", de Luís Fernando Veríssimo). Em seguida, apresenta-se outra crônica, do mesmo autor ("Dona Nininha, coitada"), para a adaptação. As orientações apontadas para a produção do texto escrito retomam, em sua maioria, aspectos formais do texto, conforme podemos observar na proposta do livro didático sob análise:

- Em forma de rubricas, liste, no início do texto, os nomes das personagens.

- Descreva o cenário e as personagens com riqueza de detalhes.

- Suprima as partes do narrador.

- Especifique as ações e reações das personagens também por meio de rubricas.

- Indique o nome das personagens antes de suas respectivas falas.

- Aproveite o título da crônica ou crie um novo.

Linguagem Criação e Interação (2010, p.99)

A atividade proposta no capítulo do Projeto Eco (2009, p.147) sugere ser realizada em pequenos grupos; trata-se da criação de um texto dramático com base em uma notícia de jornal ("Procura-se uma rosa"). As orientações remetem às características do texto teatral escrito (rubricas, falas, pontuação, linguagem etc.) e preveem a troca de textos entre os colegas, além das sugestões do professor. Na retomada da produção coletiva, é solicitado ao grupo que reveja se os elementos necessários para encenação da peça foram contemplados na organização do texto escrito.

Em A aventura da linguagem (2009), a atividade de produção escrita consiste da adaptação de um conto de Machado de Assis em texto teatral, seguindo as instruções: 


\section{O grupo precisa decidir como indicar:}

- O tempo em que ocorre a história.

- As três épocas em que ela se desenvolve.

- A mudança de tempo [...].

- Os lugares em que ocorrem as cenas.

Não se esqueça de que todas estas indicações podem ser feitas por diversos recursos:

- Rubrica cênica.

- Roupas.

- Cenário.

- Modo de falar dos personagens.

- Diálogo [...].

Nos casos mencionados anteriormente, a produção do texto dramático escrito dá-se a partir da adaptação de um texto previamente apresentado; a ênfase maior está na indicação das rubricas e dos diálogos, recursos relacionados à estrutura composicional.

Em Trajetórias da palavra (2009, p.240), o comando solicita a leitura do texto "Amigo da onça" e, em seguida, apresenta algumas orientações, são elas: "O nome das personagens deve aparecer antes de sua fala, como na peça que você leu. Todas as passagens em que o narrador se manifesta devem ser suprimidas ou transformadas em rubricas [...]". Observamos que, ao indicar a adaptação de sequências textuais que recobrem a figura do narrador, esse exercício procura reforçar as diferenças entre texto teatral e texto narrativo, do ponto de vista estrutural, oferecendo instruções aos alunos, para que eles possam realizar a transposição escrita da história.

Diante do exposto, é possível afirmar que a maioria dos livros didáticos observados apresenta atividades de adaptação de um gênero que apresenta um predomínio de sequências narrativas, para outro que apresenta um predomínio de diálogos, como ocorre no gênero texto dramático. Verificamos que, nas orientações que acompanham as propostas de produção escrita do gênero, a ação dramática é raramente sinalizada, pois se preconiza, em grande medida, o leitor como público-alvo; trabalha-se a estrutura, sem relacioná-la, necessariamente, com a possibilidade de atender a outros interlocutores (ator, diretor, público) que o texto dramático pode convocar.

As atividades de produção de linguagem que focalizam a performance são apresentadas, de modo amplo, nas propostas de produção oral do texto dramático. As análises realizadas até o momento permitem-nos afirmar que os livros didáticos preveem, nas páginas 
de abertura e em algumas atividades de leitura e compreensão textual, a projeção do texto dramático escrito em um palco. Para dar continuidade a essa discussão, destacamos dois excertos expositivos que confirmam essa correlação:

"O texto dramático é escrito não só para ser lido, mas também - e principalmente - para ser representado" - Para viver juntos, 2008, p.137.

"Ainda que muitas vezes um texto teatral nunca seja encenado, seus autores o escrevem para esse fim. Por isso, ao lermos uma peça de teatro, devemos sempre ter em mente que ela foi escrita para ser levada ao palco" Português a Arte da Palavra, 2009, p.53.

As atividades dedicadas à produção oral do texto dramático centram-se, predominantemente, em práticas bastante específicas, oriundas da esfera teatral, as quais se destacam:

c) Improvisação.

d) Leitura dramática.

e) Encenação.

Essas práticas teatrais pressupõem o emprego de múltiplas semioses. Da hipótese de sua realização, entendemos que o aluno pode exercitar a oralidade (e as modulações aí implicadas) e outros meios de produção de linguagem que correspondem a: gestualidade, movimentos do corpo e dos olhos, expressões faciais etc.

c) Improvisação

O improviso teatral é encaminhado no material didático do modo como segue. $\mathrm{Na}$ proposta do livro Português a Arte da Palavra (2009), a primeira orientação dada ao aluno é a definição do conceito "improvisação", entendido como a interpretação de atores sem ensaio 
prévio ou memorização de falas. A partir disso, os alunos são convidados a representar situações, em grupo, por meio de mímica, levando em conta que "os gestos precisam ser bem visíveis e o mais preciso possível” ou realizar improvisações a partir da seleção de personagens com perfis diferentes, "uma moça tímida, um senhor rico, um menino travesso e sua mãe". Ao final do exercício, institui-se à plateia como avaliadora das apresentações. O resultado esperado é que os alunos se divirtam enquanto improvisam as situações, e àqueles que assistiram tenham identificado as situações improvisadas. Essa atividade parece promover a interação entre atores e plateia.

\section{d) Leitura dramática}

Na leitura dramática, estabelece-se uma oralização do texto dramático escrito, ou seja, este é utilizado como apoio para produção oral, conforme assinala Ryngaert (1995). O livro Diálogo Edição Renovada (2009, p.85) apresenta a definição de leitura dramática como tipo de "leitura interpretada (por atores, diretor ou apenas um ator diante do público) de uma peça teatral. Na leitura, as emoções são passadas pela voz, exigindo dos atores as inflexões vocais necessárias à composição do personagem". O livro didático apresenta, nas páginas seguintes, a atividade:

Observem as pausas, indicadas pelos sinais de pontuação. A leitura e a projeção da voz dependem da respiração adequada.

Articulem bem as vogais e as consoantes das palavras; $\mathbf{r}$ e $\mathbf{s}$, no final das palavras (sorrir, férias), devem ser bem pronunciados; tenham o mesmo cuidado com os encontros consonantais (pedra).

Diálogo Edição Renovada (2009, p.94, grifo dos autores)

No exemplo mencionado, a dicção exigida é detalhada no comando da atividade; o aluno deve atentar, por exemplo, à pronúncia/articulação de determinadas letras. $\mathrm{O}$ respeito à pontuação também aparece como instrução para inflexão da voz e a respiração se mantém relacionada à sua projeção. 
Nessa direção, destacamos, também, a atividade do capítulo de Português a Arte da Palavra (2009) que compreende a entonação como recurso essencial para construção das personagens que os alunos são motivados a interpretar:

Procurem dar à voz a firmeza que o diálogo exige. O tom de voz pode revelar o temperamento das personagens.

Caprichem na entonação. Carreguem na expressão do texto.

Ajudem com expressões faciais, gestos e movimentação corporal. Respirem fundo e se concentrem.

Português a Arte da Palavra (2009, p.57)

Ao realizar a leitura dramática, o aluno é convidado a observar que o texto teatral exige um desempenho oral diferente, o que para nós significa multimodal, pois a leitura aqui se faz de forma concentrada, com expressividade da voz, da face e do corpo todo.

Em Português Linguagens (2009), as orientações recorrem a comparações e ilustrações que procuram facilitar o entendimento do "como" o aluno deve ler as falas de cada personagem:

[...] Não deixem cair a entonação no final de frases. Observem como falam os locutores de rádio e televisão e procurem imitá-los. [...] Para ajudar no volume da voz, imaginem - como fazem no meio teatral - que na última fileira do teatro há uma velhinha meio surda e que vocês devem representar para ela.

Português Linguagens (2009, p.37)

Essas orientações encaminham a que o aluno possa trabalhar com a dicção das palavras e das frases. A ilustração da velhinha surda, por exemplo, é uma técnica recorrente no universo das artes cênicas, que procura aprimorar a percepção (a consciência) do volume que se deve empregar em uma apresentação teatral - seja leitura dramática ou representação cênica (STANISLAVSKI, 2001[1936]).

No capítulo de Trajetórias da palavra (2009, p.232), o aluno é levado a se expressar, de forma a empregar emoções e sentimentos vivenciados pelas personagens. Neste exemplo, um dado significativo é a escolha de um aluno para realizar a leitura das rubricas, conforme 
destacamos: "O professor escolherá os alunos que farão a leitura oral do trecho de 'O bemamado’ reproduzido no início deste capítulo - um de vocês lerá as rubricas (trechos em itálico) e os demais lerão as falas das personagens". A seleção de um aluno designado para leitura das rubricas parece constituir efeito da escolarização do texto dramático, já que essa tarefa não é comumente empregada na montagem e/ou apresentação de uma peça teatral de uma trupe amadora e/ou profissional (TORO, 1989). A leitura das rubricas reflete uma tarefa essencialmente escolar, necessária para a produção oral/escrita desse gênero discursivo. Em outras palavras, é solicitado aos alunos que leiam em voz alta as rubricas do texto dramático, para que possam se familiarizar com as operações de escrita específicas de um texto como esse e para que consigam realizar suas próprias marcações na escrita, a fim de que se orientem para a expressividade que será exigida, posteriormente, na fala.

A leitura das rubricas também é sugerida no capítulo de A aventura da linguagem (2009). Na orientação de como proceder à leitura dramática, há a solicitação de que o aluno imprima à sua leitura o modo de ser de cada personagem, pronuncie as palavras em tom alto e claro, mas com naturalidade, e seja bastante expressivo. Já o participante responsável pela leitura das rubricas, deve fazê-las em tom grave e em off, isto é, fora das vistas do público. A demarcação no texto escrito - emprego dos parênteses ou o uso do itálico - é deslocada para a produção do texto oral (inclusive espacialmente), de forma a diferenciar, na encenação, a fala, o(s) modo(s) de falar e de permanecer ou não visível à cena.

Em Para viver juntos (2008), as orientações para a leitura dramática do texto promovem a interação entre os colegas de classe, posto que dois alunos são convidados a trocar experiências no processo de leitura de uma cena criada por eles, conforme indica o passo a passo da atividade: 
- Leia a cena em voz alta com o seu colega, cada um representando um papel.

- Leia-a novamente, mas trocando de papel com ele.

- A interpretação que o seu colega deu ao seu papel ensinou a você algo a respeito das possibilidades de sua personagem? Como você pode aperfeiçoar o volume, o tom, as inflexões de voz para transmitir suas emoções do melhor modo para o ouvinte? De que maneira as pausas, olhares e gestos podem também contribuir?

- Leia uma terceira vez o texto em voz alta, retomando o seu papel original e dando-lhe vida com base no estudo que você realizou.

- Em data previamente combinada com o(a) professor(a), leia diante da classe a cena criada.

Para viver juntos (2008, p.141)

Essa atividade é desenvolvida em duplas e o texto sugerido para leitura é aquele realizado no momento da produção escrita. Há engajamento e direcionamento nas duas etapas de produção: o aluno escreve um texto dramático, para depois lê-lo com o colega para toda turma. Conforme solicita o comando, a leitura dramática vai sendo aperfeiçoada no decorrer da própria leitura e na observação das possibilidades de entonação (e performances) que o colega consegue empregar.

$\mathrm{Na}$ sequência, apresentamos as propostas de produção oral do texto dramático, caracterizadas por atividades que buscam a dramatização do texto de referência, estudado na unidade didática, ou do texto produzido pelos alunos.

\section{e) Encenação}

A encenação é colocada, em geral, como proposta de fechamento do trabalho realizado com o texto dramático. As propostas encontradas nos livros didáticos sob análise buscam orientar a montagem do espetáculo e oferecem ao aluno instruções gerais sobre esse processo. É o caso da atividade do capítulo de Português Linguagens (2009): 
- Façam a leitura dramática do texto teatral. [...]

- Cada um decora as falas de sua personagem, imaginando as situações vividas por ela, o cenário e as outras personagens com quem ela se relaciona.

- Além das rubricas de interpretação, observem também as de movimento.

- Criem o cenário, a sonoplastia [...], os figurinos. Para isso, contem com a criatividade de todos.

- Ensaiem quantas vezes forem necessárias.

- Para ajudar, caso alguém se esqueça de uma parte do texto durante os ensaios ou na apresentação, recorram ao ponto. Ponto é uma pessoa que vai lendo o que os atores devem dizer, para lhes ajudar a memória.

- Tudo pronto, montem o espetáculo e preparem a apresentação.

- Durante os ensaios e as apresentações, coloquem-se naturalmente no lugar das personagens e vivam-nas, ou seja, comecem a fazer teatro.

- Caso gostem muito dessa atividade, formem um grupo de teatro com seus colegas e, seguindo as mesmas orientações, encenem outros textos e, quem sabe, uma peça de teatro completa.

Português Linguagens (2009, p.69, grifo dos autores)

A atividade apresenta orientações que dizem respeito ao "como" proceder no processo da montagem de uma peça teatral: decorar falas, criar cenário, sonoplastia e figurinos, ensaiar, preparar a apresentação, recorrer ao ponto, agir naturalmente, enfim, "começar a fazer teatro". O encaminhamento pauta-se na criatividade e no engajamento dos alunos em cada uma das etapas destacadas.

Caso semelhante a esse ocorre na atividade de encenação, proposta pela unidade didática de A aventura da linguagem (2009, p.111), cujo incentivo manifesta-se da seguinte forma: "Vá em frente! Estimule seus colegas, peça ajuda ao(à) professor(a) e montem uma das peças. A representação pode ser no auditório da escola ou na quadra. Ou, quem sabe, em um teatro de sua cidade!".

Os capítulos dos livros Projeto Eco (2009, p.148-149) e Português a Arte da Palavra (2009, p.78-79) também direcionam as tarefas que devem ser cumpridas para a montagem de uma peça teatral. Em ambos os casos, as instruções são numeradas sequencialmente e os alunos são conduzidos à realização das seguintes etapas: escolha do texto, leitura, distribuição dos papéis, ensaios, produção do cenário, da sonoplastia, dos figurinos, divulgação da peça e apresentação propriamente dita.

Buscamos outro exemplo que contempla, além da organização de elenco, cenário, figurino, sonoplastia e iluminação, o papel do diretor e a função que lhe é atribuída, conforme assinalam as orientações do capítulo de Linguagem Criação e Interação (2010): 
- Determinem quem serão os atores, quem preparará o cenário e quem se encarregará do figurino.

- Caso julguem necessário, escolham alguém que cumpra a função de diretor (aquele que distribui os papéis e orienta os atores nas marcações, ou seja, define os movimentos, as posições e as atitudes dos atores na cena).

- Estudem e decorem o texto.

- Realizem ensaios coletivos para verem as marcações.

- Determinem as pessoas que serão responsáveis pela sonoplastia e pela iluminação.

- Vocês podem ainda trocar ideias com alguém que já tenha trabalhado ou atuado em uma peça teatral.

Linguagem Criação e Interação (2010, p.108)

Uma das sugestões na atividade descrita consiste da conversa com algum profissional das artes cênicas, uma vez que os saberes mobilizados nesse exercício podem ser apreendidos, também, por meio de técnicas teatrais.

Em Trajetórias da palavra (2009), apresenta-se o passo a passo para a realização de uma mostra de teatro. A análise das tarefas sugeridas permite dizer que se focaliza, sobretudo, a dimensão performática do gênero, isto é, o fato de que o texto dramático representado evoca a dinâmica de trocas verbais articuladas às expressões corporais, aos movimentos dos olhos, aos gestos, como se observa a seguir:

- Fazer alguns ensaios antes da apresentação definitiva.

- Observar o posicionamento dos atores no palco - ninguém deve ficar de costas para o público, a menos que a cena exija.

- Pronunciar as falas com clareza e altura de voz suficiente para que todos possam ouvi-las.

- Se possível, usar cenário, figurino e trilha sonora adequada à situação imaginada.

- Pedir a um colega que se encarregue de controlar a luz e a música durante a apresentação.

- Durante a apresentação, o público deve ficar em silêncio, para não desconcentrar os atores (no teatro, o terceiro sinal sonoro antes da entrada dos atores no palco indica que todos devem fazer silêncio para que a peça tenha início). [...]

Trajetórias da palavra (2009, p.241)

$\mathrm{Na}$ atividade proposta por esse livro didático, as recomendações são mais específicas, como o fato de que o ator não deve ficar de costas para o público e de que ele deve falar alto e 
com clareza. Há informação do que se deve esperar do comportamento da plateia e, para tanto, é inserido um conteúdo pertencente ao universo teatral: os três sinais sonoros.

A seguir, buscamos apresentar um cômputo geral das análises efetuadas ao longo deste capítulo.

\subsection{Resultados das análises}

Quanto ao discurso do ensino, apreendidos das análises dos livros didáticos, a escolarização do gênero acompanhou, em primeira instância, a condição literária do texto dramático, que parece retomar contribuições dos autores da teoria da literatura clássica (PLATÃO, 1997; ARISTÓTELES, 2005). Nessa direção, as propostas de atividades parecem seguir a orientação dos PCN (BRASIL, 1998), quanto ao agrupamento do gênero texto dramático na ordem do narrar. Observamos, no entanto, ao longo das unidades didáticas analisadas, que a concepção do texto dramático é constantemente construída e reconstruída pelo discurso da esfera artística/teatral.

A descrição das categorias nomeadas para análise das oito (08) unidades didáticas permite-nos indicar algumas asserções que apontam para a versão escolar do texto dramático:

I. O cânone literário é vastamente utilizado como gênero de referência para leitura e atividades de compreensão textual; a incidência maior dá-se com fragmentos.

II. A esfera literária é preferida para dar suporte às atividades de leitura e produção do texto escrito.

III. A esfera teatral é privilegiada para presentificação do objeto de ensino (abertura do capítulo) e para as atividades de produção oral.

IV. A concepção de texto dramático oscila entre texto narrativo, texto narrativo com estrutura diferente, texto para encenar. 
V. O público-alvo do texto dramático acompanha a concepção do gênero.

O Quadro 4, a seguir, busca sintetizar os resultados obtidos com a descrição e análise das categorias selecionadas para esta etapa da pesquisa: 
Quadro 4 - Categorias de análise para análise dos livros didáticos e resultados

\begin{tabular}{|c|c|c|}
\hline Categorias de análise & Itens observados & Resultados \\
\hline \multirow[t]{4}{*}{ 1) Abertura do capítulo } & \multicolumn{2}{|c|}{ Finalidades das propostas para presentificação do objeto de ensino } \\
\hline & $\begin{array}{l}\text { a) Ativação do conhecimento prévio a respeito do objeto } \\
\text { de ensino }\end{array}$ & Ênfase dada à esfera artística/teatral. \\
\hline & $\begin{array}{l}\text { b) Proposição de atividades em torno do objeto de } \\
\text { ensino }\end{array}$ & $\begin{array}{l}\text { Experimentação de outras semioses (ações e gestos), por } \\
\text { meio de jogos teatrais. }\end{array}$ \\
\hline & c) Definição e topicalização do objeto de ensino & $\begin{array}{l}\text { Dualidade na definição de texto dramático (texto para ser lido } \\
\text { ou encenado). }\end{array}$ \\
\hline \multirow{4}{*}{$\begin{array}{l}\text { 2) Atividades de leitura e } \\
\text { compreensão de textos }\end{array}$} & \multicolumn{2}{|c|}{ Concepções de texto dramático que evocam da análise das perguntas alocadas na seção estudo do texto } \\
\hline & $\begin{array}{l}\text { a) O texto dramático escrito é um texto narrativo e } \\
\text { pertence à esfera literária }\end{array}$ & $\begin{array}{l}\text { Foco nos elementos da narrativa: tempo, espaço, enredo, } \\
\text { personagens. }\end{array}$ \\
\hline & $\begin{array}{l}\text { b) Ainda que o texto dramático seja um texto narrativo, } \\
\text { ele apresenta uma estrutura composicional diferenciada } \\
\text { dos outros textos narrativos }\end{array}$ & $\begin{array}{l}\text { Estrutura do texto dramático escrito compara-se à estrutura } \\
\text { do texto narrativo: habitual ausência de narrador, presença de } \\
\text { diálogos e rubricas. }\end{array}$ \\
\hline & c) O texto dramático escrito convoca a uma encenação & $\begin{array}{l}\text { Direcionamento do texto para outros interlocutores (atores, } \\
\text { diretor, público). } \\
\text { Dupla função de recursos da linguagem: rubricas, cenas, } \\
\text { recursos gráficos, alongamento de vogais, pontuação e } \\
\text { repetição. }\end{array}$ \\
\hline \multirow{6}{*}{$\begin{array}{l}\text { 3) Propostas de produção } \\
\text { escrita e oral }\end{array}$} & \multicolumn{2}{|c|}{ Atividades para produção escrita e oral do texto dramático } \\
\hline & a) Criação de rubricas, esquemas e cenas & Foco para estrutura composicional. \\
\hline & b) Adaptação de textos narrativos em textos dramáticos & Foco para estrutura composicional. \\
\hline & c) Improvisação & $\begin{array}{l}\text { Espaço para inter-relação entre fala e ação. Sem apoio do } \\
\text { texto escrito. }\end{array}$ \\
\hline & d) Leitura dramática & $\begin{array}{l}\text { Ênfase na modalidade oral e suas particularidades: pronúncia, } \\
\text { modulação, ritmo, dicção, volume, entonação etc. Apoio do } \\
\text { texto escrito. }\end{array}$ \\
\hline & e) Encenação & $\begin{array}{l}\text { Abordagem dos envolvidos em uma montagem teatral: } \\
\text { cenário, figurino, sonoplastia, iluminação, direção e outros. } \\
\text { Apoio do texto escrito no momento de memorização das } \\
\text { falas, depois sem texto (instituição da figura do Ponto). }\end{array}$ \\
\hline
\end{tabular}


Acreditamos que os livros didáticos analisados apresentam propostas diversificadas para o ensino do texto dramático e podem auxiliar o trabalho do professor em sala. Não há como afirmarmos quanto aos resultados da aplicação desse conjunto de atividades, pois se configuram, apenas, representações do ensino de língua portuguesa; não se trata, portanto, do ensino efetivo.

Assim, com o intuito de aproximar nossa investigação às práticas escolares, recorremos à observação de questionários, que têm por temática o ensino e a aprendizagem do texto dramático e que foram aplicados a professores de língua portuguesa e alunos, os quais se constituem objeto de descrição e análise do capítulo IV. 


\section{CAPÍTULO IV}

\section{O texto dramático sob o olhar de professores de língua portuguesa e de alunos}

Sou um pouco ator, como todo professor deve ser. Ariano Suassuna

Neste capítulo, buscamos explicitar a percepção de professores e alunos de língua portuguesa a respeito do ensino do texto dramático. Para tanto, formulamos questionários ${ }^{36}$ específicos - o modelo encontra-se nos Anexos I e II deste trabalho. O conjunto de dados que apresentamos compõe-se de um questionário aplicado a noventa e nove (99) professores da rede pública de ensino, que lecionam língua portuguesa em municípios localizados no norte do Paraná, e um questionário aplicado a cento e setenta e sete (177) alunos de $8^{\text {os }}$ e $9^{\text {os }}$ anos de uma escola pública de Maringá.

Destacamos o fato de que esse conjunto de dados soma-se aos dados dos livros didáticos selecionados para esta pesquisa, discutidos no capítulo III, e recobre, uma vez mais, nosso interesse em descrever e problematizar a versão escolar do texto dramático. Na primeira seção deste capítulo, apresentamos as condições de produção que sustentam a elaboração e a aplicação dos questionários supracitados.

\footnotetext{
${ }^{36}$ A seleção de questionários como técnica de geração de dados segue as orientações metodológicas de Lüdke e André (1986).
} 


\subsection{Condições de produção dos questionários}

O questionário que elaboramos para professores de língua portuguesa encontra-se no final desta pesquisa, e corresponde ao Anexo I. Contém treze (13) perguntas, em sua maioria objetivas ou de múltipla escolha, em que se solicita assinalar com um "X" a opção que se julgar mais adequada; outras questões exigem, ainda, uma complementação à resposta dada. As perguntas buscam conhecer quais são os eixos de ensino privilegiados nas aulas do professor e o tipo de trabalho realizado com textos, além disso, questiona-se quais são os gêneros tipicamente utilizados da ordem do narrar e quais exploram a oralidade; no final do questionário são inseridas perguntas referentes aos conteúdos próprios do teatro e, mais especificamente, do texto dramático.

Para os alunos, elaboramos um questionário (Cf. Anexo II) com sete (07) perguntas em que se solicita assinalar "sim" ou "não" e, em caso afirmativo, complementar a resposta. As questões objetivam saber se o aluno já assistiu a uma peça fora/dentro da escola, se já fez parte de algum teatro na escola, em qual disciplina, se observou peças teatrais no livro didático e se já leu/escreveu alguma peça.

Importa mencionar que, nos questionários propostos, não indicamos campos específicos para complementação de dados pessoais e profissionais, tais como nome, idade, sexo, formação acadêmica e tempo de serviço, já que não constitui interesse desta pesquisa a correlação entre informações desta ordem e respostas dadas pelos professores de língua portuguesa e pelos alunos. Procedemos, então, à identificação dos questionários a partir da utilização da sigla QP (Questionário para Professores) ou QA (Questionário para Alunos), localizada na parte superior da folha, acrescida de um número correspondente, por exemplo, QP: 001 ou QA: 001.

Depois de elaborado o material, encaminhamos a proposta de pesquisa para aprovação do órgão de educação competente - coordenação da área de Língua Portuguesa, do Núcleo Regional de Educação de Maringá (NRE-Maringá) - responsável por cento e quatro (104) escolas da rede pública de ensino, distribuídas em vinte e cinco (25) municípios, localizados no norte do Estado do Paraná, conforme podemos verificar no mapa (Imagem 9): 


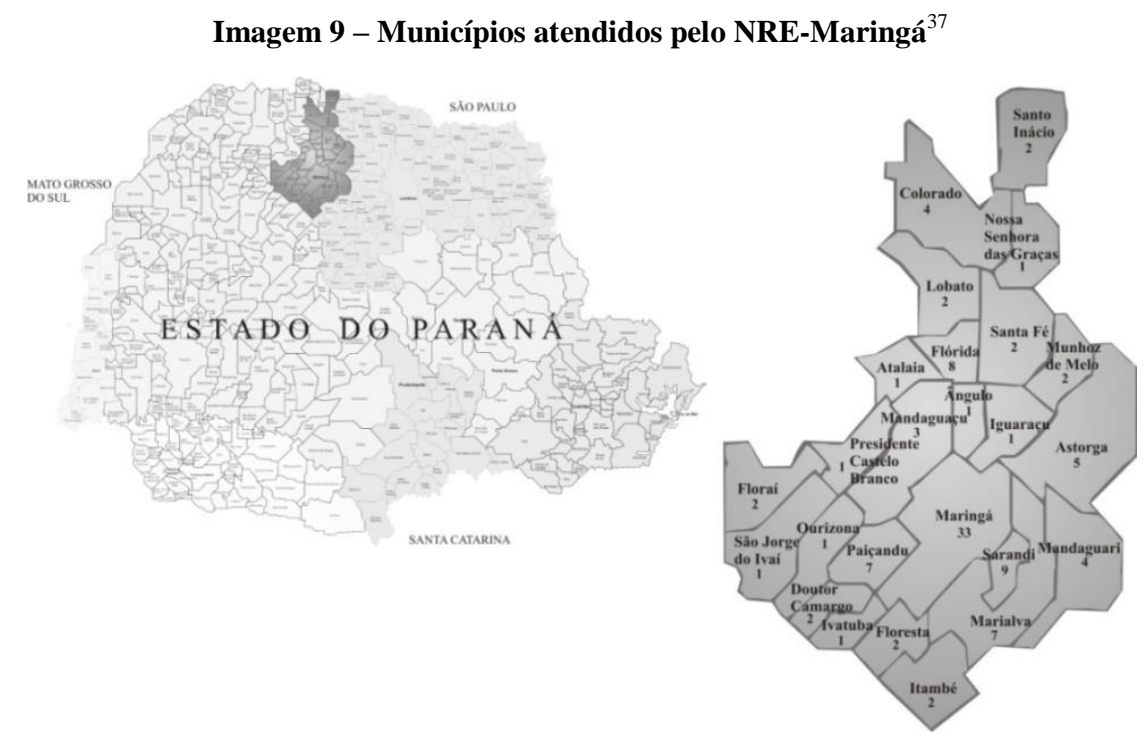

A etapa seguinte correspondeu à aplicação do questionário para professores no período de maio a junho de 2012. Todas as escolas estaduais localizadas nos municípios atendidos pelo NRE-Maringá, cento e quatro (104), receberam dois (02) questionários, endereçados aos professores de língua portuguesa que atuavam, naquele ano, necessariamente, no $8^{\circ}$ e/ou $9^{\circ}$ ano do ensino fundamental. Além das questões, foi enviada uma carta de apresentação ${ }^{38}$ à direção da escola, a fim de explicitar os objetivos da pesquisa e solicitar a participação voluntária dos professores daquela instituição. Esclarecemos que os questionários destinados aos professores foram respondidos sem a nossa intervenção.

No final do prazo estabelecido para devolução dos questionários, a pesquisa contou com a participação de noventa e nove (99) professores, distribuídos em quarenta e sete (47) instituições - localizadas em dezenove (19) municípios. No Quadro 5, a seguir, apresentamos as escolas contempladas nesta etapa da pesquisa e seus respectivos municípios.

\footnotetext{
${ }^{37}$ Informação disponível no site: www.nre.seed.pr.gov.br/maringa.

${ }^{38}$ Cf. Anexo III.
} 
Quadro 5 - Abrangência da aplicação dos questionários aos professores de língua portuguesa

\begin{tabular}{|c|c|c|}
\hline 1. & Centro Estadual de Educação Básica para Jovens e Adultos & Colorado \\
\hline 2. & Centro Estadual de Educação Básica para Jovens e Adultos & Mandaguari \\
\hline 3. & Centro Estadual de Educação Básica para Jovens e Adultos & Sarandi \\
\hline 4. & Colégio Estadual Alberto Jackson Byington Júnior & Maringá \\
\hline 5. & Colégio Estadual Basílio Pertsew & Ângulo \\
\hline 6. & Colégio Estadual Brasílio Itiberê & Maringá \\
\hline 7. & Colégio Estadual Cora Coralina & Maringá \\
\hline 8. & Colégio Estadual Dirce de Aguiar Maia & Maringá \\
\hline 9. & Colégio Estadual Dr. Felipe Silveira Bittencourt & Marialva \\
\hline 10. & Colégio Estadual Dr. Gastão Vidigal & Maringá \\
\hline 11. & Colégio Estadual Egídio Ballarotti & Astorga \\
\hline 12. & Colégio Estadual Engenheiro José Faria Saldanha & Munhoz de Mello \\
\hline 13. & Colégio Estadual Governador Adolpho de Oliveira Franco & Astorga \\
\hline 14. & Colégio Estadual Jardim Independência & Sarandi \\
\hline 15. & Colégio Estadual Jardim Panorama & Sarandi \\
\hline 16. & Colégio Estadual João de Faria Pioli & Maringá \\
\hline 17. & Colégio Estadual Juracy Rachel Saldanha Rocha & Marialva \\
\hline 18. & Colégio Estadual Márcia Vaz Tostes de Abreu & São Jorge do Ivaí \\
\hline 19. & Colégio Estadual Monteiro Lobato & Colorado \\
\hline 20. & Colégio Estadual Nilson Batista Ribas & Marialva \\
\hline 21. & Colégio Estadual Olavo Bilac & Sarandi \\
\hline 22. & Colégio Estadual Pedro Viriato Parigot de Souza & Marialva \\
\hline 23. & Colégio Estadual Rodrigues Alves & Maringá \\
\hline 24. & Colégio Estadual Rui Barbosa & Iguatemi \\
\hline 25. & Colégio Estadual Santa Maria Goretti & Maringá \\
\hline 26. & Colégio Estadual Serafim França & Astorga \\
\hline 27. & Colégio Estadual São Francisco de Assis & Ivatuba \\
\hline 28. & Colégio Estadual Tânia Varella Ferreira & Maringá \\
\hline 29. & Colégio Estadual Tereza Cristina & Colorado \\
\hline 30. & Colégio Estadual Tomaz Edson de Andrade Vieira & Maringá \\
\hline 31. & Colégio Estadual Umberto de Campos & Atalaia \\
\hline 32. & Colégio Estadual Unidade Polo & Maringá \\
\hline 33. & Colégio Estadual Vera Cruz & Mandaguari \\
\hline 34. & Colégio Estadual Vital Brasil & Maringá \\
\hline 35. & Escola Estadual Antônio Francisco Lisboa & Sarandi \\
\hline 36. & Escola Estadual Benedito Romualdo de Souza & Cambuí \\
\hline 37. & Escola Estadual Cecília Meireles & Santa Fé \\
\hline 38. & Escola Estadual Cecília Meireles & Colorado \\
\hline 39. & Escola Estadual Francisco José Perioto & Mandaguaçu \\
\hline 40. & Escola Estadual José de Anchieta & Paiçandu \\
\hline 41. & Escola Estadual Marco Antônio Pimenta & Maringá \\
\hline 42. & Escola Estadual Princesa Izabel & Paiçandu \\
\hline 43. & Escola Estadual Presidente Arthur da Costa e Silva & Floresta \\
\hline 44. & Escola Estadual Prof. Giampero Monacci & Itambé \\
\hline 45. & Escola Estadual Regente Feijó & Doutor Camargo \\
\hline 46. & Escola Estadual São Vicente Palotti & Mandaguari \\
\hline 47. & Escola Estadual Veríssimo de Souza & Astorga \\
\hline
\end{tabular}


Reiteramos que as quarenta e sete (47) escolas anteriormente mencionadas receberam, cada uma, dois (02) questionários; isto resultaria na participação máxima de noventa e quatro (94) professores. A participação real de noventa e nove (99) professores deve-se ao fato de que algumas escolas realizaram cópias do material de aplicação, para que mais professores pudessem respondê-lo; nesses casos, o número de identificação do questionário (QP: 001, por exemplo) apareceu duplicado ou triplicado.

Quanto ao questionário destinado aos alunos, selecionamos o mês de maio de 2013 para sua aplicação. A assessoria de Língua Portuguesa do NRE-Maringá direcionou a escolha da instituição pública que participaria desta etapa da pesquisa e, também, da etapa seguinte aplicação de uma sequência didática em torno do texto dramático a uma turma de $8^{\circ}$ ou $9^{\circ}$ ano do ensino fundamental, assunto de que tratamos no capítulo $\mathrm{V}$ deste trabalho. Foi sugerido o Colégio Estadual Rodrigues Alves, acompanhado do argumento de que tal escola acolheria um projeto que propiciasse o engajamento dos alunos, principalmente, nas aulas de Português.

Para a coleta de informações a respeito dessa instituição, procedemos a uma entrevista com a coordenadora pedagógica do ensino fundamental, a qual nos relatou o fato de o Colégio Estadual Rodrigues Alves ser uma das instituições públicas mais antigas da cidade de Maringá, que contém, inclusive, a mesma idade do município, sessenta e seis (66) anos; é, também, uma das maiores escolas da cidade, atendendo, em média, mil e cem (1.100) alunos nos turnos da manhã, tarde e noite. Segundo a coordenadora pedagógica, o Colégio atende alunos de classes mais populares, caracterizando-o, assim, como uma instituição de periferia.

A anuência por parte da direção e coordenação do Colégio Estadual Rodrigues Alves quanto à aplicação das duas etapas da pesquisa (aplicação de questionários aos alunos de $8^{\text {os }} \mathrm{e}$ $9^{\text {os }}$ anos da referida instituição e de uma sequência didática a uma das turmas) deu-se em razão das dificuldades apresentadas pelos alunos nas atividades de leitura e de interpretação de textos. Transcrevemos, a seguir, um depoimento da coordenadora pedagógica que evidencia a relevância do desenvolvimento de pesquisa no contexto escolar público:

[...] a escola pública ela tem assim::.... um código que não é escrito entendeu?... a escola sabe... ela tem uma vida que não tá escrita em papel nenhum $n e ́ ? . .$. ela tem uma diNÂmica... ela não tá em nenhum projeto pedagógico... não esTÁ... se você ler esse aqui óh ((aponta para a cópia do projeto pedagógico da escola)) você não vai encontrar nada do que eu to falando... mas se você ficar aqui uma semana você vai ver como que ela tem... 
é um verdadeiro laboratório... não existe... não existe melhor laboratório do que você frequentar uma escola pública... e sobretudo de periferia... entendeu? porque daí/aí o que que você vê... o que dá certo... o que não dá certo... $[. . .]^{39}$.

Com o consentimento da direção e coordenação da escola, conduzimos a aplicação (presencial) dos questionários às turmas de $8^{\text {os }}$ e $9^{\text {os }}$ anos do Colégio Estadual Rodrigues Alves. Nessa instituição havia cinco (05) turmas de cada uma dessas séries, distribuídas nos turnos da manhã e da tarde; ao todo, cento e setenta e sete (177) alunos responderam ao questionário. No momento da aplicação, os procedimentos foram:

- Apresentação da pesquisa e da universidade na qual se filia.

- Convite à participação voluntária dos alunos.

- Explicação do formato do questionário e indicações de como respondê-lo (não identificar-se, completar a série correspondente, escrever à caneta e responder às questões individualmente).

- Indicação de como proceder em caso de dúvidas.

- Indicação de como proceder quando terminar de responder o questionário.

- Agradecimento ao professor da turma pelo tempo concedido e aos alunos pela participação.

As próximas seções têm por objetivo apresentar os resultados obtidos com a aplicação dos questionários. Descrevemos, primeiramente, os dados apreendidos a partir das respostas dadas pelos professores e, na sequência, pelos alunos.

\subsubsection{Primeiros resultados: em cena, o professor de língua portuguesa}

A interpretação dos dados coletados privilegiou a observação do posicionamento dos professores quanto à concepção de texto dramático, se, de algum modo, as respostas

\footnotetext{
${ }^{39}$ A transcrição desse trecho da entrevista segue as convenções do NURC - Projeto da Norma Urbana Oral Culta (PRETI, 2001). As perguntas realizadas à coordenadora pedagógica estão disponíveis no Anexo IV.
} 
apontaram para a natureza multimodal desse gênero discursivo. Tal encaminhamento levounos a estabelecer um recorte do material sob análise, por isso nem todas as questões do questionário aplicado aos professores são trazidas para discussão e as selecionadas aparecem agrupadas com base no tipo de informação que buscam captar:

a) O texto dramático aproxima-se do modo escritural do texto narrativo.

b) O texto dramático escrito possibilita o trabalho com a modalidade oral da língua.

c) O texto dramático relaciona-se a múltiplos modos de linguagem.

Os dados presentes nos questionários foram redistribuídos quanto aos itens (de agora em diante 'categorias') anteriormente mencionados (a), (b) e (c); para sua descrição e análise, procedemos à seguinte ordenação: transcrição literal da questão elaborada, número de respostas consideradas válidas para cada questão e motivos que levaram a não validação de algumas respostas (deixar em branco, por exemplo); observações feitas por professores em torno da questão (alguns professores expuseram, nas laterais das páginas dos questionários, comentários sobre as questões); e apresentação de tabelas para evidenciar a quantificação das respostas dadas e dar suporte às análises.

A partir das discussões instauradas nas categorias (a), (b) e (c), apresentados a seguir, entendemos ser possível levantar asserções que contribuam, também, para o entendimento da escolarização do texto dramático.

a) O texto dramático aproxima-se do modo escritural do texto narrativo

Em razão de o texto dramático apresentar elementos constitutivos da narrativa literária (história entre personagens desenvolvida em determinado tempo e espaço), propomo-nos a discutir a Questão 03 do questionário, que transcrevemos, a seguir: 


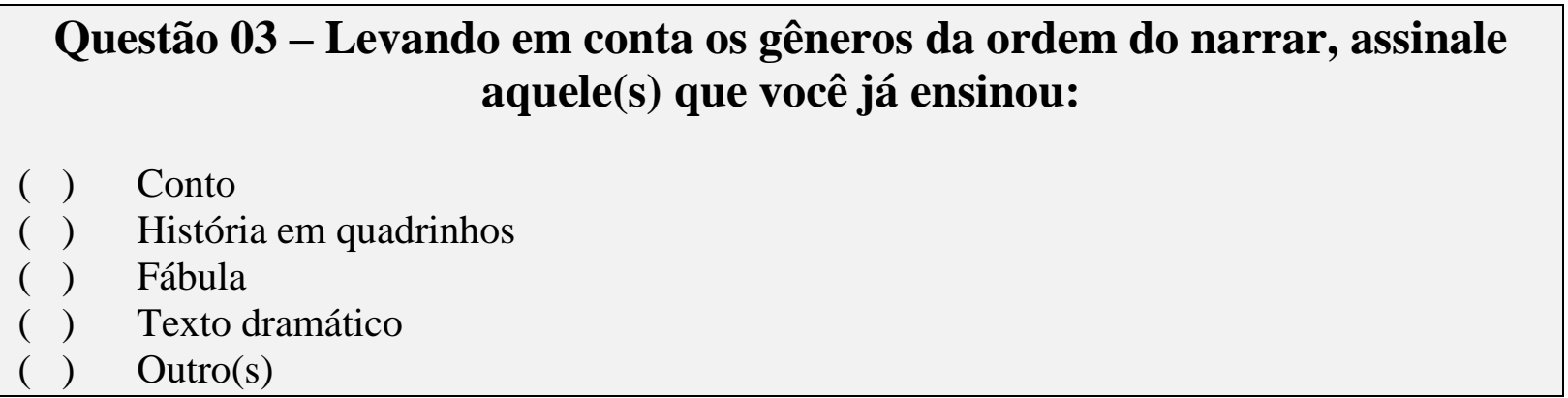

Para essa questão, consideramos noventa e oito (98) respostas válidas e uma (01) não válida. O motivo para a questão ter sido desconsiderada foi o fato de o(a) professor(a) ter preenchido o espaço com sequência diferente daquela solicitada pelo comando, "2-1-4-3-X" (essa ordenação corresponde ao solicitado na primeira pergunta do questionário e pode ser observada no Anexo I deste trabalho).

Alguns professores acrescentaram à opção "Outro(s)" gêneros que não foram listados, mas que, segundo eles, são trabalhados em suas aulas e também pertencem à ordem do narrar, e indicaram, como complementação à resposta, os seguintes textos: QP: 006 - "relatos, resumos de obras literárias e filmes", QP: 049 - “crônicas”, QP: 059 - "crônica”, QP: 098 "poema, crônica", QP: 105 - “crônica, resenha", QP: 106 - "filmes”, QP: 139 - “crônica, lenda", QP: 148 - "autobiografias", QP: 198 - "causo, anedotas, relato". Com base nessas respostas, entendemos que a crônica poderia ter sido acrescentada às opções da Questão 03.

Conforme podemos observar na Tabela 1, a seguir, a maioria dos professores, quarenta e quatro (44), diz trabalhar com todos os gêneros listados nas opções. Poucos professores assinalaram gêneros de forma isolada: somente conto, fábula, história em quadrinhos ou texto dramático.

Tabela 1 - Resultados da Questão 03 (QP)

\begin{tabular}{lc}
\hline Todos & $\mathbf{4 4}$ \\
\hline Todos, exceto texto dramático & $\mathbf{2 0}$ \\
\hline Conto e fábula & $\mathbf{7}$ \\
\hline Conto & $\mathbf{5}$ \\
\hline Conto e texto dramático & $\mathbf{5}$ \\
\hline Todos, exceto fábula & $\mathbf{4}$ \\
\hline História em quadrinhos e fábula & $\mathbf{3}$ \\
\hline Todos, exceto história em quadrinhos & $\mathbf{3}$ \\
\hline
\end{tabular}




\begin{tabular}{lc}
\hline Conto e história em quadrinhos & $\mathbf{3}$ \\
\hline História em quadrinhos & $\mathbf{2}$ \\
\hline Fábula & $\mathbf{1}$ \\
\hline Todos, exceto conto & $\mathbf{1}$ \\
\hline Total de respostas válidas & $\mathbf{9 8}$ \\
\hline
\end{tabular}

A discussão dos resultados apresentados na Tabela 1 pode ser encaminhada a partir da observação do enunciado da questão, "Levando em conta os gêneros da ordem do narrar, assinale aquele(s) que você já ensinou", uma vez que pressupõe o "texto dramático" como texto narrativo, ao apresentá-lo como opção dentre as demais alternativas: "conto", "história em quadrinhos", "fábula" e "outro(s)". Desse ponto de vista, as respostas dadas pelos professores podem revelar: i) concordância ao enunciado, entendendo o texto dramático como texto narrativo e ii) estranhamento desse objeto de ensino no conjunto das opções elencadas.

Quanto à asserção levantada em (i), observamos que cinquenta e sete (57) professores dizem trabalhar com o texto dramático, se somarmos a escolha desse gênero junto às demais opções: “Todos" (44), “Conto e texto dramático" (5), “Todos, exceto fábula” (4), “Todos, exceto história em quadrinhos" (3), “Todos, exceto conto" (1). O número de professores que assinalaram "texto dramático", cinquenta e sete (57), é bastante significativo diante do número total de professores que participaram do questionário, noventa e nove (99).

A comprovação do que se afirma em (ii) dá-se a partir da observação do gênero indicado como opção preferida pelos professores: o conto. Da totalidade dos professores participantes da pesquisa, noventa e um (91) diz considerar o gênero "conto" como exemplo de texto narrativo mais trabalhado em suas aulas. Dentre as opções apresentadas, um número significativo de professores, vinte (20), afirma ensinar todos os gêneros listados na questão inclusive "outros gêneros" - exceto o texto dramático. Esses resultados revelam-nos que há, por um lado, uma identificação com a opção "conto" e, por outro, um estranhamento de "texto dramático" inserir-se em meio às demais opções apresentadas. O texto dramático é indicado como exceção pelos professores, ou porque não se equipara - por alguma razão - aos outros textos narrativos, evidenciando, assim, uma tensão do ponto de vista de sua presença como alternativa a ser assinalada, ou porque não é trabalhado mesmo. 
Baliza-nos essa reflexão os estudos dos pesquisadores brasileiros Cafiero e Corrêa (2003), os quais indicam a presença de gêneros narrativos escritos (o conto, por exemplo) no ensino de língua portuguesa. Os autores assinalam que

Há certos textos que estão presentes na escola, tanto pelas indicações dos professores quanto pelas escolhas dos alunos, que constituiriam, de maneira geral, os cânones de significação. Trata-se das narrativas de aventura, ação ou suspense e das narrativas sentimentais, textos considerados "boas histórias" porque prendem a atenção do leitor jovem com uma linguagem próxima à deles, com personagens comuns - o que permite, muitas vezes, a identificação imediata entre leitor e personagem - e com happy end [...] (CAFIERO; CORRÊA, 2003, p.283).

A pesquisa em torno do ensino de texto dramático em Portugal, realizada por Diegues (2010), revela que esse objeto ainda é estudado no âmbito escolar, de forma incompleta, privilegiando-se uma análise tradicional que não contempla a visão cênica indicada pelas peculiaridades expressas no próprio texto e limitando-se, assim, à caracterização das personagens, do tempo, do espaço, do desenrolar dos acontecimentos ou da identificação do tema. Alguns dados das unidades didáticas analisados no capítulo III (p.95-96) deste trabalho também apontam para atividades dessa ordem, que parecem inserir o texto dramático na esfera literária.

A comparação dos resultados que indicam o texto dramático como opção de gênero da ordem do narrar para o ensino de língua portuguesa, cinquenta e sete (57), e aqueles que não o tomam como opção, vinte (20), permite-nos inferir, primeiramente, que os professores entendem que o texto dramático apresenta uma estrutura textual próxima à estrutura de outros textos narrativos, uma vez que a escolha por essa opção aparece sempre associada aos exemplos mencionados nas demais alternativas (conto, fábula, história em quadrinhos).

Em segundo lugar, se levarmos em conta a hipótese de que esses vinte (20) professores que assinalaram todas as opções, exceto o texto dramático, tenham observado esse gênero como "corpo estranho" no ensino de língua portuguesa, podemos inferir que, para eles, a alternativa apresentada na questão destoa das demais, entendendo que esse gênero pode apresentar uma organização textual diferenciada, circular em outra esfera ou atender a outros propósitos comunicativos - dessemelhantes aos textos narrativos. Em todo caso, o enunciado 
permite-se nos afirmar, apenas, que a resposta aponta para a negação, isto é, tais professores dizem não trabalhar com esse gênero em sala de aula.

A próxima categoria (b) visa a apresentar dados que revelam informações a respeito do texto dramático como gênero potencial para o ensino da oralidade. Para tanto, procedemos à análise das Questões 04, 06 e 09.

b) O texto dramático escrito possibilita o trabalho com a modalidade oral da língua

Primeiramente, apresentamos a Questão 04, a qual nos ajuda a compor os dados que passamos a discutir. Assim, temos:

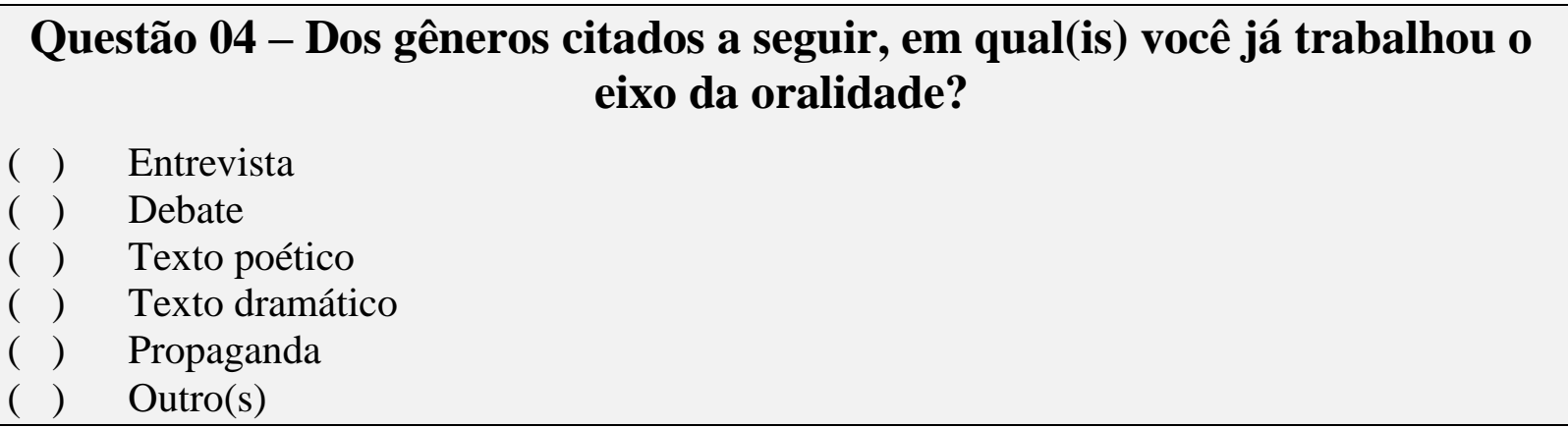

Para essa questão, todas as respostas foram consideradas válidas. Um professor fez a seguinte observação para complementar a opção "Outro(s)": QP: 105 - "Narração de Contos (= contação de histórias)"'. Esse dado aponta, novamente, para a seleção do texto narrativo como referência para o ensino de língua portuguesa, neste caso, para o trabalho com a oralidade.

A Tabela 2, a seguir, apresenta a quantificação das respostas dadas pelos professores participantes desta pesquisa e revela, na primeira leitura, um resultado bastante diluído entre as opções elencadas para a questão, conforme podemos observar: 
Tabela 2 - Resultados da Questão 04 (QP)

\begin{tabular}{lc}
\hline Todos & $\mathbf{1 1}$ \\
\hline Debate, texto poético e texto dramático & $\mathbf{8}$ \\
\hline Todos, exceto propaganda & $\mathbf{7}$ \\
\hline Debate, texto poético e propaganda & $\mathbf{6}$ \\
\hline Debate e texto poético & $\mathbf{6}$ \\
\hline Texto poético e texto dramático & $\mathbf{5}$ \\
\hline Texto poético e propaganda & $\mathbf{5}$ \\
\hline Todos, exceto texto dramático & $\mathbf{5}$ \\
\hline Entrevista, debate e texto poético & $\mathbf{5}$ \\
\hline Somente texto poético & $\mathbf{5}$ \\
\hline Todos, exceto debate & $\mathbf{4}$ \\
\hline Entrevista, debate e texto dramático & $\mathbf{4}$ \\
\hline Debate e texto dramático & $\mathbf{4}$ \\
\hline Entrevista, debate e propaganda & $\mathbf{3}$ \\
\hline Outro(s) & $\mathbf{3}$ \\
\hline Entrevista, texto poético e propaganda & $\mathbf{3}$ \\
\hline Todos, exceto entrevista & $\mathbf{2}$ \\
\hline Entrevista e debate & $\mathbf{2}$ \\
\hline Somente entrevista & $\mathbf{1}$ \\
\hline Somente debate & $\mathbf{1}$ \\
\hline Entrevista, texto poético e texto dramático & $\mathbf{1}$ \\
\hline Entrevista, texto dramático e propaganda & $\mathbf{1}$ \\
\hline Debate, texto dramático e propaganda & $\mathbf{1}$ \\
\hline Texto poético, texto dramático e propaganda & $\mathbf{1}$ \\
\hline Entrevista e texto poético & $\mathbf{1}$ \\
\hline Entrevista e texto dramático & $\mathbf{1}$ \\
\hline Entrevista e propaganda & $\mathbf{1}$ \\
\hline Debate e propaganda & $\mathbf{1}$ \\
\hline Somente propaganda & $\mathbf{1}$ \\
\hline Somente texto dramático & $\mathbf{9 9}$ \\
\hline Total &
\end{tabular}

Novamente, recorremos ao enunciado da questão para conduzir a observação dos resultados obtidos: "Dos gêneros citados a seguir, em qual(is) você já trabalhou o eixo da oralidade?". Esse enunciado pressupõe que a oralidade seja trabalhada em sala de aula e este trabalho seja realizado por meio de gêneros. Diante disso, os professores podiam assinalar, dentre as alternativas: i) a(s) opção(ões) que atenderia(m) a esse pressuposto; ii) a opção outros(s) - entendendo que a oralidade poderia ser trabalhada de outro(s) modo(s) ou por 
meio de outros gêneros ${ }^{40}$ e iii) não assinalar opção alguma - indicando, em hipótese, que a oralidade não é trabalhada.

Observamos, primeiramente, os resultados apresentados na Tabela 2 que incluem o texto dramático, em meio a outros gêneros, como opção para o trabalho com a oralidade em sala de aula. Sob esse ponto de vista, cinquenta (50) professores assinalaram o texto dramático, se somarmos a associação das seguintes respostas: “Todos" (11), "Debate, texto poético e texto dramático" (8), "Todos, exceto propaganda" (7), "Texto poético e texto dramático" (5), "Todos, exceto debate" (4), "Entrevista, debate e texto dramático" (4), "Debate e texto dramático" (4), "Todos, exceto entrevista" (2), "Entrevista, texto poético e texto dramático" (1), "Entrevista, texto dramático e propaganda" (1), "Debate, texto dramático e propaganda" (1), “Texto poético, texto dramático e propaganda" (1), "Entrevista e texto dramático" (1).

Quanto às respostas que excluem o texto dramático, quarenta e nove (49) professores assinalaram outras opções que não esse gênero discursivo: "Debate, texto poético e propaganda" (6), "Debate e texto poético" (6), "Texto poético e propaganda" (5), "Todos, exceto texto dramático" (5), "Entrevista, debate e texto poético" (5), "Somente texto poético" (5), "Entrevista, debate e propaganda" (3), "Outro(s)" (3), "Entrevista, texto poético e propaganda" (3), "Entrevista e debate" (2), "Somente entrevista" (1), "Somente debate" (1), "Entrevista e texto poético" (1), "Entrevista e propaganda" (1), "Debate e propaganda" (1), "Somente propaganda" (1).

Por um lado, esses números sinalizam para um resultado bastante equilibrado quanto à opção ou não pelo texto dramático no trabalho com a oralidade, por outro, revelam o trabalho com a oralidade, independentemente do gênero escolhido. Em outras palavras, o pressuposto de que a oralidade é trabalhada nas aulas de língua portuguesa (conforme indicação do enunciado da questão) foi confirmado.

Se somarmos as opções mais assinaladas, temos que o debate consta em primeiro lugar, seguido do texto poético e, então, do texto dramático. Um traço comum a estes dois gêneros é que ambos, de algum modo, apoiam-se no texto escrito para sua realização, seja no

\footnotetext{
${ }^{40}$ Dolz, Schneuwly e Haller (2004) assinalam para dois tipos de oral: o espontâneo e a escrita oralizada. Segundo os autores, entre essas duas práticas encontram-se todos os orais, dos mais restritos e previsíveis, por sua origem escrita ou sua ritualização social, aos mais imprevisíveis, tanto do ponto de vista de sua estrutura como de seu conteúdo.
} 
suporte para vocalização/recitação de versos ou, ainda, na memorização das falas das personagens. Corroboram essa afirmação os estudos de Schneuwly (2004) que preconizam o ensino de gêneros orais. Segundo o autor:

Não existe "o oral", mas "os orais" em múltiplas formas, que, por outro lado, entram em relação com os escritos, de maneiras muito diversas: podem se aproximar da escrita e mesmo dela depender - como é o caso da exposição oral ou, ainda mais, do teatro e da leitura para os outros (SCHNEUWLY, 2004, p.114, grifo nosso).

A esse respeito, destacamos o trabalho de Fávero, Andrade e Aquino (2002), que busca promover a discussão da fala como modalidade da língua a ser ensinada em correlação à modalidade escrita. Em síntese, as autoras defendem o estudo da variedade de uso da fala e de sua adequação nas diversas situações comunicativas. Um dos tópicos discutidos é o fato de a língua falada ser importante para o entendimento da língua escrita. Nessa perspectiva, o ensino da oralidade merece ser observado junto ao ensino escritural, já que fala e escrita mantêm entre si relações mútuas e intercambiáveis. Para as autoras:

Parece consenso que a língua falada deve ocupar um lugar de destaque no ensino de língua. A motivação para que essa modalidade seja trabalhada com tal relevo se dá, de um lado, porque o aluno já sabe falar quando chega à escola e domina, em sua essência, a gramática da língua. Por outro lado, a fala influencia sobremaneira a escrita nos primeiros anos escolares, principalmente no que se refere à representação gráfica dos sons (FÁVERO; ANDRADE; AQUINO, 2002, p.10-11).

Os resultados da Questão 03, atribuídos ao texto dramático, permite-nos afirmar que muitos professores, cinquenta (50), dizem trabalhar, em suas aulas, o eixo da oralidade, tendo como objeto de ensino esse gênero discursivo. No entanto, o conjunto de dados dessa questão não possibilita conhecer como se dá tal encaminhamento, isto é, se o professor promove, por exemplo, leituras dramatizadas, encenações.

Nesse sentido, selecionamos a Questão 06, a fim de ampliar nossa discussão e, a partir do que foi levantado quanto ao trabalho com a oralidade (junto ao texto dramático, especificamente), observar de que maneira o teatro - remetemo-nos aqui ao eixo 
performático/oral - poderia ser utilizado nas aulas de língua portuguesa. Transcrevemos, assim, a questão sob análise:

\section{Questão 06 - Caso utilize/venha a utilizar o teatro em suas aulas, você o faria para:}

( ) Facilitar a apreensão de um conteúdo dado

( ) Dramatizar um texto literário

( ) Proporcionar aos alunos um momento diferenciado, lúdico, recreativo

( ) Outra(s) finalidade(s)

Para essa questão, consideramos noventa e oito (98) respostas válidas e uma (01) não válida, por ter sido deixada em branco. Os professores também fizeram observações, no sentido de ampliar as opções elencadas: QP: 050 - "Proporcionar desinibição do aluno e melhorar sua eloquência" e, também, para acrescentar itens que remetessem às "Outra(s) finalidade(s)": QP: 144 - "como a expressividade" e QP: 198 - "melhorar a oralidade, trabalhar a desinibição, a insegurança, a autoestima".

A leitura desses dados indica, por um lado, a seleção do teatro para um trabalho voltado à modalidade oral da língua (eloquência, expressividade) e, por outro, sugere professores sensibilizados com o gênero, no sentido de apontar caminhos para o desempenho do aluno em atividades escolares e em potencialidades requeridas pela vida afora: desinibirse, ter segurança, melhorar a estima etc.

Apresentamos, na Tabela 3, a seguir, os dados correspondentes à Questão 06, que revelam os resultados obtidos com relação à finalidade do teatro nas aulas de língua portuguesa: 
Tabela 3 - Resultados da Questão 06 (QP)

\begin{tabular}{lc}
\hline $\begin{array}{l}\text { Dramatizar um texto literário e proporcionar um momento diferenciado, lúdico, } \\
\text { recreativo }\end{array}$ & $\mathbf{1 8}$ \\
\hline Todos & $\mathbf{1 7}$ \\
\hline $\begin{array}{l}\text { Facilitar a apreensão de um conteúdo dado e proporcionar um momento diferenciado, } \\
\text { lúdico, recreativo }\end{array}$ & $\mathbf{1 5}$ \\
\hline Proporcionar aos alunos um momento diferenciado, lúdico, recreativo & $\mathbf{1 5}$ \\
\hline Dramatizar um texto literário & $\mathbf{1 4}$ \\
\hline Outra(s) finalidade(s) & $\mathbf{1 1}$ \\
\hline Facilitar a apreensão de um conteúdo dado & $\mathbf{5}$ \\
\hline Facilitar a apreensão de um conteúdo dado e dramatizar um texto literário & $\mathbf{4}$ \\
\hline Total & $\mathbf{9 9}$ \\
\hline
\end{tabular}

A análise dos resultados obtidos com essa questão faz-se a partir da observação da palavra "teatro", indicada no enunciado, a qual pressupõe uma prática discursiva ritualizada, conhecida do ponto de vista sociocultural. Na hipótese de ser trabalhado em sala de aula, interessa-nos conhecer a razão pela qual os professores o fazem, quer dizer: i) se há correlação do uso do teatro com o gênero texto dramático ou ii) se há outras motivações para tal.

Com relação ao que se propõe em (ii), os números apresentados na Tabela 3 permitem concluir que a maioria dos professores participantes desta pesquisa, sessenta e cinco (65), se somarmos esta opção associada às demais, elege como principal finalidade do teatro "Proporcionar um momento diferenciado, lúdico, recreativo". A alternativa parece apontar para as possibilidades de socialização que o fazer teatral pode propiciar no contexto escolar, conforme indicam estudos de pesquisadores que buscam promover o encontro entre teatro e educação:

[...] o teatro mais que uma "ferramenta pedagógica" na sala de aula, exerce uma função social que visa a levar o sujeito não apenas à emoção, mas à reflexão. Trabalhar o teatro na sala de aula é promover o resgate da cidadania, é uma forma de ampliar o universo cultural e social do estudante (CALZAVARA, 2009, pp.153-154, grifo nosso).

Nessa direção, Granero (2011) também considera o teatro como atividade que pode despertar os alunos para observação de si mesmo e do outro, de modo a motivá-los a 
aprofundar-se em suas próprias histórias de vida e a desenvolver a capacidade de expressar seus sentimentos de forma positiva, com respeito e colaboração.

As indicações que apontam "Outra(s) finalidade(s)", citadas anteriormente, também direcionam o teatro para esse fim, qual seja: a socialização entre alunos, professores e sociedade. A esse respeito, Diegues (2010, p.26) salienta que o texto dramático - e de modo mais amplo, o teatro - pode promover "a auto-confiança, o que leva a criança ou o jovem a auto-descobrir-se, a afirmar-se e a relacionar-se com os outros e com o meio".

Quanto ao item (i), observamos que trinta e nove (39) professores associaram a opção "Dramatizar um texto literário" a outras opções, e catorze (14) professores indicaram, exclusivamente, essa opção. Se somarmos esses dois resultados, temos um número expressivo de cinquenta e três (53) professores que afirmam trabalhar o teatro em associação a um texto escrito. A esse respeito, os estudos teatrais têm muito a acrescentar, pois assinalam a importância de pensar a representação cênica como essencial do texto dramático. Para Chacra (2010, p.58),

[...] a peça enquanto produto literário permanece no domínio de um território fechado e individual. Somente quando ela passa a funcionar dentro da maquinaria complexa da vida teatral, isto é, quando passa a ser representada em ato pelos atores e assistida pelos espectadores, é que encontrará o sentido de sua existência. (grifo do autor)

Entendemos que os resultados indicativos da finalidade do teatro como "Dramatização de um texto literário" sugerem a abordagem da língua oral a partir de uma base escritural. Cabe destacar, nesse sentido, o posicionamento de Diegues (2010, p.37), ao indicar a relevância de os alunos reconhecerem que a representação cênica vincula-se ao texto dramático e, segundo a autora, é igualmente importante que também identifiquem no texto as marcas que testemunham essa interdependência.

Nos estudos da linguagem, as relações fala-escrita foram amplamente discutidas por Marcuschi $(2003$, 2008). De forma análoga à contribuição desse linguista, podemos entender texto dramático e representação cênica como práticas textuais pertencentes a um continuum tipológico dos gêneros discursivos, em que se situam as modalidades falada e escrita da língua. 
A opção "Facilitar a apreensão de um conteúdo dado" foi a terceira alternativa mais assinalada. A esse respeito, destacamos a pesquisa de Hauer (2005), que objetivou estabelecer um parâmetro de comparação entre o ensino tradicional, centrado basicamente na exposição significativa dos conteúdos, e um ensino que incorpore a linguagem teatral como método de aprendizagem.

Esse estudo, de caráter experimental, encontra sua contribuição no tratamento científico dispensado a dados constantemente presentes no discurso do senso comum (escolar): o teatro é utilizado na prática docente para mediar o aprendizado de conteúdos das diversas disciplinas escolares. Para discussão, Hauer (2005) seleciona o conteúdo "Revolução Russa" da disciplina História e observa a compreensão de alunos que tiveram a experiência com o teatro e daqueles que não tiveram. Os resultados de seu trabalho apontam para o fato de que:

[...] a linguagem teatral, através da riqueza de seus recursos, disponibiliza ao aluno uma maior quantidade de mediações semânticas, as quais acrescentam às mediações estritamente conceituais um sentido mais amplo, permitindo dessa maneira que o aluno se aproprie do conhecimento de maneira mais significativa (HAUER, 2005, p.243).

Nesse sentido, as análises da Questão 06 autorizam-nos afirmar que o trabalho com o teatro na aula de língua portuguesa permite ao professor usá-lo para fins de socialização do grupo escolar, ou para um objetivo restrito, o qual parte da utilização da modalidade escrita (texto literário, dramático) como apoio para utilização da modalidade oral (dramatização) ou como "recurso metodológico" para aquisição ou fixação de conteúdos; enfim, esses dados apontam para os modos como o teatro pode circular no ambiente escolar - produto sociocultural, objeto de ensino e método.

Tendo em vista essas possibilidades, interessa-nos conhecer as atividades que podem ser solicitadas na hipótese de o professor trabalhar com a peça de teatro nas aulas de língua portuguesa e observar se a ênfase é dada à produção escrita ou à produção oral ou, ainda, se há um equilíbrio na produção das duas modalidades. Com intuito de assegurar tal discussão, selecionamos a Questão 09, descrita, a seguir: 


\section{Questão 09 - Se o professor de língua portuguesa se decidir a trabalhar com a peça teatral, você acredita que ele poderia solicitar aos alunos:}

( ) A leitura silenciosa de peças teatrais

( ) A leitura dramatizada de peças teatrais

( ) A produção escrita de peças teatrais ou fragmentos (cenas)

( ) A encenação de uma peça teatral

Para essa questão, todas as respostas foram consideradas válidas. Apenas uma observação foi feita, com objetivo de ampliar a última alternativa: QP: 158 - “A encenação de uma peça teatral (fragmentos)". Neste caso, o professor optou por registrar que não promove a encenação completa de uma peça, mas de fragmentos. Essa ressalva vai ao encontro das propostas de encenação observadas na maioria das unidades didáticas analisadas no capítulo III (p.119-122), que buscam oportunizar a dramatização de fragmentos de peças já existentes ou de cenas criadas pelos alunos na atividade de produção escrita. Apresentamos, na sequência, a Tabela 4, que indica os resultados das respostas dadas à Questão 09:

Tabela 4 - Resultados da Questão 09 (QP)

\begin{tabular}{lc}
\hline Todas & $\mathbf{2 7}$ \\
\hline Todas, exceto a leitura silenciosa de peças teatrais & $\mathbf{2 6}$ \\
\hline A encenação de uma peça teatral & $\mathbf{1 4}$ \\
\hline A leitura dramatizada de peças teatrais & $\mathbf{7}$ \\
\hline A leitura dramatizada de peças teatrais e a encenação de uma peça teatral & $\mathbf{7}$ \\
\hline $\begin{array}{l}\text { A produção escrita de peças teatrais ou fragmentos (cenas) e a encenação de uma } \\
\text { peça teatral }\end{array}$ & $\mathbf{7}$ \\
\hline A produção escrita de peças teatrais ou fragmentos (cenas) & $\mathbf{3}$ \\
\hline A leitura silenciosa de peças teatrais e a leitura dramatizada de peças teatrais & $\mathbf{2}$ \\
\hline Todas, exceto a produção escrita de peças teatrais ou fragmentos (cenas) & $\mathbf{2}$ \\
\hline A leitura silenciosa de peças teatrais e a encenação de uma peça teatral & $\mathbf{1}$ \\
\hline $\begin{array}{l}\text { A leitura dramatizada de peças teatrais e a produção escrita de peças teatrais ou } \\
\text { fragmentos (cenas) }\end{array}$ & $\mathbf{1}$ \\
\hline Todas, exceto a leitura dramatizada de peças teatrais & $\mathbf{1}$ \\
\hline Todas, exceto a encenação de uma peça teatral & $\mathbf{1}$ \\
\hline A leitura silenciosa de peças teatrais & $\mathbf{0}$ \\
\hline Total & $\mathbf{9 9}$ \\
\hline
\end{tabular}

De início, atentemo-nos aos números correspondentes à segunda linha da Tabela 4, que sinalizam a não indicação da leitura silenciosa como atividade a ser desenvolvida com 
esse gênero discursivo, na opinião de vinte e seis (26) professores. É possível interpretar essa escolha de duas maneiras: i) do ponto de vista da formulação das alternativas - ao observar, dentre as opções elencadas, a leitura silenciosa e, na sequência, a dramatizada, a escolha pode ter sido direcionada pelo caráter eliminatório, isto é, ou o professor optou por uma (leitura silenciosa), ou por outra (leitura dramática) e ii) do ponto de vista da formulação do enunciado - ao responder à questão, o professor não cogitou considerar a leitura silenciosa como proposta de atividade para esse gênero discursivo.

Cabe destacar, nessa direção, que, no domínio dos estudos da formação do leitor, Nazareth (2008) salienta que a leitura silenciosa de um texto teatral, em relação a outros gêneros, pode ser um exercício de imaginação vital, pois a natureza do gênero dramático atribui-lhe uma particularidade, a qual associa a possibilidade de encenação às possibilidades de interpretação. Conforme entendemos, a leitura silenciosa de uma peça teatral pode levar o aluno a apreender diversas características do gênero e partilhar detalhes presentes somente no texto escrito - é o caso da observação de rubricas e indicações cênicas, por exemplo.

O número que corresponde a todas as opções, vinte e sete (27) - primeira linha da Tabela 4 - merece atenção, pois praticamente se iguala ao resultado mencionado anteriormente. Em outras palavras, parte dos professores diz trabalhar com todas as atividades elencadas e outra parte também diz trabalhar com todas as atividades, exceto a leitura silenciosa. O resultado parece-nos equilibrado e pode sinalizar para tensões que a versão escolar desse gênero discursivo pode instaurar, do ponto de vista da seleção das atividades, no contexto de ensino de língua portuguesa.

Dentre as opções mais assinaladas, encontra-se a encenação de peças teatrais e, em segundo lugar, a leitura dramática. Ressaltamos que ambas as atividades pressupõem o uso da modalidade oral língua. Entendemos, assim, que o trabalho com a oralidade, apontado nos resultados obtidos com a Questão 04 (seleção do texto dramático como gênero potencial para esse fim) e com a Questão 06 (seleção da dramatização de textos literários como finalidade do teatro), é aqui reforçado em razão da escolha (como primeira e segunda opções) de duas atividades que abordam a modalidade oral da língua: encenação e leitura dramática.

Quanto à encenação, oitenta e quatro (84) professores afirmam propor atividades dessa ordem, conforme a totalidade dos resultados apresentados na Tabela 4, que associam essa opção às demais: “Todas” (27), “Todas, exceto a leitura silenciosa de peças teatrais” (26), “A 
encenação de uma peça teatral" (14), "A leitura dramatizada de peças teatrais e a encenação de uma peça teatral” (7), "A produção escrita de peças teatrais ou fragmentos (cenas) e a encenação de uma peça teatral” (7), “Todas, exceto a produção escrita de peças teatrais ou fragmentos (cenas)" (2), "A leitura silenciosa de peças teatrais e a encenação de uma peça teatral” (1), “Todas, exceto a leitura dramatizada de peças teatrais".

A seleção da atividade "encenação de uma peça teatral" como primeira opção, para a maioria dos professores de língua portuguesa questionados nesta pesquisa converge com os postulados teóricos dos estudos teatrais que indicam o texto dramático não como um texto para ser lido, mas para ser encenado em um palco. Assim, temos que:

\begin{abstract}
A base do teatro é a fusão do ator com a personagem, a identificação de um eu com outro eu - fato que marca a passagem de uma arte puramente temporal e auditiva (literatura) ao domínio de uma arte espaço-temporal ou audio-visual. O status da palavra modifica-se radicalmente. Na literatura, são as palavras que medeiam o mundo imaginário. No teatro são os atores/personagens (seres imaginários) que medeiam a palavra. Na literatura, a palavra é a fonte do homem (das personagens). No teatro o homem é a fonte da palavra (ROSENFELD, 1993, p.21-22).
\end{abstract}

Em relação à leitura dramática, um número expressivo de professores, setenta e três (73), assinalou essa opção associada a outras. Para esses professores, esse tipo de leitura parece ser adequado às atividades que possibilitam o trabalho com a peça teatral nas aulas de língua portuguesa. Esse dado aponta para a distinção entre texto literário e texto dramático, proposta pelos estudiosos do teatro. Indicamos, nessa direção, o posicionamento de Koudela (2010, p.105):

Denominamos o universo criado através de palavras de texto literário, enquanto o universo criado através da materialização cênica (ações e imagens físicas que podem ser de ordem dramática, plástica ou musical) será denominado texto teatral. A diferença entre texto literário e texto teatral reside na relação criada com o espectador e/ou participante da ação dramática. As ações e imagens emergem fisicamente na construção do texto teatral, enquanto que no texto literário elas permanecem interiorizadas na mente do leitor. 
Ao considerar o texto dramático como texto teatral (ou texto para o teatro) - não como texto literário -, parece ser possível realizar leituras dramáticas, que se constituem de uma série de tentativas de dizer, de diversos modos, e privilegiam, sobremaneira, a materialidade linguística durante os primeiros contatos com o texto. Conforme assegura Ryngaert (1995, p.50):

\begin{abstract}
Entre as instruções mecânicas, experimentam-se todas as oposições de ritmo, de articulação, de nível sonoro: lê-se muito depressa ou muito devagar, berrase, sussurra-se ou salmodia-se; procura-se terminar o mais rápido possível ou, pelo contrário, saborear todas as harmonias e asperezas; tentam-se acentos e acentuações; lê-se sozinho ou com várias pessoas, passando o texto de uma para outra; variam-se os leitores e os enunciadores, com o mínimo de a priori possível. Até se parodia, talvez chegando ao exagero.
\end{abstract}

Conforme os resultados apresentados na Tabela 4, a produção escrita de uma peça teatral foi a terceira opção mais assinalada - associada às demais alternativas -, para sessenta e seis (66) professores. Em relação a esses dados, buscamos respaldo nas contribuições de Lisbôa (1998), no que se refere à compreensão do texto dramático como gênero fonte e destino da representação, gênero que, embora situado na literatura, exige ou envolve a teatralidade. Com isso, parece-nos possível entender que, ao ser solicitado a produzir a escrita de um texto dramático, o aluno pode ser levado a observar uma estrutura composicional diversa, que permite ajudá-lo a refletir sobre a existência de múltiplos modos de produção de linguagem: um tipo de escrita que convoca para cena.

Quanto à apreensão de dados que pudessem apontar para a concepção de texto dramático como gênero discursivo multimodal, selecionamos para discussão as Questões 11, 12 e 13, descritas no próximo item (c).

c) O texto dramático relaciona-se a múltiplos modos de linguagem

A Questão 11 buscou investigar, junto aos professores participantes desta pesquisa, quais competências estão relacionadas ao trabalho com o texto dramático nas aulas de língua portuguesa. Assim, temos: 


\section{Questão 11 - Para você, esse gênero textual (texto dramático) potencializa qual(is) competência(s) do aluno?}

( ) Linguística: conhecer a gramática e o léxico de uma língua, para nela produzir enunciados gramaticais aceitáveis

( ) Textual/Discursiva: reconhecer um gênero, atribuir-lhe sentidos

( ) Situacional: depreender a situação em que se dá a comunicação e o(s) parceiro(s) do ato comunicativo

( ) Expressiva: apreender elementos paralinguísticos (voz, gestos, postura, entonações, expressões faciais e corporais)

Para essa questão, consideramos noventa e oito (98) respostas válidas e uma (01) não válida, por ter sido deixada em branco. Assim, voltamos nosso olhar para os dados da Tabela 5, que apresenta a quantificação das respostas dos professores.

Tabela 5 - Resultados da Questão 11 (QP)

\begin{tabular}{lc}
\hline Todas & $\mathbf{2 5}$ \\
\hline Expressiva & $\mathbf{2 4}$ \\
\hline Todas, exceto a linguística & $\mathbf{1 6}$ \\
\hline Situacional e expressiva & $\mathbf{1 3}$ \\
\hline Textual/Discursiva e expressiva & $\mathbf{1 1}$ \\
\hline Linguística e expressiva & $\mathbf{3}$ \\
\hline Textual/Discursiva & $\mathbf{2}$ \\
\hline Linguística e situacional & $\mathbf{2}$ \\
\hline Linguística e textual/discursiva & $\mathbf{1}$ \\
\hline Todas, exceto a expressiva & $\mathbf{1}$ \\
\hline Linguística & $\mathbf{0}$ \\
\hline Situacional & $\mathbf{0}$ \\
\hline Total de respostas válidas & $\mathbf{9 8}$ \\
\hline
\end{tabular}

Dentre as alternativas mais assinaladas, noventa e dois (92) professores selecionaram a competência expressiva, associada a outras opções. Desses professores, vinte e quatro (24) assinalaram somente essa competência, e vinte e cinco (25) assinalaram todas, inclusive a expressiva. A interpretação desses resultados pode remeter à seguinte hipótese: i) ao se posicionarem em relação às competências, a maioria dos professores tomou como referência a produção oral do gênero texto dramático. 
Tendo em vista o que se afirma em (i), recorremos, para análise, à complementação da alternativa "competência expressiva", que indica a apreensão de elementos paralinguísticos: voz, gestos, postura, entonações, expressões faciais e corporais. A seleção dessa alternativa por parte da maioria dos professores de língua portuguesa participantes dessa pesquisa, noventa e dois (92), revela-nos uma concepção de texto dramático oralizado. Os itens dispostos nos parênteses da alternativa registram a possibilidade de um trabalho intrinsecamente relacionado à performance teatral, voltado para o uso do corpo e da voz para multimodalidade.

A asserção elaborada em (i) pode ser confirmada, ainda, pela leitura dos resultados obtidos de dezesseis (16) professores que apontaram para todas as competências como alternativas, exceto a linguística. Para iniciar esta reflexão, retomamos o posicionamento de Fiorin (1996, p.32) quanto à concepção de competência linguística. Nas palavras do autor, é a competência básica para produzir um enunciado: "o falante deve conhecer a gramática (sistemas fonológico, morfológico e sintático) e o léxico de uma língua para nela produzir enunciados gramaticais aceitáveis".

Nesse sentido, o fato de muitos professores de língua portuguesa terem assinalado como primeira opção a competência expressiva ou reforçado a não consideração da competência linguística para o trabalho com o texto dramático revela, a nosso ver, uma tensão diretamente relacionada à historicidade da forma escolar, que elege a escrita (e não o oral ou multimodal) como prática de excelência para sistematização do ensino, aquisição, compreensão e socialização dos saberes. Vincent, Lahire e Thin (2001, p.28) assim se referem quanto à forma escolar:

A escola e a pedagogização das relações sociais de aprendizagem estão ligadas à constituição dos saberes estruturais formalizados, saberes objetivados, delimitados, codificados, concernentes tanto ao que é ensinado quanto à maneira de ensinar, tanto às práticas dos alunos quanto à prática dos mestres.

Parece-nos possível admitir, assim, um estranhamento da presença do texto dramático na escola, quanto ao que se apresenta como tradicionalmente predominante em relação ao conteúdo da disciplina Língua Portuguesa: a forma escritural e as leis que regem a gramática 
da língua. A concepção de texto dramático parece estar relacionada - do que foi possível apreender das respostas dos professores participantes desta pesquisa - mais à dimensão performática, que linguística, pois a tradição escolar não permite associá-lo ao ensino de língua.

A fim de ampliar essa discussão, passamos a observar os dados apreendidos da Questão 12, que solicitava ao professor, caso este respondesse afirmativamente, a indicação de conteúdos linguísticos (gramaticais) que poderiam ser trabalhados com esse gênero discursivo. Assim, temos:

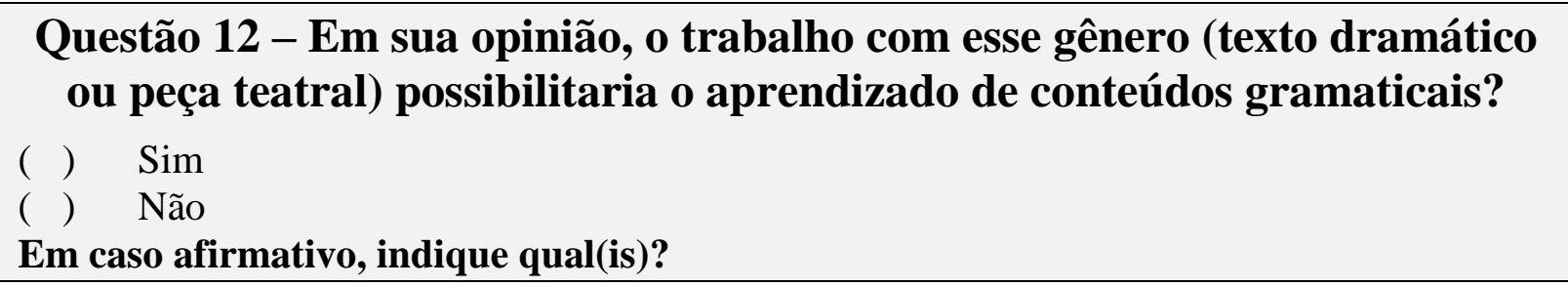

Para essa questão, consideramos noventa e quatro (94) respostas válidas e cinco (05) não válidas. Os motivos para as questões terem sido desconsideradas foram os seguintes: o professor deixou a questão em branco, assinalou a opção "sim”, mas não justificou ou, ainda, assinalou as duas opções e não justificou nenhuma delas. A maioria dos professores assinalou a opção "sim", conforme podemos conferir na Tabela 6:

Tabela 6 - Resultados da Questão 12 (QP)

\begin{tabular}{lc}
\multicolumn{2}{c}{ Tabela 6 - Resultados da Questão 12 (QP) } \\
\hline Sim & $\mathbf{7 9}$ \\
\hline Não & $\mathbf{1 5}$ \\
\hline Total de respostas válidas & $\mathbf{9 4}$ \\
\hline
\end{tabular}

Um número significativo de professores, setenta e nove (79), assinalou a possibilidade de o gênero texto dramático proporcionar o aprendizado de conteúdos gramaticais. No campo destinado para complementação da resposta, alguns professores mencionaram conteúdos particulares: QP: 088 - “Concordância nominal e verbal, pronomes, verbos, advérbios e todas as classes gramaticais", QP: 197 - “Todos os conteúdos gramaticais, mas os relevantes são as 
concordâncias nominais e verbais". Outros professores, porém, não especificaram o conteúdo, apresentando sugestões genéricas: QP: 012 - "É possível trabalhar toda gramática”, QP: 063 “Todos. Qualquer gênero pode se abordar a gramática", QP: 099 - "Todos, pois ao termos uma peça teatral em mãos podemos analisá-la de maneira profunda e praticar o uso do 'Português' em nossa vida diária” e QP: 167 - “Qualquer conteúdo gramatical que o professor queira abordar".

Um conteúdo mencionado por grande parte dos professores foi a pontuação, conforme revelam as respostas de alguns: QP: 044 - "Pontuação (por conta da entonação), expressão oral (uso correto de algumas palavras)", QP: 053 - "Pontuação expressiva, vocativo, ortoepia (pronúncia adequada dos fonemas na variedade padrão), prosódia, acentuação e entonação adequada dos fonemas na variedade padrão, concordância verbal, variedades linguísticas, etc.”, QP: 086 - “O trabalho com o texto dramático ou teatral possibilita ao aluno o entendimento do texto, pontuação, ortografia, maiúsculas/minúsculas, verbos, vocabulário" e QP: 200 - "Discurso direto (pontuação) entre outros".

Os itens gramaticais indicados nessas respostas nos fazem refletir sobre as possibilidades de se associar o desenvolvimento da competência linguística à produção escrita do texto dramático. Em outras palavras, parece-nos que, especialmente a pontuação (aqui também incluído o emprego de maiúsculas e minúsculas) e o uso da vírgula para marcação do vocativo e a observação das marcas do discurso direto - que na produção escrita do texto dramático merecem ser adaptadas - são conteúdos que comportam a estrutura composicional desse gênero discursivo e podem ser observados na leitura de um texto dramático ou, na escrita, no contexto de adaptação de um texto narrativo para um tex to teatral.

O trabalho com a pontuação do texto dramático escrito aponta, também, para a percepção da oralidade, conforme assinalaram os próprios professores: "pontuação (por conta da entonação)" e "pontuação expressiva". Entendemos, assim, que há no texto dramático escrito componentes linguísticos que favorecem sua projeção oral: uso dos parênteses para indicar as rubricas, emprego dos sinais de pontuação para evidenciar a entonação das falas, por exemplo. Nessa direção, é válido destacar o posicionamento de Corrêa (2004), do qual também compartilhamos: parece ser mais fecundo pensar na importância de estudar a escrita e abordá-la do ponto de vista de sua sempre e dada e, ao mesmo tempo, inédita relação com a oralidade. 
Alguns professores afirmaram que todos os conteúdos gramaticais são passíveis de estudo, mas fizeram ressalvas: QP: 028 - "Depende a forma de trabalho proposta, se houver a comparação, a orientação gramatical e a observação de aspectos relevantes no texto, os conteúdos gramaticais poderão ser abordados" e QP: 163 - "Não seria o objetivo essencial ensinar gramática através deste gênero, porém sempre é possível explorar linguisticamente qualquer texto".

A esse respeito, temos que, para este professor, há outra finalidade - que não o estudo gramatical - que parece ser mais ajustada ao se pensar no trabalho com o texto dramático na aula de língua portuguesa. É significativo apresentar, nesse sentido, respostas de outros professores que também fizeram ressalvas quanto aos conteúdos gramaticais e expuseram suas opiniões em torno do que poderia ser explorado no trabalho com o texto dramático. Assim, temos: QP: 036 - "Todos os gêneros textuais possibilitam o trabalho formal da gramática, mas acredito que o gênero dramático abre espaço para outras atividades com a língua portuguesa, sobretudo com a oralidade e a expressão corporal, que, a meu ver, são aspectos extremamente importantes para a comunicabilidade", QP: 050 - "De algum modo sim, porque é o exercício da Língua que está inserido, mas o teatro vai além disto, porque compreende o ser humano em vários aspectos de sua vida", e QP: 145 - "O teatro objetiva a interação dos atores com o público, assim sendo, o aprendizado se dá de acordo com o conteúdo da peça”.

A centração das respostas mencionadas por esses professores parece refletir o eixo performático desse gênero discursivo, em uma palavra, sua produção oral. Conforme observamos, esses dados revelam a sensibilidade para a percepção das múltiplas semioses que compõem a produção oral desse gênero discursivo (trabalhar "a oralidade", "a expressão corporal", conforme assinalaram os professores); para eles, tais possibilidades estão relacionadas, de modo amplo, à comunicação e à interação, propiciada pelo contato entre atores e público.

Na questão seguinte, buscamos conhecer as peças teatrais que os professores de língua portuguesa participantes desta pesquisa elegem para o trabalho em sala de aula. Para apreender essa informação, selecionamos a Questão 13, a seguir: 


\section{Questão 13 - Em suas aulas, você já trabalhou com alguma peça de teatro? ( ) $\operatorname{Sim}$ ( ) Não Se a resposta for "sim", indique, por gentileza, quais foram selecionadas:}

Para essa questão, consideramos noventa e sete (97) respostas válidas e duas (02) não válidas. Os motivos para as questões terem sido desconsideradas foram estes: o professor deixou a questão em branco ou assinalou a opção "sim", mas não citou exemplo(s). A maioria dos professores, sessenta e cinco (65), diz trabalhar com peças teatrais nas aulas de língua portuguesa, conforme observamos na Tabela 7 , a seguir:

Tabela 7 - Resultados da Questão $13(Q P)$

\begin{tabular}{ll}
\hline Sim & 65 \\
\hline Não & 32 \\
\hline Total de respostas válidas & 97 \\
\hline
\end{tabular}

Dado o conjunto de respostas afirmativas, a maioria dos professores registrou obras centradas, principalmente, em adaptações de textos narrativos, por exemplo, contos de fadas e fábulas: QP: 082 - “O Chapeuzinho Vermelho”, QP: 093 - “O lobo e os sete cabritinhos” e QP: 147 - "Foram peças infantis que priorizavam as histórias infantis, os contos e fábulas", ou, ainda, na dramatização de textos de autores consagrados da literatura brasileira, como, QP: 097 - "Negrinha - Monteiro Lobato" e QP: 106 - "Contos de Machado de Assis". Esses resultados oferecem indícios do que é texto dramático escolar, do ponto de vista de sua produção oral: textos adaptados de narrativas literárias, de alta circulação na escola: a fábula, o conto, por exemplo.

Alguns textos dramáticos citados pelos professores retomam os textos disponíveis nos livros didáticos de língua portuguesa, conforme assinalam os exemplos, QP: 033 - "Lua nua de Leilah Assunção, mais recentemente por estar no livro didático" e QP: 050 - "No livro do $8^{\circ}$ ano, há uma peça entre o casal Lúcio e Sílvia, os alunos gostam de interpretá-la”. A discussão em torno do texto dramático em livros didáticos de língua portuguesa, apresentada no capítulo III deste trabalho, dialoga com o discurso desses professores, uma vez que aponta 
para a possibilidade de o texto apresentado nos manuais de ensino constituir referência para encenações.

Verificamos, também, nas respostas dos professores, a predominância de títulos que remetem a autores conhecidos da literatura brasileira, como QP: 010 - "Pluft, o fantasminha", de Maria Clara Machado, QP: 041 - “O Auto da Barca do Inferno”, de Gil Vicente, QP: 076 "Feiurinha (O fantástico mistério de Feiurinha), O Santo e a Porca", de Pedro Bandeira e Ariano Suassuna, respectivamente e QP: 048 - "A falecida, O auto da compadecida", de Nelson Rodrigues e Ariano Suassuna, respectivamente. A seleção dessas obras parece confirmar a recorrência pelo cânone literário na prática escolarizada do texto dramático, em propostas de dramatização de peças teatrais, nas aulas de língua portuguesa.

Alguns professores assinalaram, ainda, a representação cênica de peças autorais, como confirmam os exemplos a seguir: QP: 069 - "Trabalhei, mas com peças produzidas pelos próprios alunos", QP: 138 - "Normalmente os meus alunos escrevem as peças em grupo, ensaiam e apresentam" e QP: 145 - "Textos produzidos pelos alunos ou baseados em leituras".

Em síntese, observamos quatro possibilidades para a escolha de peças teatrais no trabalho com esse gênero discursivo nas aulas de língua portuguesa: i) adaptação de narrativas literárias; ii) textos teatrais disponibilizados no livro didático; iii) obras canônicas de teatro e iv) textos escritos pelos alunos. Essas opções revelam muito a respeito da versão escolarizada do texto dramático, pois informam a recorrência, via de regra, pelo texto escrito como apoio à encenação e apresentam, ainda, suportes diversos para aquisição dessa materialidade linguística: livros de literatura infantil ou infanto-juvenil, sobretudo de contos e fábulas, livro didático de língua portuguesa, livros de teatro, textos produzidos em sala de aula (em grupos).

Acrescentamos a essa discussão o registro de alguns professores quanto aos resultados obtidos com a produção oral do texto dramático nas aulas de língua portuguesa. Assim, temos QP: 140 - "Não neste ano. Já fiz, com uma turma de $8^{\text {a }}$ série (hoje seria $9^{\circ}$ ano), a montagem de uma peça que adaptamos do conto A Igreja do Diabo, de Machado de Assis. A proposta foi de trazer a temática para a atualidade. Penso que ficou bom o resultado alcançado, os alunos ficaram felizes com o resultado e nós apresentamos no anfiteatro da escola” e QP: 197 “Atualmente não, mas já trabalhei muito com teatro no passado. Um que me marcou e me surpreendeu foi sobre o estudo de texto do Natal. Produzi um texto simples em teatro 
trabalhando todos os significados dela. Foi fantástico. Claro que isso não depende do professor e sim dos alunos". Esses dados indicam que o teatro perpassa as práticas escolares e, de algum modo, encontra tempo, espaço e voz nas aulas de língua portuguesa. Os professores também relataram que fizeram peças em anos anteriores, "já trabalhei muito com teatro no passado" e ressaltaram os resultados positivos desse trabalho, "os alunos ficaram felizes", "foi fantástico".

Diante do exposto, interessa-nos conhecer as experiências dos alunos participantes desta pesquisa em relação ao fazer teatral, em outras palavras, suas experiências como produtor (dramaturgo, ator) e receptor (leitor, espectador) de textos dramáticos. Tratamos desse assunto na próxima seção.

\subsubsection{Mais resultados: a performance dos alunos}

Passamos a observar os dados do questionário elaborado para os alunos dos $8^{\text {os }}$ e $9^{\text {os }}$ anos do Colégio Estadual Rodrigues Alves (Maringá-PR). Para quantificação das respostas, esclarecemos que, da totalidade de alunos de cada turma, consideramos apenas aqueles que estavam presentes no dia da aplicação do questionário, conforme indicamos na Tabela 8 , no item "adesão (\%)":

Tabela 8 - Adesão ao questionário (alunos)

\begin{tabular}{lcccccccccc}
\hline & $\mathbf{8}^{\circ} \mathbf{A}$ & $\mathbf{8}^{\circ} \mathbf{B}$ & $\mathbf{8}^{\circ} \mathbf{C}$ & $\mathbf{8}^{\circ} \mathbf{D}$ & $\mathbf{8}^{\circ} \mathbf{E}$ & $\mathbf{9}^{\circ} \mathbf{A}$ & $\mathbf{9}^{\circ} \mathbf{B}$ & $\mathbf{9}^{\circ} \mathbf{C}$ & $\mathbf{9}^{\circ} \mathbf{D}$ & $\mathbf{9}^{\circ} \mathbf{E}$ \\
\hline Total de alunos & 27 & 28 & 19 & 21 & 19 & 31 & 34 & 24 & 25 & 25 \\
\hline Presentes & 14 & 17 & 12 & 18 & 17 & 23 & 22 & 16 & 18 & 20 \\
\hline Adesão (\%) & $52 \%$ & $61 \%$ & $63 \%$ & $86 \%$ & $89 \%$ & $74 \%$ & $65 \%$ & $67 \%$ & $72 \%$ & $80 \%$ \\
\hline
\end{tabular}

O encaminhamento das análises decorre da seleção de cinco (05), do total de sete (07) questões que compõem o questionário, em razão de se querer observar o conhecimento que os alunos têm a respeito do texto dramático, do ponto de vista da experimentação de práticas (de leitura, escrita e de natureza multimodal) que envolvem esse gênero discursivo. Em outras palavras, a interpretação dos dados realizou-se a partir do agrupamento das respostas dadas 
pelos alunos com base nos papéis que eles podem assumir no contexto de produção e recepção do texto dramático (escrito e oralizado), quais sejam:
a) Aluno-leitor.
b) Aluno-dramaturgo.
c) Aluno-espectador.
d) Aluno-ator.

Cabe destacar que as cinco (05) questões selecionadas para discussão desses itens (a), (b), (c) e (d) não aparecem ordenadas conforme constam do questionário aplicado aos alunos; elas foram ajustadas de acordo com a informação que procuram apreender. Para tanto, indicamos os resultados em gráficos organizados de forma a apresentar o enunciado da questão, as séries participantes ( $8^{\text {os }}$ e $9^{\text {os }}$ anos, turmas A, B, C, D e E) e o percentual de alunos que responderam afirmativamente aos seguintes tópicos: se leram, escreveram, assistiram ou fizeram parte de peças teatrais. Reiteramos que o questionário solicitava assinalar "sim" ou "não" e, em caso afirmativo, exigia uma complementação à resposta dada. Por esse motivo, trazemos para discussão, também, os excertos que atendem a esse pré-requisito.

Com isso, buscamos observar a concepção que os alunos têm a respeito de nosso objeto de investigação - texto dramático - e, por esse viés, compreender as particularidades que envolvem a escolarização desse gênero discursivo. $\mathrm{O}$ item (a) objetiva conhecer se os alunos participantes desta pesquisa já leram peças teatrais.

\section{a) Aluno-leitor}

Para discussão desse item, selecionamos a Questão 06, que busca realizar uma sondagem em torno da experiência que os alunos têm com a leitura de peças teatrais. $\mathrm{O}$ Gráfico 1, a seguir, apresenta os resultados obtidos com as respostas: 
Gráfico 1 - Resultados da Questão 06 (QA)

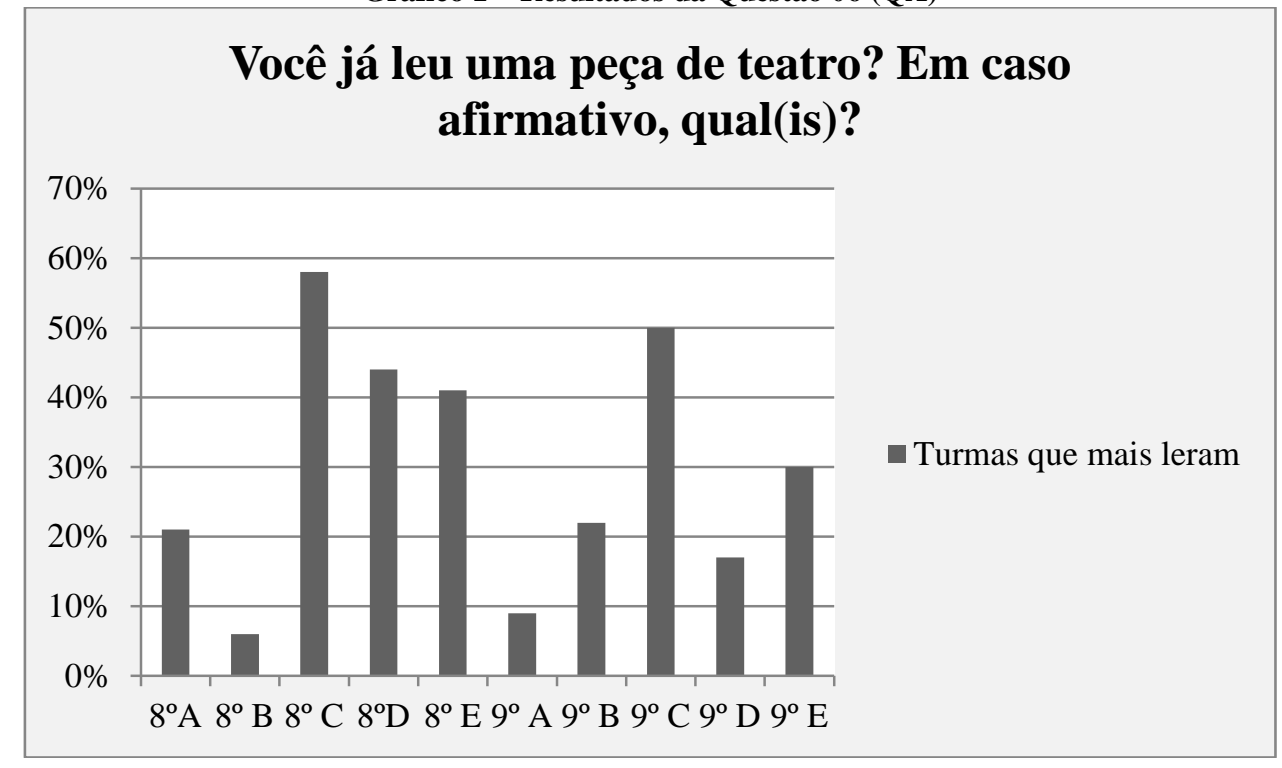

Entre as duas séries que participaram do questionário, constatamos, de início, que os alunos dos $8^{\text {os }}$ anos afirmaram ler mais peças teatrais que os alunos dos $9^{\text {os }}$ anos. A partir da observação do Gráfico 1, é possível verificar, também, que a turma do $8^{\circ}$ ano $\mathrm{C}$, cinquenta e oito por cento (58\%) dos alunos foi a que mais se destacou nesse sentido, seguida da turma do $9^{\circ}$ ano $\mathrm{C}$, cinquenta por cento (50\%). Com exceção dessas duas turmas, os outros resultados apontam para menos da metade de alunos que disseram ter lido peças teatrais. Quanto às turmas que menos leram, temos o $8^{\circ}$ ano $\mathrm{B}$, seis por cento $(6 \%)$, e o $9^{\circ}$ ano $\mathrm{A}$, nove por cento $(9 \%)$.

Da totalidade dos alunos questionados, cento e setenta e sete (177), apenas sessenta e três (63) afirmam ter lido uma peça teatral. Quanto a estes que leram, a maioria diz não se lembrar do título do texto. Os poucos registros que indicam complementação da resposta apontam para exemplares de William Shakespeare e de Maria Clara Machado: QA: 034 - "Na biblioteca da escola tem vários livros teatrais, o que mais gostei foi o livro A bruxinha que era boa”, QA: 062 - "Romeu e Julieta", QA: 110 - "Sonho de uma noite de verão" e QA: 167 "A megera domada". A resposta dada por QA: 034 permite-nos dizer que o acesso a livros de teatro é viabilizado pelo acervo da biblioteca da escola. Observamos, ainda, que os títulos das obras citadas pelos alunos retomam o cânone literário, William Shakespeare, por exemplo, (QA: 062, QA: 110 e QA:167). Esse dado leva-nos a refletir a respeito da versão escolar do texto dramático, pois a seleção do gênero de referência em sala de aula consiste de uma 
escolha muito particular: os clássicos da literatura. Esse dado é corroborado pelo posicionamento dos professores participantes desta pesquisa.

Os resultados da Questão 06 possibilitam-nos afirmar, também, que a leitura de peças teatrais não nos parece uma atividade recorrente nas séries finais do ensino fundamental da escola participante desta pesquisa, pois cento e catorze (114) alunos disseram não ter lido um texto dramático. Isto leva-nos a pensar que esses alunos não tiveram oportunidade de contato com a materialidade linguística do ponto de vista da estrutura desse texto.

É válido mencionar, nesse sentido, o posicionamento de Koch e Elias (2012), para quem a leitura é uma atividade interativa altamente complexa de produção de sentidos, que se realiza com base nos componentes linguísticos presentes na materialidade textual e na sua forma de organização. Segundo as autoras:

$\mathrm{Na}$ concepção interacional (dialógica) da língua, os sujeitos são vistos como atores/construtores sociais, sujeitos ativos que - dialogicamente - se constroem e são construídos no texto, considerando o próprio lugar da interação e da constituição dos interlocutores (KOCH; ELIAS, 2012, p.10-11).

No caso da leitura de um texto dramático, ao assumir a posição aluno-leitor, entendemos que há a possibilidade de os alunos observarem a organização do texto e encontrarem componentes textuais de representatividade, as rubricas, por exemplo, que apontam para os modos como os atores podem falar ou agir - componentes tão importantes para compreensão dos sentidos do texto, em sua relação fala-escrita. Além disso, para leitura, é possível a observação da divisão do texto escrito em cenas, que permite verificar como se constrói o espetáculo e propõe reflexões a respeito dessas duas modalidades da língua.

No próximo item (b), buscamos verificar se os alunos participantes dessa pesquisa tiveram a experiência de escrever uma peça de teatro ou parte dela (cenas). 


\section{b) Aluno-dramaturgo}

Os dados que nos possibilitam discorrer a respeito da posição aluno-dramaturgo, isto é, alunos que, de algum modo, tiveram a oportunidade de escrever peças de teatro (ou cenas), foram apreendidos da Questão 07. Apresentamos, no Gráfico 2, a seguir, os resultados obtidos com as respostas a essa questão:

Gráfico 2 - Resultados da Questão 07 (QA)

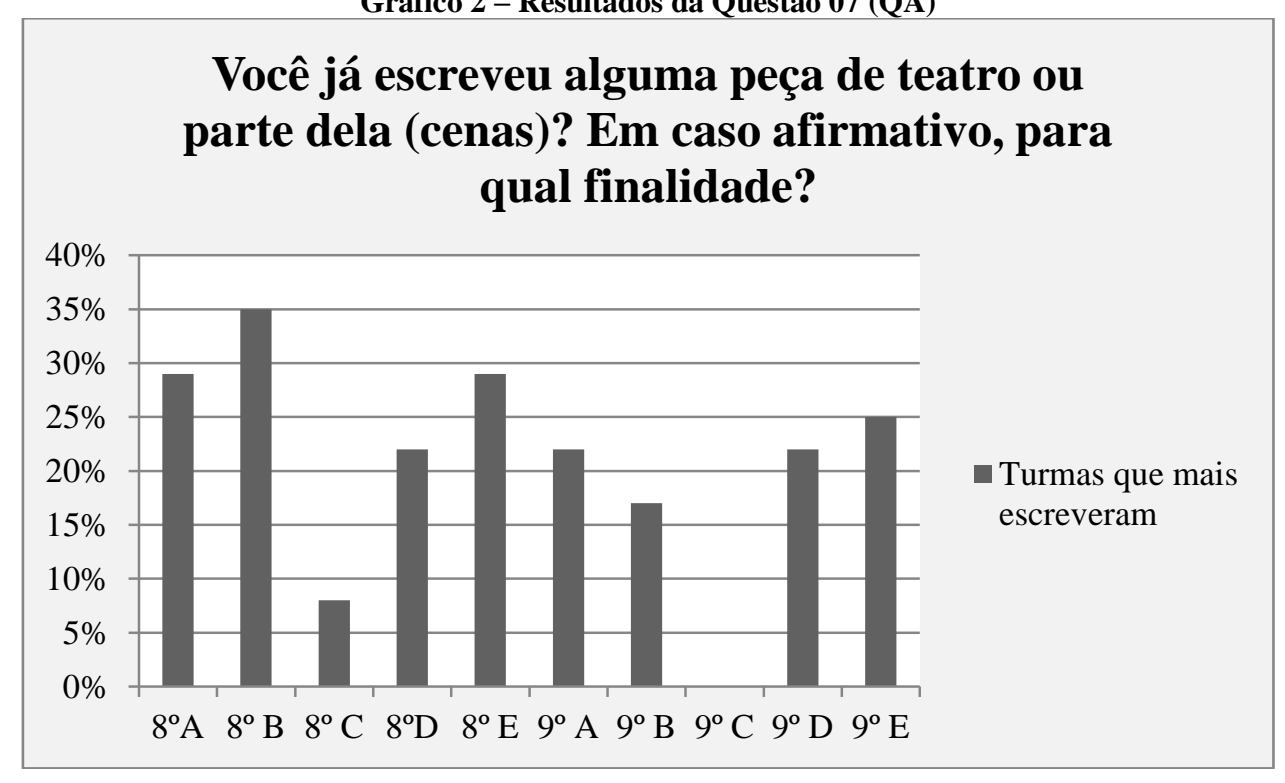

Diante do exposto, é possível observar que, novamente, as turmas do $8^{\circ}$ ano participaram mais de atividade de produção escrita de peças teatrais (como também ocorreu na atividade de leitura) que as turmas do $9^{\circ}$ ano. Verificamos, ainda, percentuais muito baixos em relação à escrita desse gênero, em geral, inferiores a 35\% ( $8^{\circ}$ ano $\left.\mathrm{B}\right)$, chegando a $0 \%\left(9^{\circ}\right.$ ano C).

A maioria dos alunos, cento e trinta e sete (137), afirmou nunca ter escrito uma peça teatral ou parte dela. Para os demais alunos que assinalaram a opção "sim", havia um campo destinado à complementação da resposta, indicando para qual finalidade teria feito a produção textual: "1-Atividade Cultural", "2-Aula de Português", "3-Aula de outra disciplina" e "4Outra(s)". A maioria dos alunos, quinze (15), assinalou a opção 1, "Aula de Português", as demais opções foram assinaladas de modo bastante equilibrado. Quanto à opção 4, não foi 
possível recuperar em qual disciplina os alunos poderiam ter realizado essa atividade, nem tampouco saber quais seriam as outras finalidades atribuídas para essa produção, pois os alunos não complementaram a resposta.

Ainda que um número reduzido de alunos tenha participado da atividade de escrita de uma peça de teatro (ou parte dela), é significativo destacar que essa atividade foi realizada, para a maioria deles, na aula de língua portuguesa. Com isso, podemos entender que, no contexto escolar, escrever peças teatrais relaciona-se, de algum modo, à disciplina Português. E mais: se compararmos os resultados da Questão 06 com a Questão 07, podemos entender, também, que as atividades em torno desse gênero discursivo estão mais associadas à leitura que à escrita.

Passamos discutir a categoria (c) e observar questões voltadas para a possibilidade de os alunos terem assistido a peças teatrais fora ou dentro da escola.

\section{c) Aluno-espectador}

Os dados que comportam essa categoria foram extraídos das Questões 01 e 02. Por meio da primeira questão, buscamos identificar se os alunos já haviam assistido a peças teatrais fora do contexto escolar, em um teatro da cidade, por exemplo; na segunda questão, procuramos observar se os alunos tiveram essa experiência dentro da escola. Os resultados obtidos com a Questão 01 estão dispostos no Gráfico 3, a seguir: 
Gráfico 3 - Resultados da Questão 01 (QA)

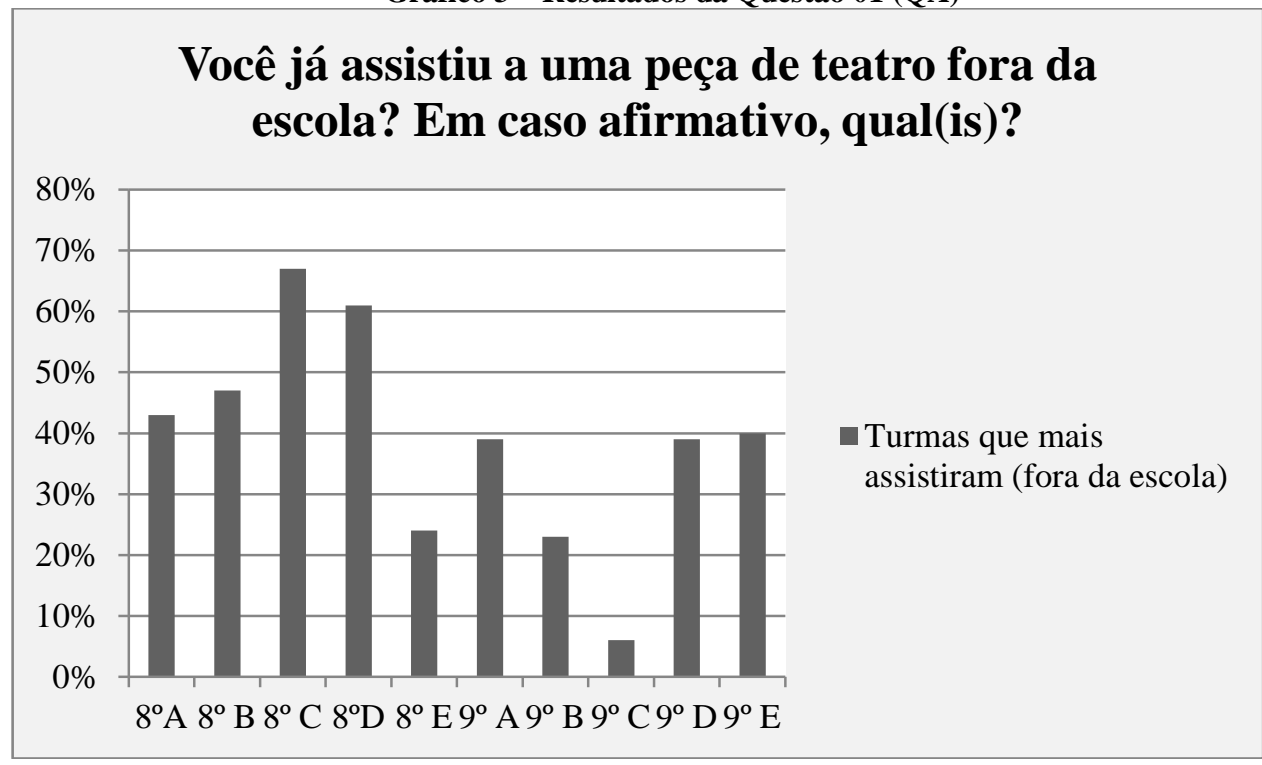

Os resultados das turmas dos $8^{\text {os }}$ e $9^{\text {os }}$ anos parecem mais equilibrados, se comparamos as práticas de produção de leitura e escrita de peças teatrais à prática de assistir a peças de teatro fora do contexto escolar. Ainda assim, destacamos a turma do $9^{\circ} \mathrm{C}$, pois que, dos dezesseis (16) alunos presentes no dia da aplicação do questionário, apenas um (01) afirmou ter tido essa experiência. As turmas do $8^{\circ}$ ano $\mathrm{E}$ e $9^{\circ}$ ano $\mathrm{B}$ também apresentaram percentuais baixos, vinte e quatro por cento (24\%) e vinte e três por cento (23\%), respectivamente.

Da totalidade dos alunos participantes da pesquisa, a maioria, cento e quatorze (114), assinalou não ter assistido a peças de teatro fora do contexto escolar. Dentre aqueles que assinalaram a opção "sim", muitos disseram não se lembrar do nome da peça e alguns disseram ter assistido, não especificando o título, por exemplo: QA: 073 "Uma peça de atores da globo o nome da peça não lembro".

É significativo destacar o fato de que alguns alunos registraram o nome do teatro da cidade, retomando em suas respostas não o título da peça teatral, mas o espaço físico (a casa de espetáculos) em que ocorreu a apresentação: QA: 074 - "No teatro Calil Haddad", QA: 079 - "No Calil Haddad de Maringá", QA - 139 - "Uma peça de comédia no Teatro Marista" e QA: 163 - "Eu já vi um teatro no Calil Haddad só que não me lembro da peça porque já faz anos que eu vi”. Esclarecemos que, em Maringá-PR, os Teatros Calil Haddad e Marista são os maiores da cidade, com capacidade para 759 e 911 lugares, respectivamente. 
No campo destinado à complementação da resposta, alguns alunos recuperaram a tipologia das peças a que assistiram (circo, dança, musical), conforme comprovam os exemplos: QA: 121 - “Já fui em circo", QA: 131 - "Uma peça de balé”, QA: 154 - "Um teatro musical". E poucos retomaram o título da peça: QA: 016 - "Peter Pan”, QA: 025 "João e o pé de feijão", QA: 045 - "Alice no país das maravilhas", QA: 057 - "Mágico de Oz”, QA: 094 - “A bela e a fera, chapeuzinho vermelho", QA: 103 - "Hermanoteu (Os melhores do mundo)", QA: 132 - "A árvore dos mamulengos" e QA: 149 - "O menino que ganhou uma boneca".

Podemos observar esses dados do ponto de vista do teatro como um bem cultural. Sob essa perspectiva, ir ao teatro configura-se uma possibilidade de acesso a uma arte milenar, repleta de histórias de glórias e fracassos, múltiplas linguagens e mistérios, conforme destacou Peixoto (1986, p.7),

O teatro inúmeras vezes parece uma expressão em crise. Em certas épocas quase perde o sentido. Em outras é perseguido. Às vezes refugia-se em pequenas salas escuras, às vezes sai para as ruas e redescobre a luz do sol. Sua função social tem sido constantemente redefinida. Desde muitos séculos antes de nossa era até hoje, nunca deixou de existir: há algum impulso no homem, desde seus primórdios, que necessita deste instrumento de diversão e conhecimento, prazer e denúncia. (grifo nosso)

Ir ao teatro constitui-se, ainda, uma ação cultural, conforme salienta Teixeira (2001). Para o autor, o teatro reúne em si todos ou a maioria dos elementos vitais à ação cultural, entendida como a criação de oportunidades para o uso dos recursos pessoais em seu potencial mais amplo como modo de expressão e intelecção do mundo. Assim,

O teatro ainda vive mergulhado no sonho, ou ambição, de ser a arte total por excelência - e tem ampla razão nisso. Tudo pode ser conjugado em cena: dança, música, imagem em movimento ou estática, e também, numa outra esfera, o indivíduo e o grupo, o indivíduo no grupo (TEIXEIRA, 2001, p.8889).

$\mathrm{Na}$ sociedade contemporânea, essa prática multissemiótica convive com outras práticas, como o cinema e a televisão. Enquanto essas instituem-se produtos concebidos e 
difundidos em larga escala industrial, o teatro ainda depende do confronto vivo entre atores e espectadores, da execução artesanal de cada peça, não podendo ser reproduzido ou replicado como um filme ou um programa de TV. Corrobora essa afirmação, o posicionamento de Rosenfeld (1993, p.245), para quem:

As indústrias culturais, sobretudo a televisão e o cinema, naturalmente são uma concorrência poderosa, favorecida pelo fato de no Brasil, antes da expansão desse meios e artes, não se ter constituído um amplo público habituado a frequentar teatros e por isso mesmo capaz de transmitir esse hábito em larga medida às próximas gerações.

Nessa direção, destacamos o papel da escola como agente cultural, no sentido de fomentar atividades que propiciem aos alunos o diálogo com as várias formas de manifestação artística, a dança, a música, o grafite e, também, o teatro. Entendemos, assim, que o encontro entre palco e plateia pode ser mediado pela escola, seja pela divulgação dos espetáculos em cartaz na cidade ou pela sensibilização para o teatro no próprio espaço escolar.

Para dar continuidade a essa reflexão, selecionamos a Questão 02 que busca observar se os alunos participantes desta pesquisa assistiram a peças teatrais nas dependências da escola. Os resultados apresentam-se registrados no Gráfico 4, a seguir:

Gráfico 4 - Resultados da Questão 02 (QA)

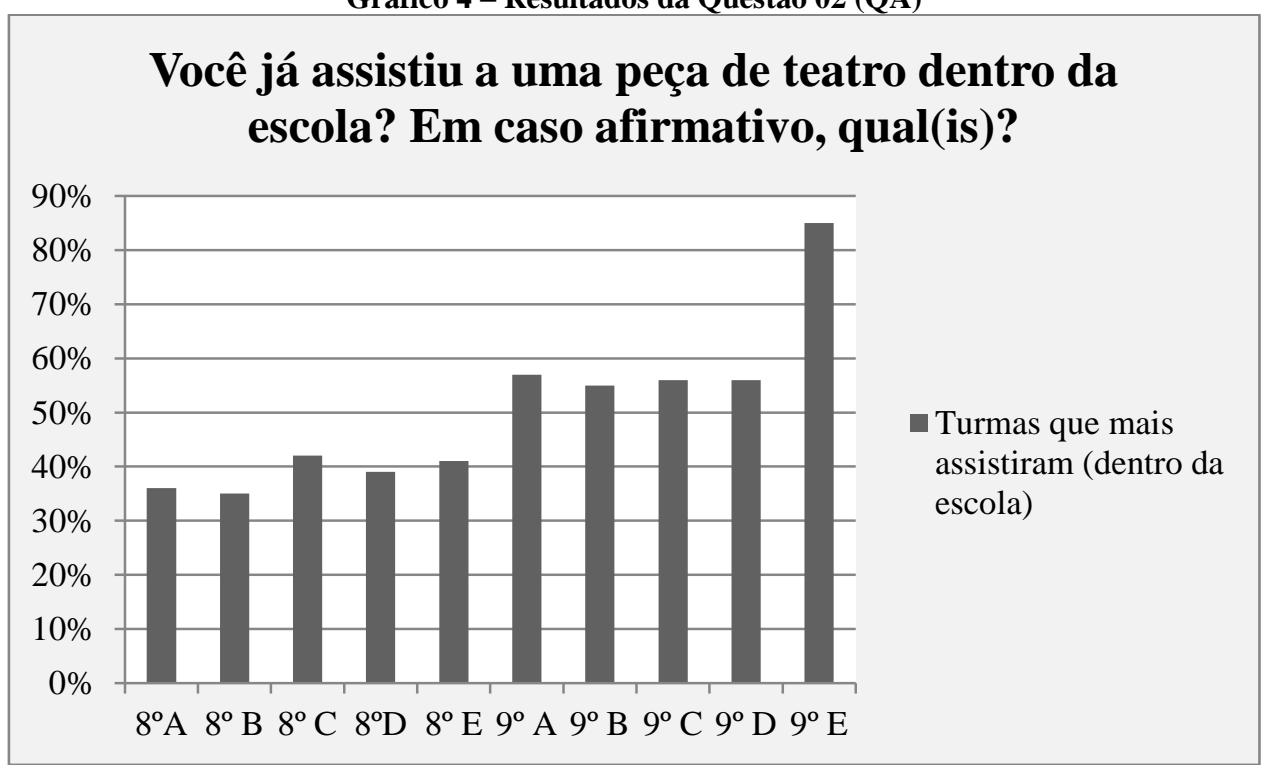


Os dados do Gráfico 4 revelam que a experiência em assistir peças teatrais dentro do espaço escolar é mais expressiva para os alunos dos $9^{\text {os }}$ anos. Com relação à totalidade dos alunos, oitenta e seis (86) disseram ter assistido e noventa e um (91) disseram não ter assistido. Esses resultados nos parecem bastante equilibrados para uma mesma escola em séries tão próximas. Podemos interpretar esses dados de duas maneiras: i) as apresentações teatrais no espaço escolar podem não ser realizadas para todos os alunos da escola ou ii) as apresentações teatrais podem ser realizadas em turnos distintos (manhã ou tarde), não atendendo, assim, todas as turmas da escola.

A maioria dos alunos que respondeu ter assistido a peças teatrais dentro da escola afirmou não se lembrar do nome do espetáculo. Outros, porém, indicaram algumas datas comemorativas que, de algum modo, recuperam a apresentação teatral que assistiram, conforme apontam os exemplos: QA: 041 - "Foi na festa junina", QA: 061 - "Da Páscoa", QA: 178 - "Teatro do dia das mães e dos pais, teatro da consciência negra e do Natal". Alguns alunos optaram, ainda, por registrar os temas abordados, são eles, QA: 057 - "Teatro religioso", QA: 095 - "Bullying”, QA: 111 - "Feira Cultural”, QA: 119 - "Educação Fiscal”, QA: 129 - "A maioria é quando os dentistas vem aqui e fazem um teatro explicando sobre os dentes", QA: 133 - "Sobre a cultura da África", QA: 139 - "Violência infantil”, QA: 147 "Sobre a dengue".

É possível afirmar, nesse sentido, que as peças teatrais apresentadas no Colégio Estadual Rodrigues Alves têm por foco datas comemorativas (Páscoa, Natal, Festa Junina, Dia dos Pais, das Mães, Dia da Consciência Negra) ou assuntos que envolvem sociedade, cultura, saúde e educação, por exemplo. Esse dado é significativo para pensarmos na versão escolar do texto dramático e, mais amplamente, na presença do teatro no contexto educacional, tendo em vista que ele se faz recorrente para atender determinadas finalidades escolares.

Dito de outro modo - e para compreender a versão escolarizada do texto dramático -, essa prática discursiva (apresentação teatral) parece estar relacionada a práticas escolares que buscam a socialização entre pais, alunos, professores e direção, e que podem ser viabilizadas, também, no formato de atividades que oportunizam atender ao calendário letivo (ênfase nas datas festivas, especialmente). Ou, ainda, tais práticas podem ser empregadas como meios de divulgação e circulação dos saberes multi ou transdisciplinares e, nestes casos, o teatro revelase meio pedagógico (multissemiótico) para discussão de temas socialmente relevantes. 
Outras possibilidades são explicitadas nos exemplos: QA: 029 - "Do teatro que acontecia na escola aos sábados", QA: 030 - "Quando os professores formam um grupo de teatro e depois apresentam na hora do recreio", QA: 040 - "Na verdade eu fazia teatro aqui no colégio". Esses dados parecem revelar a presença do teatro em atividades extracurriculares oferecidas, geralmente, no contraturno escolar.

A retomada dos dados até aqui apresentados permite-nos dizer que as possibilidades de recepção do gênero texto dramático fora ou dentro do espaço escolar do Colégio Estadual Rodrigues Alves não envolveu os alunos de maneira significativa, pois a maioria afirma não ter assistido ou, se assistiu, afirma não se lembrar do nome da peça teatral.

Cabe destacar o posicionamento da pesquisadora portuguesa Zurbach (1999), a respeito do ensino do texto dramático nas aulas de língua e literatura. Ao resgatar a historicidade do teatro na educação, a autora observa o reconhecimento de uma renovação na percepção e no conhecimento do texto de teatro: a necessidade da ida ao teatro, da possibilidade do aluno-espectador. Para a autora,

\begin{abstract}
Na mesma apetência e abertura no sentido duma restituição ao teatro do seu modo específico de se realizar na sociedade, isto é, a sua dimensão objecto artístico, a cultura escolar do teatro, até então alimentada pela 'leitura sentada' dos autores e dos textos consagrados no programa oficial, clássicos ou contemporâneos, foi levada a colher fora das paredes convencionais e institucionais da sua existência no mundo - a escola -, um outro conhecimento do teatro, o do espetáculo enquanto obra artística plena, a conviver com obras de autores estrangeiros, a celebrar a universalidade do teatro nas salas do teatro vivo (ZURBACH, 1999, p.55).
\end{abstract}

No Brasil, Desgrandes (2009) discorre a respeito da pedagogia (ou formação) do espectador, tendo em vista a possibilidade de um duplo acesso do aluno ao teatro; segundo esse estudioso, não basta disponibilizar a ida à casa de espetáculos ou oportunizar o acesso ao teatro na escola, é preciso incitar o diálogo com a obra artística e o desejo pela experiência teatral. No termos do autor, propiciar aos alunos a compreensão do espetáculo não se reduz à discussão da trama, "mas se constitui de uma totalidade de signos, pois se possibilita a percepção da especificidade da arte teatral e a elaboração dos elementos semióticos presentes na encenação" (DESGRANDES, 2009, p.93). 
Nessa direção, a pesquisa de Rosseto (2008) em torno da recepção no ensino do teatro parece contribuir para o entendimento da versão escolar do texto dramático, sob a ótica do aluno-espectador. Para o autor, são raras as oportunidades dos alunos de apreciarem teatro quer isto envolva a ida a um teatro propriamente dito, quer se refira a apresentações no espaço escolar. Em ambas as alternativas, o autor constatou, por meio de entrevista com docentes de Arte do estado do Paraná, que a prontidão do aluno para a recepção do espetáculo teatral não é trabalhada, nem tampouco é discutida a experiência como espectador, após o espetáculo. Consequentemente, a reflexão de procedimentos que envolvem a montagem espetacular ou os níveis de compreensão e percepção sensoriais, estéticos, históricos aparece nas escolas "como atividade de menor importância" (ROSSETO, 2008, p.78).

A última categoria (d) a ser observada apresenta dados correspondentes às possibilidades de os alunos terem participado da produção de um teatro na escola.

d) Aluno-ator

Apresentamos a Questão 03 que buscou investigar a participação dos alunos em atividades teatrais nas disciplinas escolares. O Gráfico 5, a seguir, aponta os resultados:

Gráfico 5 - Resultados da Questão 03 (QA)

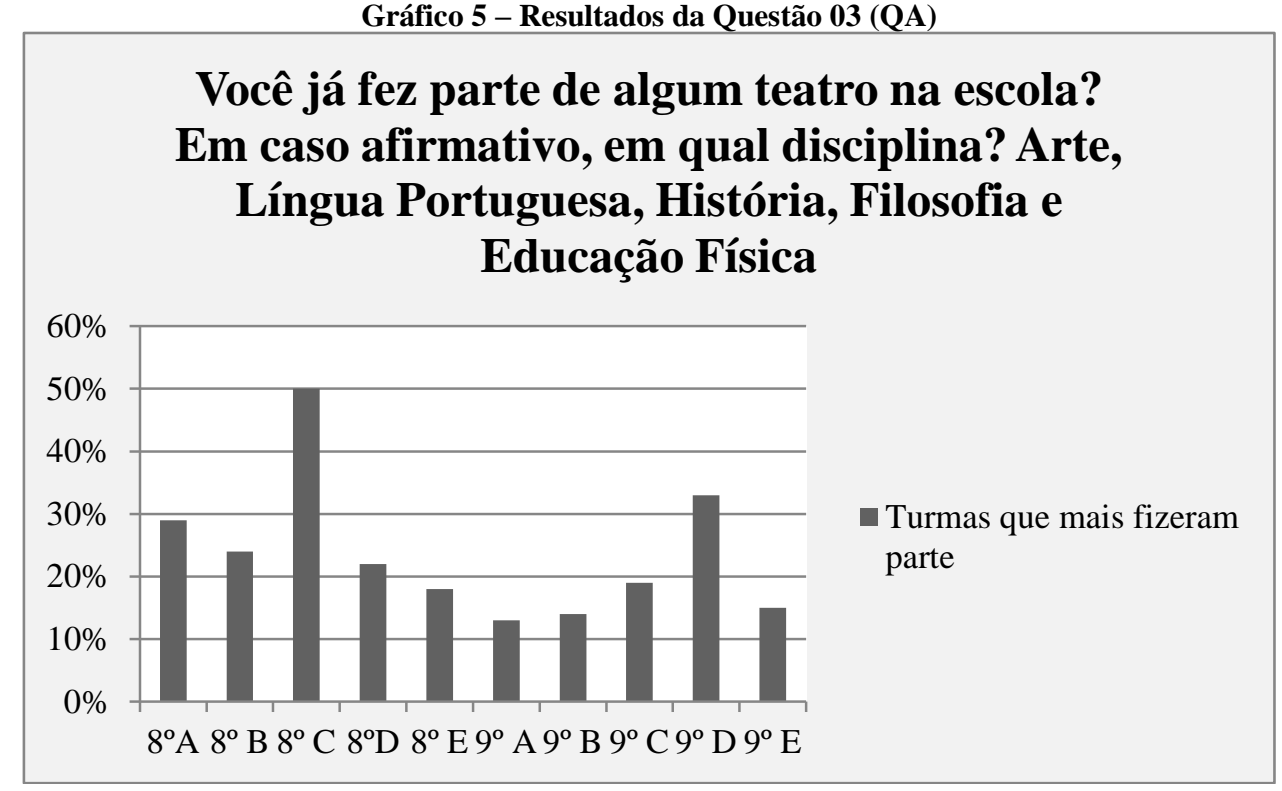


A recepção de peças teatrais já havia sido assinalada por percentuais baixos, se levarmos em conta a totalidade dos alunos que responderam ao questionário. Os dados apresentados no Gráfico 5 apontam para percentuais ainda menores, como é o caso, por exemplo, dos alunos do $9^{\circ}$ ano $\mathrm{A}$ - somente treze por cento $(13 \%)$ disseram ter participado de peças teatrais.

Da totalidade dos alunos questionados, cento e setenta e sete (177), apenas trinta e nove (39) revelaram ter passado pela experiência de participar de algum teatro no contexto escolar. Com relação às disciplinas mencionadas como complementação da resposta, Arte foi assinalada como primeira opção, para catorze (14) alunos, na sequência, Educação Física, para sete (7) alunos e, por fim, Língua Portuguesa, para cinco (5) alunos.

A leitura desses resultados - em comparação aos resultados apontados nas categorias (a), aluno-leitor, e (b), aluno-dramaturgo, - possibilita-nos afirmar que, em relação às disciplinas escolares, a produção oral (representação) do texto dramático parece associar-se às atividades propiciadas pelas disciplinas Arte e Educação Física; já à disciplina Língua Portuguesa seriam atribuídas atividades de leitura e escrita de peças teatrais. Salientamos que os dados apreendidos deste grupo escolar sinalizam, por um lado, a rara participação dos alunos na produção/recepção do texto dramático no contexto escolar e, por outro, a escassa oferta de atividades como essas nas disciplinas escolares.

A despeito de serem reduzidas as oportunidades e participações de alunos nas atividades das disciplinas, quando ocorre, pode-se observar o que indica Iturbe (2007), ao asseverar que:

O centro da dramatização se relaciona basicamente com as matérias de Língua, Artes, Música e Educação Física (psicomotricidade), sempre mantendo como fundo a recordação das matérias transversais. Aspectos tais como a expressão oral em todas as suas dimensões (vocalização, dicção, tom, entonação, riqueza expressiva, modulação), expressão escrita, estabelecimento de diálogos (ortografia, especialmente pontuação), descrição de cenários, movimentos e personagens concentram os esforços da disciplina de Língua, fazendo dela uma matéria essencial para o desenvolvimento da arte, da comunicação e da informação (ITURBE, 2007, p.9-10).

Em relação aos resultados apreendidos, é possível afirmar que texto e performance aparecem dissociadas nas disciplinas escolares. A versão do texto dramático evocada pela 
experiência dos alunos participantes desta pesquisa revela-nos: i) a rara participação dos alunos em montagens teatrais e da vivência da posição aluno-ator e ii) a não associação dessa prática discursiva (representação) à disciplina Língua Portuguesa.

Os dados obtidos com essa questão possibilitam-nos afirmar, ainda, que poucos alunos do Colégio Estadual Rodrigues Alves tiveram a oportunidade de desenvolver atividades que envolvem a produção de um espetáculo teatral: atuar, produzir cenário, confeccionar figurinos/acessórios cênicos, divulgar a peça, executar os efeitos sonoros etc.

Diante do conjunto de dados apresentados ao longo desse capítulo, julgamos necessário proceder a uma síntese dos resultados apreendidos até então, tarefa que nos propomos realizar a seguir.

\subsection{Resultados das análises}

Acreditamos que o construto teórico bakhtiniano em torno do gênero discursivo como prática histórica e socialmente situada ajuda-nos a compreender o conjunto de dados apresentados. Para Bakhtin (2003[1979]), todo e qualquer gênero circula em determinada esfera e cada esfera determina os modos de circulação desse gênero.

Nesse sentido, tanto a análise das unidades didáticas quanto a observação das propostas em torno do texto dramático, discutidas no capítulo III, permitiu-nos refletir a respeito da concepção desse gênero discursivo: o texto dramático pode oscilar entre a esfera literária ou a artística/teatral. Além disso, o conjunto de dados dos questionários e as pesquisas que promovem um diálogo entre arte e educação, mencionadas ao longo deste capítulo, autoriza-nos a dizer, também, que o teatro circula na esfera escolar. Faz-se necessário pontuar que se trata de uma amostragem do ensino de parte do estado do Paraná, que pode ser representativo do que ocorre em espaços de ensino no país, mas que não se pode generalizar, sendo necessária a expansão da pesquisa empírica para serem auferidos os resultados.

Quanto aos resultados evocados pelos discursos dos professores de língua portuguesa, temos que: 
I. O texto dramático possibilita o trabalho com a oralidade, sobretudo, em atividades de encenação e leitura dramática.

II. O teatro permite a socialização do grupo escolar, a produção oral de um texto literário e a fixação de conteúdos.

III. A produção oral do texto dramático possibilita o desenvolvimento da competência expressiva.

IV. Os materiais utilizados como referência para produção de leitura, escrita e oralidade são oriundos de diversas fontes: autores da literatura brasileira, dramaturgos clássicos, livros didáticos e produção dos alunos.

E quanto aos alunos:

V. Ler um texto dramático é prática mais comum que escrever. Em ambos os casos, a disciplina Língua Portuguesa é aponta para tal.

VI. A oportunidade de ser espectador de peças teatrais é maior que a de participar da montagem de um espetáculo teatral. Neste último caso, a ocorrência dá-se nas disciplinas Arte e Educação Física.

VII. A circulação do gênero no espaço escolar realiza-se em torno de datas festivas, como meio de divulgação de temas socialmente relevantes ou em atividades de contraturno.

Destacamos, ainda, o fato de que o posicionamento de alguns professores podem apontam para a percepção do caráter multimodal do texto dramático. Ao eleger a produção oral como gênero potencial para o ensino da oralidade, os professores de língua portuguesa revelaram outras semioses aí envolvidas, a entonação, expressão facial, por exemplo.

As análises efetuadas suscitaram alguns questionamentos em torno da escolarização do texto dramático no que diz respeito ao: 
a) Objeto de ensino de língua portuguesa:

i. Quais atividades priorizar? Leitura silenciosa ou dramática, adaptação de textos literários ou produção autoral? Encenação?

ii. Quais competências desenvolver? Expressiva, somente?

iii. Quais saberes estão engendrados? Escritural, oral ou multimodal?

b) À prática de linguagem:

i. Quais são as competências decorrentes das atividades relacionadas ao fazer teatral: ler, escrever, assistir e dramatizar?

Entendemos que a formulação e a aplicação de uma sequência didática em torno do texto dramático possa nos ajudar a refletir com maior propriedade sobre esses questionamentos. Trata-se do terceiro conjunto de dados que constitui este trabalho, descrito no próximo capítulo. 


\section{CAPÍTULO V}

\section{Pesquisa-ação: proposta de sequência didática em torno do gênero discursivo texto dramático}

Sua última apresentação é a primeira da plateia.

Viola Spolin

Nos capítulos anteriores, empreendemos uma investigação voltada às percepções do ensino do texto dramático; para tanto, utilizamos duas técnicas de geração de dados: a análise documental e a aplicação de questionários. Os resultados decorrentes da observação desse conjunto de dados possibilitaram-nos descrever a problemática da escolarização desse gênero discursivo, o que nos levou a compreender a concepção de texto dramático evocada pelos materiais consultados (livros didáticos) e pelos sujeitos participantes desta pesquisa (professores e alunos). Ainda que envolvam apenas recorte do que pode ocorrer em contextos de ensino e aprendizagem no país, as reflexões arroladas nos capítulos III e IV configuram-se importantes para o entendimento do que vem a ser o texto dramático na escola.

À luz do que precede, conduzimos, neste capítulo, uma pesquisa-ação para solidificar a discussão dos processos que envolvem, especificamente, as práticas de ensinar/aprender texto dramático na aula de língua portuguesa. Para tanto, buscamos respaldo teórico em estudos voltados a esse método de investigação (pesquisa-ação), dos quais destacamos Thiollent (2005[1985]) e Franco (2005). 


\subsection{Pesquisa-ação: aportes teórico-metodológicos}

A pesquisa-ação constitui um método de pesquisa social com base empírica, voltada para a descrição de situações concretas e a para intervenção (ou ação orientada) com vistas à resolução de problemas efetivamente detectados em coletividades consideradas. Essa estratégia de pesquisa prevê uma ação planejada e pressupõe a interação entre pesquisadores e sujeitos da situação investigada; trata-se de uma forma de experimentação em situação real, na qual o pesquisador intervém conscientemente, de forma a se constituir pesquisador participante (THIOLLENT, 2005[1985]).

Conforme salienta o autor, no contexto educacional, essa orientação metodológica possibilita a compreensão de práticas e a produção de conhecimento de uso mais efetivo, contribuindo para o esclarecimento de microssituações escolares e para a definição de objetivos de ação pedagógica e de transformações mais abrangentes.

A esse respeito, Franco (2005) assevera que pesquisa e ação podem caminhar juntas em vistas à transformação de práticas escolares. Para tanto, faz-se necessária a associação da pesquisa a uma estratégia de intervenção, indicando a posição de pesquisa inicialmente como ação de intervenção; ação essa que, imediatamente, passa a ser objeto de pesquisa. Segundo a autora, a pesquisa-ação sugere a interdependência entre pesquisa e ação, ação e pesquisa, “considerando-se até que deveria ser expressa em forma de dupla flecha, ao invés de hífen: pesquisa $\leftrightarrow$ ação, de modo a caracterizar a concomitância, a intercomunicação e a interfecundidade" (FRANCO, 2005, p.496).

Esse método de pesquisa permite reconstruções e reestruturação em todo seu desenrolar, caracteriza-se como procedimento essencialmente pedagógico que promove o desenvolvimento de referências contínuas e evolutivas com o coletivo, isto é, favorece a apreensão de significados construídos e em construção. De acordo com Franco (2005), tratase de um método que instaura uma dinâmica de princípios e práticas dialógicas, participativas e transformadoras.

A ordem de prioridade dos problemas a serem encaminhados sob forma de ação concreta resulta da participação efetiva de pesquisador e sujeitos investigados. Assim, tem-se o ponto de partida e o ponto de chegada e, no intervalo entre as duas extremidades, há 
múltiplos caminhos a serem escolhidos em função das circunstâncias; desse modo, o procedimento metodológico da pesquisa-ação é flexível e permite ajustes progressivos (FRANCO, 2005).

Para Rojo (1997), na pesquisa-ação, a ação é comunicativa e, antes de tudo, interativa, já que se constrói na coletividade; não é individualista, não persegue o êxito, mas, ao contrário, é dialógica,

[...] nasce no seio da situação que interpreta e oferece saída para sua problemática. É comunitária. Antes da eficiência e do sucesso busca o entendimento e o acordo. Consensual. É axiológica porque acredita na validade das normas discutidas. Aberta a todos, receptora do novo e do diferente. "Mansa na escuta e forte na tomada de decisões ${ }^{41 "}$ (ROJO, 1997, p. $32-33)$.

Diante do exposto, entendemos que a pesquisa-ação coaduna-se à proposta de elaboração e aplicação de uma sequência didática, tal como postulam os pesquisadores do Grupo da Universidade de Genebra - conjunto de atividades escolares organizadas, de maneira sistemática, em torno de um gênero discursivo oral ou escrito -, tomando-o em uma perspectiva "construtivista, interacionista e social que supõe a realização de atividades intencionais, estruturadas e intensivas que devem adaptar-se às necessidades particulares dos diferentes grupos de aprendizes" (DOLZ; NOVERRAZ; SCHNEUWLY, 2004, p.93).

Nesse sentido, a escolha desse método de investigação (pesquisa-ação) e da sequência didática como procedimento norteador do trabalho com gêneros discursivos justifica-se pelo fato de se querer conhecer, empiricamente, a dinâmica do ensino e da aprendizagem do texto dramático na aula de língua portuguesa, considerando, para tanto, a:

- Identificação de um problema (o texto dramático como objeto de ensino - multimodal - de língua portuguesa).

- Aplicação de um procedimento, de uma ação pedagógica (sequência didática).

\footnotetext{
${ }^{41}$ Tradução nossa de: "[...] nace en el seno de la situación a la que interpreta y ofrece salida a su problemática. Antes que la eficacia y el éxito busca el entendimiento y el acuerdo. Consensúa. Es axiológica porque cree en la valía de las normas discutidas. Abierta a todos, receptora de lo nuevo y diferente. 'Mansa en la escucha y fuerte en la toma de decisiones"”.
} 
- Flexibilidade e adaptação na proposição de atividades.

- Experimentação de práticas de linguagem que envolva a produção e a recepção do texto dramático.

- Participação efetiva da pesquisadora e dos sujeitos da situação investigada (alunos) e descrição de suas ações concretas.

- Transformação de práticas escolares, ao assumir, nesta pesquisa: i) a dupla acepção de texto dramático (UBERSFELD, 2010) e ii) a reciprocidade existente entre texto dramático e representação cênica (CALZAVARA, 2009).

Embasados teoricamente quanto ao método a ser utilizado nesta pesquisa, procedemos, a seguir, à apresentação dos sujeitos participantes, tendo em vista essas considerações.

\subsection{Sujeitos participantes da pesquisa-ação}

O critério para seleção da série/turma participante da pesquisa-ação decorreu, primeiramente, da observação dos resultados da aplicação dos questionários aos alunos dos $8^{\text {os }}$ e $9^{\text {os }}$ anos do Colégio Estadual Rodrigues Alves, de Maringá-PR. Conforme consta na Tabela 8 (p.155), o $8^{\circ}$ ano E apresentou maior adesão, isto é, oitenta e nove por cento (89\%) dos alunos responderam ao questionário - dos dezenove (19) alunos matriculados, dezessete (17) estavam presentes no dia da aplicação. Outro critério deveu-se à concordância da coordenação pedagógica e da professora de língua portuguesa, quanto aos ajustes do cronograma de realização das atividades às datas e aos horários das aulas da referida série/turma. Selecionada a turma, o passo seguinte consistiu de assegurar o consentimento informado $^{42}$ dos sujeitos da pesquisa.

Para auxiliar na contextualização dos participantes da pesquisa, retomamos, brevemente, o que foi apreendido da entrevista com a coordenadora pedagógica do Colégio Estadual Rodrigues Alves ${ }^{43}$ : trata-se de uma instituição, localizada na periferia de Maringá; uma das escolas públicas mais antigas da cidade que atende o maior número de alunos. Em

\footnotetext{
${ }^{42}$ Cf. Anexo V.

${ }^{43}$ A entrevista também é mencionada no capítulo IV (p.130).
} 
relação à turma participante da pesquisa, temos que o $8^{\circ}$ ano $\mathrm{E}$ constitui-se de dezessete (17) alunos, seis (06) meninos e onze (11) meninas, com faixa etária entre 12 e 15 anos.

A pesquisa-ação ocorreu no período de junho a dezembro de 2013, em que se registraram vinte e três (23) encontros, totalizando trinta horas-aula (30h/a). Consideramos necessário indicar que, no desenvolvimento da sequência didática, nem todos os alunos puderam participar do conjunto de atividades propostas; assim, no período da intervenção houve: faltas, entrada de novos alunos e saída de outros, por vários motivos, mudança de turno, escola e/ou cidade ${ }^{44}$.

Os dados que faremos observar neste capítulo provêm do resultado de atividades desenvolvidas para apreensão do gênero texto dramático e de anotações pessoais em torno de observações/reflexões realizadas in loco, com base na verbalização e na ação dos alunos.

Na próxima seção, apresentamos uma síntese da sequência didática aplicada junto aos alunos do $8^{\circ}$ ano $\mathrm{E}$.

\subsection{Síntese da sequência didática aplicada}

A pesquisa-ação que aqui se apresenta fundamenta-se na contribuição teóricometodológica do Grupo da Universidade de Genebra, Schneuwly e Dolz et alii (2004), no que diz respeito à seleção do procedimento sequência didática, e na proposta modular para apreensão de gêneros discursivos de Lopes-Rossi, em seus trabalhos de 2002a, 2006, 2011 e 2012. Ressaltamos que nossa sugestão, apresentada no capítulo I deste trabalho, compreende cinco (05) módulos didáticos: 1. Presentificação do Objeto de Ensino, 2. Produção de Leitura, 3. Produção Escrita, 4. Produção Oral e Multimodal e 5. Circulação.

Com intuito de desenvolver a competência genérica dos alunos, por meio de experiências socioculturais que envolvam as práticas de linguagem de produção/recepção do gênero discursivo texto dramático, a sequência didática aplicada aos alunos do $8^{\circ}$ ano $\mathrm{E}$ buscou promover o seguinte percurso:

\footnotetext{
${ }^{44}$ A lista de presença dos alunos, disponível no Anexo VI deste trabalho, pode confirmar esse dado.
} 
1. Assistir a uma peça de teatro.

2. Ler a peça de teatro a que assistiu.

3. Escrever o próprio texto dramático.

4. Encenar o texto que escreveu.

Tendo em vista o último item, a intervenção didática procurou propiciar, também, a contextualização dos alunos no processo da montagem do texto dramático que escreveram, no qual se destacaram algumas atividades: confecção de cenário, organização de figurinos, seleção de sonoplastia, realização de leituras dramáticas, memorização das falas, marcações das cenas, criação de personagens, produção de cartazes de divulgação da peça e elaboração do programa a ser entregue para o público no dia da apresentação.

Com a apresentação desta proposta, defendemos a ideia de que o professor, ao trabalhar com o gênero discursivo texto dramático como objeto de ensino de língua portuguesa, considere a possibilidade de conduzir os alunos a uma vivência dramatúrgica completa, fazendo-os assumir/experimentar os papéis de plateia, leitor, autor, ator, sonoplasta, produtor.

Em razão disso, o direcionamento de nossa ação pedagógica para apreensão do gênero discursivo texto dramático apresenta-se diferente da concepção evocada pelos livros didáticos $^{45}$, evidenciadas também pelas respostas aos questionários ${ }^{46}$. O eixo norteador da sequência didática aplicada aos alunos do $8^{\circ}$ ano E baseia-se na relação de reciprocidade existente entre texto dramático escrito e texto dramático oralizado/representado e, consequentemente, no uso e na adequação das multimodalidades solicitadas em cada uma dessas práticas de linguagem e dos saberes engendrados na esfera teatral.

A proposta, assim explicitada, prevê que os alunos participantes desta pesquisa-ação sejam levados a desenvolver habilidades linguístico-discursivas, comunicativas, interativas e expressivas, exercendo-as ao escreverem, de modo coletivo e reflexivo, o texto dramático que irão encenar.

\footnotetext{
${ }^{45}$ Cf. Capítulo III (p.122).

${ }^{46}$ Cf. Capítulo IV (p.168)
} 
É válido pontuar que não se constitui escopo deste trabalho encontrar um estatuto genérico único para o texto dramático (escrito e oralizado/representado); nossa discussão recobre o tratamento que desejamos dar a essas práticas quando se encontram como objeto de ensino de língua materna (quando o gênero é escolarizado) a partir de direcionamentos para a produção/recepção desse gênero. Entendemos, desse modo, como assinalam Dolz, Noverraz e Schneuwly (2004, p.108), que as sequências didáticas podem funcionar como elementos norteadores à disposição dos professores e só "assumirão seu papel pleno se os conduzirem, através da formação inicial ou contínua, a elaborar; por conta própria, outras sequências".

No Quadro 6, a seguir, apresentamos a síntese da sequência didática desenvolvida nesta pesquisa-ação, em que podemos observar: os cinco (05) módulos didáticos que singularizam a aplicação desse procedimento, a referência às aulas e respectivas datas de aplicação, a quantidade de horas-aula dispensadas em cada encontro e, por fim, a descrição das atividades desenvolvidas junto aos alunos.

Quadro 6 - Síntese da sequência didática aplicada

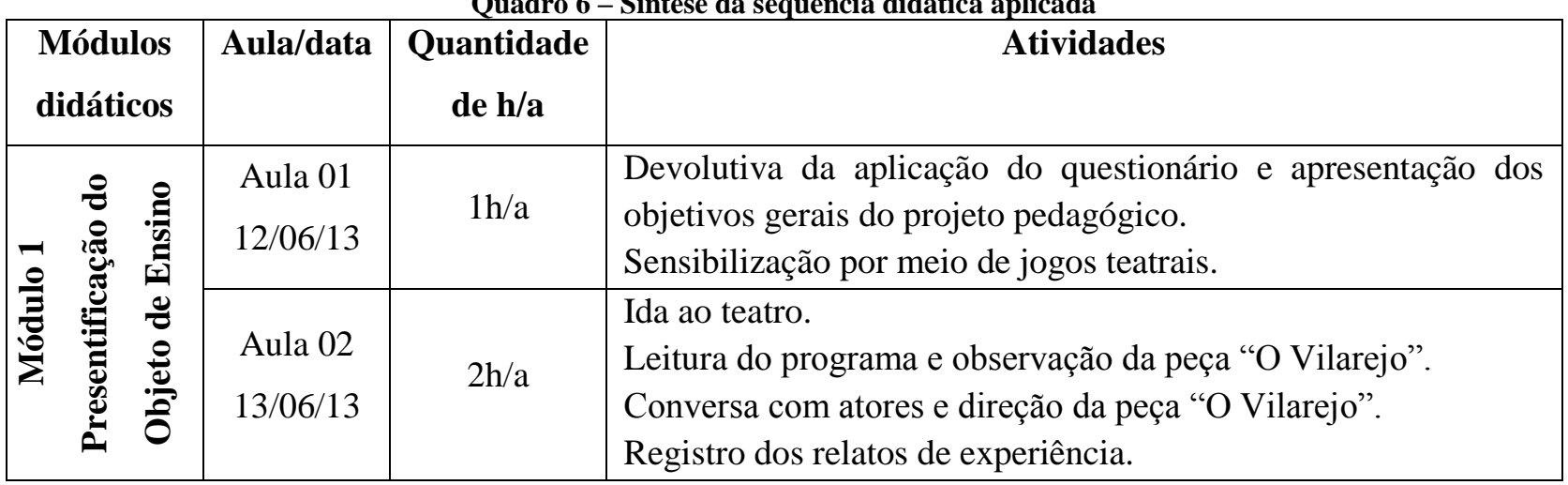




\begin{tabular}{|c|c|c|c|c|}
\hline \multirow{2}{*}{\multicolumn{2}{|c|}{ 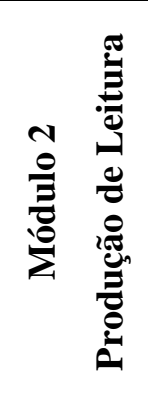 }} & $\begin{array}{l}\text { Aula } 03 \\
21 / 06 / 13\end{array}$ & $1 \mathrm{~h} / \mathrm{a}$ & $\begin{array}{l}\text { Observação da organização global do texto dramático escrito. } \\
\text { Estudo da estrutura composicional e do estilo do texto } \\
\text { dramático escrito: rubricas e pontuação. }\end{array}$ \\
\hline & & $\begin{array}{l}\text { Aula } 04 \\
26 / 06 / 13\end{array}$ & $1 \mathrm{~h} / \mathrm{a}$ & $\begin{array}{l}\text { Leitura de uma cena teatral da peça "Flor do meu jardim". } \\
\text { Atividade de fixação da estrutura composicional e do estilo do } \\
\text { texto dramático escrito. } \\
\text { Observação da esfera de circulação do texto dramático escrito. }\end{array}$ \\
\hline \multirow{10}{*}{$\frac{\infty}{e^{0}}$} & \multirow{10}{*}{ 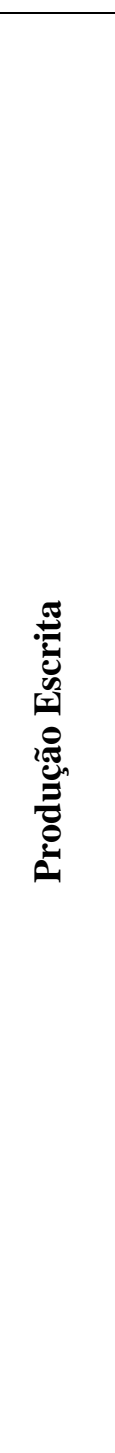 } & $\begin{array}{l}\text { Aula } 05 \\
03 / 07 / 13\end{array}$ & $2 \mathrm{~h} / \mathrm{a}$ & $\begin{array}{l}\text { Criação de rubricas para o diálogo entre duas personagens. } \\
\text { Elaboração da continuidade de uma cena teatral da peça "Flor } \\
\text { do meu jardim". } \\
\text { Encaminhamento de atividade para as férias: leitura de peça } \\
\text { teatral. }\end{array}$ \\
\hline & & $\begin{array}{l}\text { Aula } 06 \\
31 / 07 / 13\end{array}$ & $1 \mathrm{~h} / \mathrm{a}$ & $\begin{array}{l}\text { Planejamento geral da produção escrita do texto dramático: } \\
\text { definição do cenário, das personagens e do tema. }\end{array}$ \\
\hline & & $\begin{array}{l}\text { Aula } 07 \\
14 / 08 / 13\end{array}$ & $1 \mathrm{~h} / \mathrm{a}$ & Produção das sinopses das cenas $01,02,03,04$ e 05. \\
\hline & & $\begin{array}{l}\text { Aula } 08 \\
23 / 08 / 13\end{array}$ & $1 \mathrm{~h} / \mathrm{a}$ & Elaboração da primeira versão das cenas 01 e 03. \\
\hline & & $\begin{array}{l}\text { Aula } 09 \\
06 / 09 / 13\end{array}$ & $1 \mathrm{~h} / \mathrm{a}$ & $\begin{array}{l}\text { Correção colaborativa das cenas } 01 \text { e } 03 \text {. } \\
\text { Elaboração da primeira versão das cenas } 02,04 \text { e } 05 \text {. }\end{array}$ \\
\hline & & $\begin{array}{l}\text { Aula } 10 \\
13 / 09 / 13\end{array}$ & $1 \mathrm{~h} / \mathrm{a}$ & $\begin{array}{l}\text { Correção colaborativa das cenas } 02,04 \text { e } 05 \text {. } \\
\text { Produção das sinopses das cenas } 06,07 \text { e } 08 \text {. }\end{array}$ \\
\hline & & $\begin{array}{l}\text { Aula } 11 \\
\text { 20/09/13 }\end{array}$ & $1 \mathrm{~h} / \mathrm{a}$ & Elaboração da primeira versão das cenas 06,07 e 08. \\
\hline & & $\begin{array}{l}\text { Aula } 12 \\
27 / 09 / 13\end{array}$ & $1 \mathrm{~h} / \mathrm{a}$ & $\begin{array}{l}\text { Correção colaborativa das cenas } 06,07 \text { e } 08 . \\
\text { Produção das sinopses das cenas } 09 \text { e } 10 .\end{array}$ \\
\hline & & $\begin{array}{l}\text { Aula } 13 \\
04 / 10 / 13\end{array}$ & $1 \mathrm{~h} / \mathrm{a}$ & Elaboração da primeira versão das cenas 09 e 10. \\
\hline & & $\begin{array}{l}\text { Aula } 14 \\
23 / 10 / 13\end{array}$ & $1 \mathrm{~h} / \mathrm{a}$ & $\begin{array}{l}\text { Correção colaborativa das cenas } 09 \text { e } 10 . \\
\text { Criação do título do texto dramático. }\end{array}$ \\
\hline \multirow{3}{*}{\multicolumn{2}{|c|}{ 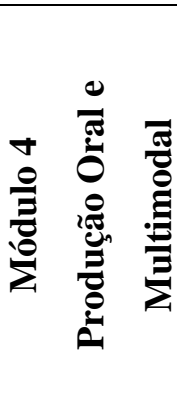 }} & $\begin{array}{l}\text { Aula } 15 \\
28 / 10 / 13\end{array}$ & $1 \mathrm{~h} / \mathrm{a}$ & $\begin{array}{l}\text { Leitura dramática do texto produzido. } \\
\text { Encaminhamento de atividade para casa: leitura do texto } \\
\text { dramático escrito, com vistas à escolha da personagem. }\end{array}$ \\
\hline & & $\begin{array}{l}\text { Aula } 16 \\
01 / 11 / 13\end{array}$ & $1 \mathrm{~h} / \mathrm{a}$ & $\begin{array}{l}\text { Estudo do texto dramático com vistas à compreensão da } \\
\text { personagem. }\end{array}$ \\
\hline & & $\begin{array}{l}\text { Aula } 17 \\
04 / 11 / 13\end{array}$ & $1 \mathrm{~h} / \mathrm{a}$ & Marcação das cenas $01,02,04$ e 10 com apoio do texto escrito. \\
\hline
\end{tabular}




\begin{tabular}{|c|c|c|c|}
\hline & $\begin{array}{l}\text { Aula } 18 \\
08 / 11 / 13\end{array}$ & $1 \mathrm{~h} / \mathrm{a}$ & $\begin{array}{l}\text { Marcação das cenas } 03 \text { e } 05 \text { com apoio do texto escrito. } \\
\text { Ensaio das cenas marcadas na aula anterior, com vistas à } \\
\text { memorização das falas. }\end{array}$ \\
\hline & $\begin{array}{l}\text { Aula } 19 \\
11 / 11 / 13\end{array}$ & $2 \mathrm{~h} / \mathrm{a}$ & $\begin{array}{l}\text { Marcação das cenas } 06,07,08 \text { e } 09 \text { com apoio do texto escrito. } \\
\text { Ensaio das cenas marcadas na aula anterior, com vistas à } \\
\text { memorização das falas. }\end{array}$ \\
\hline & $\begin{array}{l}\text { Aula } 20 \\
22 / 11 / 13\end{array}$ & $1 \mathrm{~h} / \mathrm{a}$ & $\begin{array}{l}\text { Ensaio das cenas marcadas na aula anterior, com vistas à } \\
\text { memorização das falas. }\end{array}$ \\
\hline & $\begin{array}{l}\text { Aula } 21 \\
25 / 11 / 13\end{array}$ & $1 \mathrm{~h} / \mathrm{a}$ & $\begin{array}{l}\text { Ensaio geral com auxílio do texto escrito, observando: } \\
\text { acréscimos ou supressões, improvisações, escolha de } \\
\text { vocabulário, modos de falar, expressar-se e se movimentar. }\end{array}$ \\
\hline & $\begin{array}{l}\text { Aula } 22 \\
27 / 11 / 13\end{array}$ & $2 \mathrm{~h} / \mathrm{a}$ & $\begin{array}{l}\text { Elaboração de cartazes para divulgação da peça. } \\
\text { Criação do programa da peça. } \\
\text { Levantamento dos itens necessários para o cenário. } \\
\text { Levantamento dos figurinos. } \\
\text { Estabelecimento da sonoplastia da peça. }\end{array}$ \\
\hline 倠 & $\begin{array}{l}\text { Aula } 23 \\
02 / 12 / 13\end{array}$ & $4 \mathrm{~h} / \mathrm{a}$ & $\begin{array}{l}\text { Jogo teatral. } \\
\text { Leitura do texto no teatro. } \\
\text { Ensaios com cenário e sonoplastia. } \\
\text { Ensaios com figurino e iluminação. } \\
\text { Aquecimento vocal e corporal. } \\
\text { Entrega do programa à plateia no início do espetáculo. } \\
\text { Apresentação da peça "Festa de Aniversário" aos alunos do } \\
\text { turno da tarde do Colégio. } \\
\text { Entrega do texto completo à plateia ao final do espetáculo. } \\
\text { Registro dos relatos de experiência. }\end{array}$ \\
\hline & & & $\begin{array}{r}\text { Total de horas-aula } \\
30 \mathrm{~h} / \mathrm{a}\end{array}$ \\
\hline
\end{tabular}

Depreendemos do Quadro 6 que, para realização da sequência didática, foram necessárias 30h/a, assim divididas: dois (02) encontros para o desenvolvimento do Módulo 1 - Presentificação do Objeto de Ensino (Aulas 01 e 02, totalizando 3h/a), dois (02) encontros para o Módulo 2 - Produção de Leitura (Aulas 03 e 04, totalizando 2h/a), dez (10) encontros para o Módulo 3 - Produção Escrita (Aulas 05 a 14, totalizando 11h/a), sete (07) encontros para o Módulo 4 - Produção Oral e Multimodal (Aulas 15 a 21, totalizando 8h/a) e dois (02) encontros para o Módulo 5 (Aulas 22 e 23, totalizando 6h/a). Com isso, observamos que a carga horária maior concentrou-se nas atividades de produção do texto dramático (escrito, oral e multimodal) e nas práticas que envolvem a esfera teatral (produção de cartazes e programa, organização do espetáculo - cenário, figurinos e sonoplastia). 
Descrevemos, nas próximas seções, as atividades desenvolvidas nos cinco (05) módulos didáticos propostos neste projeto pedagógico.

\subsubsection{Módulo 1 - Presentificação do Objeto de Ensino}

O Módulo 1, por nós intitulado, "Presentificação do Objeto de Ensino", recobriu as Aulas 01 e 02. Retomamos, para tanto, o que foi sugerido no capítulo I deste trabalho, a fim de que pudéssemos propiciar aos alunos, no início de um projeto pedagógico com gêneros discursivos, o contato com o objeto de estudo proposto, visando, assim, sua imersão em atividades contextualizadas que oportunizassem a produção/recepção do gênero.

Desta forma, para iniciar o trabalho com o gênero texto dramático (escrito e oralizado/representado), entendemos a necessidade de se proceder a inúmeras motivações, dentre as quais se destacam: sensibilização à esfera teatral por meio de jogos (Aula 01) e ida ao teatro (Aula 02). Nas linhas que seguem, descrevemos as atividades desenvolvidas nesse módulo, junto aos alunos participantes desta pesquisa-ação.

Na Aula 01, efetivamos a devolutiva da aplicação do questionário, no sentido de explicitar o porquê de o $8^{\circ}$ ano $\mathrm{E}$ ter sido selecionado para intervenção didática, tendo em vista as demais turmas da escola que, também, assim como eles, haviam respondido ao questionário.

Schneuwly e Dolz (2004) orientam para a importância de se esclarecer os alunos, no início da sequência didática, quanto aos objetivos visados e o itinerário a percorrer para atingi-los. Desse modo, mencionamos aos alunos que seriam realizadas atividades nas aulas de língua portuguesa em torno do texto dramático: ler peças teatrais, escrever coletivamente uma peça e, finalmente, encenar a peça que eles mesmos escreveriam.

Na sequência da aula, procedemos à aplicação de jogos fundamentados nos estudos teatrais, para que estabelecêssemos o primeiro contato com a turma e ilustrássemos alguns objetivos do projeto pedagógico. Entendemos que os jogos constituem o primeiro passo na aprendizagem teatral. Alguns estudos voltados aos jogos teatrais, como os de Japiassu (2001, 2007), Ryngaert (2009) e Spolin (2010), têm mostrado o caráter insubstituível desse método 
também nas aprendizagens escolares. Conforme assinala Spolin (2010), os jogos teatrais são atividades pedagógicas que levam ao domínio e à fluência da comunicação por meio do teatro. Além disso, segundo Telles (2009), os jogos buscam instrumentalizar os alunos para o conhecimento teatral básico, por meio da vivência de atividades que permitem a ampliação de suas capacidades expressivas e de sua consciência de grupo.

Diante dessas considerações, na Aula 01, selecionamos dois (02) jogos fundamentados em nossa experiência em oficinas de teatro para preparação de atores -, a fim de que pudéssemos estabelecer o vínculo com os alunos e inseri-los no contexto de produção do gênero texto dramático.

A seguir, procedemos à descrição da aplicação desses jogos, que têm por objetivo: propiciar a descontração da turma (Jogo 01: Que animal eu sou?) e estimular o trabalho em equipe, evidenciando, assim, uma das particularidades do teatro (Jogo 02: Bolinhas coloridas).

\section{Aplicação do jogo 01: Que animal eu sou?}

Posicionamos a turma em círculo e iniciamos a explicação do jogo, perguntando aos alunos se eles conheciam a mímica, atividade tão próxima do universo teatral. Solicitamos que eles falassem nomes de animais e imaginassem como seria imitá-los para toda turma. Neste momento, alguns alunos começaram a ficar receosos e aflitos, dizendo que não queriam imitar animal algum.

Entregamos um papel para cada aluno, dizendo que havíamos escrito o nome de vários animais e pedimos para que eles não mostrassem para o colega nem comentassem sobre o animal sorteado. Empregamos bastante suspense neste momento, para que, de fato, fosse criada uma expectativa diante do jogo.

Solicitamos, em seguida, que apenas pensassem naquele animal: como ele se movimentava? Qual som emitia? Qual sua textura? Seu tamanho? Sua cor? Revelamos, então, o comando do jogo: "quando você ouvir o nome do seu animal, imediatamente, tente se sentar no chão, sem soltar as mãos dos colegas a seu lado".

No entanto, o que os alunos não sabiam é que em todos os papéis estava escrita a palavra "macaco" e quando eles ouvissem o nome deste animal, todos sentariam ao mesmo tempo. Assim, no momento em que gritamos "macaco!", todos, sem exceção, caíram no chão, sentados, de mãos dadas. Alguns alunos riram, outros ficaram indignados e se pronunciaram: "mas eu era o macaco!", "eu também!", "não, gente, todo mundo era o macaco". Na sequência, fizeram outros comentários: "nossa... pensei que eu ia ter que imitar o bicho aí", "e eu pensei que quem errasse o jogo ia ter que pagar um mico no meio da roda, imitando o bicho", "e eu pensei que ia ter que fazer um macaco". 
A aplicação desse jogo auxiliou na quebra de expectativa diante do próprio jogo, revelando-se, assim, como uma ilustração do que aconteceria em todas as aulas que se seguiriam no projeto. Em outras palavras, o que se sabia até aquele momento era que escreveriam um texto dramático, que seria encenado posteriormente; entretanto, para realizar as atividades que conduziriam a esse objetivo, seria preciso comprometimento - assim como eles revelaram ao cumprir com a proposta do jogo.

A aplicação desse jogo reforça o fato de que cada etapa do projeto pedagógico em torno do gênero texto dramático, conforme entendemos, pode ser explorada ao máximo e as atividades selecionadas para a aproximação da esfera que o engendra - o teatro - merecem ser, sobretudo, vivenciadas. Nesse sentido, Reverbel (2007) ressalta que, se o aluno desenvolver suas capacidades de expressão - aí incluídas espontaneidade, percepção, observação, imaginação e relacionamento grupal - estará aberto para todo o tipo de aprendizagem.

O segundo jogo teatral aplicado nesta aula exigiu concentração dos alunos e trabalho em equipe - a nosso ver, aspectos fundamentais para produção escrita e oral do gênero texto dramático.

\section{Aplicação do jogo 02: Bolinhas coloridas}

Dispostos em círculo, explicitamos aos alunos que deveriam lançar uma bolinha colorida ao colega, de modo a realizar sempre a mesma sequência. Permitimos, inicialmente, que eles fizessem várias vezes a mesma sequência, até se sentirem confiantes para a inserção de uma nova bolinha.

Quando começamos a inserir mais bolinhas, e estas tinham de ser lançadas simultaneamente, os alunos ficaram muito ansiosos, falavam sem parar, se atrapalhavam e deixavam a bolinha cair. A cada bolinha no chão, o jogo recomeçava. Quando isso acontecia, os alunos culpavam uns aos outros, “a culpa é sua!", "presta atenção!". Em uma dessas falas, um aluno sugeriu ao outro que olhasse apenas para ele, já que recebia a bolinha apenas dele, e não ficasse prestando atenção nos outros, muito menos nas bolinhas girando no ar.

Perguntamos a eles, finalmente: “este jogo é individual?". Eles responderam que "não, é em grupo", então, complementamos, "se um errar, todos erram, não é isso? O que é preciso para vocês conseguirem fazer cinco bolinhas girarem na sequência, sem cair no chão?", eles responderam, "ter atenção", "cuidado" e "concentração". Após sete minutos, os alunos conseguiram cumprir com o objetivo do jogo. Eles disseram que estavam satisfeitos com o resultado, mas que foi muito difícil alcançá-lo. 
A aplicação desse jogo nos faz refletir a respeito da natureza coletiva em que se situam as atividades da esfera teatral. Nessa direção, Peixoto (1986, p.49) considera o teatro uma "arte grupal em todos os níveis: produzido graças ao esforço orgânico de muitos, dirige-se ao consumo de muitos".

Tomando o texto dramático como objeto de ensino de língua portuguesa, é possível reconhecer a interação como um dos aspectos preponderantes, visto que é necessária a participação e o envolvimento de todos, seja na produção colaborativa do texto escrito ou nas atividades que envolvem a produção oral e a montagem do espetáculo teatral.

Com intuito de motivar os alunos do $8^{\circ}$ ano $\mathrm{E}$ a empenhar-se nas atividades que levariam à produção do texto dramático escrito e de sua representação, conduzimos, como atividade seguinte, uma aula fora do ambiente escolar - em um teatro da cidade (Teatro Barracão $)^{47}$. O objetivo inicial ao levar os alunos ao teatro foi distanciá-los da sala de aula, para que eles pudessem vivenciar o momento único e privilegiado de acesso real a uma das práticas discursivas estreitamente relacionadas ao nosso objeto de estudo - a representação cênica - já que, conforme explicitam alguns estudiosos do teatro, "uma peça só se revela em toda a sua essência e plenitude ao ser representada num palco" (STANISLAVSKI, 1997, p.163).

Com a proposição dessa atividade, buscamos conhecer a recepção dos alunos em relação ao texto dramático oralizado/representado, tendo em vista que o público de uma peça de teatro também participa efetivamente da representação. Para Chacra (2010), enquanto ocorre o espetáculo teatral, sua totalidade vai-se completando na interação entre atores e público.

Desse modo, organizamos, para a Aula 02, a atividade "ida ao teatro". Para valorizar a participação dos alunos do $8^{\circ}$ ano E como plateia, entregando-lhes um convite especial ${ }^{48}$, ressaltando, assim, a importância da presença de cada um deles neste dia de aula. Informamos, ainda, que se sentariam nas primeiras fileiras e poderiam, ao final da apresentação, conhecer o espaço do teatro e conversar com o elenco da peça. Junto à entrega do convite, disponibilizamos, também, uma autorização a ser preenchida pelos pais ou

\footnotetext{
${ }^{47}$ É válido mencionar que os ônibus que levaram os alunos ao teatro foram disponibiliza pela prefeitura. Devido ao fato de se constituir atividade de uma instituição pública, houve, também, isenção da taxa para utilização do teatro.

${ }^{48}$ Cf. Anexo VII.
} 
responsáveis dos alunos ${ }^{49}$. A atividade realizou-se no período de aula e os alunos deslocaramse de ônibus até o teatro. No local da apresentação, eles foram recepcionados com o programa da peça "O Vilarejo ${ }^{50 "}$.

De posse desse material, procedemos à explicação de que o programa de uma peça teatral presta-se a informar ao espectador: título, nome dos/as atores/atrizes e respectivas personagens, nome dos responsáveis pela técnica (cenário, sonoplastia, iluminação), pela autoria do texto e pela direção.

É significativo destacar que a peça "O Vilarejo" é de nossa autoria e direção ${ }^{51}$. Do elenco constavam alunos de ensino fundamental de outra escola, na qual já ministramos aulas de teatro. Sabemos que, a viabilidade desta proposta restringe-se às especificidades desta pesquisa, mas a possibilidade de realizá-la em outros contextos de ensino e aprendizagem nos faz otimistas, pois há, certamente, uma aproximação imediata ao ver alunos em cena, ao invés de atores profissionais, fazendo deste encontro, a nosso ver, uma experiência enriquecedora. Em outras palavras, ao partilharem de uma condição real de se projetarem no palco, os alunos passam a se identificar mais com a prática teatral.

Apresentamos, a seguir, algumas Imagens (10 a 13) que buscam registrar a história encenada para os alunos participantes desta pesquisa-ação.
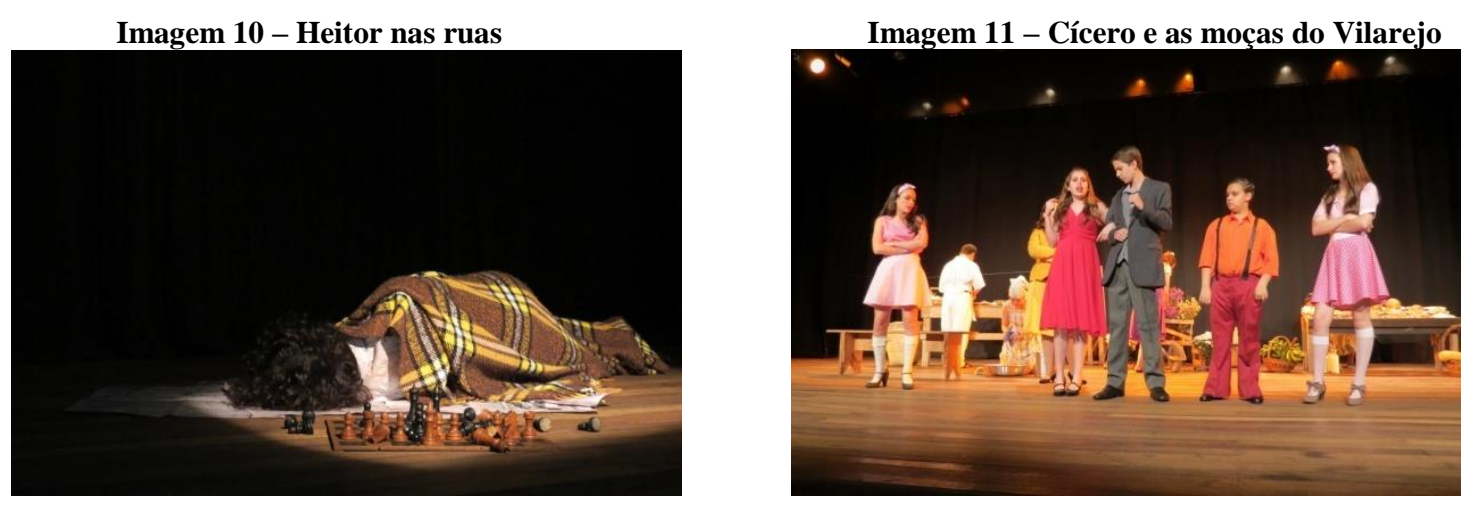

\footnotetext{
${ }^{49}$ Cf. Anexo VIII.

${ }^{50} \mathrm{Cf}$. Anexo IX.

${ }^{51}$ A escolha por textos de nossa autoria passa, em primeira instância, pela necessidade de aproximar os alunos à possibilidade de produção escrita de um texto dramático, oferecendo-lhes, assim, uma referência acessível.
} 

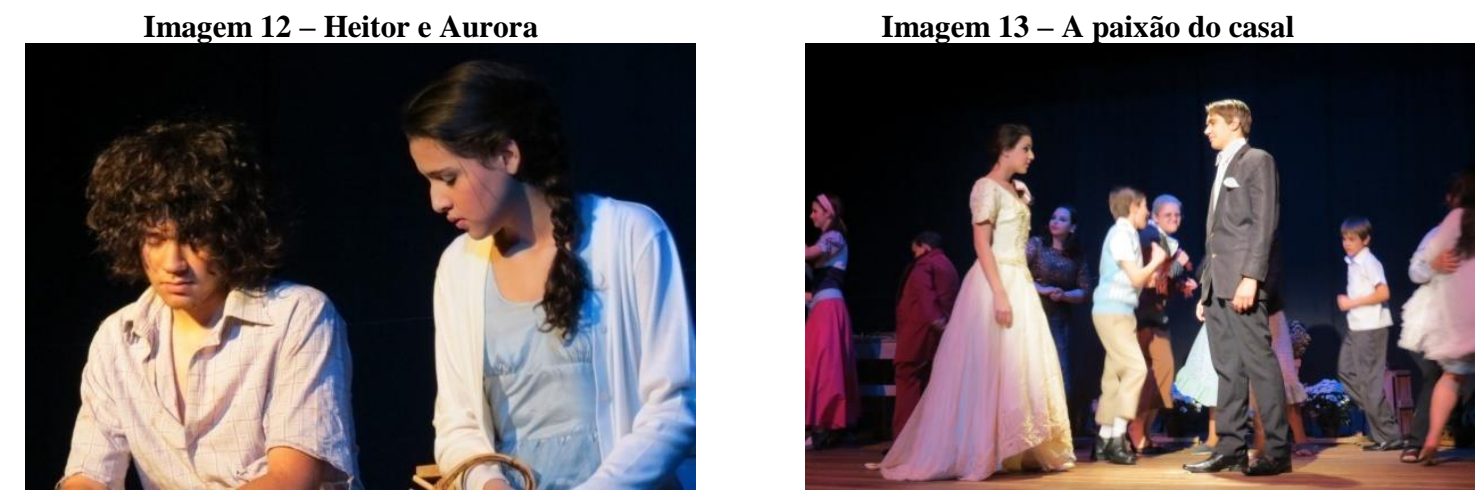

Durante cinquenta (50) minutos, os alunos assistiram à peça "O Vilarejo", que teve por temática a essência do ser humano e, ao final, puderam conversar com o elenco, revelando suas curiosidades em relação à história representada e à montagem da peça como um todo, conforme podemos observar na Imagem 10 - alunos do $8^{\circ}$ ano E, sentados na primeira fileira da plateia; e na Imagem 14 - elenco da peça “O Vilarejo”, sentado no palco.
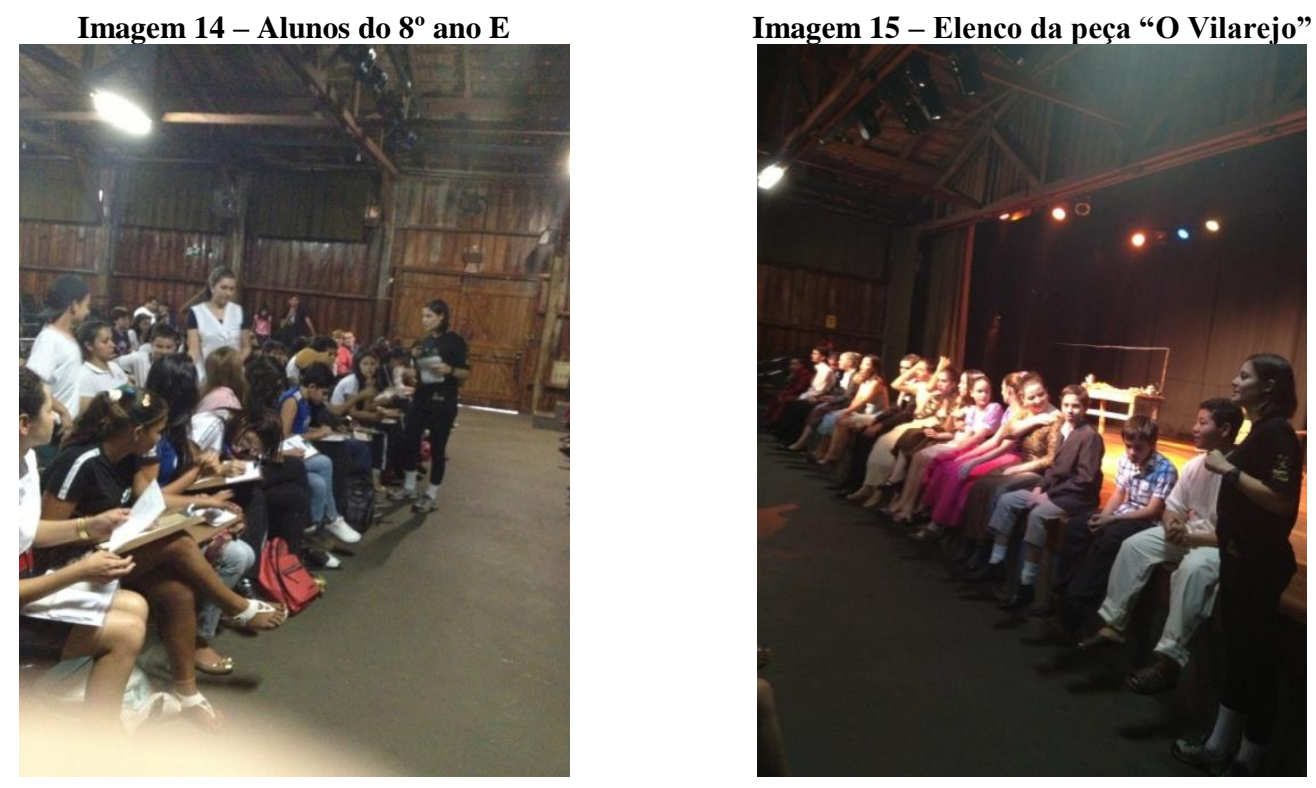

Propusemos aos alunos que registrassem suas perguntas em torno dos seguintes temas: criação do texto, memorização das falas, ensaios, intenção das falas (modo de falar), criação da personagem, gestos e movimento corporal das personagens, direção das cenas, cenário, figurino, iluminação e sonoplastia. 
O tema mais abordado pelos alunos foi "memorização das falas" e, dentre as perguntas realizadas, destacaram-se: "É muito difícil?", "Vocês usam alguma técnica?", "Vocês improvisam às vezes?". Quanto aos ensaios, um aluno questionou, "Foi difícil ensaiar?", e outro acrescentou, "Foi difícil ensaiar com a sonoplastia?". E, ainda, sobre a criação do texto, um aluno perguntou: "Foi muito difícil de fazer?".

Ressaltamos a palavra "difícil” nessas perguntas, porque ela foi repetida inúmeras vezes pelos alunos ao longo dessa atividade. Observamos, com isso, que, para essa turma, o texto dramático oralizado/representado era um gênero "inalcançável”, tamanha a dificuldade que eles imprimiram ao falar sobre essa prática.

Parece-nos oportuno retomar, nesse momento, os postulados dos pesquisadores genebrinos, para quem as sequências didáticas permitem aos alunos terem acesso a práticas de linguagem consideradas novas ou dificilmente domináveis e cuja proposta só assume seu sentido completo "se as atividades desenvolvidas em sala de aula, e não o material à disposição, forem determinadas pelas dificuldades encontradas pelos alunos na realização da tarefa proposta" (DOLZ; NOVERRAZ; SCHNEUWLY, 2004, p.107).

Faz-se necessário destacar que os resultados obtidos nos questionários respondidos pelos alunos participantes desta pesquisa-ação já haviam apontado para o fato de que pouquíssimos alunos do $8^{\circ}$ ano $\mathrm{E}$ tiveram a oportunidade de assistir a uma peça de teatro fora da escola (dos dezessete alunos, apenas quatro responderam afirmativamente à questão). Essa se constituiu, pois, uma das razões para a escolha da atividade inicial "ida ao teatro". Do mesmo modo, o resultado desta atividade determinou os rumos de nossa sequência didática, pois o interesse dos alunos no processo de memorização de falas, ensaios e produção do texto escrito levou-nos a pensar em atividades diversificadas, ao longo do projeto pedagógico, para que os alunos pudessem se familiarizar com o gênero, de forma a motivá-los - mesmo diante da dificuldade apontada - a também produzi-lo. Conforme asseguram os estudos voltados para a didática, dos quais destacamos Libâneo (1994), o planejamento escolar solicita do professor uma constante tarefa de previsão e revisão; nesse sentido, os planos de aula podem constituir processo criativo e flexível: na preparação e no tratamento didático dos conteúdos escolares, na aplicação e na consolidação de conhecimentos e habilidades e na avaliação dos resultados. 
Após a conversa com atores e direção da peça, os alunos puderam, sob nossa orientação, conhecer o espaço do teatro (palco, coxias, camarins e técnica) - conforme evidencia a Imagem 16, a seguir. Além disso, ao final da aula, registraram sua experiência quanto à atividade proposta naquele dia.

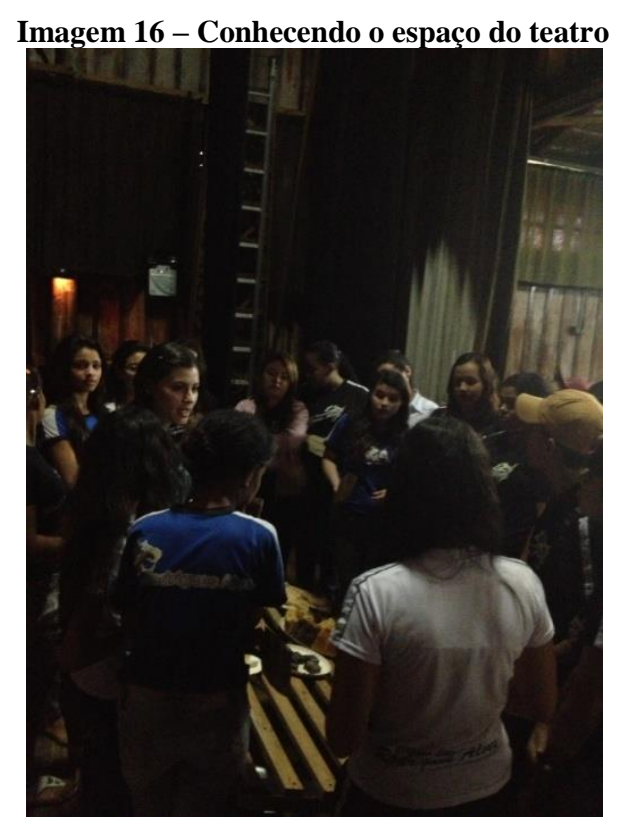

Ainda no teatro, os alunos puderam escrever sua emoção/sensação de assistir à peça “O Vilarejo". Selecionamos, a seguir, algumas respostas que, em poucas palavras, simbolizam o efeito catártico e irreparável desta experiência teatral para estes alunos, especialmente:
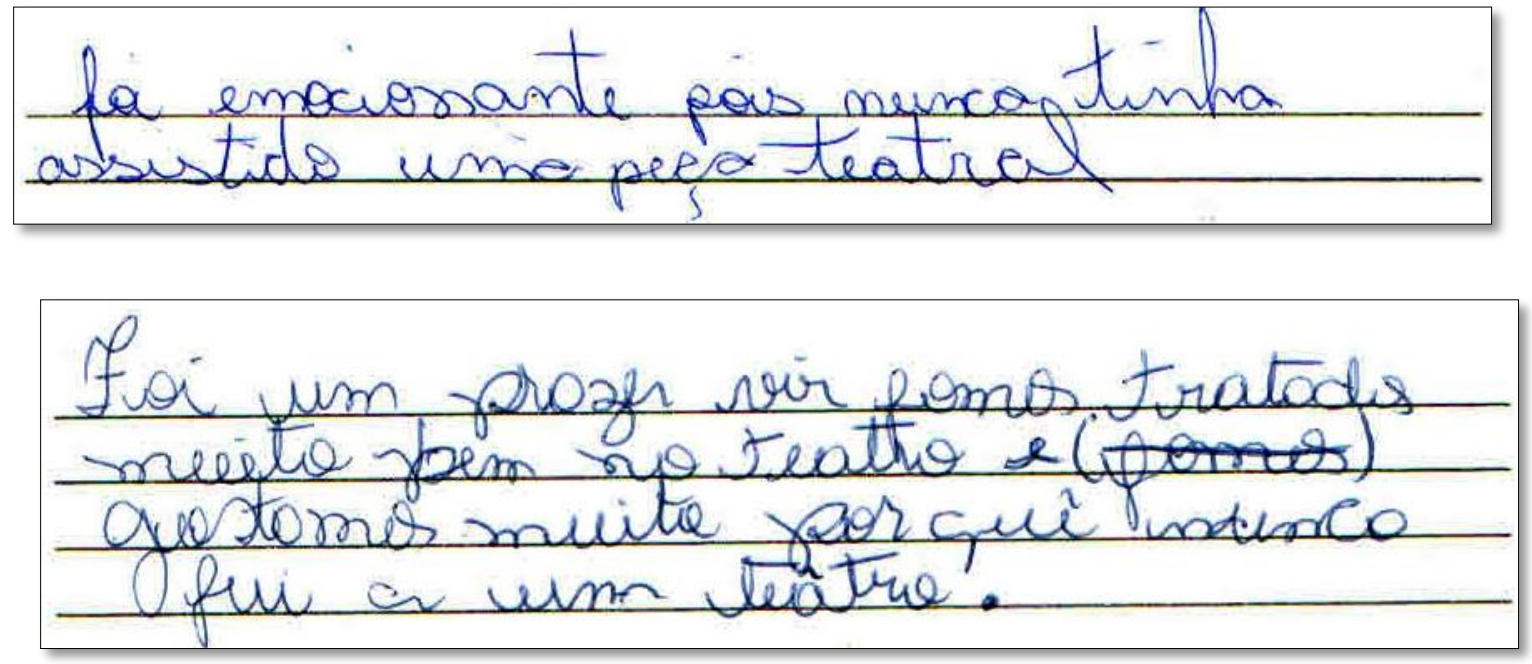


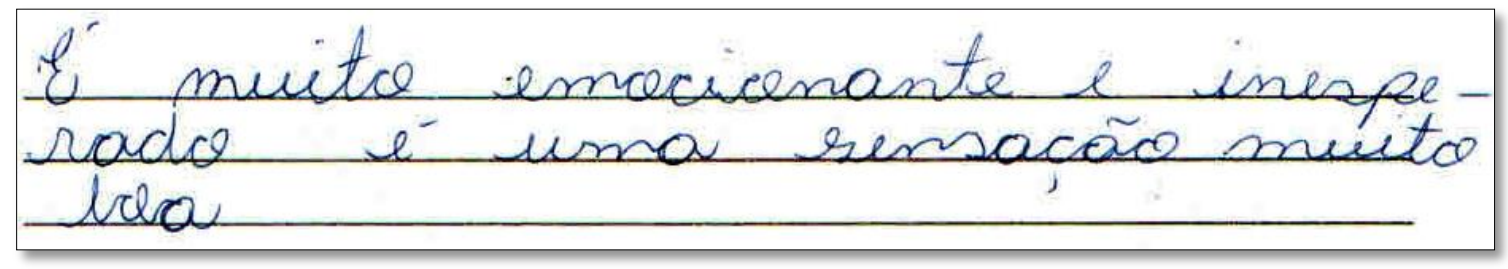

\section{A sensorair ede alegrio e priviligre

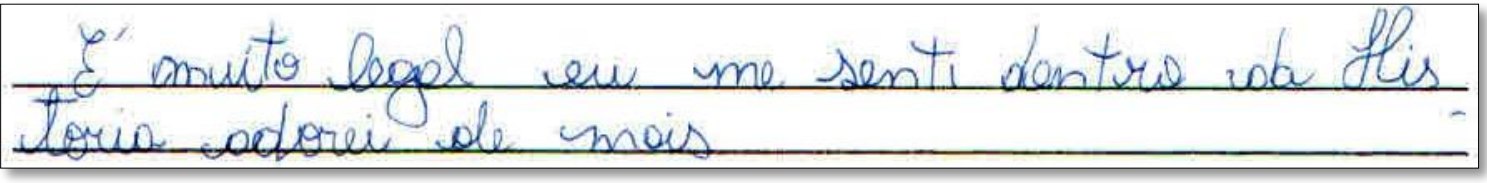

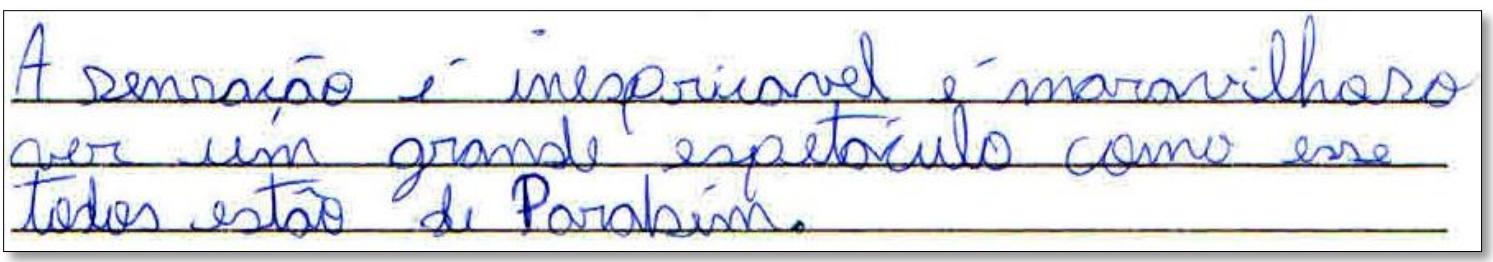
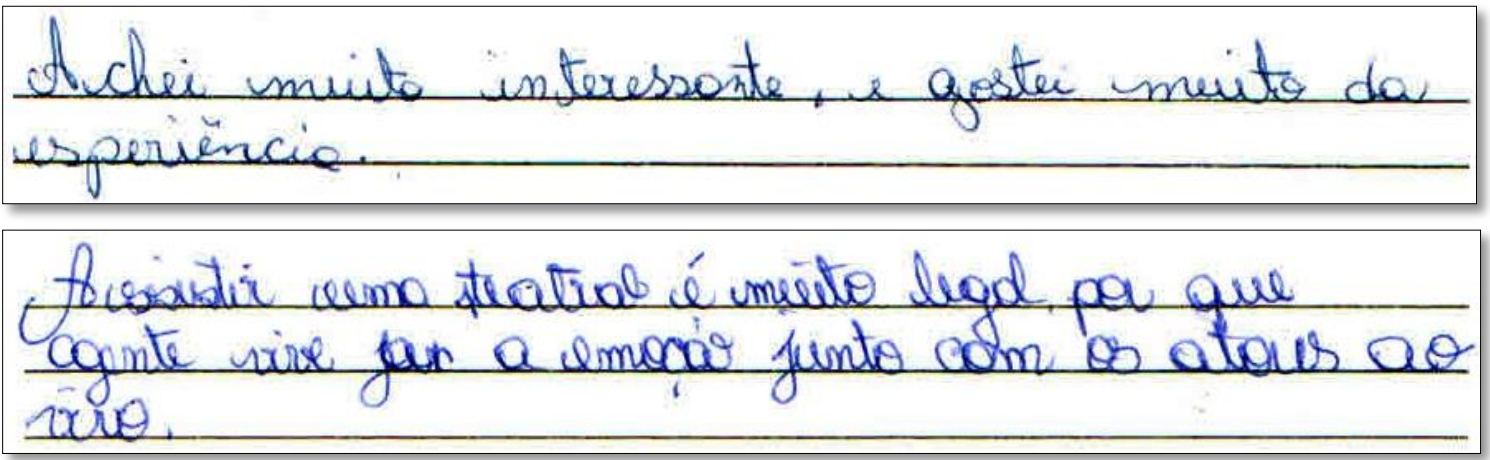

Para registrarem a experiência, os alunos selecionaram palavras positivas como “emocionante", "legal” "sensação boa", "sensação de alegria e privilégio", "inexplicável”, "sensação maravilhosa", e enfatizaram com a negativa "nunca", o fato de alguns não terem tido a oportunidade de ir ao teatro.

Esses depoimentos nos fazem pensar sobre o papel social da escola - e também da disciplina Língua Portuguesa - em propiciar situações de aprendizagem como essa, em que práticas interativas permitem expandir, por exemplo, a competência genérica e, mais amplamente, o repertório cultural dos alunos. Nessa direção, Lopes-Rossi (2002a, p.29) afirma que, "por suas características típicas, cada gênero tem de ser conhecido e praticado em experiências sociais ou escolares significativas". 
Assim, ao oportunizarmos a sensibilização do gênero texto dramático por meio de atividades imersas na esfera teatral - realizar jogos, assistir a uma peça, conversar com elenco e direção, ir ao teatro e conhecer seu espaço -, objetivamos motivá-los para o projeto pedagógico a ser desenvolvido e, de maneira mais ampla, transformá-los para a vida, pois, conforme entendemos, ao ser interpelado pelo teatro, o aluno (o ser humano), de algum modo, modifica-se.

Após a dedicação de duas aulas para realização de atividades do Módulo 1 Presentificação do Objeto de Ensino, prosseguimos com a sequência didática em torno do texto dramático. A próxima seção deste capítulo busca apresentar as atividades desenvolvidas nas aulas dedicadas, desta vez, ao Módulo 2 - Produção de Leitura.

\subsubsection{Módulo 2 - Produção de Leitura}

O Módulo 2 - Produção de Leitura tem por objetivo levar o aluno a conhecer as condições de produção do gênero, a partir de exemplares alocados em sua esfera de circulação - seguimos, assim, a proposta de Lopes-Rossi (2011). Entendemos que este módulo é fundamental para a produção escrita do gênero que selecionamos, pois possibilita ao aluno observar as características composicionais e estilísticas do gênero, preparando-o para a produção escrita. Assim, nesta etapa da sequência didática, selecionamos atividades que oportunizassem aos alunos o contato mais estreito com o gênero texto dramático escrito, apresentando-lhes suas diferentes características, realizando um discurso sobre ele, fazendo-os observar, analisar, praticar, para que o gênero se tornasse, de fato, um objeto de estudo na sala de aula. Nesse sentido, observamos a orientação Koch (2009), para quem, na medida em que o objeto é descrito e explicitado, ele se torna acessível a todos - professor e alunos - nas práticas linguageiras de aprendizagem.

Apresentamos, a seguir, a descrição das Aulas 03 e 04, desenvolvidas neste Módulo, nas quais evidenciamos a apreensão da estrutura composicional e do estilo do texto dramático escrito a partir de atividades de leitura e fixação. 
Na Aula 03, disponibilizamos para cada aluno uma cópia, na íntegra, do texto dramático representado no teatro - "O Vilarejo". Procedemos à localização dos elementos que organizam o início do texto dramático escrito e da posição em que eles aparecem, conforme salientamos no Esquema 3, a seguir:

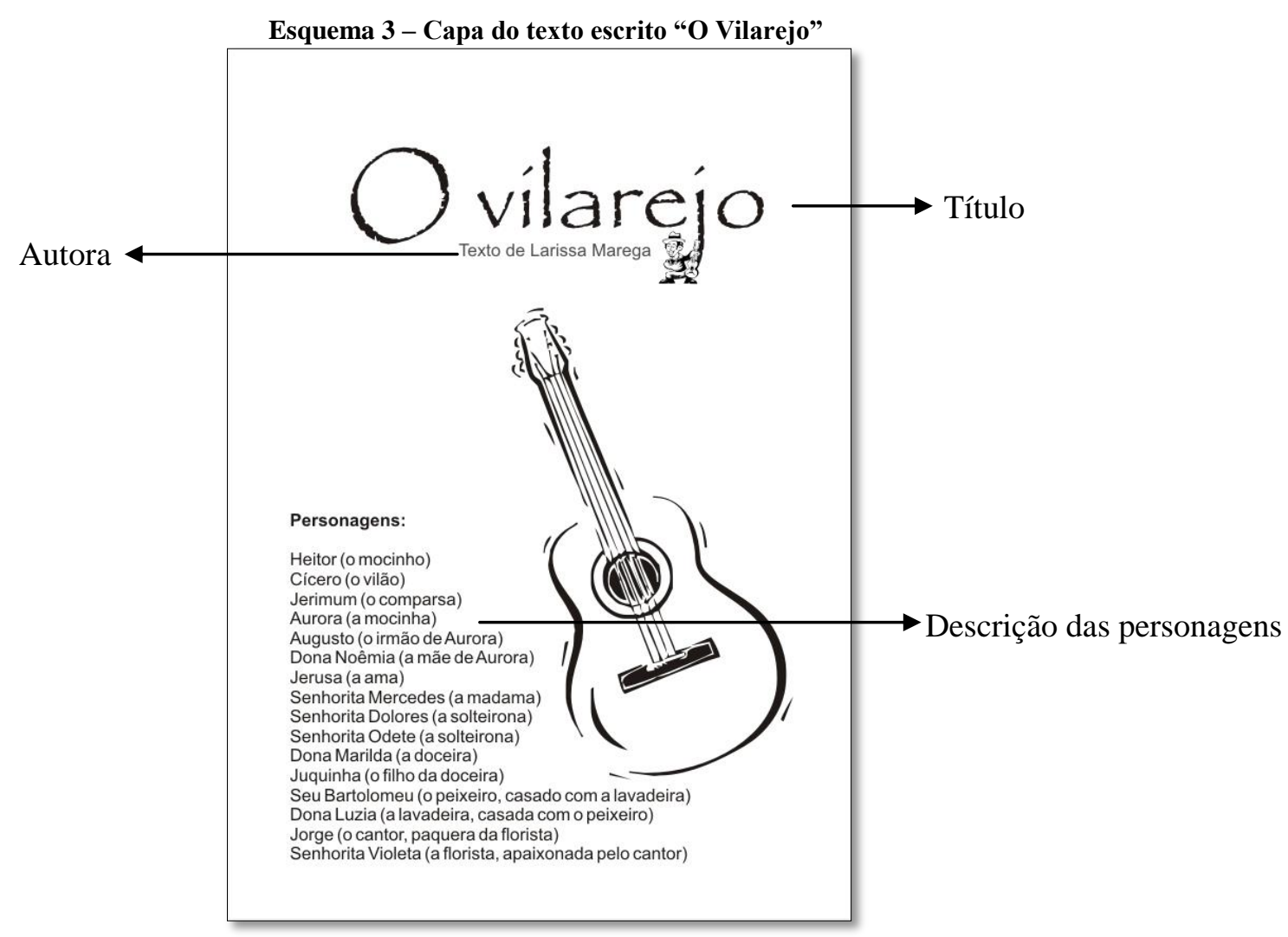

Certamente em razão de terem assistido à peça, ao receberem o texto dramático escrito de "O Vilarejo", os alunos ficaram bastante entusiasmados e expressaram vontade de lê-lo imediatamente. O texto comporta trinta e sete (37) páginas, assim, devido ao tempo destinado ao nosso contato semanal com a turma, não efetuamos a leitura completa do texto, mas indicamos que esta poderia ser realizada em casa, não como uma tarefa obrigatória, mas como uma maneira de se entreterem durante a semana. Como resposta a essa sugestão, na aula seguinte, três (03) alunos disseram ter lido o texto todo, afirmaram ter "gostado muito" e revelaram o interesse de ler "outros textos como esse". Esse fato levou-nos a pensar na possibilidade de facilitar o acesso dos alunos a mais textos dramáticos durante o desenvolvimento da sequência didática; esta ação foi concretizada na proposta de atividade para as férias, a qual descrevemos no final desta seção. 
No primeiro contato com o gênero texto dramático escrito, um dado significativo mereceu nossa atenção: um dos alunos, ao folhear o texto, questionou-nos, "Mas o texto é todo dividido em cenas?". Redirecionamos a pergunta a todos os alunos da sala e eles enfatizaram que não sabiam que aquela apresentação teatral - assistida na aula anterior - tinha por base essa estrutura. Os questionários aplicados à turma já haviam sinalizado o fato de a maioria dos alunos do $8^{\circ}$ ano E não tinha conhecimento do texto dramático escrito ${ }^{52}$. Esse dado parece reforçar a pertinência do Módulo 2 - Produção de Leitura para apreensão das características do gênero, pois com ele, é possível antecipar o levantamento de dificuldades, obstáculos e novidades a serem apreendidas no decorrer das aulas, conforme salienta Nascimento (2009).

Diante desse contexto, entendemos ser necessário, sempre que preciso, adaptar a sequência didática ao perfil dos alunos e às dificuldades por eles apresentadas, por meio da aplicação de um conjunto de atividades que facilitem a produção/recepção do gênero, a fim de que se possa, também, segundo Dolz, Noverraz e Schneuwly (2004, p.87), “desenvolver as capacidades de linguagem dos alunos que, apropriando-se dos instrumentos de linguagem próprios ao gênero, estarão mais preparados para realizar a produção final”.

Na sequência da Aula 03, promovemos, então, a identificação da macroestrutura do texto dramático, conforme destacamos à direita e à esquerda das margens do texto, presentens no Esquema 4, a seguir:

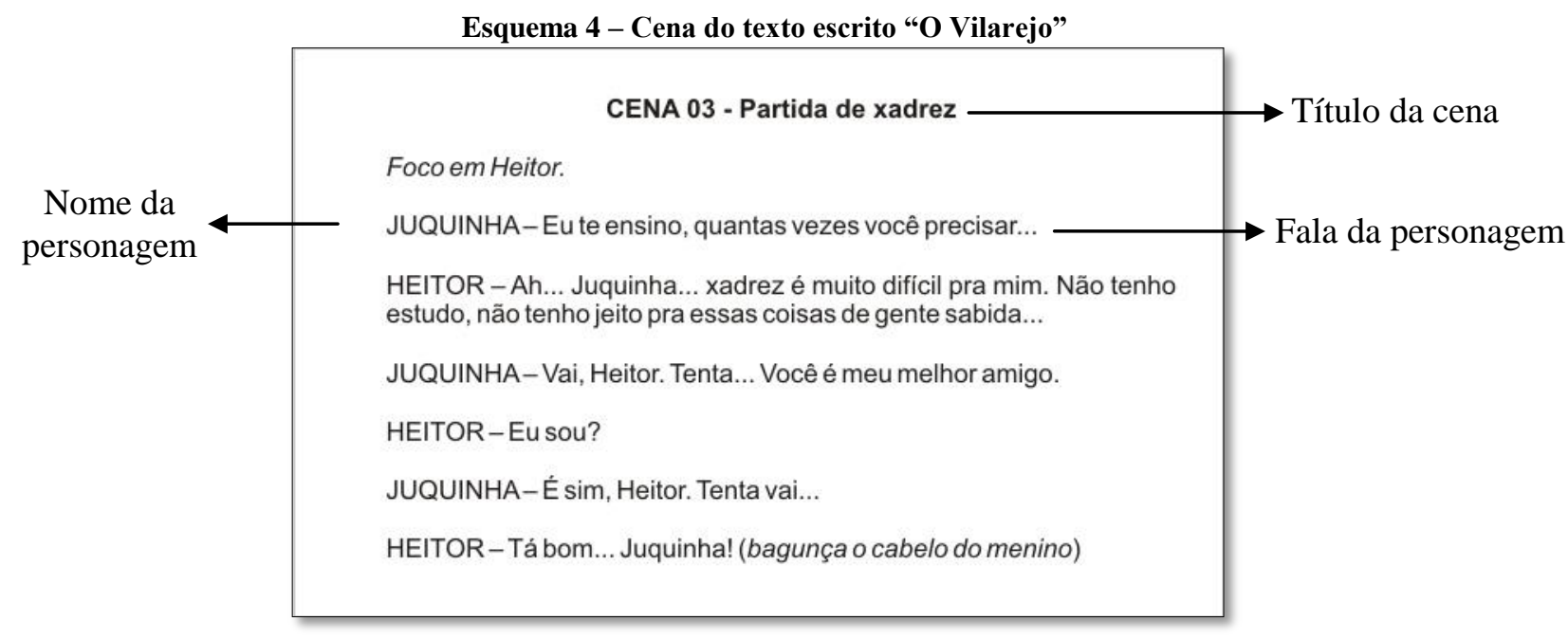

${ }^{52}$ Cf. Capítulo IV (p.156). 
Observamos, com os alunos, as razões pelas quais ocorre a mudança de cena no texto dramático escrito (registro da entrada/saída de personagens/mudança de cenário/mudança de assunto) e retomamos alguns exemplos do texto dramático representado. Os alunos mencionaram momentos da apresentação teatral e buscaram, no texto escrito, a forma de indicar a passagem de uma cena para outra. No Esquema 4, verificaram a expressão "foco em Heitor" e, em outras cenas, indicaram outras possibilidades, marcadas ora no início, ora no final da cena: "Os dois saem de cena", "Entra Jorge e para na barraca de Dona Violeta", "Cícero e Jerimum se aproximam do banco da praça", "Foco em Dona Marilda e Juquinha" etc.

Uma marcação sinalizada, nesta etapa, foi a expressão “cai a luz”, empregada no texto escrito para indicar a mudança de cena e, no texto representado, para indicar a mudança de iluminação, por exemplo, o escurecimento do palco para a entrada/saída de personagens. Os alunos desconheciam o uso dessa expressão e começaram a imaginar qual luz havia caído no palco na aula anterior. A marcação "cai o pano", para finalização do texto escrito, também foi questionada pelos alunos. Explicitamos que se tratava do fechamento das cortinas ao final da apresentação teatral.

O encaminhamento dessa atividade privilegiou a comparação entre as marcações do texto escrito e a rememoração das ações ou acontecimentos efetivados no espetáculo. A partir dos exemplos discutidos em sala, concluímos com os alunos que a representação cênica faz parecer o contínuo de uma história contada pelas personagens e o texto escrito faz registro dessa mesma história em pequenos blocos (cenas).

Tendo em vista que a organização típica de cada gênero deve ser conhecida por quem vai produzi-lo, conforme salienta Lopes-Rossi (2002c), conduzimos, ainda nesta aula, outras atividades que pudessem explorar a estrutura composicional e o estilo do texto dramático escrito.

Primeiramente, solicitamos que alguns alunos fizessem a leitura em voz alta da cena 17, do texto "O Vilarejo". De modo espontâneo, cada um escolheu sua personagem; na primeira fala, um dos alunos procedeu à leitura das rubricas e, no mesmo instante, grande parte dos alunos o repreendeu, dizendo que aquilo que estava entre parênteses não podia ser lido em voz alta. Assim, questionamos, junto aos alunos, qual era a utilidade daquelas indicações - denominadas rubricas. Eles responderam que serviam para "mostrar o que tem 
que fazer". Registramos, então, no quadro de giz, os tipos de rubricas existentes no texto dramático escrito e explicitamos suas funções correspondentes (HELBO, 1989):

- Rubricas cênicas - descrevem o cenário.

- Rubricas de interpretação - indicam o sentimento ou a emoção da personagem (como se deve falar).

- Rubricas de movimento - revelam a ação, a direção do olhar, o gesto ou a posição da personagem no palco (o que se deve fazer).

Com a finalidade de promover a correlação entre aquilo que os alunos assistiram/ouviram no teatro com aquilo que podiam observar no texto escrito, conduzimos a busca de exemplos dos tipos de rubricas mencionados. Procuramos, inicialmente, as rubricas cênicas:

\footnotetext{
Rubricas cênicas

É noite. Sentado no banco da praça, Jorge toca seu violão. Dona Marilda canta e Juquinha dorme em seu colo. No canto da cena, deitado em um pedaço de jornal, Heitor dorme. Jorge toca a música "Vilarejo" e Dona Marilda canta.
}

A indicação cênica selecionada pelos alunos retoma o início da peça "O Vilarejo". Eles nos disseram que havia correspondência exata entre o que estava escrito no texto e aquilo que assistiram no teatro. Na sequência, buscaram um exemplo de rubricas de interpretação:

Rubricas de interpretação
SENHORITA VIOLETA (curiosa) - O senhor vai entregar flores pra
alguém?
JORGE (mistério) - E que alguém seria?
SENHORITA VIOLETA (brava) - E eu que sei!
JORGE - Não faz ideia?
SENHORITA VIOLETA - Ora, Jorge! Faça-me o favor!
JORGE - Quero a mais bela flor pra entregar a minha amada!


SENHORITA VIOLETA (desanimada) - Oh! Sim... Vou providenciar... "pra sua amada" (triste)

JORGE (insistente) - A mais bela flor!

Os alunos quiseram proceder à leitura dessa cena, para, segundo eles, imitarem o jeito de falar das personagens que haviam assistido/ouvido. A iniciativa dessa atividade foi reveladora, pois os alunos verificaram que a maneira de falar de cada personagem podia ser indicada pelo autor do texto dramático escrito. Com isso, os alunos puderam concluir que as rubricas têm por função orientar o ator no momento da representação, isto é, o modo como ele “deve representar". Para finalizar, os alunos procuraram no texto dramático escrito exemplos de rubricas de movimento:

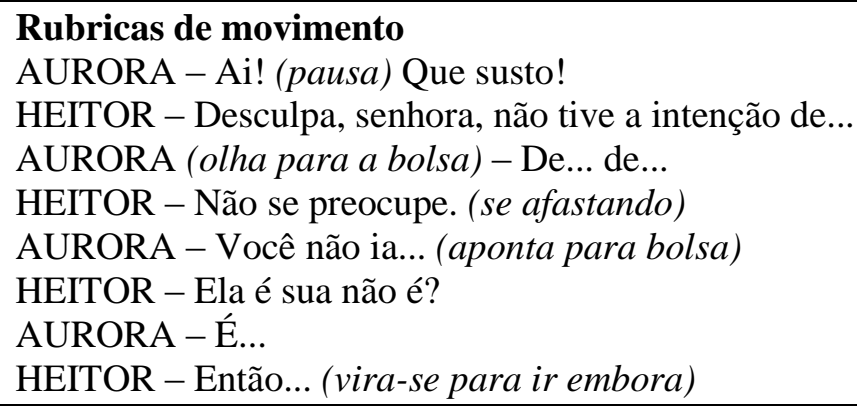

Esse trecho selecionado pelos alunos revela o momento em que as personagens Heitor e Aurora se encontram pela primeira vez. Os alunos recontaram detalhadamente as ações da cena e constataram que elas estavam descritas nas rubricas do texto escrito.

Com isso, pudemos evidenciar aos alunos que o texto dramático escrito tem por estrutura o diálogo e a descrição (UBERSFELD, 2010). O diálogo é representado pelas falas das personagens, e a descrição, pelas rubricas. Em nossa sequência didática, a discussão em torno das rubricas priorizou a comparação entre $\mathrm{o}$ texto escrito $\mathrm{e}$ o texto oralizado/representado, isto é, o importante papel que elas cumprem no texto escrito, ao projetarem a possibilidade da interpretação no palco. Na proposta aqui assumida, essa relação pôde se concretizar de forma completa em razão de os alunos terem tido acesso às duas modalidades do texto dramático "O Vilarejo": o texto oralizado/representado e o texto escrito. 
Ainda nesta aula sugerimos que os alunos observassem a pontuação do texto escrito: o uso das reticências, do ponto de exclamação, do ponto de interrogação e da vírgula (especialmente para marcar o vocativo). Orientamos os momentos do texto em que o uso desses sinais aparecia, e explicamos, por exemplo, o uso das reticências para indicar pausa (Exemplo 1) ou continuação da fala por outra personagem (Exemplo 2):

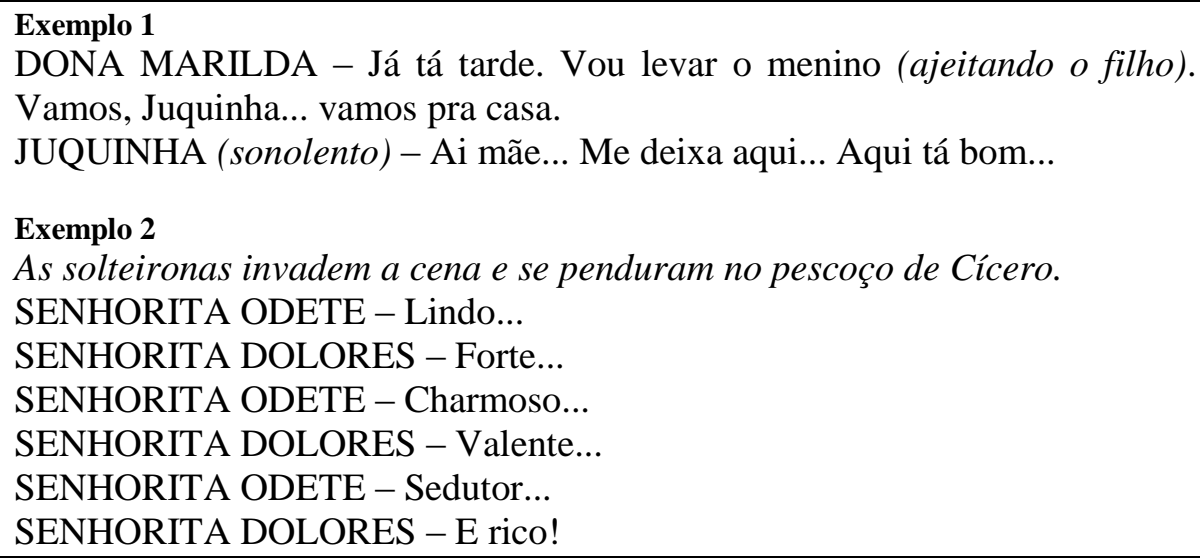

Observamos, também, o uso do ponto de interrogação, de exclamação e da combinação dos dois, para indicar, respectivamente: "uma pergunta", "uma fala surpresa" e "uma fala curiosa" (Exemplo 3). Além disso, ressaltamos o uso de mais de um ponto de interrogação para assinalar "uma fala indignada" (Exemplo 4) e o emprego da vírgula, para isolar o vocativo, "Dona Marilda" (Exemplo 4).

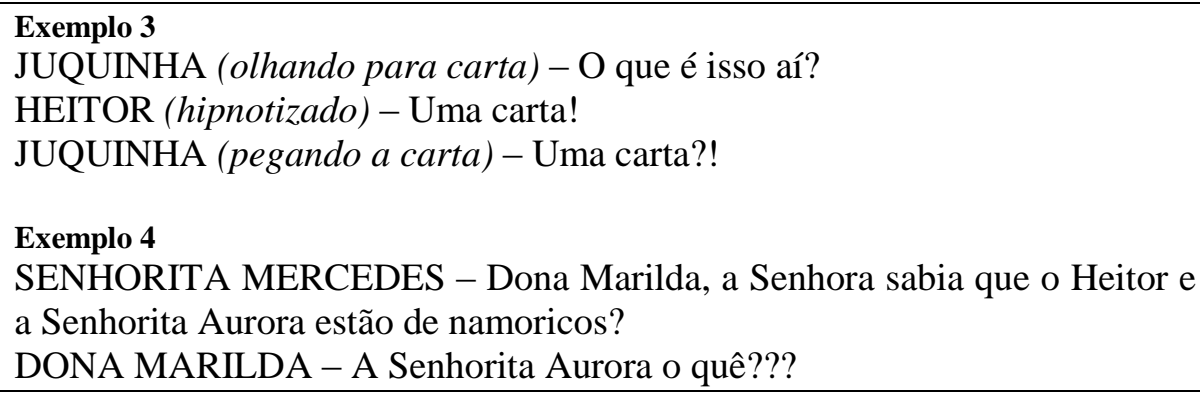

A realização dessa atividade mostrou-nos, como assegura Mendonça (2005), que a pontuação surge, na interface entre a fala e a escrita, como um dos recursos de que o falante dispõe para construir o sentido no texto escrito. Assim, entendemos que os sinais de 
pontuação empregados no texto dramático escrito relacionam-se à entonação e, principalmente, à intenção de cada personagem - estabelecendo aí, novamente, a relação entre as modalidades falada e escrita da língua. Em outras palavras, para além do que signifiquem esses sinais na gramática normativa, consideramos que o gênero texto dramático escrito toma a pontuação como um dos aspectos que determinam seu estilo, para construir os sentidos e as maneiras de se ler/falar/interpretar.

Para finalizar a aula, indicamos os alongamentos de vogais, outro recurso gráfico de que o texto escrito se utiliza para expressar conteúdos que o texto oralizado/representado exprime pela entonação, conforme asseguram os estudos de língua falada no Brasil, (FÁVERO; ANDRADE; AQUINO, 2002). Selecionamos três falas de o "O Vilarejo" que evidenciam o uso desse recurso e que apontam, novamente, para a correlação entre texto dramático escrito e texto dramático oralizado/representado (Exemplos 5, 6 e 7).

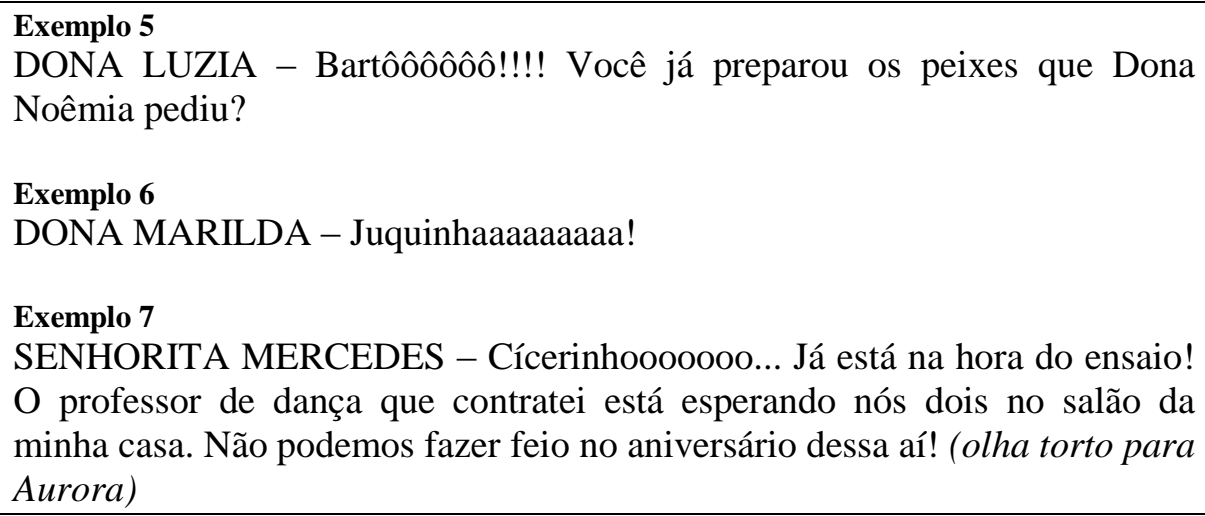
O professor de dança que contratei está esperando nós dois no salão da minha casa. Não podemos fazer feio no aniversário dessa aí! (olha torto para Aurora)

Nesse exemplo, os alunos retomaram a maneira como as personagens pronunciaram os nomes "Bartô", "Juquinha" e "Cícero" na apresentação teatral e verificaram, no texto escrito, como a autora procedeu a essa marcação. Segundo Barros (2001, p.74), “os sinais gráficos da escrita e a pontuação são utilizados para cumprir, no texto escrito, as funções de organizar, do ponto de vista argumentativo e afetivo-passional, as relações entre os interlocutores”. Assim, constatamos que, com a realização dessa atividade, os alunos puderam observar as relações estabelecidas entre as personagens da peça: a esposa, que solicitava a ajuda do marido a todo o momento (Dona Luzia e Seu Bartolomeu - "Bartô"); a mãe que, ao chamar a atenção do filho, gritava pelo seu nome de modo exagerado (Dona Marilda e Juquinha), e a moça do 
Vilarejo, que buscava convencer, delicadamente, o rapaz a ensaiar os passos de dança para a festa de aniversário (Senhorita Mercedes e Cícero).

As aulas seguintes foram dedicadas à realização de exercícios para fixação dos conteúdos até aqui abordados. Na Aula 04, os alunos receberam uma cópia de uma cena da peça "Flor do meu jardim ${ }^{53}$ ", também de nossa autoria, para que pudessem realizar atividades de fixação em torno da estrutura composicional e do estilo do texto dramático escrito. Contextualizamos, inicialmente, o recorte da peça e procedemos à leitura silenciosa da cena. Na sequência, efetuamos uma leitura coletiva em voz alta, permitindo a livre escolha de personagens. Os alunos manifestaram-se prontamente para leitura, houve "disputa" entre alunos, os quais verbalizaram: "eu quero ser a Rosa", "eu falei primeiro, professora", "professora, deixa eu ser a Justine?".

Destacamos o verbo "ser" nas falas dos alunos pelo fato de observar um desdobramento enunciativo decorrente dessa escolha lexical: alunos assumem o papel de atores, que assumem os papéis das personagens. Os alunos não solicitaram "ler", mas "ser" as personagens da cena apresentada. A situação instaurada na proposição dessa atividade revela uma particularidade do texto dramático, corroborada por estudiosos do teatro, como Stanislavski (2001[1936], p.43), para quem é preciso viver a personagem, “experimentando sentimentos que lhe sejam análogos".

Após a leitura coletiva da cena, os alunos responderam individualmente - e por escrito - as sete (07) questões relacionadas às características organizacionais do texto dramático escrito, elencadas a seguir:

1) O texto teatral conta uma história?

2) Quem conta a história?

3) Como é possível saber quem está falando em um texto como este?

4) Para que servem as indicações entre parênteses, que aparecem no meio da fala de uma personagem? Dê um exemplo.

5) E para que servem as indicações que aparecem entre as falas? Dê um exemplo.

6) Escolha uma fala em que a pontuação ajuda a sinalizar a forma como o texto deve ser lido. Explique sua resposta.

7) Por que o texto teatral apresenta rubricas?

${ }^{53}$ Cf. Anexo X. 
Com relação às três primeiras perguntas, todos os alunos apontaram para o fato de que o texto teatral é uma história contada pelas próprias personagens e que, para reconhecer quem estava falando, segundo eles, bastava observar o nome da personagem que se localizava à frente de cada fala.

Para as demais questões (4 a 7), selecionamos algumas respostas significativas que procuram ilustrar a apreensão, por parte dos alunos participantes desta pesquisa-ação, da estrutura composicional e do estilo do gênero texto dramático escrito. Com relação à questão 4, os alunos expressaram o entendimento da função das rubricas e exemplificaram-nas com trechos da cena lida anteriormente, conforme se observa nos Excertos 1 e 2, a seguir:
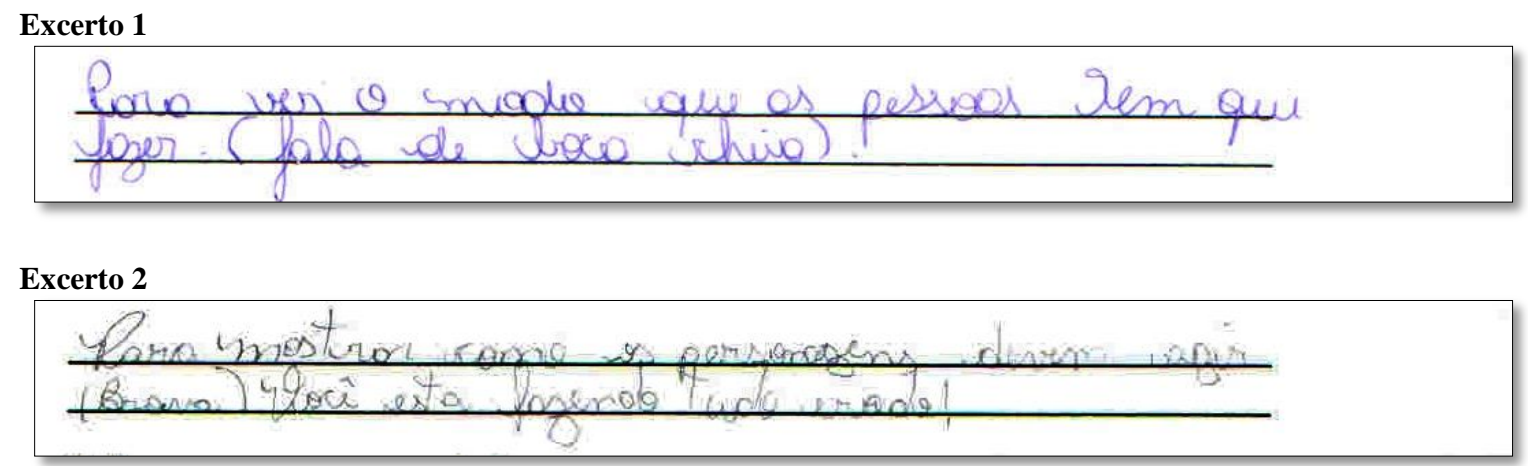

Para a questão 5, os alunos observaram a presença de rubricas cênicas, que indicaram, por exemplo, a mudança de cena (com a entrada ou saída de personagens) e a descrição do cenário, como se apresenta nos Excertos 3 e 4, a seguir:

Excerto 3

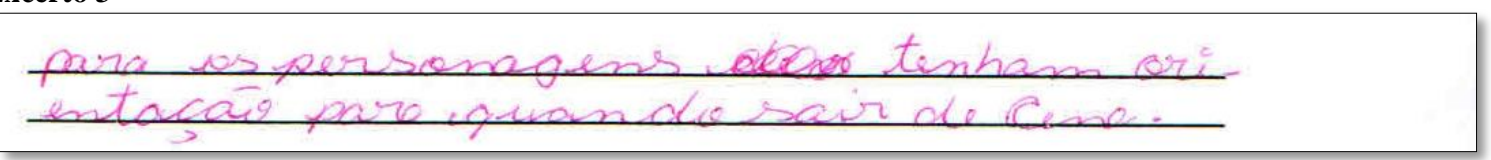

Excerto 4

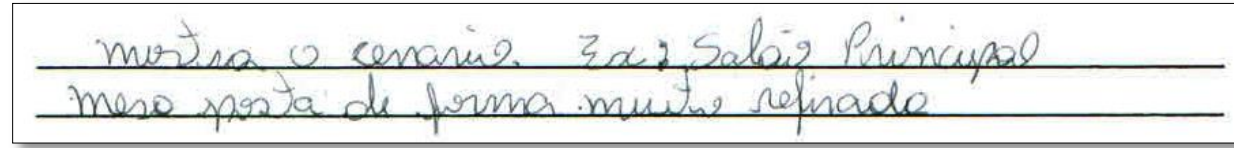


A questão 6 solicitava que os alunos buscassem na cena 4, da peça "Flor do meu jardim", um exemplo em que o uso da pontuação determinava a maneira de falar da personagem e, depois, justificassem a resposta. Assim, temos os Excertos 5 e 6 :

\section{Excerto 5}

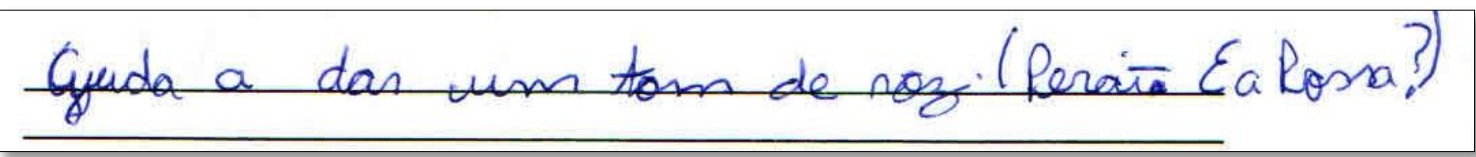

\section{Excerto 6}

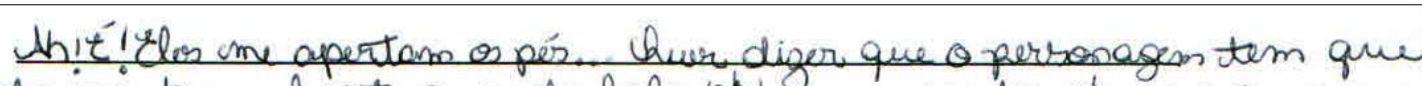
fala ive bem fart quando fale Ah! o ponto de resistinciós

é porque a hala cominera.

A última questão objetivava reforçar o papel das rubricas no texto dramático escrito.

Os alunos deviam explicitar o porquê de sua presença no gênero discursivo em estudo. Selecionamos duas das respostas:

\section{Excerto 7}

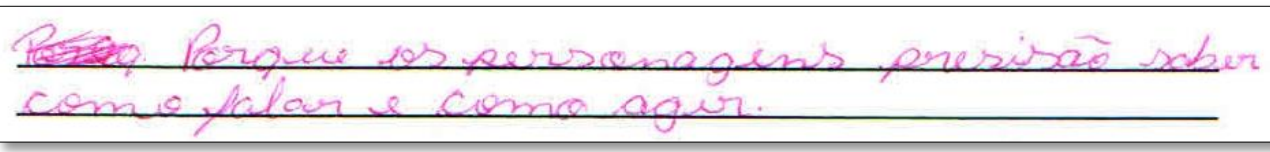

Excerto 8

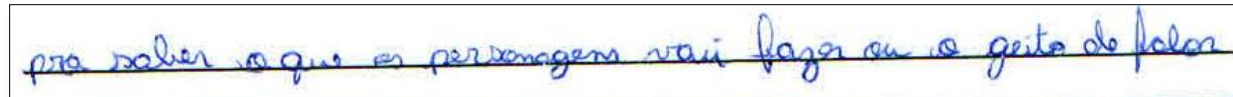

O levantamento das respostas permite-nos analisar que os alunos apreenderam a finalidade das rubricas (Excertos 1 e 2, 7 e 8), exemplificaram-nas (Excertos 3 e 4) e observaram o uso da pontuação (Excertos 5 e 6). Os resultados obtidos com o desenvolvimento dessa atividade permitem-nos afirmar que os alunos participantes desta pesquisa-ação apreenderam as características relacionadas à forma e ao estilo do texto dramático escrito. Compreendemos, então, que um Módulo didático voltado para apreensão de uma estrutura mais estável do gênero permite aos alunos, como também assegura Hila 
(2009), o reconhecimento dos aspectos composicionais, auxiliando-os no processo de recepção e produção escrita do próprio gênero.

Para finalizar a aula, propusemos uma atividade a ser realizada durante as férias de julho (três semanas), a saber: leitura de um livro de peças teatrais. Procedemos à distribuição dos livros para os alunos; algumas obras foram cedidas pela biblioteca da escola e outras emprestadas de nosso acervo particular. Ressaltamos que esse exercício não se constituiria avaliação, mas um incentivo aos alunos para que se familiarizassem um pouco mais com o gênero texto dramático escrito.

A aplicação dessa atividade vai ao encontro do posicionamento de Geraldi (2011[1984], p.61), para quem "não se deve tornar o ato de ler um martírio para o aluno - que ao final da leitura terá que preencher fichas, roteiros ou coisas parecidas". Nosso intuito, com essa atividade, também nessa direção - sem cobranças ou avaliações - foi ampliar as possibilidades de contato dos alunos participantes desta pesquisa-ação com o gênero discursivo em estudo, em seu meio de circulação convencional (livros, coletâneas), assim como o vivenciaram com a representação cênica (teatro da cidade).

Após duas aulas voltadas ao Módulo 2 - Produção de Leitura, descrevemos, na próxima seção deste capítulo, as atividades aplicadas aos alunos do $8^{\circ}$ ano $\mathrm{E}$ que caracterizam o Módulo didático de produção escrita do gênero discursivo texto dramático.

\subsubsection{Módulo 3 - Produção Escrita}

Para o desenvolvimento das aulas constantes deste Módulo, retomamos um dos propósitos de nossa sequência didática, qual seja: produzir coletivamente um texto dramático escrito, para representá-lo em um teatro da cidade aos alunos do turno da tarde do Colégio Rodrigues Alves. Tendo em vista esse objetivo, para dar início ao Módulo 3 - Produção Escrita, selecionamos duas atividades que se constituem uma espécie de aquecimento para a produção final: criação de rubricas para o diálogo entre duas personagens e elaboração da continuidade de uma cena teatral (Aula 05). 
Apresentamos, a seguir, as atividades aplicadas aos alunos participantes desta pesquisa-ação, que se caracterizam como um dos primeiros passos para a produção coletiva do texto dramático escrito. Na Aula 05, orientamos os alunos que fizessem, primeiramente, a leitura silenciosa do diálogo entre as personagens Rafaela e João, do texto "Era uma vez" que apresentamos a seguir, para que pudessem conhecer a história e as personagens envolvidas.

RAFAELA - Era uma vez...

\section{Era uma vez}

JOÃO - Pera aí! Era uma vez, que clichê!

RAFAELA - Ué!? Mas é uma história, tem que ter era uma vez...

JOÃO - Romeu e Julieta não começa assim...

RAFAELA - Você leu Romeu e Julieta por acaso?

JOÃO - Não...

RAFAELA - Então, como é que você sabe?

JOÃO - Eu li até a primeira página, mas depois eu enjoei...

RAFAELA - A história era chata?

JOÃO - Não, eu tava lendo no carro...

RAFAELA - Ah... Mas então, vamos brincar, Era uma...

JOÃO - Rafa!

RAFAELA - Tá bom, vou começar de novo, Era outra vez...

JOÃO - Rafa!

RAFAELA - Deixa eu continuar, por favor?

JOÃO - Tá bom...

RAFAELA - Então, era uma vez um menininho que não gostava de brincar com ninguém! (João começa a encenar a história) - Mas ele odiava brincar sozinho.

JOÃO - Eu odeio brincar sozinho! [...]

Na sequência, organizamos a sala em duplas e cada aluno optou por uma personagem para realizar a atividade que solicitava: "Escolha uma personagem, Rafaela ou João. Crie, nos espaços entre parênteses, rubricas que poderiam corresponder à interpretação ou à ação da personagem que você escolheu".

No decorrer da atividade, observamos que os alunos corresponderam ao comando, pois preencheram os espaços com rubricas que revelavam a maneira de falar das personagens e as ações por elas realizadas no momento da fala. Destacamos um trecho da atividade desenvolvida por uma das duplas, para ilustrar essa afirmação.

\footnotetext{
${ }^{54}$ Texto adaptado, disponível no site: www.oficinadeteatro.com.
} 


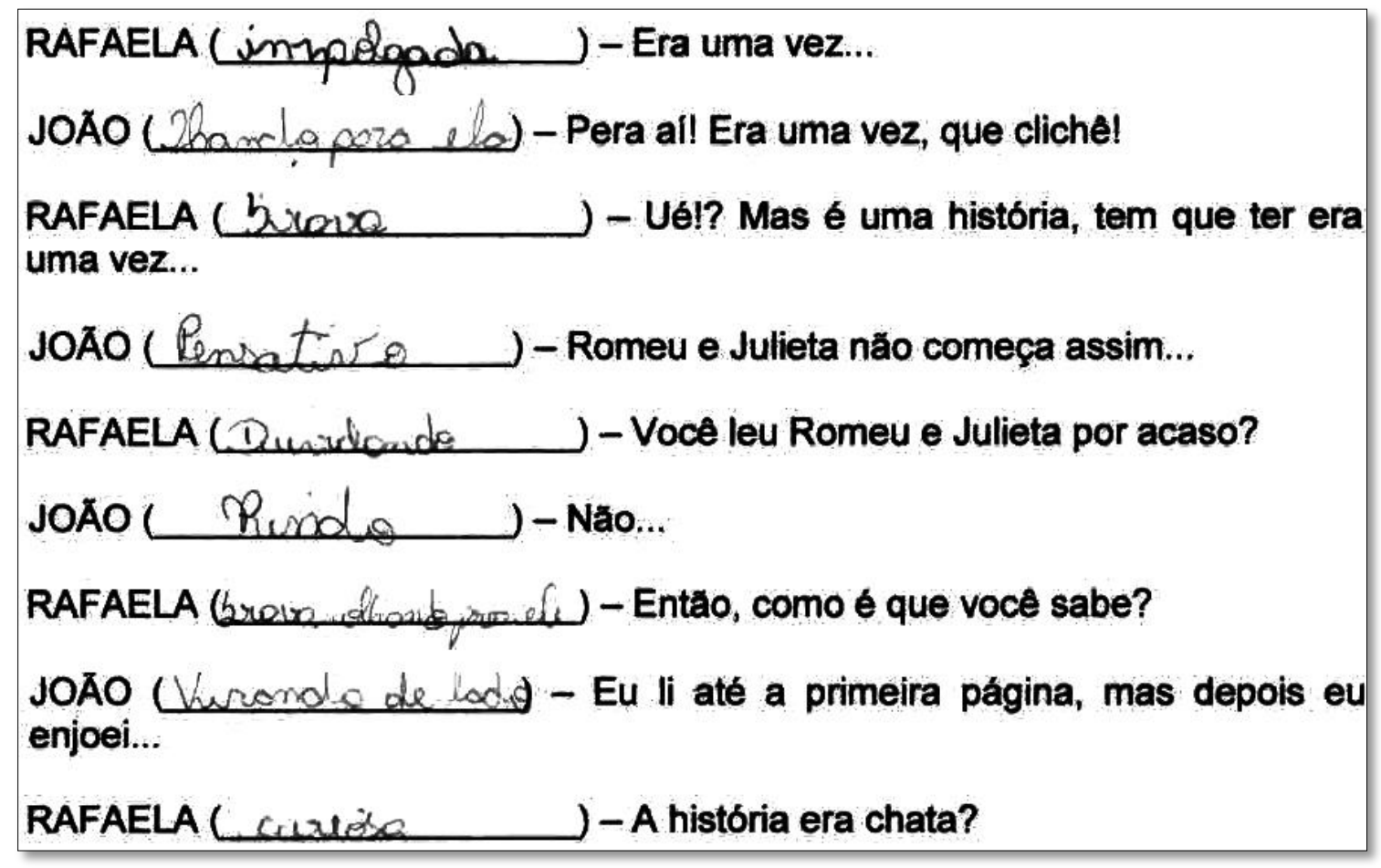

As rubricas de interpretação e de movimento, empregadas por esses alunos, condizem com as falas das personagens e com a interação propiciada pela história. Compreendemos, assim, como salienta Lopes-Rossi (2012), que toda escolha linguístico-textual e de estilo decorre dos aspectos sociocomunicativos do gênero discursivo e merece ser considerada no momento da produção escrita. A seleção lexical desses alunos revela, nesse sentido, um entendimento da dinâmica do texto dramático: é preciso marcar, por meio de rubricas, a maneira como as personagens agem ("olhando para ela", "olhando para ele", "virando de lado") e falam (“empolgada", "brava", "rindo", "curiosa"), para que se possa exaltar, também, o clima da história (intriga entre dois amigos).

Ao final do exercício de produção escrita de rubricas, propusemos que cada dupla fizesse a leitura em voz alta da cena "Era uma vez", respeitando as rubricas por eles mesmos sugeridas. A atividade foi bastante enriquecedora, pois os alunos puderam exercitar oralmente aquilo que escreveram, vivenciando, assim, sua produção textual. É válido destacar que alguns alunos gesticularam ao falar, direcionaram olhares, realizaram expressões faciais, empregaram entonações diferenciadas; uma dupla, inclusive, levantou-se para realizar a leitura. Acreditamos que exercícios como esse podem permitir aos alunos transitar, de 
maneira engajada e reflexiva, pelas multimodalidades que a natureza do gênero discursivo texto dramático convoca.

Nesta aula, os alunos deram continuidade a uma cena da peça "Flor do meu jardim", estudada na semana anterior, por meio de uma produção escrita. Assim, para que pudéssemos observar as dificuldades apresentadas pelos alunos, no que diz respeito, principalmente, à apreensão do gênero texto dramático escrito, elaboramos a seguinte atividade: "Dê continuidade à Cena 04, da peça "Flor do meu jardim", criando a Cena 05! Lembre-se de que, ao final da Cena 04, Rosa saiu, e a luz caiu. O que poderia acontecer depois disso? Qual diálogo seria possível? Quais personagens estariam nesta nova cena?”.

A atividade foi iniciada em sala de aula, mas muitos alunos não conseguiram/quiseram terminar suas produções e optaram por finalizar o texto em casa. Os alunos se mostraram muito reticentes em "ter de escrever" e perguntaram, inclusive, se valeria nota ou se realmente era obrigatório fazer a atividade. Observamos, nesse momento, que a produção de texto não se constituía uma atividade habitual para esses alunos, nem tampouco prazerosa, ao contrário, era algo distante do interesse deles. Em vista disso, optamos por deixar livre a entrega dessa atividade e observar a adesão espontânea dos alunos. Na aula seguinte, apenas cinco (05) alunos entregaram a atividade concluída, os demais, onze (11), justificaram que tinham se esquecido de fazer, que não tinham ideias para escrever, que era muito difícil ou, ainda, que "a preguiça tinha tomado conta".

Tal contexto levou-nos a propor um redirecionamento em nossa sequência didática. Esses alunos precisavam recuperar, de alguma forma, a confiança em sua produção escrita e reencontrar nela outros sentidos que não a obtenção de nota. Uma das decisões tomadas consistiu na busca por novas motivações que levassem os alunos a se engajarem, novamente, ao projeto pedagógico - isso se deu na fase do planejamento do texto dramático a ser produzido coletivamente.

Destacamos, a seguir, um exemplo de um dos alunos que finalizou a atividade proposta da criação de uma nova cena para peça "Flor do meu jardim". Do ponto de vista dos conteúdos estudados nas aulas anteriores, que retomam a organização do texto escrito, ressaltamos a escolha da cor de tinta diferenciada para marcar personagens, fala e rubricas e em alguns momentos do texto, observamos, também, a alternância do tipo de letra. 
(No vestiário todas intram imsera, com uum pouco de atroso, untra Rox)

Justive - Bom meniras, espero encontrar voces impecartis no baile!

Justirue - Rosa! (Falc assustacle) y trazada de novo?! careslina diz a Gïsela.

Carolirra - HaHA : Pelomenos está de sapatos agora.... (As dues comecem a rim.)

Justive - Esta' bem, estó bem! chegeec; Và se aprontar, que is baile is daqui imeia hora...

Justivie sai de cena.

(As macas a epressam e Logo terminam de secyeition, menos a 'riass').

RosA - Ah! nżo, nai encontro a 'drogà do meu vestido, e agora?! (fica desanimadz).

Gisela - Azar io sun!"; slbe com deboxe. Vamos CURSLIVE', is baile nos aguanda! 'saem de ana.' Justine compresse, valte pare ver rasa.

Justive - (ussustada) Dhe roupa lé essa Resa?! Para uum baile é preciso vestido Longa, uvoce com esse, esse mini vestido: Tenha modos... (Enfurecide)

Rexa - Oque posse fazer? (Aindando de um Lado pana outio tintando se calmar). (Quer mellor? A che so imen' verstido untaio. Justivie semdizer bada sai a nosice tambím. ( no saläo do baile toches se cyeitarn som senos pares,

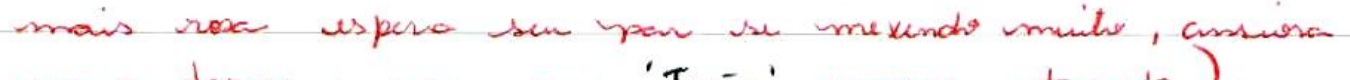
com a dcunce, cesur par 'Jožo' sempre atrosado). 


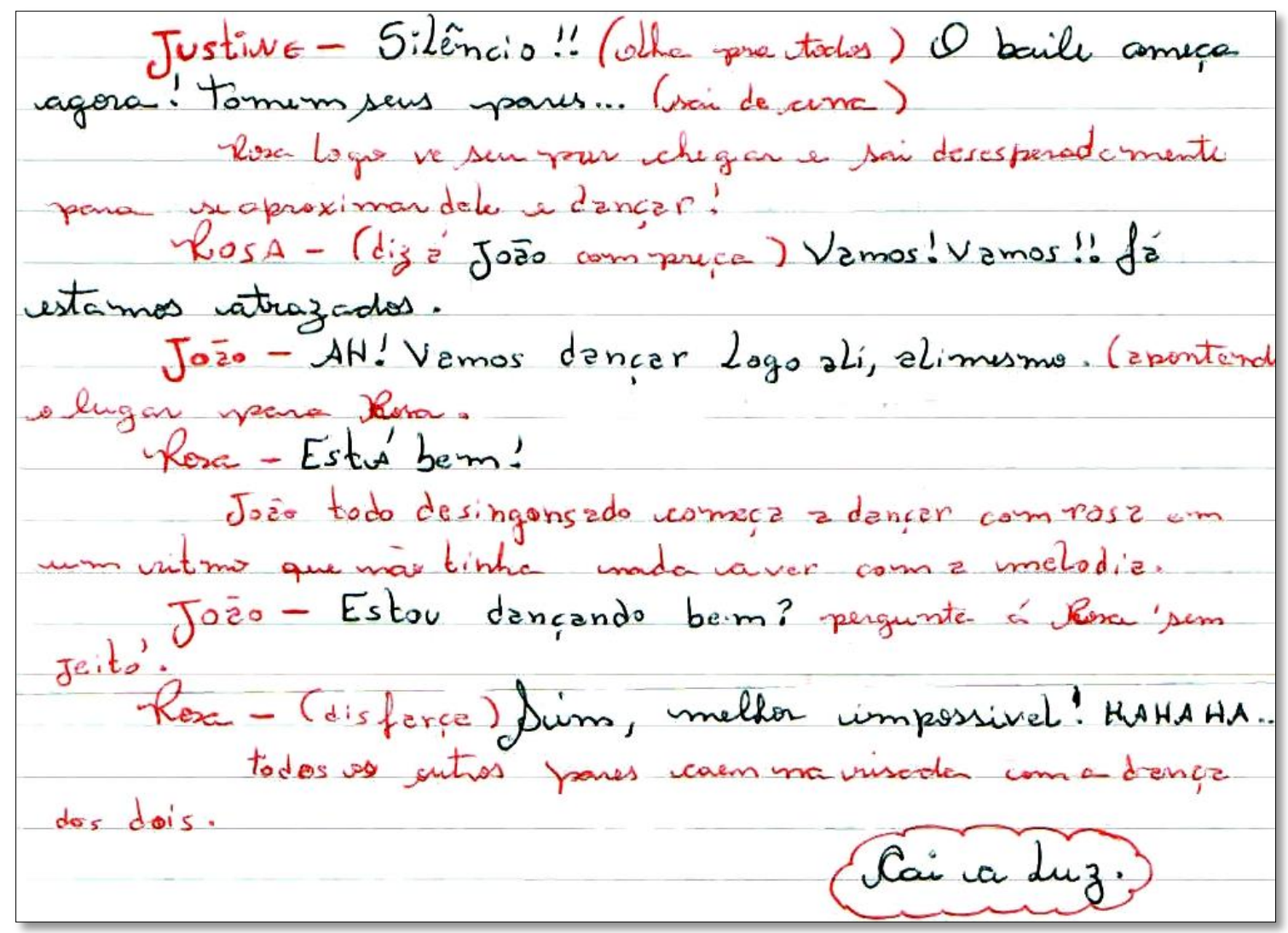

Uma das primeiras observações que é possível fazer diante desse texto é que há, sem dúvida, o reconhecimento visual do gênero, ou seja, não precisamos lê-lo integralmente para compreender que se trata de um texto dramático: as expressões "cena", no início do texto, e "cai a luz", ao final, ajudam a configurar a macroestrutura do gênero. Além disso, é possível verificar outras particularidades: nomes das personagens antecedidos de suas respectivas falas e emprego das rubricas entre parênteses.

A esse respeito, verificamos o uso dos três tipos de rubricas estudados no Módulo 2 Produção de Leitura: 1) Rubricas cênicas: "No vestiário todas entram em sena, com um pouco de atraso, entra Rosa" (sic), "no salão do baile todos se ajeitam com seus pares [...]"; 2) Rubricas de interpretação: "fala assustada", "fica desanimada", "enfurecida"; 3) Rubricas de movimento: "andando de um lado para outro tentando se acalmar", "olha pra todos", “apontando o lugar para Rosa”.

Constatamos, também, que o uso da pontuação no texto auxiliou a evidenciar, por exemplo, o susto da personagem Justine ao ver Rosa com uma roupa inapropriada para o baile, “Que roupa é essa Rosa?!", o pedido exacerbado de silêncio, "Silêncio!!” e a pergunta 
de Rosa “O que posso fazer?”. Já as reticências foram empregadas para indicar continuidade da fala: "que o baile é daqui meia hora...", "Tenha bons modos...".

Outro dado que nos chamou a atenção foi o uso de recursos gráficos específicos para dar ênfase às falas das personagens - recursos estes que não foram citados nas aulas anteriores: risadas em caixa alta, "HAHA", que parecem denotar um volume mais exagerado; aspas simples, para valorizar algumas palavras do texto, 'droga', 'meu', 'João' - neste último caso, até mesmo a mudança da cor da caneta; e repetição de palavras, "Está bem, está bem!", "Vamos, vamos!!” que, aliadas à pontuação, parecem reforçar o estado de ânimo das personagens.

Depreendemos, assim, que toda produção textual exige adequação ao gênero e necessita de uma competência linguístico-discursiva para cada situação comunicativa. Em outras palavras, no caso sob análise, ao utilizar marcações no texto dramático escrito que procuram representar a entonação ou a naturalidade da fala, o aluno revelou ter conhecimento de outros gêneros que também evidenciam essa condição, por exemplo, aqueles considerados por Marcuschi (2003) como materialmente escritos, mas conceitualmente falados (chats, bilhetes) e que se constroem a partir de uma natureza multimodal (notícias televisas, vídeos e fãs no Youtube), como exemplificam Rojo e Barbosa (2015).

Destacamos, ainda, o fato de que houve, nessa produção de texto, um cuidado especial para preservar as personagens originais da história "Flor do meu jardim" e suas características mais evidentes. A cena disponibilizada aos alunos apresentava quatro personagens: Rosa, a princesa do reino, avessa aos padrões da corte; Justine, a instrutora de etiqueta e bons modos; e Carolina e Gisela, duas meninas implicantes. Selecionamos, no texto sob análise, algumas falas que ratificam a manutenção desses perfis: “Ah! Não, não encontro a 'droga' do meu vestido, e agora?!" (Rosa), "Bom meninas, espero encontrar vocês impecáveis no baile!" (Justine), "HAHA! Pelo menos está de sapatos agora...” (Carolina) e “Azar o seu” (Gisela).

A temática também foi um dos aspectos conservados nessa proposta, apresentando, apenas, uma nova situação para as mesmas personagens: na cena anterior, Rosa chega atrasada à aula de etiqueta da senhorita Justine e, ainda mais, sem sapatos; a todo o instante é criticada pela instrutora; as colegas, Carolina e Gisela, riem de suas atitudes. Observamos, assim, na proposta de continuidade dessa cena, a consideração por esses detalhes, como o fato de Rosa estar novamente atrasada, mas, desta vez, com sapatos. Além disso, verificamos a 
permanência do humor na história; se na cena anterior Rosa aparece sem sapatos, nesta cena, ela dança de maneira descompassada com seu par.

Com relação às sequências textuais que compõem a cena, observamos a presença de diálogos e descrição - predominantes no texto dramático escrito. Um trecho, porém, parece recobrir a estrutura do discurso direto, usualmente empregado em textos da ordem do narrar. No início do diálogo, no momento de indicar a interlocutora da personagem Carolina, o aluno empregou "Carolina diz a Gisela" ao invés de proceder à composição específica do gênero: "CAROLINA - (para Gisela)".

Salientamos que a produção textual do aluno apresenta algumas inadequações ortográficas, como "deboxe" e "desingonçado". É válido mencionar que consideramos a questão ortográfica conteúdo importante na disciplina Língua Portuguesa, mas não a elegemos - neste projeto pedagógico -, como foco principal. Assim, também, para Dolz, Noverraz e Schneuwly (2004), a revisão ortográfica deve ser trabalhada somente na versão definitiva do texto.

O levantamento desses resultados permite-nos afirmar que houve, por parte deste aluno especialmente, apreensão das principais características que organizam o texto dramático escrito. Lembramos, porém, que a maioria dos alunos participantes desta pesquisa-ação não realizou o texto que se configurava um exercício de "aquecimento" para a produção final. Utilizamos, então, como estratégia para a próxima etapa da sequência didática, a formação de grupos, distribuindo para cada grupo, um dos cinco (05) alunos que efetuaram a produção individual, necessariamente, para motivar os demais alunos a produzirem.

Com base nisso, passamos à descrição da Aula 06, que se destinou ao planejamento geral da produção escrita do texto dramático, à definição do cenário, das personagens e do tema da história. Nesta aula, propusemos aos alunos o planejamento da produção coletiva do texto dramático escrito, que deveria ser livre de adaptações literárias; em outras palavras, eles deveriam inventar sua própria história, suas próprias personagens. Buscamos, com isso, explorar o processo criativo dos alunos, de modo a evidenciar, também, os temas subjacentes ao grupo escolar.

Conduzimos a atividade do planejamento, apresentando três possibilidades, a saber: 1) os alunos poderiam pensar em um cenário/situação que gostariam de atuar (floresta, velório, concurso de calouros, escola, festa de aniversário etc.) e, a partir disso, elencar as prováveis 
personagens que ali contracenariam; 2) os alunos poderiam pensar nas personagens que gostariam de interpretar (velha/o, criança, jovem, mocinha/o, vilã/o etc.), lembrando que deveriam contemplar o número total de alunos na sala; ou 3) os alunos poderiam escolher o tema/a mensagem da história (amizade, amor ao próximo, família, drogas, adolescência) e, assim, selecionar o lugar e as personagens que se adequariam a essas temáticas.

Diante das opções indicadas, os alunos se decidiram pelo cenário/situação e assinalaram a "festa de aniversário" como lugar em que ocorreria a história. O próximo passo constituiu-se da seleção das personagens: em primeiro lugar, definir, por exemplo, quem faria aniversário. Um aluno sugeriu que fosse a comemoração de 15 anos de irmãs gêmeas. A partir de então, os demais começaram a expor suas ideias quanto às personagens e suas principais características. Para eles, as irmãs deveriam ter um nome parecido, com a mesma inicial do nome da mãe, além disso, elas deveriam ter, também, uma irmã mais velha. Desta forma, os nomes escolhidos foram: Kássia (mãe), Keila e Kelly (gêmeas) e Karol (irmã mais velha).

Questionamos, então, onde seria realizada a festa de aniversário; eles disseram que na casa da família (na sala). Assim, sugerimos que houvesse mais personagens que completassem essa família - e que ela poderia ter um sobrenome também. Os alunos optaram pelo sobrenome Silva, segundo eles, "o mais comum de todos". Afirmaram, ainda, que deveria haver o pai das meninas e uma avó antiquada, pois "toda casa tem uma avó assim". Ao escolher os nomes dessas personagens, os alunos procederam à mesma caracterização da letra inicial, desta vez, empregando nomes similares: Joaquim (pai) e Joaquina (avó paterna).

Na sequência, os alunos assinalaram que a casa poderia ter uma empregada, já que, na concepção deles, a mãe das gêmeas deveria ser "dondoca". Assim, optaram por um nome que pudesse soar engraçado quando pronunciado; o nome eleito foi Socorro.

Escrevemos, então, no quadro de giz, o nome das personagens já indicadas e procedemos à explicação de que todos os alunos da sala deveriam ser contemplados: cinco (05) meninos e onze (11) meninas. A seguir, direcionamos a escolha das demais personagens da história: os convidados da festa.

Para os alunos, deveria haver amigas e amigos das aniversariantes, e amigas da irmã mais velha. Deveria ter, ainda, um menino de quem as irmãs gêmeas gostassem e uma menina invejosa, que causaria tumulto na festa ao chegar, sem ser convidada. Com isso, os alunos selecionaram os nomes das amigas, conforme seus gostos particulares: Camila (amiga da irmã 
mais velha), Rafaela e Fernanda (amiga das gêmeas). Indicaram, também, o nome Verônica, para a menina invejosa, porque, segundo eles, parecia com "vilã de novela" e o nome Lucas, para o menino de que as irmãs gostavam, por ser o nome do "paquera" da maioria das alunas da sala. Além disso, escolheram para os amigos os nomes com que mais se identificavam: Daniel, Gustavo e Leonardo e, para finalizar, elegeram a personagem Paty (irmã de Lucas), responsável por levar Verônica (a “intrusa invejosa”) para a festa de aniversário.

No decorrer dessa atividade, observamos que a sugestão para os nomes das personagens acompanharam, também, uma caracterização ou função específica para o desenvolvimento da história, em outras palavras, as personagens foram sendo escolhidas na projeção de acontecimentos prováveis para a peça teatral. Além disso, o momento inicial de planejamento da produção do texto escrito (determinação das personagens que comporiam a história) incentivou, de modo espontâneo, quem assumiria os papéis na encenação do texto, pois, sabendo que iriam atuar sua própria produção, os alunos exploraram uma prospecção para o palco; no conjunto de expectativas, disseram que alguns "combinavam mais com o perfil (de mãe, de avó)", ou que era “a cara dele(a), fazer esse papel” ou, então, verbalizaram antecipadamente o desejo de interpretar determinada personagem, "eu quero ser a Socorro", "eu quero ser uma das irmãs".

A euforia com que os alunos levaram essa etapa do planejamento do texto dramático escrito revelou-nos um comportamento bastante diferente daquele que apresentaram ao ter de escrever a continuidade de uma cena teatral. Eles manifestaram gostar de histórias e apresentaram uma cultura para contá-las, deram ideias, souberam buscar em seu imaginário e em suas experiências personagens e situações típicas. Entendemos, assim, que a oportunidade de compartilhar a criação do esboço da história com todo o grupo constituiu-se uma estratégia motivadora e significativa para a produção escrita que estava por vir.

Ainda nesta aula, os alunos escolheram o tema da história. A esse respeito, LopesRossi (2006) assevera que, ao definir o assunto e o esboço geral do texto, o aluno precisa considerar a função comunicativa do gênero discursivo e, a partir daí, definir os aspectos da temática que merecem ser abordados. Nessa direção, reiteramos aos alunos o objetivo final da produção escrita: representar o texto dramático para alunos do turno da tarde da escola, em um teatro da cidade. Isto levou-nos a propor ao grupo a seguinte reflexão: qual tema seria agradável apresentar para esse público? Quais assuntos lhes causariam interesse? A partir disso, os alunos optaram por retratar temas muito próximos à realidade (adolescente) deles e, 
especialmente, delas (das meninas da sala): "conversa sobre garotos", “inveja de outras meninas" e "briga entre irmãs". É válido pontuar que, nesse momento, os meninos pouco contribuíram. Entendemos que, por serem maioria, as meninas tomaram a frente das decisões e estabeleceram o tema da história. As aulas seguintes (07 a 14) foram dedicadas à produção coletiva do texto dramático escrito, conforme o levantamento das informações até aqui apresentadas.

$\mathrm{Na}$ Aula 07, orientamos a descrição das cinco (05) primeiras cenas da peça. Para tanto, escrevemos no quadro de giz o nome de todas as personagens envolvidas, de forma que os alunos pudessem eleger as situações que as trariam, uma a uma, para a história. Direcionamos os alunos na escolha de tais situações, informando, por exemplo, que deveria haver os preparativos para festa, que era preciso mostrar a expectativa das irmãs para o grande dia etc.

Todo o processo foi realizado de modo coletivo. Os alunos se dispuseram em círculo e, aos poucos, foram manifestando suas ideias. Procedemos, assim, à criação de sinopses para cada cena e resumimos, no quadro de giz, o que deveria conter cada uma delas. Apresentamos, a seguir, a descrição das cenas realizadas nesta aula:

Cena 01: Na casa da família Silva, a faxineira Socorro limpa e organiza a festa de 15 anos das irmãs gêmeas, Keila e Kelly, enquanto faz isso, ela reclama. Kássia, a mãe, e Joaquina, a avó, aparecem para agilizar a arrumação.

Cena 02: As irmãs gêmeas conversam sobre a expectativa da festa: escolha do vestido, decoração, comida, convidados. Elas falam/discutem sobre o Lucas.

Cena 03: Chega o pai, Joaquim, com o bolo da festa. A mãe, Kássia, confere a encomenda e verifica o sabor, descobre que o pai se enganou e trouxe um bolo "coco com maçã". Eles discutem.

Cena 04: Camila, a amiga das gêmeas, aparece para ajudar as irmãs a se arrumarem. Ela é amiga de Lucas e conta o que ele comprou de presente, mas não diz para quem é cada presente: um urso de pelúcia com um coração vermelho e um perfume. As irmãs brigam. Conflito e muita expectativa.

Cena 05: Os convidados começam a chegar: Fernanda e Rafaela. Pai, mãe e avó estão na sala. Karol recebe as convidadas. Elas comentam sobre Verônica, o fato de ela não ter sido convidada para festa.

Consideramos que o planejamento das cenas que compõem um texto dramático escrito constitui-se parte determinante para os resultados da produção final. Em um projeto pedagógico que visa à produção escrita desse gênero discursivo, como este se apresenta, 
entendemos ser imprescindível contar com uma etapa como essa, para que os alunos consigam organizar as situações que devem ser apresentadas em cada cena, as personagens envolvidas, a marcação da entrada/saída de novas personagens ou da mudança de cenário. Ao finalizarmos a descrição das cenas, um dos alunos comentou, "Nossa, mas assim vai ser muito mais fácil escrever!”.

Nas aulas seguintes (08 a 12), os alunos realizaram a produção escrita das cinco (05) primeiras cenas do texto dramático, obedecendo ao seguinte processo: divididos em pequenos grupos, os alunos recebiam uma folha personalizada para produção das cenas ${ }^{55}$, que continha os seguintes campos a serem preenchidos: data, grupo de dramaturgos - em que se deveria colocar o nome dos alunos -, título da cena, descrição geral da cena e observações feitas em sala (fase do planejamento da produção escrita). De posse desse material, iniciaram a produção das primeiras versões (Imagens 17 e 18):
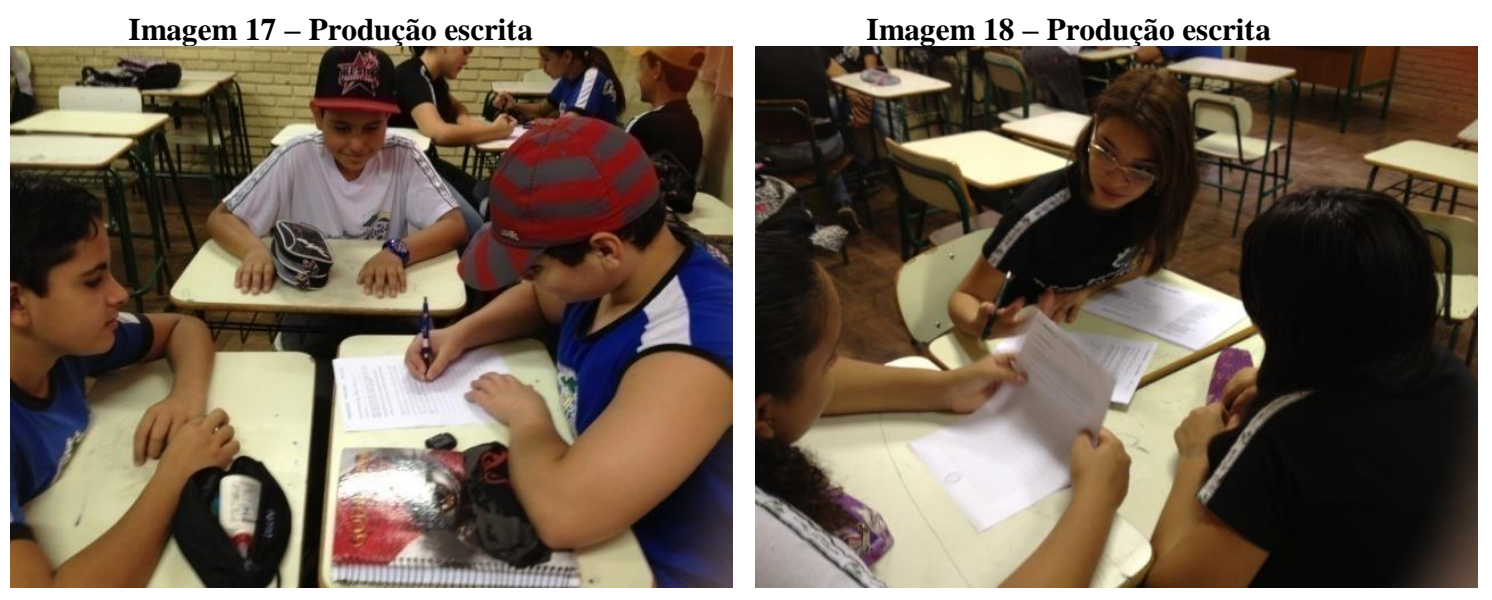

Conforme consta do quadro-síntese da sequência didática aplicada nesta pesquisa-ação - apresentado no início deste capítulo -, após produzirem as primeiras versões das cenas ${ }^{56}$ (01 a 05), os alunos realizaram a revisão colaborativa ${ }^{57}$. Lopes-Rossi (2011) salienta que, em projetos de produção escrita de gêneros discursivos, a revisão colaborativa prevê a opinião dos colegas quanto ao conteúdo e organização geral do texto, constituindo-se uma atividade desejável não apenas como contribuição à produção, mas também como um exercício de leitura crítica do gênero.

\footnotetext{
${ }^{55}$ Cf. Anexo XI.

${ }^{56}$ As primeiras versões de todas as cenas da peça encontram-se no Anexo XII.

${ }^{57}$ A revisão colaborativa realizada com todas as cenas da peça localiza-se no Anexo XIII.
} 
Para efetuarmos a correção colaborativa das cenas, cada aluno recebeu uma cópia de cada cena produzida. Na sequência, procederam à leitura em voz alta, a fim de que pudessem observar a adequação ao gênero (estrutura composicional e estilo). Nesse processo, os alunos indicaram, também, se as falas condiziam com as características das personagens citadas na etapa do planejamento.

Por último, orientamos a observação/correção coletiva do texto quanto à grafia: o uso adequado de algumas letras "brasso" (braço), "anciosa" (ansiosa), "erado" (errado); a acentuação gráfica em algumas palavras "maça” (maçã), “ironica” (irônica); a utilização de maiúsculas para nomes próprios "lucas" (Lucas) e "joaquim" (Joaquim) e no início de frases “Como? Eu ouvi direito? não pode ser! maçã com coco?” (Não; Maçã). Orientamos também a observação/correção da sintaxe/coesão: o uso adequado da concordância verbal "Kelly e Keila cortam o bolo e percebe que tem algo diferente" (percebem), "As duas vão para a mesa de presentes e pega o que Lucas deu", (pegam) $)^{58}$.

Na Aula 12, conduzimos a produção das sinopses contendo a descrição das últimas cenas da peça. Desta vez, escrevemos no quadro de giz o nome das personagens que não haviam aparecido na história, porque, desse modo, os alunos poderiam pensar em como lhe dar continuidade, atribuindo fala àqueles que ainda não tinham sido contemplados. Direcionamos os alunos, também, para que observassem a manutenção da coerência no desfecho da história, tendo em vista as situações que já haviam sido reveladas nas primeiras cenas: o que acontecerá quando as meninas souberem que o bolo é de maçã com coco? Para quem é o urso de coração que Lucas comprou? Será que Verônica aparecerá na festa sem ser convidada?

O planejamento das cenas foi, novamente, realizado de modo coletivo e, mais uma vez, recorremos à elaboração das sinopses para cada cena, escrevendo-as no quadro de giz. A seguir, indicamos a descrição das últimas cenas, propostas pelos alunos:

Cena 06: Estão em cena Karol, Fernanda e Rafaela, sentadas à mesa. Joaquina e Joaquim servem salgadinhos às meninas. Toca campainha. Daniel, Gustavo e Leonardo estão à porta. Joaquina os atende. Eles perguntam onde podem deixar os presentes, cumprimentam as meninas e sentam em outra mesa.

\footnotetext{
${ }^{58}$ Os exemplos foram retirados do Anexo XIII.
} 
Cena 07: Os convidados estão sentados à mesa: meninos - Gustavo, Daniel e Leonardo; meninas Rafaela, Fernanda e Karol. Joaquina e Joaquim servem os meninos. Toca a campainha. É Lucas. Karol corre para avisar as irmãs.

Cena 08: Os convidados estão sentados à mesa: meninos - Gustavo, Daniel, Leonardo e Lucas; meninas - Rafaela e Fernanda. Toca a campainha. É Pat, irmã de Lucas, acompanhada de Verônica. Joaquina pede para Lucas atender. Ele fica surpreso com a chegada da irmã, que trouxe Verônica. Os convidados cochicham. Fernanda começa uma discussão.

Cena 09: Kássia chama os convidados para os parabéns. No momento de cortar o bolo, as gêmeas descobrem que o sabor é maçã com coco. Elas discutem com o pai. Karol se lembra do "com quem será". Mas não tem como as duas ficarem com o Lucas. Então, elas decidem abrir os presentes. Cada uma recebe um par de brincos. Elas ficam desanimadas e olham para Camila. Verônica dá risada.

Cena 10: Socorro limpa a festa e come um pedaço do bolo.

Nas aulas seguintes (13 a 14), os alunos realizaram a produção escrita dessas cenas, obedecendo ao mesmo método de produção coletiva e revisão colaborativa. Ao final de todo esse processo, os alunos decidiram o título do texto "Festa de Aniversário", segundo eles, esta opção criaria expectativa e certa curiosidade no público. Quanto ao título das cenas do texto dramático produzido, temos: Cena 01 - A faxina para a festa, Cena 02 - Ele gosta de mim, Cena 03 - O sabor da briga, Cena 04 - O presente de Lucas, Cena 05 - A chegada dos convidados, Cena 06 - A chegada dos meninos, Cena 07 - A chegada de Lucas, Cena 08 - A chegada da Verônica, Cena 09 - A decepção e Cena 10 - O fim da festa.

Observamos que os alunos empregaram várias estratégias e estabeleceram focos diversificados para atribuição dos títulos: referente ("a faxina”, "o presente”), conteúdo ("ele gosta de mim", “a decepção") e sequência dos fatos (“a chegada...", “o fim da festa”). Salientamos, ainda, o título "O sabor da briga" que, de modo criativo, indica o duplo sentido da cena: o casal briga por conta do sabor "ingrato para adolescentes" do bolo da festa de aniversário: coco com maçã. Entendemos a importância do emprego de títulos (na produção escrita escolarizada do gênero) para ajudar a sintetizar o acontecimento de cada cena, auxiliando o aluno-dramaturgo na organização dos fatos.

Destacamos alguns fragmentos das primeiras versões do texto dramático produzido pelos alunos do $8^{\circ}$ ano $\mathrm{E}$ que revelam as tentativas de apreensão da estrutura composicional do gênero, conforme observamos no início da primeira versão da Cena 01, a seguir: 


\section{Leconzo inta en sena varrendo a sala}

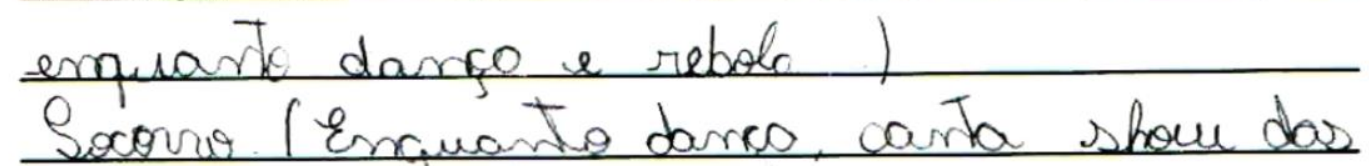

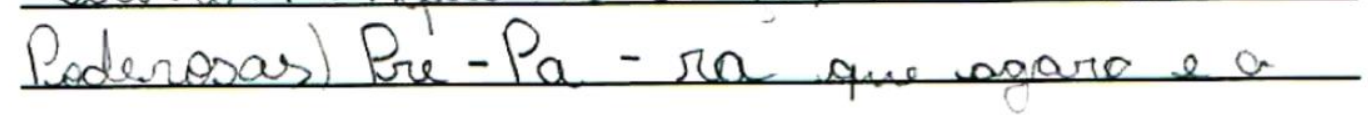

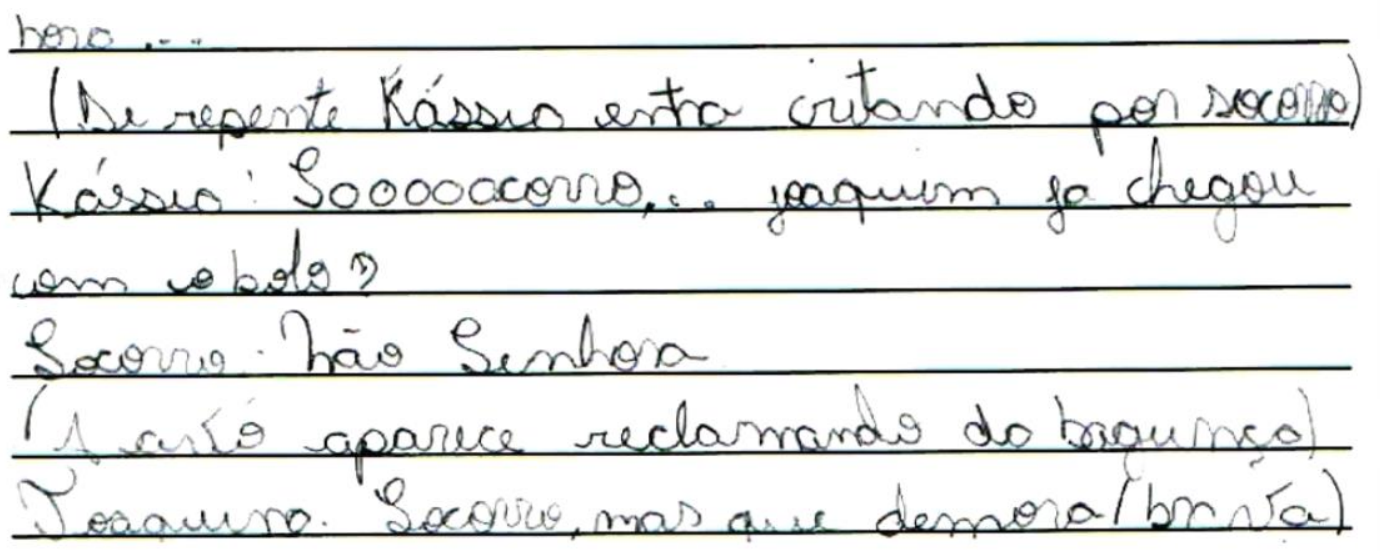

Nessa cena, é possível verificar, por exemplo, o emprego da rubrica de movimento, intercalada na fala da personagem, com o uso dos parênteses para indicar o que ela deve fazer enquanto fala: "Socorro entra em cena varrendo a sala enquanto dança e rebola". Houve, também, o emprego deslocado da rubrica de interpretação "brava", localizada após a fala da personagem Joaquina: "Socorro, mas que demora (brava)". O mesmo ocorre no início da Cena 04, a seguir:

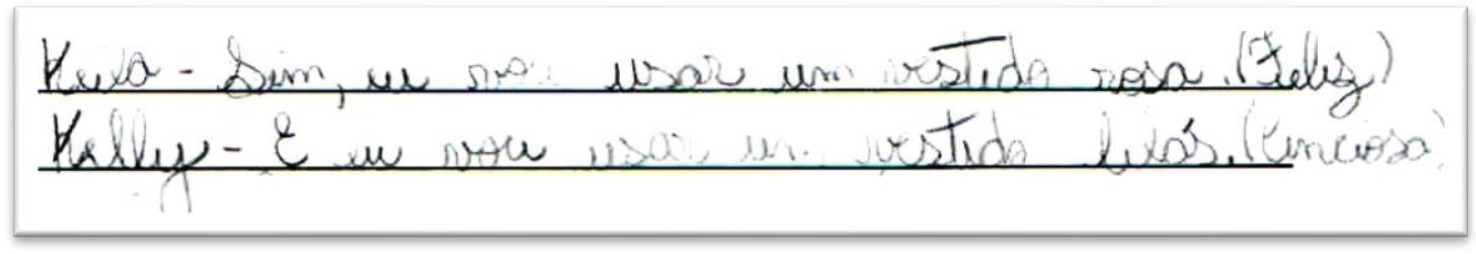

Nesses dois casos, a posição dos parênteses pospostos à fala da personagem aproxima-se das práticas de escrita de outros gêneros que circulam na escola, em que os parênteses são empregados com função explicativa. Observamos, assim, que as tentativas de 
escrita desse "novo" gênero fizeram emergir, também, relações intergenéricas. Na correção colaborativa do texto, os alunos puderam verificar "a maneira de ser do gênero", e compreender como funcionava seu mecanismo de escrita e, aos poucos, permitiram-se atuar como produtores de texto dramático.

Após dez (10) encontros dedicados ao Módulo 3 - Produção Escrita, com duração total de $11 \mathrm{~h} / \mathrm{a}$, passamos a trabalhar com os alunos do $8^{\circ}$ ano E atividades voltadas para a produção oral e multimodal do gênero discursivo texto dramático, que constituíram o quarto Módulo de nossa sequência didática, descrito a seguir.

\subsubsection{Módulo 4 - Produção Oral e Multimodal}

Após as revisões colaborativas do texto escrito, efetuadas nas aulas anteriores, procedemos à digitação do material completo produzido pelos alunos do $8^{\circ}$ ano $\mathrm{E}$ (peça teatral "Festa de Aniversário"59), a fim de disponibilizar cópias aos alunos, para que pudessem utilizá-las como objeto de estudo e apoio à encenação e às demais atividades a serem propostas na sequência didática. As próximas aulas (15 a 21) foram dedicadas às atividades que compõem o Módulo 4 - Produção Oral e Multimodal, dentre as quais se destacaram: leitura dramática, leitura oralizada com vistas à construção da personagem, marcação de cenas e ensaios.

A Aula 15 iniciou-se com a entrega do texto digitado aos alunos, que se manifestaram satisfeitos com a produção, ao dizerem: "nem parece que foi a gente que fez", "olha como ficou bonito", "que legal!". Na sequência, dispusemos as cadeiras em círculo e explicamos a atividade a ser realizada: leitura dramática, registrada na Imagem 19, a seguir:

${ }^{59}$ Cf. Anexo XIV. 


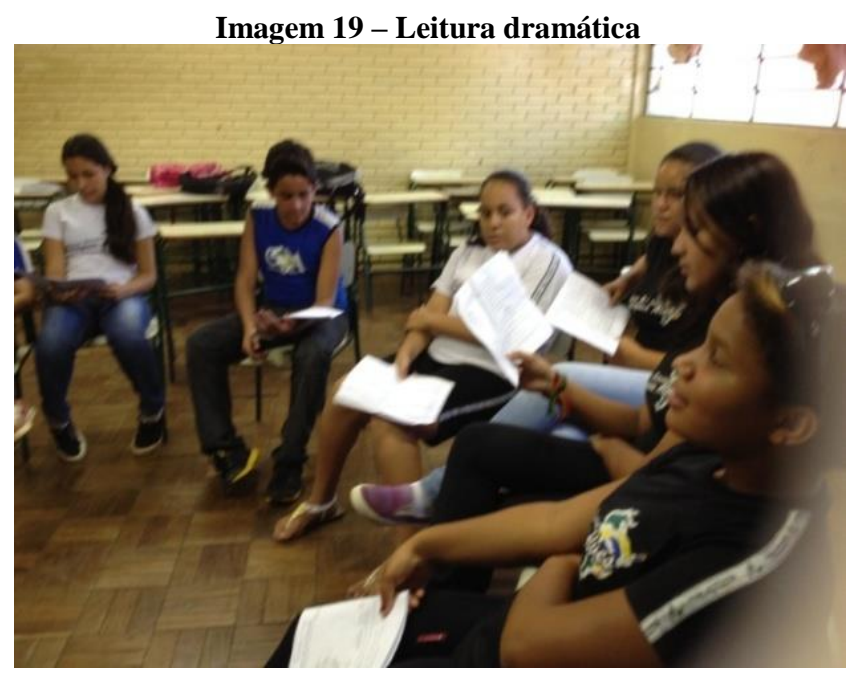

A leitura dramática constitui uma série de tentativas de dizer um mesmo texto (RYNGAERT, 1995); comum em exercícios do universo teatral, essa ação particularizada de ler privilegia uma aproximação dos atores com a materialidade linguística, em seus primeiros contatos com a produção oral do texto escrito.

A atividade junto aos alunos do $8^{\circ}$ ano $\mathrm{E}$ ocorreu da seguinte maneira: respeitando o sentido anti-horário da disposição dos alunos, cada um tinha por função ler apenas uma fala do texto dramático "Festa de Aniversário" de um modo diferenciado, conforme ordenação apresentada nos itens a seguir. Encerrada a participação de todos os alunos no tipo de leitura solicitada nessa etapa, recomeçava um novo tipo de leitura do ponto exato em que o último aluno havia parado. Com a utilização dessa dinâmica, os alunos puderam ler o texto completo mais de uma vez, coletivamente e de diversas maneiras.

Ressaltamos que os tipos de leitura dramática utilizados nessa atividade e até mesmo as nomenclaturas e suas descrições são fruto de nossa experiência em oficinas de teatro já ministradas para atores e não-atores, em contextos variados, dentro e fora do ambiente escolar. Apresentamos, a seguir, a ordenação das modalidades de leitura efetivadas nessa aula:

- Leitura branca: leitura que exige mínima expressividade, não obedece aos sinais de pontuação, ignora qualquer intenção da personagem; espécie de leitura sem emoção, sem esforço. 
- Leitura devagar: leitura silábica em que se aproveita a articulação da boca, da língua e da face como um todo; leitura lenta no sentido estrito da palavra.

- Leitura rápida: leitura similar à fala de um locutor de futebol (rádio), modo de ler as palavras ligeiramente.

- Leitura chorando: leitura chorosa, triste, melancólica.

- Leitura rindo: leitura que faz do texto uma piada constante, palavras entrecortadas por risadas tímidas ou escandalosas, respiração audível; leitura risonha, engraçada.

- Leitura cantando: leitura que faz do texto versos de uma canção; imprimem-se curvas melódicas, ritmos diversos.

- Leitura sussurrando: leitura em pequenos sopros, em tom baixo; as palavras se transformam em segredos que devem ser ditos de forma muito cautelosa.

- Leitura com sono: leitura entrecortada por bocejos, voz cansada; pausas que sinalizam sonolência.

- Leitura com voz diferenciada: leitura que modifica a voz natural e sugere uma alteração no tom, estilo, modulação; emprego de timbre diferente do convencional.

- Leitura com sotaque: leitura que retoma os dialetos regionais, possibilidade de brincar com a língua falada em outras localidades.

- Leitura exagerada: leitura que valoriza de forma acentuada as palavras, ênfase nas possíveis intenções das personagens, leitura expressiva por excelência; possibilidade de se levantar, gesticular.

Salientamos que os tipos de leitura mencionados buscam familiarizar os alunos com o texto dramático, no sentido de prepará-los para a representação cênica e, mais amplamente, para a realização de práticas de linguagem orais e multimodais.

Os alunos iniciaram, então, a atividade com a leitura "branca" e seguiram a ordenação descrita até finalizarem com a leitura "exagerada". O exercício provocou uma espécie de desconstrução dos sentidos do texto, já que, em cada nova leitura, novas emoções/entonações eram exigidas; o objetivo da leitura recobriu, neste momento, não necessariamente $o$ quê estava sendo dito, mas como cada um dizia o texto em cada etapa da leitura. Destacamos, também, que essas diferentes modalidades de leitura apontaram para um cuidado especial com 
as palavras do texto e, mais amplamente, com todo enunciado, seja na dicção, inflexão de voz, volume ou ênfase empregadas.

Observamos, ainda, que o exercício foi realizado de modo bastante descontraído, como comprovam dois segmentos da aula em que registramos um vídeo dos alunos efetuando as leituras "lenta" e "rindo" 60 . A participação dos alunos foi bastante positiva; mesmo que alguns se mostrassem resistentes à atividade, os demais "cobravam-lhe" a realização da leitura, motivados pelo anseio de chegar a sua vez de ler. Por vezes, houve, também, a ajuda mútua entre os alunos, por exemplo, casos em que alguns perdiam a sequência das falas, e os que estavam próximos ajudavam-no a encontrar o segmento que deveria ser lido. Ressaltamos a torcida pela leitura do colega, pois houve momentos em que alguns disseram não conseguir realizar determinado tipo de leitura, e os demais o incentivavam a tentar.

No decorrer da aula, as repetidas leituras fizeram com que os alunos pudessem experimentar a produção oral do gênero - ao brincarem com as possibilidades de verbalizar as falas das personagens - e, particularmente, estreitar a relação com o texto que iriam encenar. Salientamos, também, que a leitura dramática pôde viabilizar um caminho possível para memorização das falas do texto dramático, exercício que, para eles, parecia difícil, quando assistiram à peça "O Vilarejo" no teatro. Corrobora essa afirmação o fato de alguns alunos não acompanharem com os olhos o segmento destinado para os tipos de leitura indicados e, espontaneamente, interpretarem as falas com breve apoio do texto escrito.

Ao final dessa aula, solicitamos como tarefa para casa o estudo do texto dramático "Festa de Aniversário", com vistas à escolha da personagem. Dissemos que na próxima aula seriam definidos os papéis que cada aluno interpretaria na encenação. A expectativa tomou conta do grupo e alguns foram taxativos ao afirmarem: "eu quero ser o pai”, "eu só não quero ser a avó".

Dedicamos, assim, a Aula 16 para livre escolha das personagens. Dispostos, novamente, em círculo, cada aluno verbalizou sua escolha, revelando as personagens que desejava interpretar (como primeira e segunda opções) e também aquela personagem que não gostaria de assumir. Registramos as opções no quadro de giz; houve disputa de papéis por um lado, e papéis menos quistos, por outro. Conduzimos a situação com a apresentação da

\footnotetext{
${ }^{60}$ Cf. Anexo XV.
} 
proposta de uma leitura oralizada de alguns trechos do texto, possibilitando o revezamento entre aqueles que queriam interpretar uma mesma personagem.

Após as leituras, houve acordos e renúncias; os alunos, finalmente, decidiram-se. Os argumentos empregados voltaram-se, basicamente, ao desempenho oral (“ele leu melhor"), ao perfil do(a) aluno(a) (“ela combina mais com a avó”) e à afinidade com a personagem (“eu quero ser a amiga, porque gostei dela na parte da história que tem briga e porque sou meio briguenta também”).

A atividade seguinte constituiu-se do estudo do texto dramático, priorizando a compreensão da personagem escolhida. Solicitamos aos alunos que sintetizassem, utilizandose de um verbo, cada instante de participação de suas personagens e registrassem a palavra ao lado de suas falas. Essa sugestão de atividade recobre o método stanislavsquiano para atuação, o qual orienta para o fato de que cada objetivo da personagem deve trazer dentro de si a semente da ação, "o que quer que aconteça no palco, deve ser com um propósito determinado", pois no teatro, "toda ação deve ter uma justificação interior, deve ser lógica, coerente e real” (STANISLAVSKI, 2001[1936], p.65 e p.76).

Fala por fala, os alunos foram nomeando a ação que as definia. No momento em que Kássia (a mãe das aniversariantes) diz "Soooocorro!!! Joaquim já chegou com o bolo?”, a aluna procedeu à indicação do verbo "gritar", para a primeira frase, e "investigar", para a segunda. Acompanhamos a realização dessa atividade e orientamos a seleção de verbos, do ponto de vista de sua semântica. Verbos como "dizer", "falar", "perguntar", "afirmar" ou "responder" foram sendo substituídos, aos poucos, por "cumprimentar", “condenar", “duvidar", “contestar”, “desprezar”, por exemplo.

Pedimos aos alunos que, ao longo do projeto, estudassem as falas de sua personagem, com o intuito de compreender o contexto em que eram empregadas, no sentido de memorizar a sequência de ações e intenções que prevaleciam nas cenas, e não necessariamente ter por obrigação "decorar tudo". Avisamos, também, que iniciariam as marcações das cenas 01, 02, 04 e 10 nas próximas aulas. Desse modo, fizemos um acordo com o grupo: os alunos que assumiram as personagens constantes dessas cenas tinham o compromisso de não faltar à aula, estudar o texto em casa e lembrar-se de trazê-lo para a escola. Salientamos que nem todos os alunos atenderam a essas orientações; nas aulas seguintes, houve empréstimos de texto e substituição temporária de alunos-atores. 
Antes de iniciarmos a descrição das aulas destinadas à marcação das cenas e aos ensaios, pontuamos que, em meio ao desenvolvimento da pesquisa-ação, tivemos de lidar com a chegada de um aluno novo na turma. Esse aluno faltou aos primeiros nove (09) encontros do projeto pedagógico, sua participação iniciou-se na revisão colaborativa do texto escrito, quando já havíamos estabelecido as personagens da história. Por essa razão, pesquisadora e alunos decidiram atribuir nova função a ele: com o texto escrito em mãos, ajudaria nos ensaios (fazendo o papel do "ponto") e assumiria a execução da sonoplastia da peça no dia da apresentação.

As próximas aulas (17 a 20) foram dedicadas à realização do texto dramático oralizado/representado, a partir das indicações presentes no texto escrito. A marcação das cenas no palco condiz com uma espécie de "coreografia do movimento da cena" (SPOLIN, 2010), isto é, a maneira como os atores podem movimentar-se no espaço determinado como cenário da peça, o modo como podem oralizar o texto e, enquanto oralizam, como agem.

Para realização das atividades propostas nessas aulas, a disposição da sala modificouse: carteiras e cadeiras foram afastadas, de modo a compor um espaço central, servindo de palco aos ensaios. A primeira etapa que caracterizou a marcação das cenas consistiu da leitura das falas que compõem a cena a ser marcada. Em círculo, os alunos participantes leram o texto, já ressaltando as intenções das personagens, buscando imprimir volume e naturalidade ao diálogo. Os demais alunos que não estavam presentes na cena a ser marcada permaneceram em pequenos grupos, estudando seus papéis e, em outros momentos, ocuparam a posição da plateia, a fim de ajudar os colegas-atores na execução de suas performances.

Com base na leitura do texto, o cenário e os itens necessários à cena foram estabelecidos coletivamente. Pesquisadora e alunos decidiram utilizar os materiais disponíveis na sala de aula, para facilitar a visualização do cenário. Assim, a área do palco foi delimitada com carteiras (mesa para "os parabéns", mesa para os convidados) e com cadeiras (para o quarto das irmãs, para os convidados e para guardar os presentes recebidos na festa). A aluna que faria a personagem Socorro solicitou pedir à zeladora da escola uma vassoura, para que pudesse realizar sua ação de "limpar a casa para festa". Os demais acessórios cênicos (bolo de aniversário, garrafa de refrigerante, presentes etc.) foram manipulados a partir da técnica teatral conhecida por "objeto no espaço", aquilo que torna o invisível, visível aos olhos da plateia (SPOLIN, 2010). 
O próximo passo consistiu da livre dramatização da cena, em outras palavras, a passagem do texto obedeceu à espontaneidade dos alunos-atores e ocorreu à maneira como eles imaginavam que a cena pudesse ser conduzida no palco. Com o texto escrito em mãos, os alunos encenaram a seu modo, ocupando o espaço do palco e respeitando a limitação do cenário. Nesse momento, os alunos verbalizaram as falas e propuseram as situações de ação e movimento; durante essa passagem do texto, não houve interferência da pesquisadora, nem dos demais alunos.

Em nossa sequência didática em torno do gênero discursivo texto dramático, a pesquisadora assumiu o papel de diretora da peça, cujas funções foram planejar ensaios (quais cenas seriam priorizadas em cada aula) e auxiliar alunos-atores a se posicionarem no palco e a se apresentarem (como personagens) para plateia.

Antes de solicitar a terceira passagem do texto, a diretora mencionou os ajustes que mereciam ser feitos, com base na observação da passagem de cena realizada anteriormente. Essas orientações recobriram o desempenho oral (volume, dicção, controle da velocidade da fala), a construção da personagem (intenções das falas, expressão corporal) e a atuação multimodal (modos de falar e agir, não falar e agir, não agir e falar, movimentar-se, direcionar o olhar).

Desta vez, os alunos puderam optar por fazer a passagem da cena com apoio do texto escrito ou sem. Lembramos aos alunos que haveria auxílio do "ponto", em caso de não se lembrarem das falas. A passagem do texto foi interrompida algumas vezes, para que se fizessem os ajustes necessários à cena: estabelecimento das entradas e saídas das personagens conforme disposição do cenário (porta da rua, acesso aos quartos da casa), localização das personagens no espaço (onde se sentar, para qual lado servir os convidados etc.), observação das convenções teatrais: não virar de costas para plateia, manter a postura ao falar, se estiver parado, não mexer as pernas, evitar "dançar" para frente ou para os lados, procurar não realizar movimentos que não condizem à ação da personagem (ajeitar cabelo, segurar na roupa, por exemplo), buscar falar pausadamente, mas não de forma "robótica", cuidar da pronúncia das palavras (como o uso do " $r$ " final dos verbos, tendo em vista a neutralização do fonema $/ r$ retroflexo).

O processo que caracterizou a marcação das cenas repetiu-se ao longo das quatro (04) aulas designadas para esse fim: ao final de cada aula, avisávamos a respeito das cenas que 
seriam marcadas na aula seguinte e comunicávamos que as cenas já marcadas seriam novamente ensaiadas sem apoio do texto escrito. As imagens, a seguir, ilustram alguns momentos dos ensaios em sala de aula, em que podemos observar, na Imagem 20, alunas (à frente) realizando a primeira cena da peça e um grupo (aos fundos) estudando suas falas; e, nas Imagens 21 e 22, a passagem das cenas 02 e 03, respectivamente.
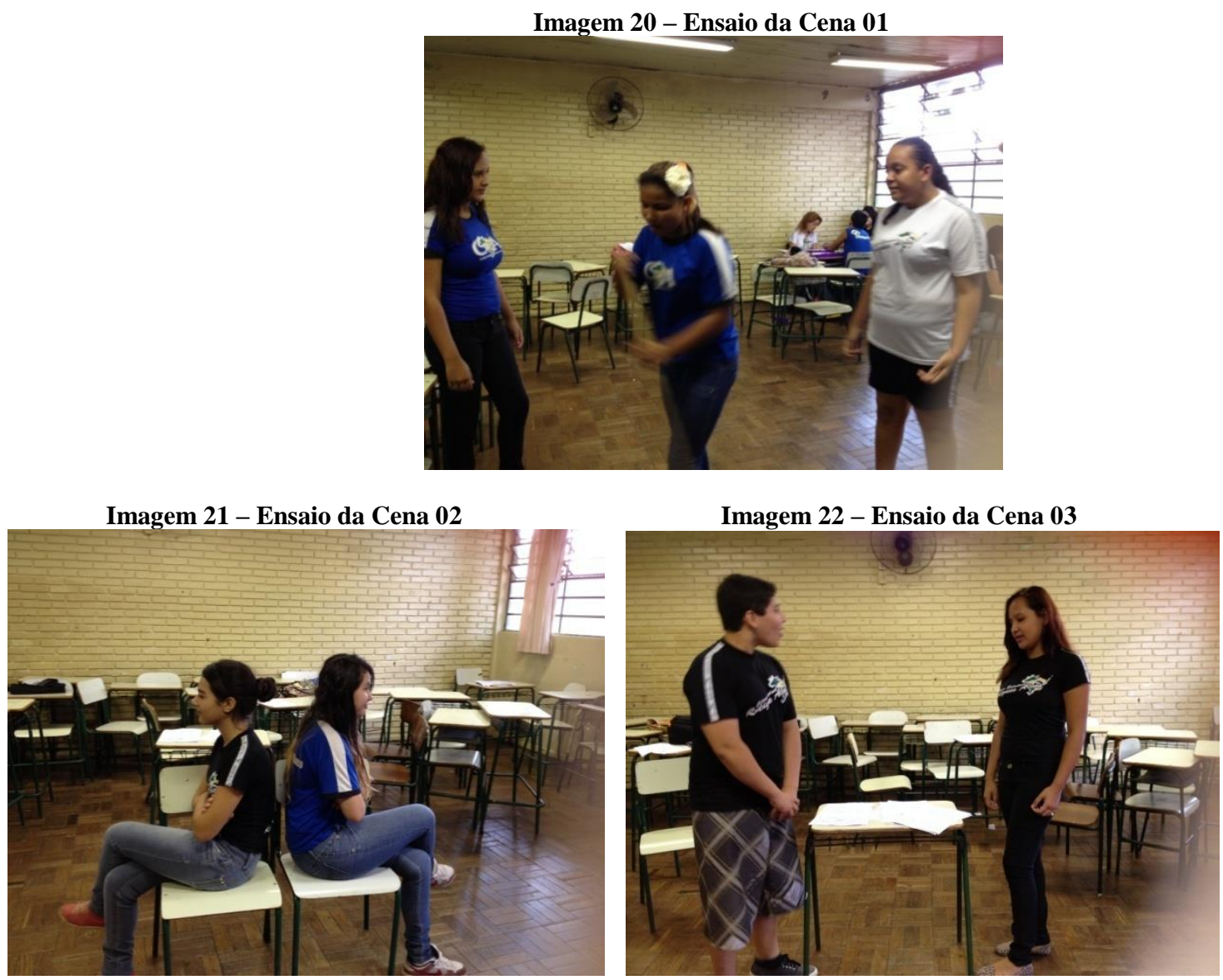

Em nossa sequência didática, os ensaios tiveram por objetivo a memorização das falas e a consolidação da movimentação e das intenções da personagem em cada cena. A esse respeito, Iturbe (2007) acrescenta que, de modo mais amplo

O ensaio é uma grande escola dos valores mais esquecidos hoje: repetição, paciência, trabalho, depender dos outros, apoio mútuo, monotonia, perseverança, trabalhar para um futuro mais ou menos longo, e não para o momento iminente, esforço em troca de algo posterior e para todos, não "útill" ou "material", não em troca de prêmios, dinheiro ou guloseimas, nem mesmo de notas (ITURBE, 2007, p.11). 
Entendemos que o momento dos ensaios de um texto dramático pode ser repetitivo e, por vezes, cansativo. Em nossa pesquisa-ação, houve controvérsias; por um lado, alguns alunos disseram “É pra passar a cena de novo? Mas a gente já passou duas vezes!” e, por outro lado, alguns solicitaram "Eu quero passar nossa cena mais uma vez!", "Professora, quando vai ser nossa vez de ensaiar?".

Nas aulas em que ocorreram os ensaios, os alunos puderam experimentar os papéis de atores e plateia. Ao assumiram a posição de plateia, comentaram a performance dos colegas em cena: "fala mais alto!", "você esqueceu da fala X!"; ao assumirem a posição de atores, procuraram manter o foco, em razão, principalmente, do receio de errar o texto. A nosso ver, a observação das ações dos colegas-atores, enquanto aluno-espectador, ajudou, também, na própria auto-observação, enquanto aluno-ator.

Destacamos, ainda, outro dado que aponta para o engajamento do grupo nos ensaios: quando algum aluno participante de determinada cena faltava, prontamente havia disputa para ver quem o substituiria no ensaio; alguns alunos já sabiam, inclusive, as falas dos colegas. Compreendemos, assim, que a experimentação de outras personagens consistiu importante oportunidade para ampliação das competências interativa, comunicativa e expressiva dos alunos.

Na Aula 21, efetuamos o ensaio geral da peça, observando - no cotejo do texto escrito - acréscimos ou supressões, improvisações, escolha de vocabulário, modos de falar, expressar-se e se movimentar. Verificamos, junto aos alunos, a maneira pela qual decidiram realizar a interpretação do texto escrito, por exemplo, na seleção de outras palavras para determinadas frases. Uma aluna optou por falar "meninas" ao invés de "amigas", pois, segundo ela, soava mais natural. Outro aluno improvisou uma fala ao acrescentar uma nova frase à já existente: “Querem suco, meninas? Eu mesmo preparei!”.

Os alunos observaram, também, que algumas alterações poderiam ter sido feitas no texto escrito (na revisão colaborativa do texto), tendo em vista sua produção oral: rearranjar o alongamento da vogal “o", na fala "Sooooocorro!", que deveria estar na segunda sílaba; acrescentar falas nos momentos de servir/receber os convidados, já que, para eles, "ficou meio que um vazio nessa hora". Um aluno verificou, ainda, que as meninas foram servidas duas vezes (de refrigerante e salgadinhos), e os meninos nenhuma vez; sua sugestão foi alterar esse 
segmento: "JOAQUIM - Querem salgados, meninas? TODAS - Não, obrigada" por “JOAQUIM - Querem salgados, meninos? TODOS - Sim!”.

Ocorreram situações em que os alunos se perguntaram se deveriam estar em cena, mesmo não tendo registro de fala no texto escrito. A dúvida tem por base o fato de que, no texto escrito, os convidados permanecem em cena, no momento da passagem de uma cena a outra, mas esse dado não foi reforçado nas indicações (rubricas). Outro dado bastante significativo foi a constatação de que os alunos-dramaturgos não haviam escrito falas para a personagem Verônica. A personagem era apenas citada, comentada por outras ou evidenciada nas rubricas "As duas entram na sala. Quando Fernanda vê as duas, começa uma discussão", "Verônica dá risada". Orientamos, para tanto, que a adaptação ao texto e o acréscimo das falas da personagem Verônica fossem realizados pela aluna-atriz que interpretaria essa personagem, durante o ensaio geral.

Houve, também, dúvidas no momento de interpretar algumas rubricas estabelecidas pelos alunos-dramaturgos, por exemplo, como dizer ao convidado que não trouxe presente para as aniversariantes a seguinte fala: “(com desprezo) Tudo bem”? Ou qual posicionamento deveriam ocupar, a partir da indicação "Todos se reúnem em volta da mesa e começam a cantar parabéns"? Além disso, na produção oral/multimodal do texto dramático, os alunos precisaram estipular como fariam para entrar em cena (de qual lado do palco) e para onde iriam (sentar-se, ficar de pé ao lado da mesa, parar diante da plateia), já que, no texto escrito, não havia os pormenores dessas movimentações. Entendemos, assim, que a produção oral do texto dramático ancora-se nas indicações do texto escrito, mas recorre, também, à interpretação e escolhas ajustadas entre atores e direção.

As próximas aulas foram dedicadas às atividades que compuseram o Módulo 5 Circulação, que passamos a descrever na seção a seguir.

\subsubsection{Módulo 5 - Circulação}

Na Aula 22 (2h/a), os alunos produziram os materiais de divulgação da peça (cartazes e programa) e fizeram o levantamento dos itens do cenário, figurinos e sonoplastia. Essa foi a 
última aula do projeto pedagógico realizada no ambiente escolar; a próxima já configuraria a apresentação no teatro.

Os alunos produziram, primeiramente, os cartazes de divulgação da peça. Houve levantamento de informações características do gênero "cartaz de uma peça teatral": nome da peça, dia da apresentação, horário e local, inserção de expressões como "vem aí", "em breve", “estreia”, “o $8^{\circ}$ ano E apresenta...”. Algumas particularidades da apresentação teatral (escolar) também foram assinaladas: isenção dos valores do transporte e dos ingressos e indicação do público-alvo (alunos dos $8^{\text {os }}$ e $9^{\text {os }}$ anos do Colégio Estadual Rodrigues Alves, do período da tarde). As orientações foram registradas no quadro de giz e, na sequência, os alunos reuniramse em grupos para produção dos cartazes. Cada grupo recebeu os materiais para realização da atividade; cartolinas brancas, tesoura, cola, papéis coloridos e canetinha (Imagens 23 e 24). Destacamos na Imagem 25, a seguir, o resultado da produção de um dos cartazes.
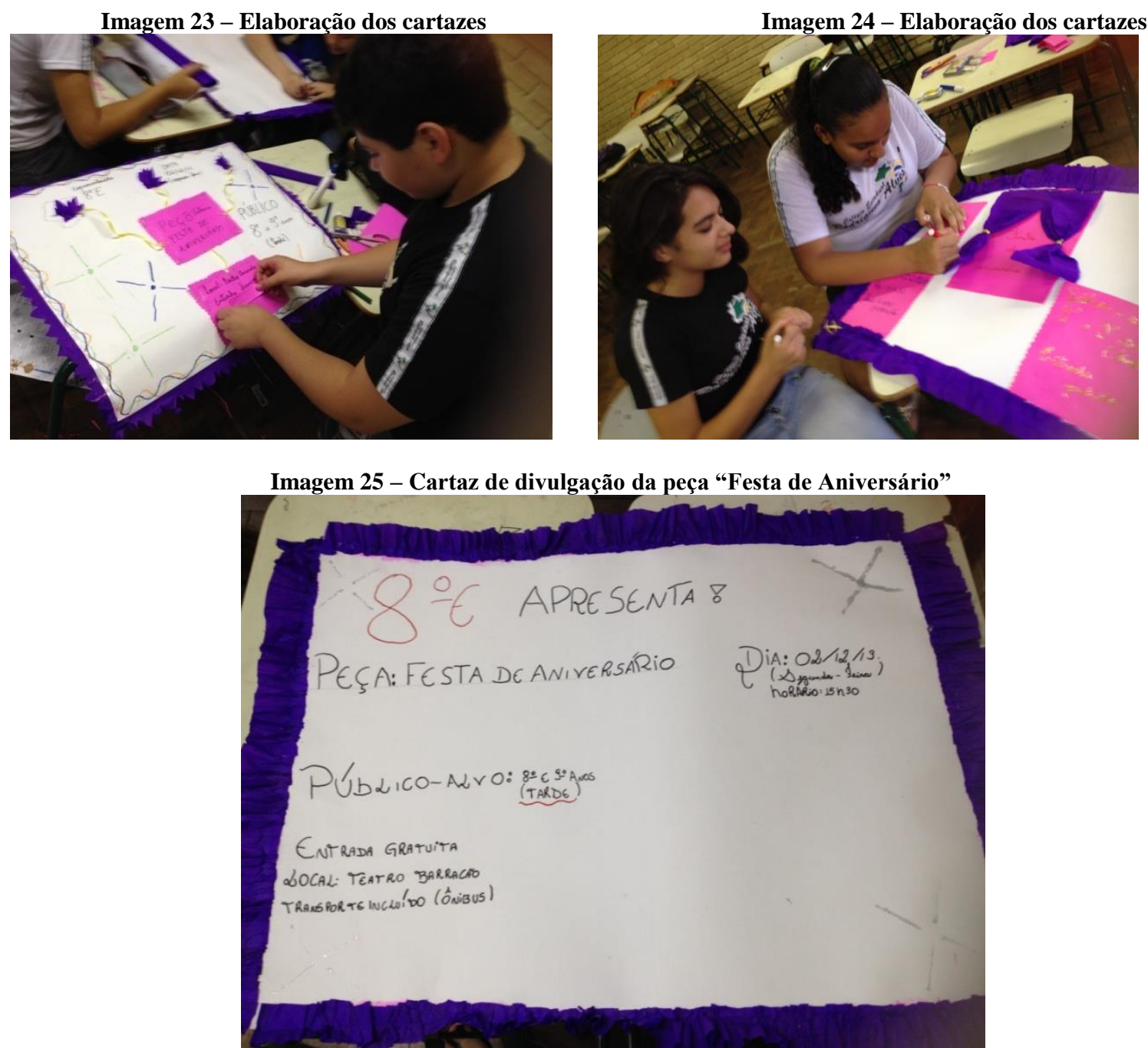
Na sequência, os alunos produziram o programa da peça, que seria distribuído à plateia, no teatro, antes do início do espetáculo. Relembramos os itens constantes do programa da peça "O Vilarejo" e fizemos o registro, no quadro de giz, das informações necessárias ao gênero "programa de uma peça teatral": nome da peça, elenco (atores/atrizes e suas respectivas personagens) e ficha técnica (direção, luz, som, cenário, texto).

Levando em conta a disposição desses itens na folha de papel, os alunos decidiram dar ênfase ao nome da peça e à apresentação do elenco. Isso é decorrente do acordo entre alunos e pesquisadora quanto às informações que mereciam constar do programa da peça e que haviam sido listadas no quadro de giz. Apresentamos, a seguir (Imagem 26), o programa da peça, produzido pelos alunos:

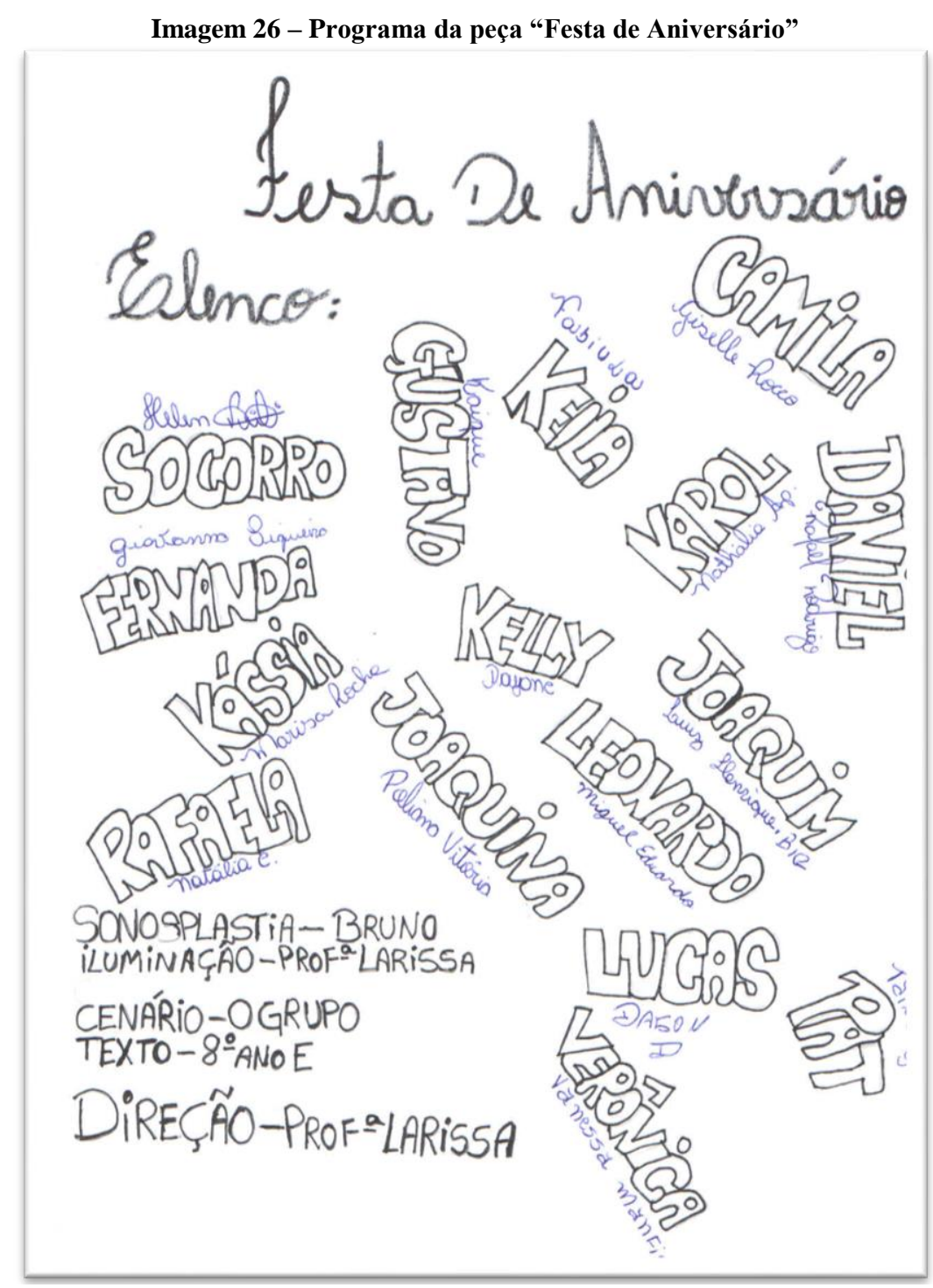


Dois alunos ficaram responsáveis pela produção do programa da peça; abaixo ou acima do nome de cada personagem, os alunos-atores assinaram seus nomes. Enquanto isso, os demais se reuniram para definir os itens necessários para apresentação: cenário e figurinos. De posse do texto escrito, revisaram os acessórios cênicos de cada personagem e fizeram uma lista dos itens que cada aluno poderia providenciar:

- Fone de ouvido - Nathália

- Velas de 15 anos - Poliana

- Fósforo - Poliana

- Bolo falso - Rafael

- Espátula para cortar o bolo - Rafael

- Pratinhos plásticos para o bolo - Rafael

- Garfinhos plásticos - Rafael

- Guardanapos - Giovanna

- Copos plásticos - Hellen

- Refrigerantes - Hellen e Fabíula

- Um par de brincos para Keila - Vanessa

- Um par de brincos para Kelly - Vanessa

- Painel: "Feliz aniversário" - Fabíula

- Presentes da Rafaela (02) - Natália

- Presentes da Fernanda (02) - Giovanna

- Presentes do Daniel (02) - Rafael

- Presentes do Leonardo (02) - Miguel

- Presentes do Lucas (02) - Dagon

A pesquisadora responsabilizou-se pelos demais itens levantados: vassoura, mesa para os parabéns, mesas e cadeiras para os convidados (disponíveis no teatro), toalhas para as mesas, puffs para o quarto das gêmeas, tecidos coloridos, bexigas e salgadinhos/guloseimas para a festa. 
Quanto aos figurinos, os alunos disseram que, por se tratar de uma festa de aniversário, poderiam usar roupas "de sair pro shopping" ou "ir pra balada". Exceções deveriam ser feitas para os papéis "mãe", "pai" e "avó", que deveriam usar roupas compatíveis com esses estereótipos, bem como as aniversariantes, que deveriam se sobressair aos convidados e, segundo os alunos, "chamar a atenção de todos".

Durante a realização das atividades citadas anteriormente, o aluno responsável pela sonoplastia da peça efetuou a escolha do repertório musical e apresentou aos alunos. Houve discussão em torno das músicas selecionadas, os alunos tiveram de chegar a um consenso, algumas músicas foram mantidas e outras substituídas, devido ao gosto da maioria. Assim, foram estabelecidas oito (08) músicas para a peça "Festa de Aniversário", dentre essas, o som da campainha da casa (que já estava prevista nas rubricas do texto escrito). Sugerimos ao aluno-sonoplasta que registrasse em seu próprio texto as "deixas", isto é, as falas/ações das personagens que marcariam a entrada/saída das músicas, para orientar a execução da sonoplastia durante a apresentação teatral, conforme destacamos:

- $\quad$ Música 01 - Wake me up (Avicii)

Entrada: após fala de Kelly "Isso é o que veremos" (cai a luz).

Saída: Joaquim entra em cena.

- Música 02 - Pantera cor-de-rosa (Munhoz e Mariano)

Entrada: após fala de Camila "Eu não sei pra quem que é” (cai a luz).

Saída: após cinco segundos.

- Música 03 - som de campainha

Entrada: a família arruma a mesa dos parabéns.

Saída: Karol vai até a porta.

- Música 04 - som de campainha

Entrada: após fala de Fernanda “Joaquina, eu vou querer um salgadinho".

Saída: Joaquina vai até a porta.

- Música 05 - som de campainha

Entrada: após a fala de Gustavo "Tomara que ele nem venha, assim sobra mais salgadinho".

Saída: Karol vai até a porta.

- Música 06 - som de campainha 
Entrada: após a fala de Joaquim "Querem salgados, meninos?"

Saída: Lucas vai até a porta.

- $\quad$ Música 07 - Turn up the music (Chris Brown)

Entrada: após a fala de Lucas “Gente, vamos parar com isso, é festa, vamos nos divertir!"

Saída: a mãe se aproxima do bolo para começar a cantar os parabéns.

- Música 08 - Papo reto (Charlie Brown Jr.)

Entrada: após a fala de Socorro "Aff! Maçã com coco, que nojo! Eca!”

Saída: após o agradecimento à plateia.

Ao final dessa aula, os alunos receberam um formulário de autorização que deveria ser assinado pelos pais ou responsáveis e entregue à coordenação ${ }^{61}$. O documento explicitava o horário de permanência dos alunos no teatro, para ensaio e apresentação da peça "Festa de Aniversário". Como encerramento das atividades do dia, os alunos afixaram os cartazes de divulgação da peça nos corredores das salas de aula e no pátio da escola. A ação coincidiu com o início do intervalo dos alunos do turno da tarde; em meio à curiosidade de alguns alunos da escola, nossos alunos-produtores puderam explicar o conteúdo dos cartazes e reforçar o convite.

O último encontro com os alunos do $8^{\circ}$ ano E realizou-se no teatro (Aula 23). A expectativa para finalização do projeto pedagógico se fazia imensa, após vinte e dois (22) encontros, pesquisadora e alunos estavam ansiosos pela apresentação que estava por vir. Combinamos de nos encontrar no portão central da escola para, juntos, seguirmos de ônibus até o local. A maioria dos alunos chegou à escola no horário estipulado, outros, porém, não vieram.

Sabemos que imprevistos como esses podem acontecer. Grupo e pesquisadora sentiram os desfalques. Ao todo, quatro (04) alunas faltaram à apresentação e uma (01) chegou pouco tempo antes do início do espetáculo. Dentre as alunas que faltaram, apenas uma

${ }^{61}$ Cf. Anexo XVI. 
(01) justificou-se por telefone: devido à temática da peça e por motivos pessoais, a mãe não autorizou a filha a se apresentar ${ }^{62}$.

Diante da situação instaurada, observamos a necessidade de reorganização das atividades. Uma aluna prontificou-se a substituir uma personagem, já que ela aparecia somente na primeira e na última cena da peça. Ainda assim, seria preciso solucionar a ausência de três (03) personagens, dentre elas, uma das protagonistas da peça (gêmea aniversariante), a mãe e uma convidada. Como não havia tempo para adaptar todo o texto entre os alunos presentes, a pesquisadora informou aos alunos que entraria em contato com três (03) estudantes que participaram da peça "O Vilarejo" para convidá-las a assumirem essas personagens.

A possibilidade do "intercâmbio teatral" entre escolas foi comemorado pelo grupo; aliviados, os alunos disseram ter ficado com medo de não se apresentarem e receio de que todo o trabalho pudesse ter sido em vão. Ajustada a situação, retomamos a expectativa e, certamente, redobramos a ansiedade. Ao chegarmos ao teatro (três horas antes do espetáculo), os alunos puderam guardar seus pertences nos camarins e organizar seus figurinos. Primeiramente, realizamos uma atividade para retomar a união e restabelecer a confiança do grupo - trata-se de um jogo teatral. Descrevemos, a seguir, o jogo escolhido para esse momento, "História em Grupo":

\section{Aplicação do jogo: História em grupo}

Solicitamos aos alunos que se sentassem em círculo, no palco do teatro. Iniciamos a explicação do jogo, dizendo que a proposta era contar uma história de modo coletivo. Cada um deveria contribuir com a história acrescentando apenas uma palavra. $\mathrm{O}$ aluno sentado à direita de quem acabou de se pronunciar deveria completar a palavra anterior com outra palavra e, assim, sucessivamente, até todos participarem da história.

Algumas situações marcaram esse jogo: quando um aluno não conseguia encontrar uma palavra que combinasse com o que estava sendo dito anteriormente, os demais prontamente o ajudavam; o nível de coerência da história aumentava, na medida em que também aumentava a generosidade e confiança dos alunos; a concentração dispensada para este jogo unificou, enfim, as ações/pensamentos do grupo como um todo.

\footnotetext{
${ }^{62}$ Esse dado aponta para o fato de que, em uma próxima oportunidade, é considerável o envio da autorização para apresentação no teatro com pelo menos quinze dias de antecedência, seguido de um convite aos pais para assistirem à peça produzida.
} 
Ainda dispostos em círculo, solicitamos aos alunos a passagem do texto completo, com apoio do texto escrito, para que as alunas que assumiram o papel das ausentes pudessem inteirar-se das situações propostas e das falas de cada cena. Diante das novas interações estabelecidas, entendemos a necessidade de enfatizar os ensaios dessas cenas. Por essa razão, a leitura foi realizada mais de uma vez.

Na sequência, iniciamos a montagem do cenário, conforme destacamos nas Imagens 27 e 28 , a seguir:
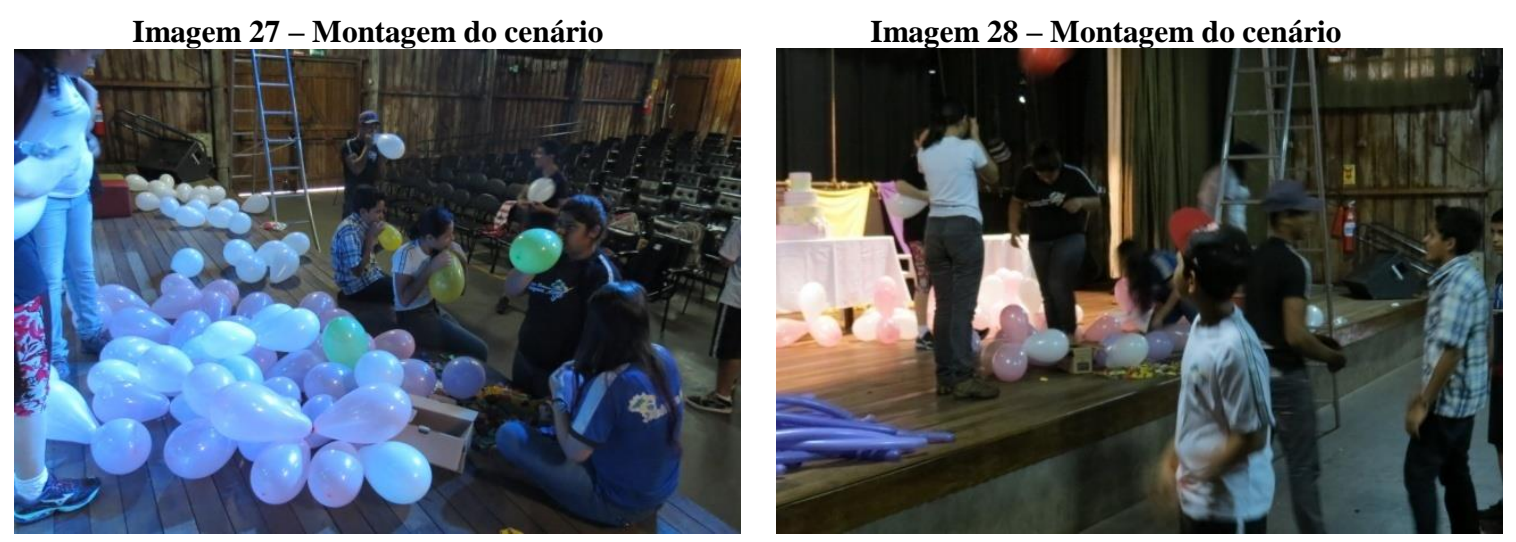

Realizamos, em seguida, um ensaio geral, a partir das marcações de palco previamente estabelecidas em sala de aula. Procedemos à explicação de novas marcações, tendo em vista a adaptação ao espaço do teatro, o posicionamento dos itens do cenário, e a entrada e saída das personagens (Imagem 29). Esse ensaio ocorreu, também, com a execução da sonoplastia (Imagem 30).
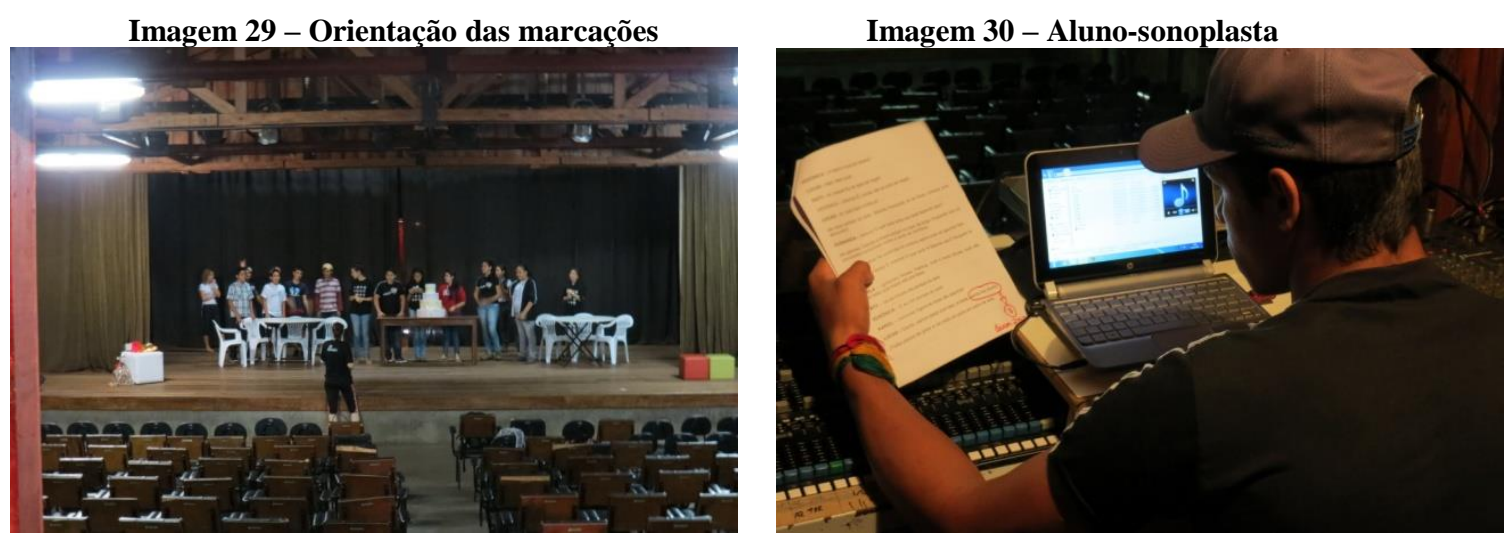
Após um intervalo para almoço, retomamos as atividades no teatro: finalizamos o cenário e realizamos ensaio geral com figurino e iluminação. Na sequência, efetuamos aquecimento vocal e corporal (Imagens 31 e 32):
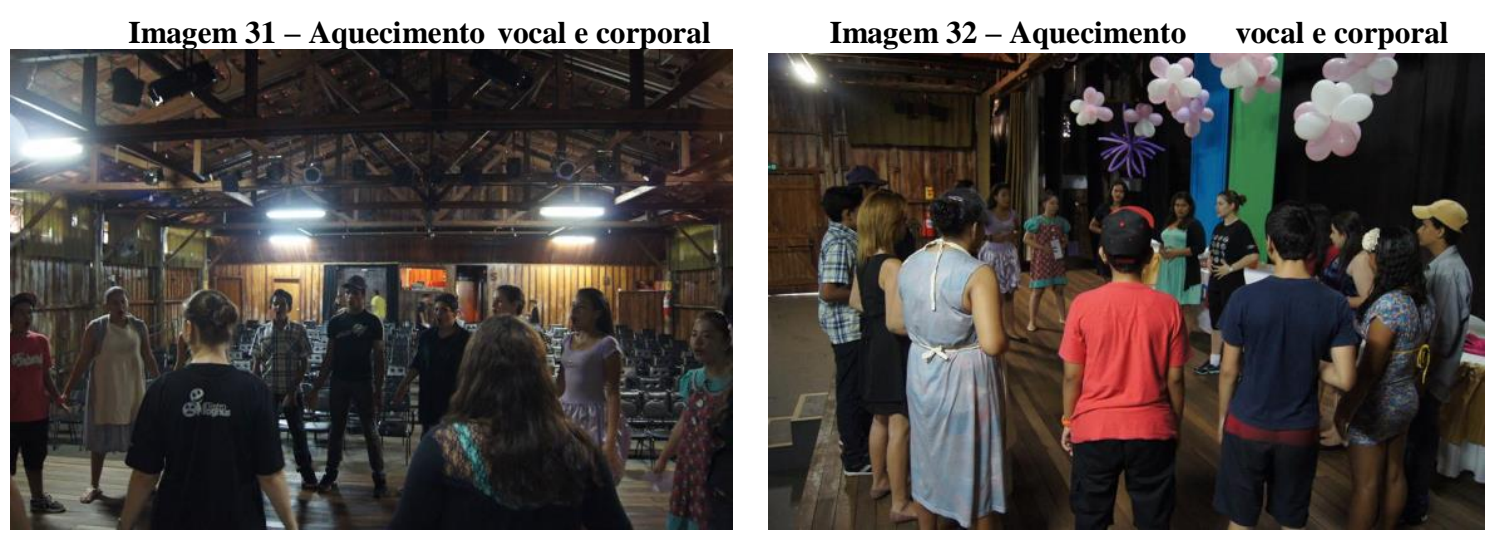

Salientamos a importância do aquecimento vocal e corporal para apresentação de um espetáculo teatral, devido ao fato de configurarem, na prática discursiva de referência, voz e corpo como instrumentos de ofício do ator profissional. Assim, com intuito de aproximar os alunos participantes da pesquisa-ação ao conjunto de práticas inerentes ao "ritual" da representação cênica, conduzimos, junto aos alunos do $8^{\circ}$ ano $\mathrm{E}$, uma sequência de exercícios de alongamento corporal, respiração, vocalização e articulação, com base em nossa experiência em oficinas de teatro.

Chegada à hora do início do espetáculo, os alunos-atores assumiram suas posições nas coxias. A plateia chegou ao teatro, acompanhados por professores de sala e pela coordenação, em ônibus disponibilizado pela Prefeitura de Maringá. Ao entrarem no teatro, os alunosespectadores foram recepcionados com o programa da peça "Festa de Aniversário". Na sequência, a pesquisadora-diretora procedeu à apresentação do espetáculo, explicando-o no bojo do desenvolvimento do projeto pedagógico em torno do estudo do texto dramático (Imagem 33). 


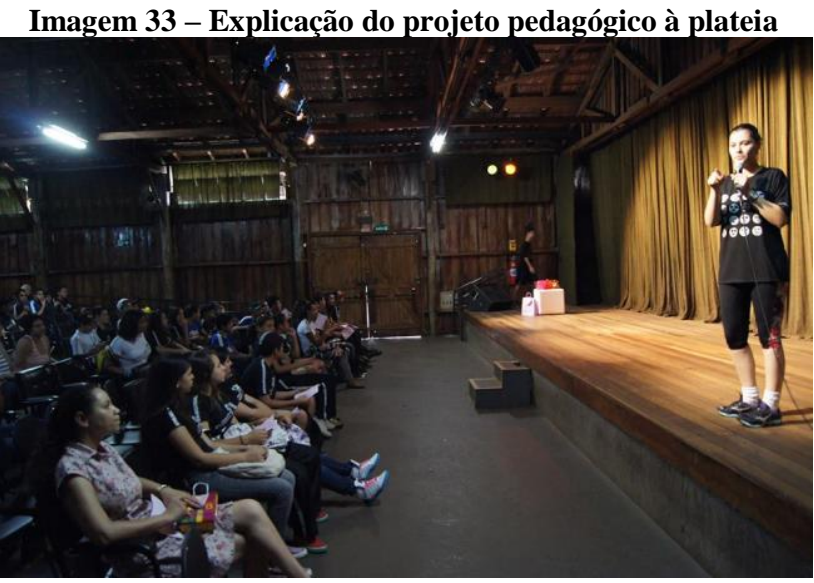

As imagens, a seguir (34 a 38), resumem a apresentação teatral da peça "Festa de Aniversário". É oportuno esclarecer que disponibilizamos também, nos Anexos deste trabalho (CD-ROM), a gravação em vídeo da íntegra do espetáculo ${ }^{63}$ (Cf. Anexo XVII).
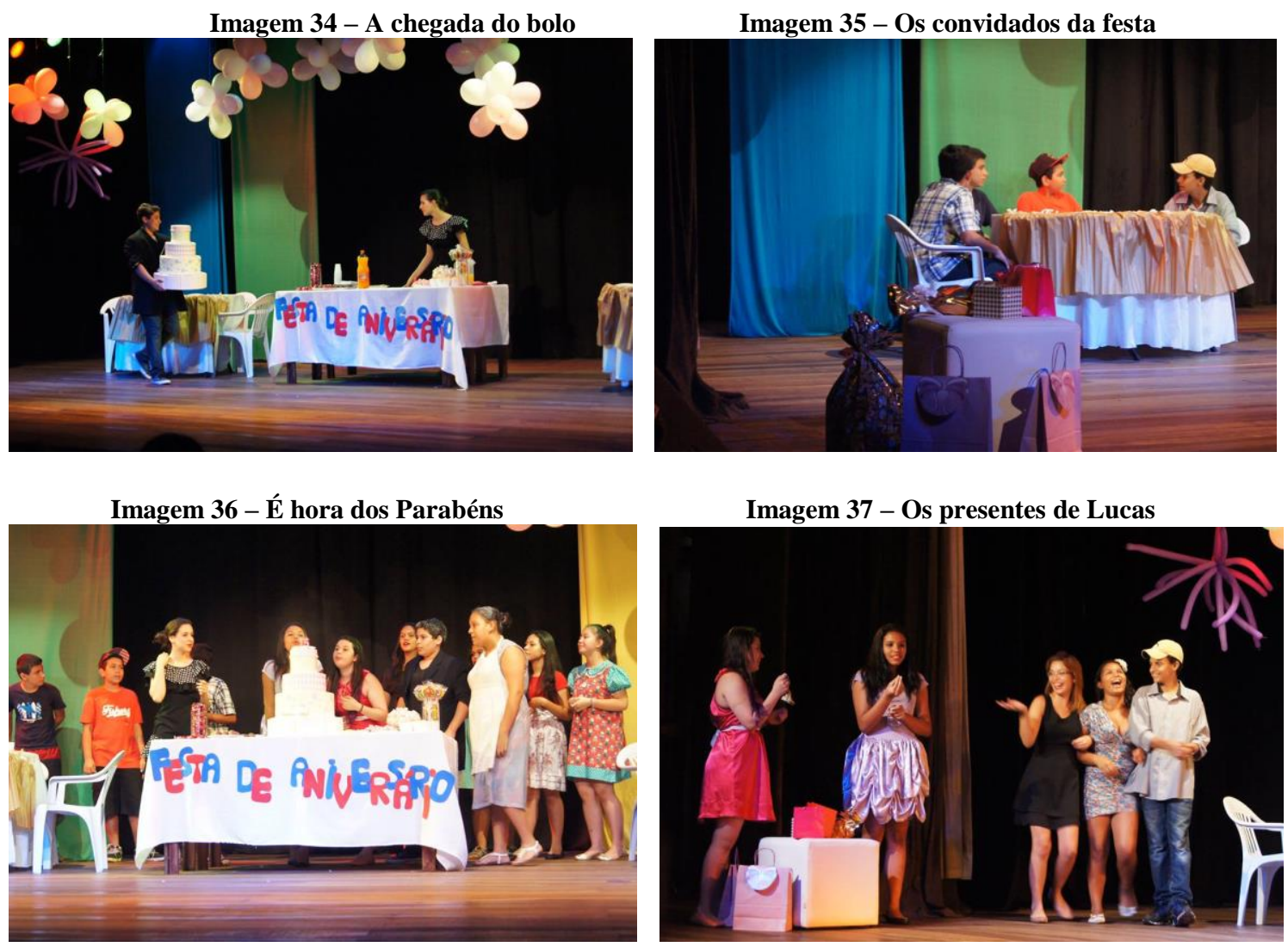

${ }^{63}$ Duração $11 \min 37 \mathrm{~s}$. 


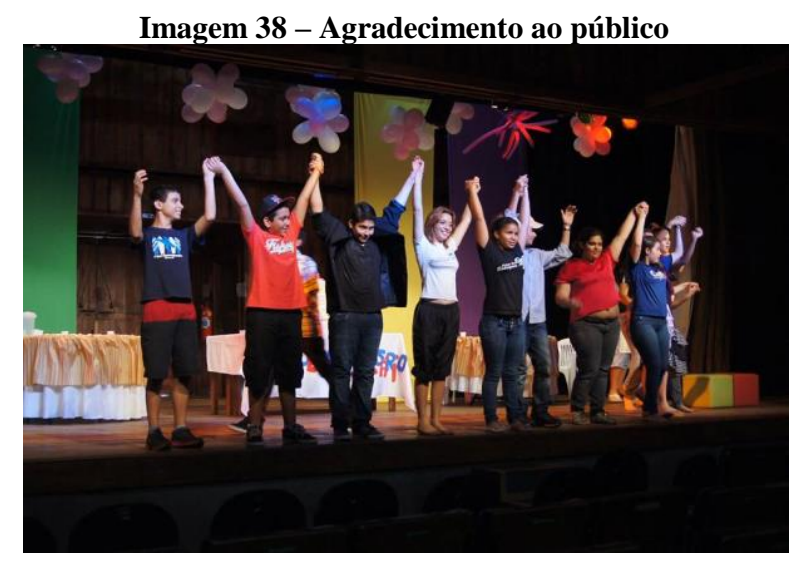

Conforme salienta Chacra (2010, p.84), "somente juntos - ator e espectador - podem constituir aquilo que se chama teatro". Durante a apresentação, houve participação efetiva da plateia: comentários, risadas e assovios. Certamente por reconhecerem os colegas-atores no palco, os alunos-espectadores sentiram-se à vontade para participar. Quando a cortina se abriu, por exemplo, houve reação imediata ao ver o cenário. Em muitos momentos, os alunosespectadores riram do texto dito pelas personagens: "Amor, cheguei!" (pai), "Será que o Lucas vem?" (irmãs gêmeas), "Tomara que o Lucas nem venha, assim sobra mais salgadinho" (Gustavo), "Se ela vier eu vou dar na cara dela" (Fernanda), "Eca! Maçã com coco!" (Socorro).

Esse dado é significativo, já que nos ensaios os alunos não tiveram resposta dos momentos de "piada" do texto; elas só se constituíram na interação com o público, no momento da representação cênica. Nos termos de Bakhtin (2003[1979], p.280), trata-se de uma particularidade de todo enunciado, a conclusibilidade ou "inteireza acabada do enunciado, que assegura a possibilidade de resposta (ou de compreensão responsiva)”.

Durante a apresentação, houve falhas na execução da sonoplastia, os alunos-atores precisaram improvisar ações/falas, pois, em um dado momento da peça, o aluno-sonoplasta demorou para soltar o som da campainha. Ainda assim, os alunos-atores sentiram-se seguros para continuar a cena, preenchendo com ações espontâneas a situação vivenciada pelas personagens. Segundo Ryngaert (2009, p.91), a improvisação teatral relaciona-se ao processo criativo do ator e se faz importante porque "representa uma experiência para o sujeito".

Outras improvisações aconteceram ao longo da peça; a mais emblemática foi no momento de cantar os parabéns para as aniversariantes. O elenco iniciou a música 
comemorativa antes mesmo de acender a vela do bolo, pois eles não haviam ensaiado "esperar acender a vela para cantar". Houve, assim, adaptação in loco, improviso, novamente.

Ao final da apresentação, os alunos-atores foram muito aplaudidos pelos alunosespectadores. Agradecemos a presença de todos e informamos que receberiam na saída do teatro uma cópia de tamanho reduzido do texto completo, para que pudessem ler o texto dramático que os colegas-dramaturgos escreveram e que acabaram de encenar.

Os alunos-atores se abraçaram nas coxias e festejaram nos camarins o sucesso do espetáculo. Parabenizamos muitíssimo o grupo pelo empenho e agradecemos a participação de todos os alunos no desenvolvimento da pesquisa-ação. Como último registro de atividade, solicitamos aos alunos-atores que respondessem: "Descreva, nas linhas abaixo, a sensação/emoção de apresentar a peça que escreveu em um teatro".

Como resposta, os alunos reforçaram o fato de terem realizado algo novo e que nunca haviam pensado/imaginado apresentar uma peça, conforme destacamos nos Excertos 9, 10 e 11:

Excerto 9

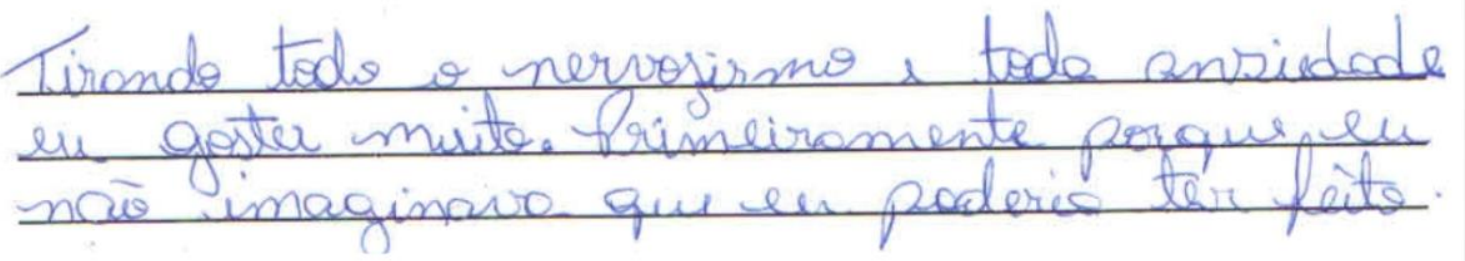

Excerto 10

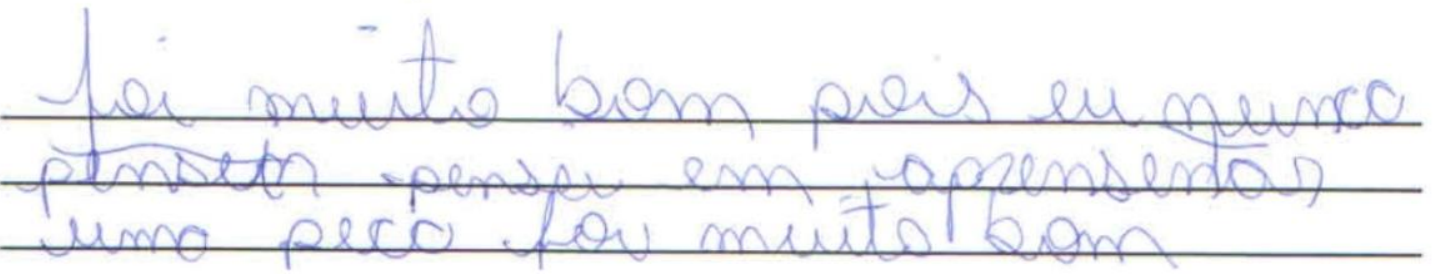




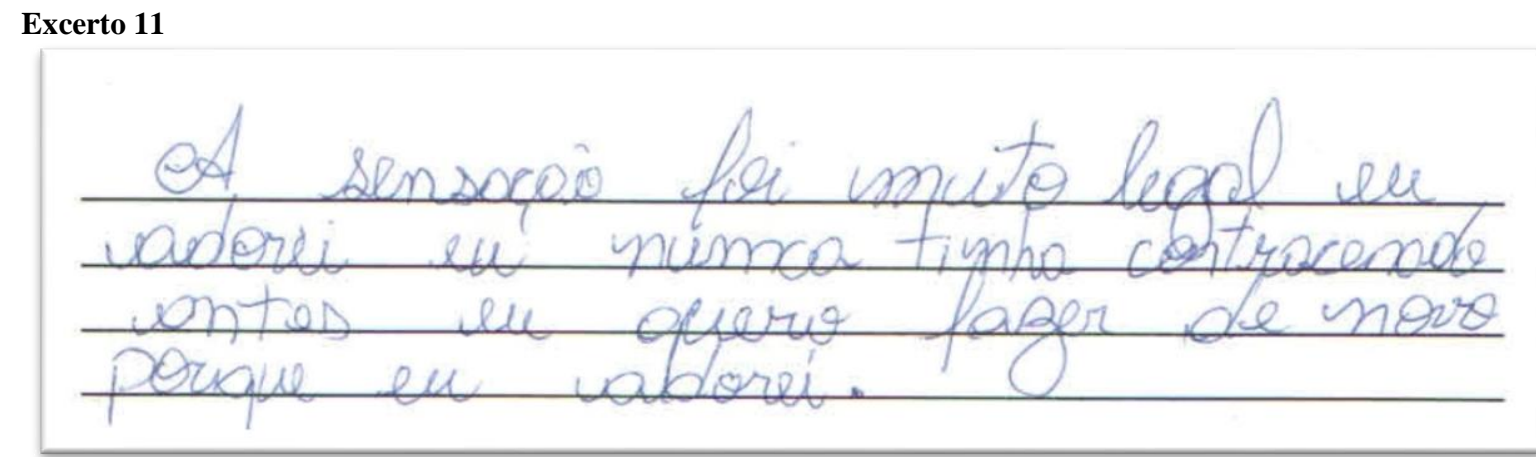

Outros alunos ressaltaram a experiência como positiva e sinalizaram querer repeti-la (Excertos 12 e 13):

\section{Excerto 12}

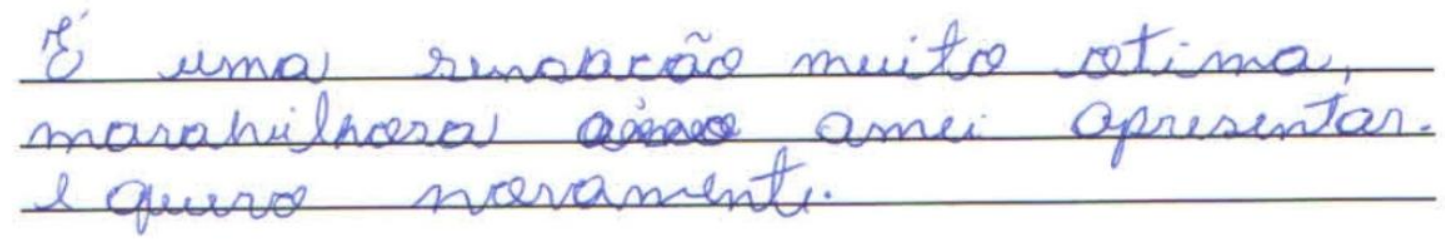

\section{Excerto 13}

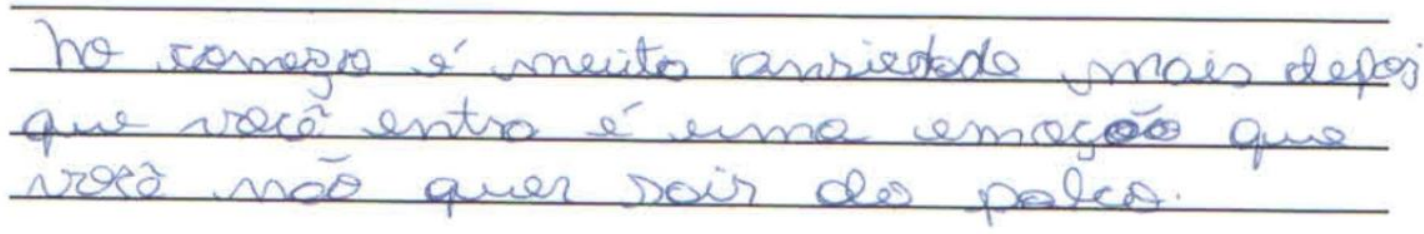

Alguns alunos indicaram as sensações que antecederam o espetáculo (angústia, nervosismo, ansiedade, "tremendo muito") e as que acompanharam a apresentação (tranquilidade, "faz valer a pena"), conforme podemos observar, a seguir (Excertos 14 e 15): 


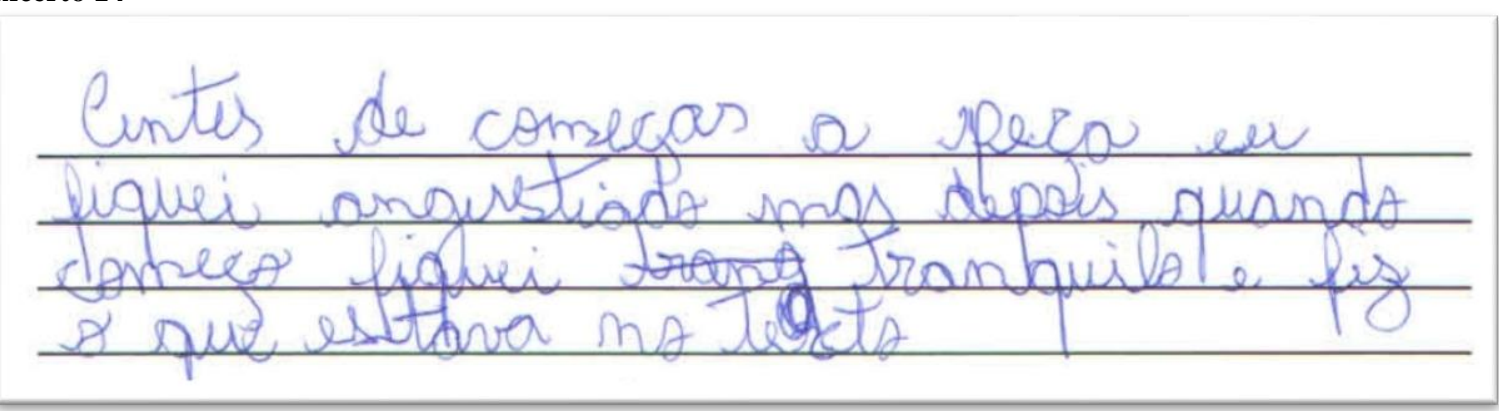

\section{Excerto 15}

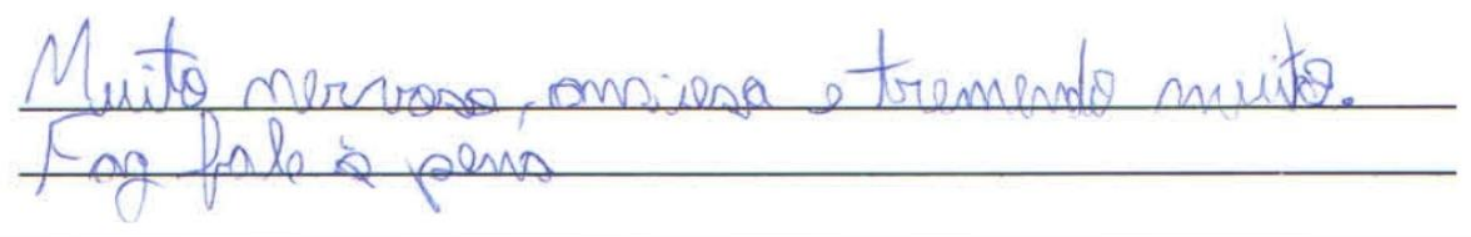

Um aluno escreveu a respeito da diferença entre se apresentar e assistir a uma peça teatral e destacou a responsabilidade de atuar (Excerto 16):

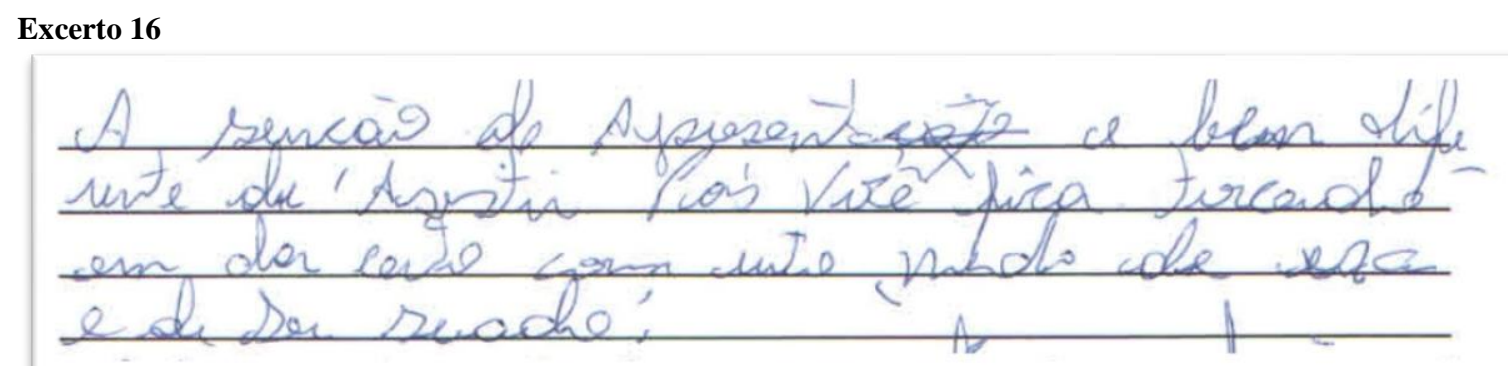

Finalizamos a aula com uma grande confraternização. Os alunos estavam alegres, comentaram a performance dos colegas, a reação do público, disseram que o tempo passou "super-rápido", lembraram das colegas que faltaram à apresentação e que não puderem vivenciar a experiência, agradeceram a oportunidade e verbalizaram o desejo de repeti-la.

Com relação à produção oral e multimodal dos alunos cabem, ainda, algumas observações. Entendemos que, ao oralizar o texto dramático e dar voz às falas da personagem, interpretando-as, a produção oral do aluno-ator é, ao mesmo tempo, envolvida e sustentada por recursos multimodais (entonação, ritmo e volume, expressão facial, gestualidade, 
direcionamento do olhar, ação e movimento, por exemplo) que ajudam a construir sua performance.

Apresentamos, a seguir, alguns desses recursos multimodais empregados pelos alunosatores na apresentação teatral "Festa de Aniversário" e que foram também utilizados em outras atividades já mencionadas (leitura dramática, ensaios). Salientamos que tais recursos ocorrem de modo simultâneo (fala com gesto, fala com movimento etc.), no entanto, serão descritos separadamente para facilitar a análise do material. A discussão que se segue não pretende ser exaustiva, buscamos destacar alguns exemplos que nos parecem representativos dos usos multimodais a que os alunos-atores recorreram para encenação da peça. Para apresentação desses dados, procedemos à descrição da cena e destacamos a imagem e a referência ao tempo em que se localiza no vídeo. Reiteramos, nesse sentido, que a gravação da peça produzida pelos alunos encontra-se nos Anexos deste trabalho (Cf. XVII).

Para exemplificar o uso de recursos prosódicos, selecionamos o momento em que a aluna-atriz que interpreta a personagem Camila (amiga das gêmeas) entra em cena e cumprimenta as aniversariantes (Imagem 39). Em sua fala "Oi, meninas!", o volume empregado é alto, e o enunciado é oralizado com bastante empolgação; na sequência, ela pergunta "Já decidiram qual vestido vão usar?", nesse caso, o volume se mantém, mas a entonação é outra, o tom agora é de curiosidade. Na próxima fala, há alongamento da vogal “o”, em "Nooooossa! Fiquei sabendo que o Lucas comprou dois presentes" e uma entonação ascendente que acompanha a sensação de novidade, surpresa.

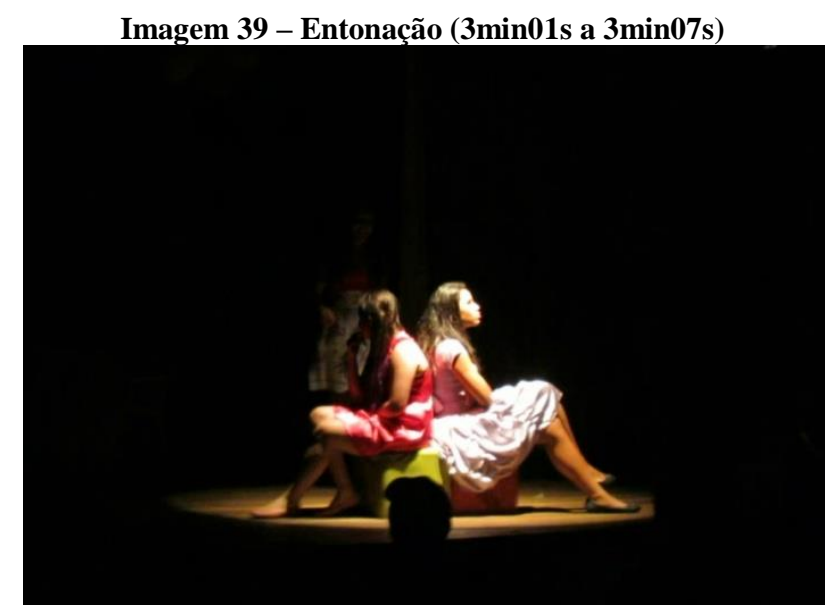


Quanto à gestualidade, selecionamos um momento em que as alunas-atrizes que interpretam as irmãs gêmeas, Keila e Kelly, indicam com a expressão corporal (braços cruzados, mão na cintura) a intenção dessas personagens. Na Imagem 40, a seguir, Keila, à esquerda, diz “Ah! Não sei, tomara que ele venha, vou colocar meu melhor vestido pra ele ficar reparando só em mim!”, enquanto Kelly, à direita, retruca a irmã “Ah! Pois ele vai ficar só comigo, ele não gosta de você!". Essas falas acompanham a expressão corporal das alunasatrizes, conforme observamos:

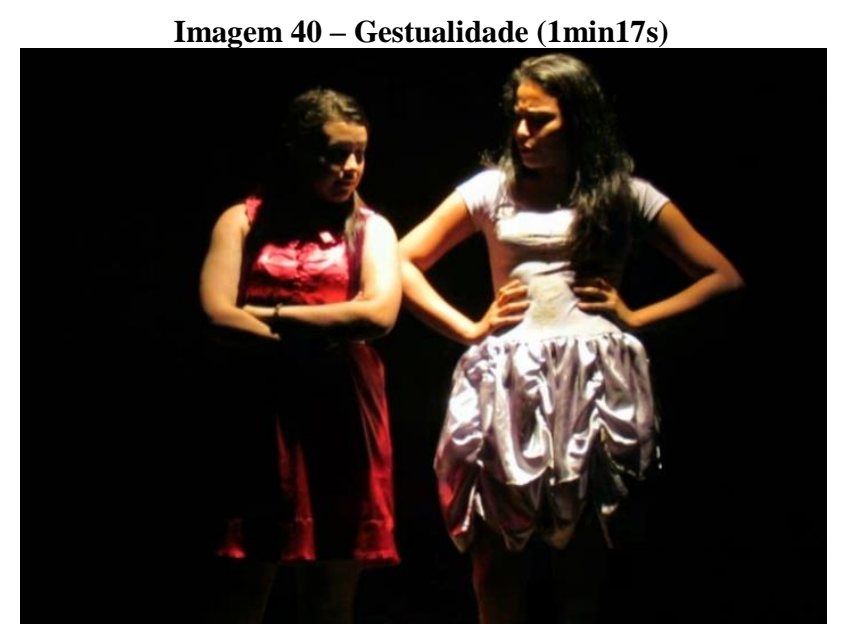

Em relação à expressividade facial, destacamos o momento em que as irmãs criam expectativas em torno dos presentes de Lucas. Observamos na Imagem 41, a seguir, as alunasatrizes revelarem com os olhos e com a boca o entusiasmo das personagens Keila, à esquerda, e Kelly, à direita:

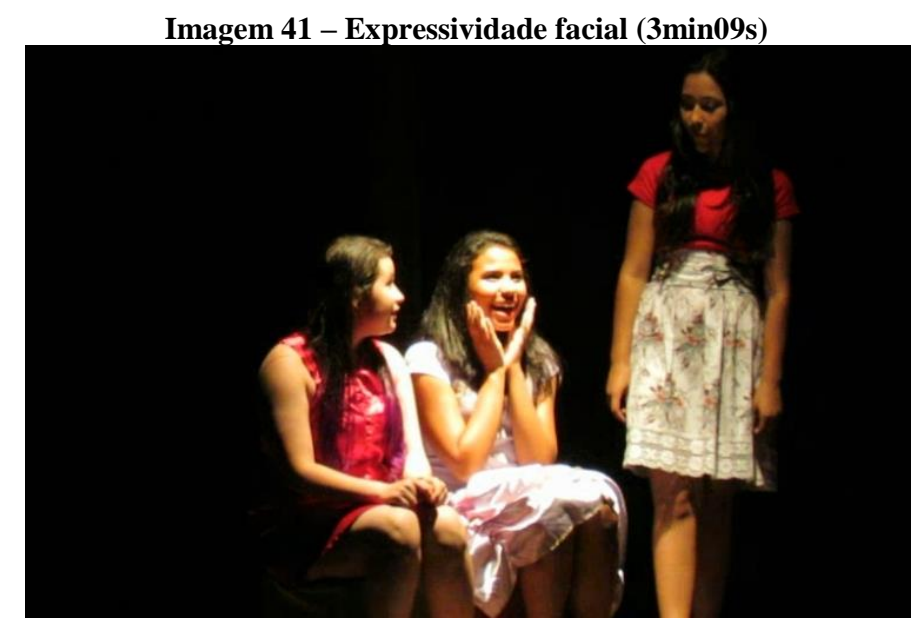


O direcionamento do olhar está presente no exemplo a seguir. Depois de cantar os parabéns, o aluno-ator que interpreta a personagem Gustavo diz "Finalmente, não vejo a hora de comer". Neste instante, todas as personagens da festa olham para ele, repreendendo-o, conforme podemos observar na Imagem 42 (em destaque):

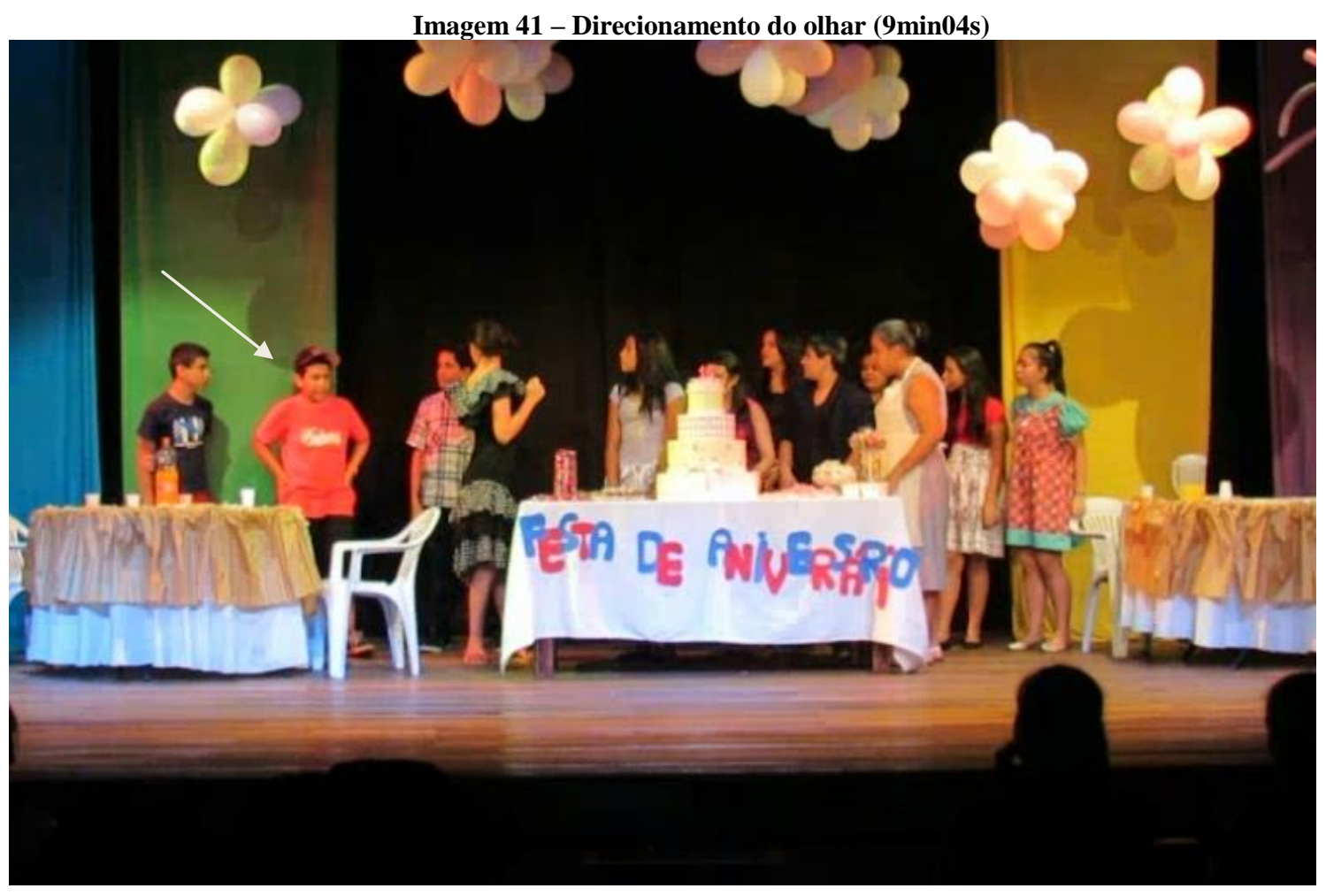

A ação dos alunos-atores realizou-se de diversas maneiras: na inter(ação) com os objetos cênicos, com o cenário, entre personagens e na movimentação de palco. Na sequência de imagens, a seguir, a aluna-atriz que interpreta a personagem Socorro faz uso conjunto de múltiplas semioses: ao varrer (ação, movimento), ao dançar (expressão corporal) e ao cantar (modulação da voz). 


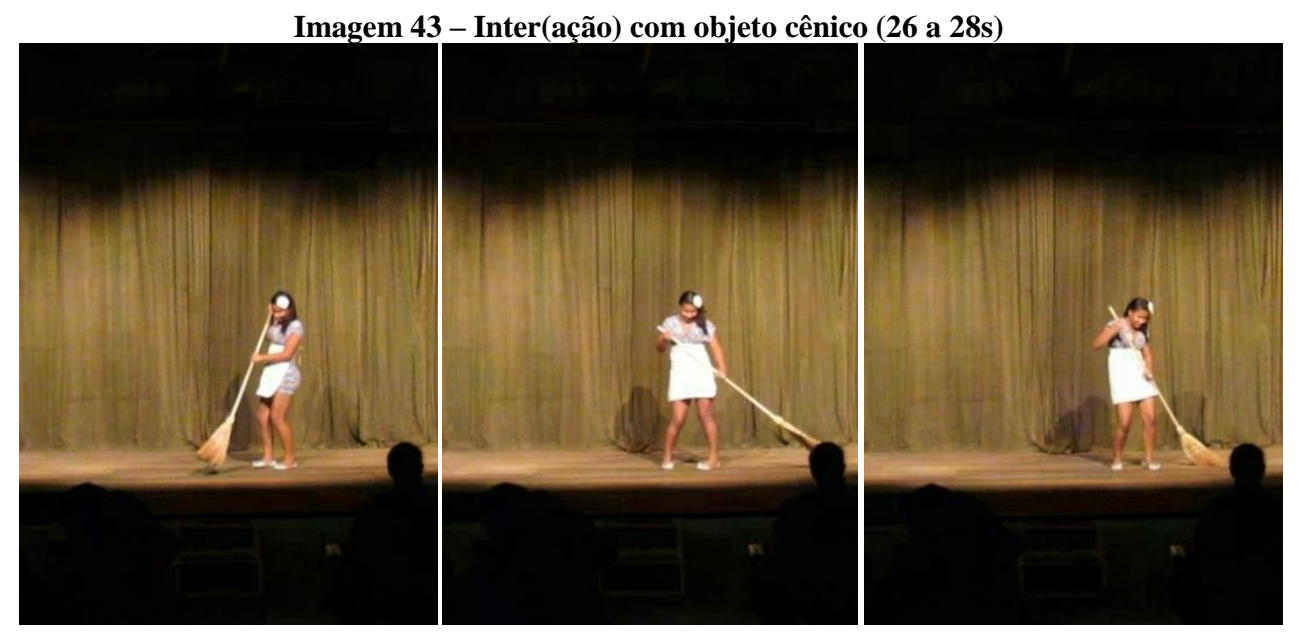

Os alunos-atores também interagiram com o cenário. Enquanto eles aguardavam os convidados chegarem à festa, suas personagens avó, pai, mãe e irmã das gêmeas (dispostas, na Imagem 44, a seguir, da esquerda para direita) arrumavam a mesa de aniversário:

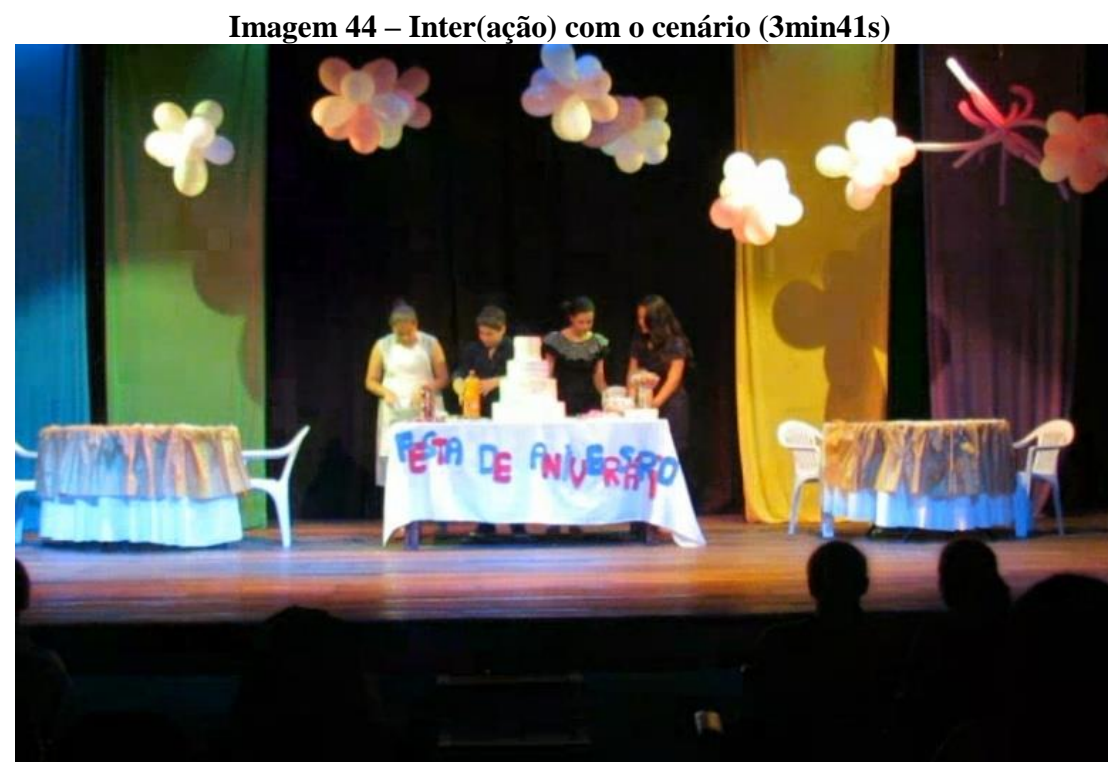

A inter(ação) entre personagens pode ser exemplificada na reconciliação entre o casal, depois da discussão em torno do sabor do bolo. A aluna-atriz que interpretou Kássia (a mãe das aniversariantes) busca se desculpar com Joaquim (seu marido), ao se movimentar, com a intenção de abraçá-lo (Imagem 45): 


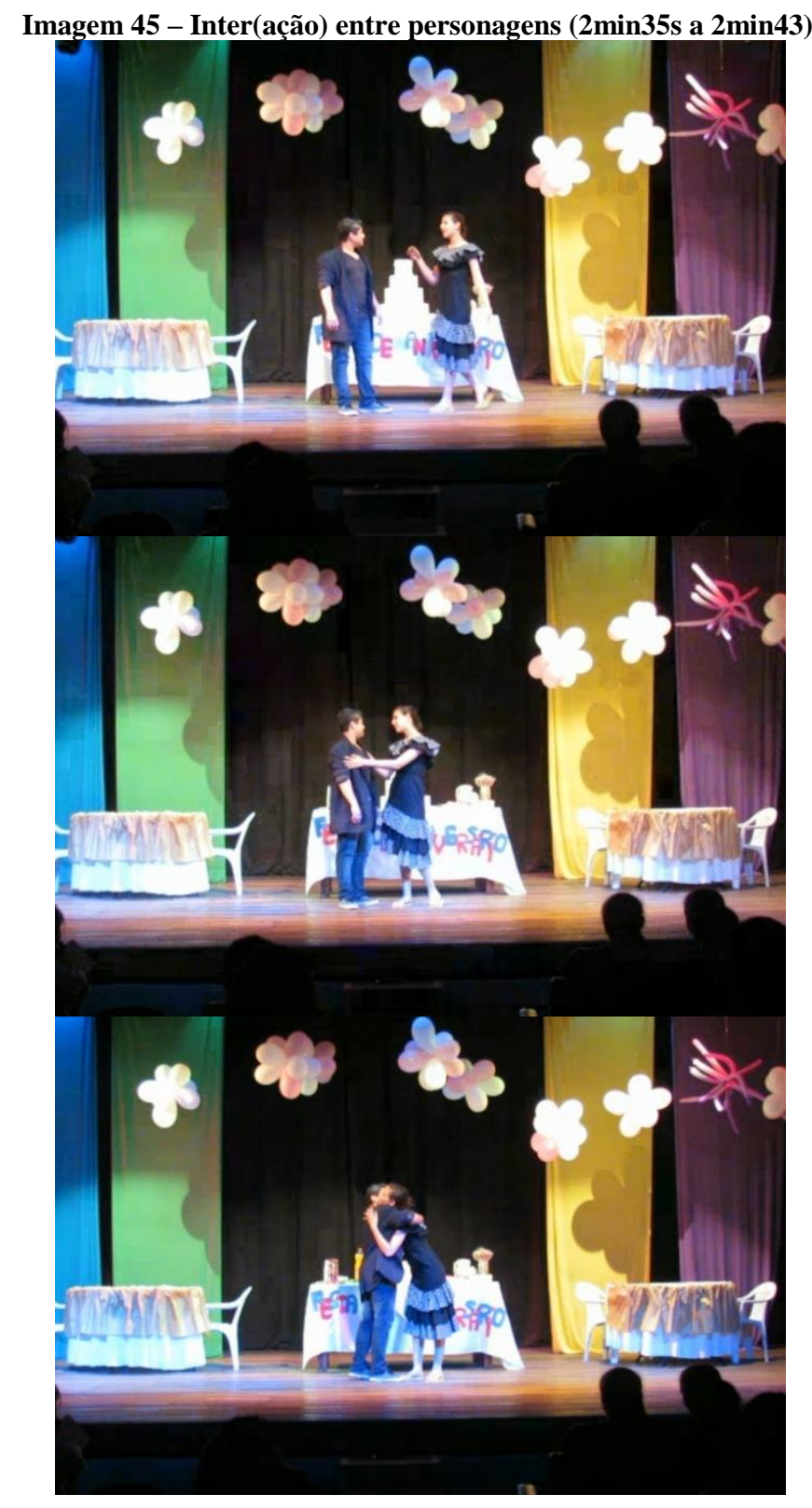

Destacamos a movimentação das alunas-atrizes que ocorre quando as amigas e a irmã da aniversariante se dão conta da presença de Verônica na festa (a convidada intrusa); todas as alunas-atrizes se dirigem a ela e se posicionam no centro do palco (Imagem 46): 


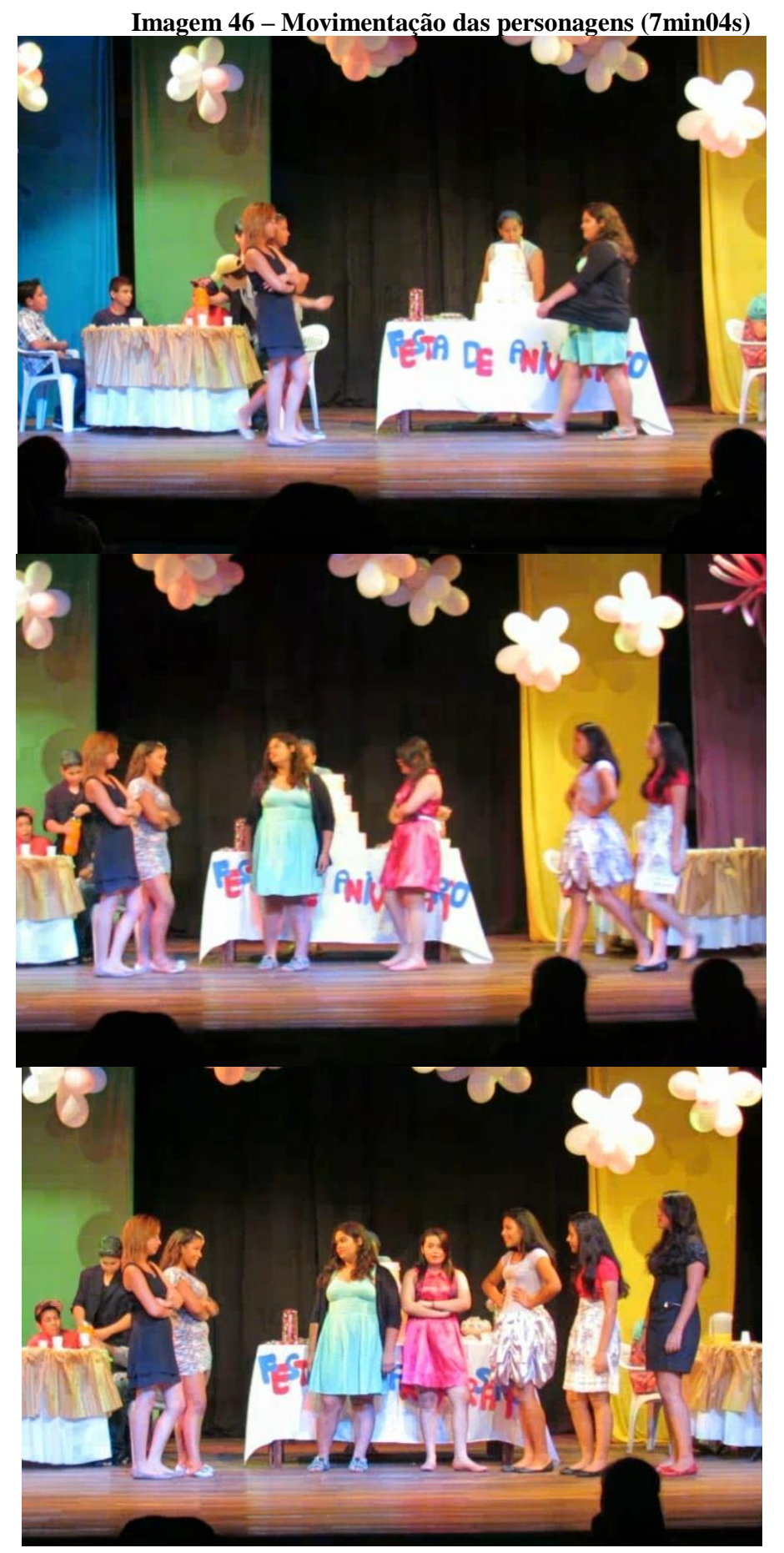

Conforme assegura Bentes (2010), a produção oral diz respeito ao fato de que a fala é emoldurada tanto pela maneira como são pronunciados determinados sons quanto pela maneira como o fluxo da fala é produzido (pausas, entonação, qualidade da voz, ritmo, velocidade, entre outros). Além disso, a autora observa que a complexidade da produção oral está relacionada a um conjunto de linguagens que co-ocorrem ao mesmo tempo em que 
falamos: gestualidade, expressão facial e direcionamento do olhar etc. Os recortes da produção oral dos alunos participantes desta pesquisa-ação, descritos anteriormente, apontam para esse fato. Houve combinação de recursos prosódicos (uso da voz e de suas modalizações), que possibilitou aos alunos-atores enfatizarem/valorizarem as intenções de suas personagens, diante das situações encenadas, associado ao uso de gestos/expressões corporais, que amplificou/reforçou o modo como os alunos-atores quiseram mostrar em relação ao que as personagens sentiam em determinados momentos da história.

Na produção de um gênero discursivo oral, a utilização de múltiplas semioses ocorre de modo "orquestrado", como propõe Gomes-Santos (2012), isto é, realiza-se de modo combinado, simultâneo, interdependente e relaciona-se aos propósitos comunicativos/interacionais do gênero. Em nosso caso, parece-nos possível afirmar que a natureza multimodal do texto dramático oralizado/representado convocou o uso do corpo (expressão da face, direcionamento do olhar etc.) para conduzir as interações entre as personagens e seus objetivos de cena. As ações e movimentações dos alunos-atores em toda a encenação parecem acompanhar a dinamicidade/complexidade requerida no uso dessas semioses para produção desse gênero: interação entre personagens, entre personagem e objeto cênico, entre personagem e cenário.

A observação dos exemplos destacados permite-nos entender que a relevância em se discutir o uso desses recursos semióticos consiste, especialmente, da relação que eles estabelecem entre si e - ao mesmo tempo - da relação que seu uso conjunto oferece para a produção dos sentidos dessa prática discursiva (representação cênica). Em outras palavras, no texto dramático oralizado, a multimodalidade convocada para a cena revelou-se por meio da interação/imbricação de alunos-atores e suas personagens e daqueles com um espaço particularizado - o palco. 


\subsection{Resultados das análises}

As atividades aplicadas no decorrer desta pesquisa-ação oportunizaram aos alunos a experimentação do gênero discursivo texto dramático. A proposta da sequência didática não teve por objetivo formar atores/atrizes, mas dar oportunidade de apreensão de práticas de linguagem que engendram nosso objeto de estudo - marcado fundamentalmente por sua esfera de circulação (teatral) -, para que os saberes necessários à produção/recepção do texto dramático pudessem ser vivenciados pelos alunos. Nesse sentido, buscamos conduzir atividades que apontassem para interdependência constitutiva de texto dramático e representação cênica. A produção final dos alunos (escrita e oralizada) possibilita-nos afirmar que eles apreenderam o gênero texto dramático, ao produzi-lo com propriedade.

Destacamos o cuidado deste estudo com relação ao desenvolvimento da competência linguístico-discursiva dos alunos-dramaturgos, a partir da abordagem de conteúdos relacionados às condições de produção do gênero proposto. Ao escrever o texto dramático, houve pertinência no reconhecimento/emprego de sequências dialogais e descritivas, de recursos gráficos (pontuação, alongamento de vogais, caixa alta etc.), para evidenciar os modos de falar/movimentar das personagens, indicar a mudança de cena e atribuir títulos a elas. Salientamos, também, a possibilidade de ampliação da competência genérica dos alunosleitores-espectadores, a partir do reconhecimento e apreensão do gênero discursivo texto dramático escrito/oralizado (assistir a um espetáculo teatral, ler textos dramáticos). Além disso, a experimentação das multimodalidades, no que diz respeito à produção oral desse gênero (modos de falar, agir e interagir das personagens) oportunizou o desenvolvimento das competências interativa, comunicativa e expressiva dos alunos-atores. Com isso, entendemos, assim como Koch $(2009$, p.55), que o

[...] ensino dos gêneros seria, pois, uma forma concreta de dar poder de atuação aos educadores e, por decorrência, aos seus educandos. Isso porque a maestria textual requer - muito mais que os outros tipos de maestria - a intervenção ativa de formadores e o desenvolvimento de uma didática específica. 
Nesse sentido, nossa atuação didática buscou possibilitar aos alunos o desenvolvimento de práticas discursivas escolares relacionadas a práticas teatrais, para que pudessem, assim, dominá-las como elas realmente são, já que, como assegura Marcuschi (2011, p.20), "quando ensinamos a operar com um gênero, ensinamos um modo de atuação sociodiscursiva numa cultura e não um simples modo de produção textual". 


\section{CONCLUSÃO}

O aparato teórico apresentado nesta pesquisa - estudos teatrais e multimodalidade buscou assegurar a dupla acepção de texto dramático defendida em nossa proposta de escolarização desse gênero discursivo: texto escrito para o teatro, texto efetivamente oralizado; dito de outro modo, texto escrito como estruturante da representação cênica, representação cênica como estruturada pelo texto escrito. Essa relação de interdependência constitutiva ajudou-nos a evidenciar sua natureza multimodal: texto que entrelaça voz e ação para a produção de sentidos e que mantém relações intrínsecas entre as modalidades falada e escrita da língua.

Constituiu-se, assim, primeiro objetivo deste trabalho descrever e problematizar a natureza multimodal do texto dramático. As discussões teóricas permitiram-nos compreender que a produção de um texto dramático (escrito ou oralizado) e sua recepção (leitura literária, dramática ou espetacular) constrói-se de modo multissemiótico e, nesse processo, há:

- tratamento linguístico diferenciado para a palavra escrita, pois esta é, desde o início, projetada para o palco (presença de diálogos e rubricas, alternância entre sequências conversacionais e descritivas);

- tipo de leitura que se instaura na imaginação do leitor e que prevê, de antemão, uma teatralidade inerente (possibilidades de interlocução específicas) ou de outras que implicam inflexões e modulações de voz (leitura dramática);

- presença simultânea de atores que falam, inter(agem), movimentam-se em cena, em meio a cenários, luzes e sons e de espectadores que assistem, ouvem, avaliam e interagem.

A partir da concepção de texto dramático como gênero discursivo multimodal, buscamos observar os desafios decorrentes da complexidade de se considerar esse gênero como objeto de ensino de língua materna. Da observação dos livros didáticos de língua portuguesa, apreendemos a coexistência de diferentes concepções de texto dramático (texto 
para ser lido, incluindo-o, assim, na esfera literária; ou texto para ser encenado, reconhecendo-o na esfera teatral), por meio de possibilidades diversas: imersão dos alunos no contexto de produção do gênero, a partir de atividades alocadas nas páginas de abertura dos capítulos (jogos teatrais); estudo/análise de textos de referência (fragmentos do cânone literário, principalmente) e da observação de uma estrutura composicional singular (habitual ausência do narrador, cenas, diálogos, rubricas); propostas de produção escrita (criação de rubricas, esquemas e cenas, adaptação de textos narrativos em textos teatrais) e de produção oral (improvisações, leituras dramáticas, encenações).

Acreditamos que a descrição minuciosa das unidades didáticas selecionadas nesta pesquisa, em relação a procedimentos que caracterizam as atividades de leitura, escrita e oralidade do texto dramático, possa contribuir para os estudos que buscam redimensionar, repensar e ressignificar o ensino de língua com base nos gêneros discursivos.

Os estudos efetuados a partir da interpretação dos dados levantados em questionários aplicados a professores de língua materna e alunos ajudaram-nos a nos aproximar da faceta escolar desse gênero e a conhecer os modos pelos quais o texto dramático tem-se feito presente no ambiente escolar, do ponto de vista de quem ensina (respostas dos professores) e de quem aprende (respostas dos alunos). As análises evidenciaram algumas tensões, no que diz respeito à seleção de atividades e de competências requeridas para apreensão desse gênero, às finalidades da produção oral do texto dramático (socialização do grupo, dramatização de um texto literário ou fixação de conteúdos) e às disciplinas relacionadas a esse objeto de ensino (Língua Portuguesa - para leitura e escrita, Educação Física e Arte para produção oral).

A apreensão desse conjunto de dados integrou o segundo objetivo de nosso trabalho e configurou-se importante material para subsidiar a constituição de nossa pesquisa-ação. Balizou-nos a elaboração da sequência didática a concepção bakhtiniana da linguagem, no sentido de assumirmos texto dramático no ensino de língua portuguesa como prática histórica e socialmente engendrada pela esfera teatral. Calcados na contribuição teórico-metodológica dos pesquisadores genebrinos (SCHNEUWLY; DOLZ et alii, 2004) e na proposta modular para apreensão e produção/recepção de gêneros discursivos (LOPES-ROSSI, 2002, 2006, 2011, 2012), a sequência didática aplicada aos alunos do $8^{\circ}$ ano E do Colégio Estadual Rodrigues Alves oportunizou um estudo situado do texto dramático, por meio da proposição 
de usos da língua muito próximos das reais ocorrências/vivências desse gênero, propiciando, assim, a inter-relação entre escola, cultura e sociedade.

Quanto ao terceiro objetivo, a abordagem multimodal do texto dramático promoveu um alargamento dos saberes convocados para produção/recepção desse gênero discursivo. Ao elegermos uma linguagem intrinsecamente relacionada à atuação, uma "nova" concepção de leitura revelou-se diante da associação da materialidade linguística à representação cênica e "novas" condições de enunciação puderam ser apreendidas. Nesse sentido, a seleção e o encaminhamento das atividades da sequência didática (ir ao teatro, ler o texto a que assistiu e comparar essas produções, produzir o texto teatral que irá encenar, memorizar falas e se apresentar) compreenderam inúmeros desafios, caracterizados, sobremaneira, pela natureza multissemiótica do texto dramático, a qual exigiu interações específicas entre pesquisadora e alunos e engajamento destes à proposta apresentada.

Destacamos, de início, o desafio da flexibilização das atividades propostas, tendo em vista a adaptação do procedimento, em diversos momentos, diante das dificuldades encontradas na apreensão e produção do gênero (assistir/atuar, ler/escrever) e das situações instauradas (faltas e substituições de alunos, por exemplo).

Para implementação das atividades, contamos com o desafio de buscar materiais disponíveis e de adaptá-los ao espaço e tempo escolar. Houve disposição diferenciada da sala, elaboração de cronograma, preparação de cópias de textos de referência para atividades de leitura e reconhecimento das características do gênero, distribuição de folhas para produção coletiva do texto, preparação de novas cópias para as cenas produzidas, a fim de guiar a revisão colaborativa, digitação do texto completo e produção de cópias para conduzir os ensaios; organização de outros itens para produção do gênero e de sua circulação, que envolveu, de uma maneira ou outra, a comunidade escolar, como divulgação de cartazes, recolhimento de autorizações dos pais, articulação de local para apresentação (teatro) e meio de transporte (ônibus).

Consideramos, ainda, o fato de os alunos assistirem a uma peça teatral em um teatro da cidade e observarem a construção textual que sustenta tal espetáculo constituiu-se dispositivo didático diferenciado (e desafiador) para a discussão das relações de texto dramático escrito e texto dramático oralizado/representado e das multimodalidades aí implicadas. 
A apreensão do gênero também se constituiu desafiadora. Quanto às práticas discursivas, os alunos realizaram interativamente: planejamento da produção escrita, produção coletiva de sinopses e cenas, correção colaborativa, leituras dramáticas, ensaios, organização do espetáculo, divulgação da peça e interpretação de personagens. Nessa direção, a proposta de escolarização do texto dramático, no bojo da esfera teatral e em sua acepção multimodal, revelou-se positiva para o acesso ao conhecimento pela experiência com a linguagem e com o corpo e pela apreensão dos saberes na confluência de práticas intergenéricas: ir ao teatro (conhecer seu espaço, assistir a uma peça, conversar com estudantes-atores), efetuar tipos de leitura dramática, escrever falas e rubricas, debater a escolha de personagens, tema, músicas, memorizar texto, ensaiar, avaliar a atuação dos colegas-atores, produzir cartazes e programas, atuar, improvisar, receber os aplausos dos colegas-espectadores.

A sequência didática permitiu, ainda, um espaço de aprendizagem e de usos da linguagem que podemos entender como produtivo para que se instaure essa prática escolar que não abrange somente as características e relações fala-escrita, mas que também observa como se caracteriza a linguagem gestual/corporal, tão importante na constituição do sentido, ampliando, assim, as competências dos alunos: genérica (apreender o gênero escrito e oral) interacional (planejar produção escrita, criar personagens, ensaiar etc.), linguístico-discursiva (criar falas, rubricas, cenas, títulos), comunicativa e expressiva (ler, escrever, atuar, assistir).

Concluímos, dessa maneira, que a escolarização do texto dramático é desafiadora por permitir o vínculo entre estrutura e ação, entre linguagem e corpo, entre saber e prática. A pesquisa-ação atesta o fato de que promover o estudo/a produção/recepção do texto dramático no contexto de ensino e aprendizagem de língua portuguesa constitui-se tarefa complexa. Em meio aos desafios enfrentados, a aplicação da sequência didática revelou que a forma escolar (escritural) se mantém assegurada, pois as atividades para a apreensão do gênero discursivo texto dramático configuraram-se essencialmente escolares: explicação do texto a ser lido ou da peça a ser apresentada, leitura de textos para subsidiar a produção escrita, correção das cenas produzidas, registro de informações no quadro de giz, fixação de conteúdos, tarefa para casa ou para as férias, entre outras. A partir do exposto, entendemos que nossa hipótese se confirma.

Com isso, salientamos que a apreensão e a produção (complexa e desafiadora) do texto dramático demandam a realização e o investimento de muitas modalidades, das quais compreendemos convocar um tipo específico de linguagem - a linguagem teatral. 
Quanto ao desenvolvimento dos Módulos Didáticos, a pesquisa-ação alcançou, de modo particular, a ampliação do repertório cultural dos alunos - ao promover à ida ao teatro e do processo criativo na produção escrita do gênero (livre de adaptações literárias) e de sua circulação (colegas-espectadores assistiram à peça, receberam também o texto escrito).

Tendo em vista as contribuições teóricas dos estudos teatrais e nossa experiência com o teatro, os procedimentos apresentados na sequência didática configuram-se sugestões que podem auxiliar o professor de língua portuguesa a retomar, adaptar e reinventar essa experiência em diferentes oportunidades de ensino e aprendizagem: planejar a produção escrita, efetuar leitura dramática, mediar a escolha de personagens, encaminhar a construção de personagens, conduzir ensaios, dirigir cenas, aplicar jogos teatrais, orientar marcações de sonoplastia etc.

Esta pesquisa buscou, finalmente, somar-se aos estudos teórico-metodológicos para o ensino de gêneros, de forma a preencher uma lacuna didática, no que diz respeito à seleção de gêneros para discussão no campo científico, ao apresentar uma proposta de aplicação do texto dramático (escrito e oralizado/representado) nos anos finais do ensino fundamental. Constituía objetivo geral deste trabalho contribuir para o aprofundamento dos estudos voltados à Linguística Aplicada no que concerne a sua associação com a Arte e o ensino de língua portuguesa; nesse sentido, podemos dizer que foi alcançado, uma vez que a pesquisa apontou para inter-relação de estudos dos multiletramentos/e da multimodalidade e escolarização de gêneros e para formação do professor de língua, na sua correlação com as artes cênicas.

O teatro assume, pois, um lugar privilegiado na história da produção cultural da humanidade. Antes mesmo de existir como realização escrita, os homens primitivos o faziam em rituais sagrados e as crianças o usavam como brincadeira (CHACRA, 2010). Expressão artística por excelência que se renova, reinventa-se e atualiza-se, das festas dionisíacas às atividades sócio-educativas, de efeito cartártico e transformador, o teatro apresenta-se como arte inerente às relações humanas e, neste percurso: da vida para a escola, da escola para a sala de aula, da sala de aula para a disciplina Língua Portuguesa é que buscamos, finalmente, inter(agir). 


\section{REFERÊNCIAS}

ARISTÓTELES. A poética clásica. São Paulo: Cultrix, 2005.

BAJTÍN, Mikhail Mikhălovich; MEDVEDEV, Pavel Nikolaevich. El método formal em los estudios literarios. Introducción crítica a una poética sociológica. Trad. Tatiana Bubnova. Madrid: Alianza Editorial, 2003[1928].

BAKHTIN, Mikhail Mikhaŭlovich. Estética da criação verbal. Trad. Paulo Bezerra. São Paulo: Martins Fontes, 2003[1979].

- Problemas da Poética de Dostoiévski. Trad. Paulo Bezerra. São Paulo: Forense Universitária, 2005[1928].

; VOLOCHÍNOV, Valentin Nikolaévitch. Marxismo e filosofia da linguagem: Problemas fundamentais do método sociológico na Ciência da Linguagem. Trad. Michel Lahud e Yara Frateschi Vieira e colaboradores. 9.ed. São Paulo: Hucitec, 2002[1929].

BARROS, Diana Luz Pessoa de. Entre a fala e a escrita: algumas reflexões sobre as posições intermediárias. In: PRETI, Dino (Org.). Fala e Escrita em questão. Projetos Paralelos NURC/SP, 2.ed. São Paulo: Humanitas, 2001.

BARROS, Eliana Merlin Deganutti; NASCIMENTO, Elvira Lopes. Gêneros textuais e livro didático da teoria à prática. Linguagem em (Dis)curso. Tubarão, v.7, n.2, mai./ago., 2007, p.241-270.

BATISTA, Antônio Augusto Gomes. Avaliação dos livros didáticos: para entender o Programa Nacional do Livro Didático. In: ROJO, Roxane Helena Rodrigues; BATISTA, Antônio Augusto Gomes (Orgs.). Livro didático de Língua Portuguesa, Letramento e Cultura da Escrita. Campinas, SP: Mercado de Letras, 2003, p.25-67.

; ROJO, Roxane Helena Rodrigues; ZÚÑIGA, Nora Cabrera. Produzindo livros didáticos em tempo de mudança. In: VAL, Maria da Graça Costa; MARCUSCHI, Beth (Orgs.). Livros didáticos de língua portuguesa: letramento e cidadania. Belo Horizonte: Ceale; Autêntica, 2008, pp.47-72.

BENTES, Anna Christina. Linguagem oral no espaço escolar: rediscutindo o lugar das práticas e dos gêneros orais na escola. In: RANGEL; Egon de Oliveira; ROJO, Roxane Helena Rodrigues (Orgs.). Língua Portuguesa: ensino fundamental. Coleção Explorando o Ensino, v.19. Brasília: Ministério da Educação, Secretaria de Educação Básica, 2010, p.129154.

BOAL, Ausgusto. Teatro do Oprimido e Outras Poéticas Políticas. 10.ed. rev. e ampliada. Rio de Janeiro: Civilização Brasileira, 2010. 
BRAIT, Beth. Bakhtin e a natureza constitutivamente dialógica da linguagem. In: BRAIT, Beth (Org.). Bakhtin: dialogismo e construção do sentido. 2.ed. Campinas, SP: Editora da UNICAMP, 2005, p.87-98.

BRASIL. Parâmetros Curriculares Nacionais de língua portuguesa: terceiro e quarto ciclos do ensino fundamental. Brasília: MEC, 1998.

Guia de livros didáticos: PNLD 2011-2013. Língua Portuguesa. Brasília: Ministério da Educação, Secretaria de Educação Básica, 2010.

BRITO, Eliana Vianna. O ensino das estratégias de leitura. In: SILVA, Elisabeth Ramos da (Org.). Texto \& Ensino. Taubaté, SP: Cabral Editora e Livraria Universitária, 2002, p.83-109.

BUNZEN, Clecio (2009). O livro didático de português como gênero do discurso: implicações teóricas e metodológicas. Disponível em: http://www.letramento.iel.unicamp.br/portal/wp-content/uploads/2009/07/artigo_clecio.pdf.

Acesso em: julho de 2013.

CAFIERO, Delaine; CORRÊA, Hércules Tolêdo. Os textos literários em quatro coleções de livros didáticos: entre o estético e o escolar. In: ROJO, Roxane; BATISTA, Antônio Augusto Gomes (Orgs.). Livro didático de Língua Portuguesa, Letramento e Cultura da Escrita. Campinas, SP: Mercado de Letras, 2003, p.277-298.

CALZAVARA, Rosemari Bendlin. Encenar e ensinar o texto dramático na escola. Revista Científica da FAP. Curitiba, v.4, n.2, jul./dez., 2009, p.149-154.

COPE, Bill; KALANTZIS, Mary (Ed.). Multiliteracies: Literacy Learning and the Design of Social Futures. Routledge: Psychology Press, 2000.

CORRÊA, Manoel Luiz Gonçalves. O modo heterogêneo de constituição da escrita. São Paulo: Martins Fontes, 2004.

COSTA-HÜBES, Terezinha da Conceição; SIMIONI, Claudete Aparecida. Sequência Didática: uma proposta metodológica curricular de trabalho com os gêneros discursivos/textuais. In: BARROS, Eliana Merlin Deganutti de; RIOS-REGISTRO, Eliane Segati (Orgs.). Experiências com sequências didáticas de gêneros textuais. Campinas, SP: Pontes Editores, 2014, p.15-39.

CRISTÓVÃO, Vera Lúcia Lopes; NASCIMENTO, Elvira Lopes. Gêneros textuais e ensino: contribuições do interacionismo sociodiscursivo. In: KARWOSKI, Acir Mário; GAYDECZKA, Beatriz; BRITO, Karim Siebeneicher (Orgs.). Gêneros textuais reflexões e ensino. 4.ed. São Paulo: Parábola, 2011, p.33-52.

CHACRA, Sandra. Natureza e sentido da improvisação teatral. 2.ed. São Paulo: Perspectiva, 2010.

DESGRANDES, Flávio. A posição do espectador: perspectivas pedagógicas. In: TELLES, Narciso; FLORENTINO, Adilson (Orgs.). Cartografias do ensino do teatro. Uberlândia: UFU, 2009, p.85-93. 
DIEGUES, Filomena Maria Brasil Cabral. O texto dramático em contexto de sala de aula proposta para uma nova abordagem. $87 \mathrm{f}$. Dissertação (Mestrado). Faculdade de Letras da Universidade do Porto, Porto, 2010.

DIONISIO, Angela Paiva. Gêneros textuais e multimodalidade. In: KARWOSKI, Acir Mário; GAYDECZKA, Beatriz; BRITO, Karim Siebeneicher (Orgs.). Gêneros textuais reflexões e ensino. 4.ed. São Paulo: Parábola, 2011, p.137-152.

DOLZ, Joaquim; NOVERRAZ, Michèle; SCHNEUWLY, Bernard. Sequências didáticas para o oral e a escrita: apresentação de um procedimento. In: SCHNEUWLY, Bernard; DOLZ, Joaquim (Orgs.). Gêneros orais e escritos na escola. Trad. e Org. Roxane Helena Rodrigues Rojo e Glaís Sales Cordeiro. Campinas: Mercado de Letras, 2004, p.81-108.

; SCHNEUWLY, Bernard. Gêneros e progressão em expressão oral e escrita elementos para reflexões sobre uma experiência suíça (francófona). In: SCHNEUWLY, Bernard; DOLZ, Joaquim (Orgs.). Gêneros orais e escritos na escola. Trad. e Org. Roxane Helena Rodrigues Rojo e Glaís Sales Cordeiro. Campinas: Mercado de Letras, 2004, p.35-60.

; HALLER, Sylvie. O oral como texto: como construir um objeto de ensino. In: SCHNEUWLY, Bernard; DOLZ, Joaquim (Orgs.). Gêneros orais e escritos na escola. Trad. e Org. Roxane Helena Rodrigues Rojo e Glaís Sales Cordeiro. Campinas: Mercado de Letras, 2004, p.125-155.

DONEGÁ, Ana Laura; SILVA, Bruna Grasiela da; IEMMA, Cecília Pinhata; COUTINHO, Julia Alves. Primeiro ato: uma introdução ao teatro em cinco cenas. In: Língua, Literatura e Ensino, São Paulo, v.IV, mai./2009, p.239-245.

FARACO, Carlos Aberto. Linguagem \& diálogo: as idéias linguísticas do círculo de Bakhtin. São Paulo: Parábola, 2009.

FÁVERO, Leonor Lopes; ANDRADE, Maria Lúcia da Cunha Victorio de Oliveira; AQUINO, Zilda Gaspar Oliveira de. Oralidade e escrita: perspectivas para o ensino de língua materna. 3.ed. São Paulo: Cortez, 2002.

FIORIN, José Luiz. As astúcias da enunciação. As categorias de pessoa, espaço e tempo. São Paulo: Ática, 1996.

Introdução ao pensamento de Bakhtin. São Paulo: Editora Ática, 2011.

FRANCO, Maria Amélia Santoro. A pedagogia da pesquisa-ação. Educação e Pesquisa. São Paulo, v.31, n.3, dez., 2005, p.483-502.

GANCHO, Cândida Vilares. Como analisar narrativas. São Paulo: Ática, 2002.

GERALDI, João Wanderley. O texto na sala de aula. 5.ed. São Paulo: Ática, 2011[1984].

A produção dos diferentes letramentos. Bakhtiniana. São Paulo, 9 (2), , ago./dez., 2014, p.25-34. 
GOMES-SANTOS, Sandoval Nonato. Recontando histórias na escola. Gêneros discursivos e produção da escrita. São Paulo: Martins Fontes, 2003.

. A questão do gênero no Brasil: teorização acadêmico-científica e normatização oficial. 251 f. Tese (Doutorado). Universidade Estadual de Campinas, Instituto de Estudos da Linguagem, Campinas, 2004.

A exposição oral nos anos iniciais do ensino fundamental. São Paulo: Cortez, 2012.

GRANERO, Vic Vieira. Como usar o teatro na sala de aula. São Paulo: Contexto, 2011.

GRÉSILLON, Almuth. Nos limites da gênese: da escritura do texto de teatro à encenação. In: Estudos Avançados. São Paulo, v.9, n.23, 1995, p.269-285.

GUIMARÃES, Ana Maria de Mattos; CAMPANI-CASTILHOS, Daiana; DREY, Rafaela Fetzner. Gêneros de texto no dia-a-dia do ensino fundamental. São Paulo: Mercado de Letras, 2008.

HAUER, Rafael Maurício. Linguagem teatral e a aquisição de conteúdos escolares: uma perspectiva cultural e histórica. 267 f. Dissertação (Mestrado). Universidade Federal do Paraná, Curitiba, 2005.

HELBO, André. Teoría del espetáculo. El paradigma espetacular. Buenos Aires: Galerna, 1989.

Ressignificando a aula de leitura a partir dos gêneros textuais. In: NASCIMENTO, Elvira Lopes (Org.). Gêneros textuais: da didática das línguas aos objetos de ensino. São Carlos: Claraluz, 2009, p.151-194.

ITURBE, Teresa. Teatro para representar na Escola. Trad. Silvia Massimini. São Paulo: Madras, 2007.

JAPIASSU, Ricardo Ottoni Vaz. Metodologia do ensino de teatro. Campinas, SP: Papirus, 2001.

A linguagem teatral na escola: pesquisa, docência e prática pedagógica. Campinas, SP: Papirus, 2007.

JEWITT, C. Multimodality and literacy in school classrooms. Review of Research in Education, Thousand Oaks, v.32, n.1, 2008, p.241-267.

KATO, Mary. No mundo da escrita: uma perspectiva psicolinguística. São Paulo: Ática, 1986.

KERBRAT-ORECCHIONI, Catherine. Pour une approche pragmatique du dialogue théâtral. Pratiques. n.41, mars., 1984, p.46-62.

KLEIMAN, Angela Del Carmen Bustos Romero de. Modelos de letramento e as práticas de alfabetização na escola. In: KLEIMAN, Angela Del Carmen Bustos Romero de (Org.). Os 
significados do letramento: uma nova perspectiva sobre a prática social da escrita. Campinas, SP: Mercado de Letras, 1995, p.15-61. $\overline{\text { p.72-91. }}$

Letramento na contemporaneidade. Bakhtiniana. São Paulo, 9 (2), ago./dez., 2014,

KOCH, Ingedore Villaça. A inter-ação pela linguagem. 10.ed. São Paulo: Contexto, 2007. O texto e a construção dos sentidos. 9.ed. São Paulo: Contexto, 2008.

Desvendando os segredos do texto. 6.ed. São Paulo: Cortez, 2009.

; ELIAS, Vanda Maria. Ler e compreender os sentidos do texto. 3.ed. São Paulo: Contexto, 2012.

KOUDELA, Ingrid Dormien. Texto e Jogo: uma didática brechtiana. São Paulo: Perspectiva, 2010 .

KRESS, Gunther. Multimodality. In: COPE, Bill; KALANTZIS, Mary. (Ed.). Multiliteracies: Literacy Learning and the Design of Social Futures. Routledge: Psychology Press, 2000, p.179-199.

LIBÂNEO, José Carlos. Didática. São Paulo: Cortez, 1994.

LISBÔA, Eliane. A teatralidade do texto dramático. Urdimento. Revista de Estudos sobre Teatro da América Latina. Santa Catarina, v.2, 1998, p.22-40.

LOPES-ROSSI, Maria Aparecida Garcia. O desenvolvimento de habilidades de leitura e de produção de textos a partir gêneros discursivos. In: LOPES-ROSSI, Maria Aparecida Garcia (Org.). Gêneros discursivos no ensino de leitura e produção de textos. Taubaté, SP: Cabral Editora e Livraria Universitária, 2002a.

A produção de texto escrito na escola a partir de gêneros discursivos. In: SILVA, Elisabeth Ramos da (Org.). Texto \& Ensino. Taubaté, SP: Cabral Editora e Livraria Universitária, 2002b, p.133-159.

- (2002c). A produção escrita a partir de gêneros discursivos: da elaboração à realização de projetos pedagógicos. Disponível em: http://www.gel.org.br/estudoslinguisticos/volumes/32/htm/comunica/cc048.htm. Acesso em: julho de 2013.

Procedimentos para estudo de gêneros discursivos da escrita. Revista Intercâmbio. v.XV, São Paulo: LAEL/PUC-SP, 2006.

Gêneros discursivos no ensino de leitura e produção de textos. In: KARWOSKI, Acir Mário; GAYDECZKA, Beatriz; BRITO, Karim Siebeneicher (Orgs.). Gêneros textuais reflexões e ensino. 4.ed. São Paulo: Parábola, 2011, p.69-82. 
A produção escrita de gêneros discursivos em sala de aula: aspectos teóricos e sequência didática. Revista Signum: Estudos da Linguagem, Londrina, n.15/3, dez., 2012, p.223-245.

LÜDKE, Menga; ANDRÉ, Marli Elisa Dalmazo Afonso de. Pesquisa em educação: abordagens qualitativas. São Paulo: EPU, 1986.

MACHADO, Anna Rachel; CRISTÓVÃO, Vera Lúcia Lopes. A construção de modelos didáticos de gêneros: aportes e questionamentos para o ensino de gêneros. In: MACHADO, Anna Rachel; ABREU-TARDELLI, Lília Santos; CRISTÓVÃO, Vera Lúcia Lopes (Orgs.). Linguagem e educação: o ensino e a aprendizagem de gêneros textuais. Campinas: Mercado de Letras, 2009, p.123-151.

; GUIMARÃES, Ana Maria de Mattos. O interacionismo sociodiscursivo no Brasil. In: MACHADO, Anna Rachel; ABREU-TARDELLI, Lília Santos; CRISTÓVÃO, Vera Lúcia Lopes (Orgs.). Linguagem e educação: o ensino e a aprendizagem de gêneros textuais. Campinas: Mercado de Letras, 2009, p.17-42.

MACHADO, Maria Clara. Teatro para crianças. In: Cadernos de Teatro. Publicação d'O Tablado patrocinada pelo Serviço Nacional de Teatro - DAC - FUNARTE, MEC, n.80, jan./fev./mar., 1979, p.1-10.

MAGALDI, Sábato. Iniciação ao teatro. 6.ed. São Paulo: Ática, 1997.

MARCUSCHI, Luiz Antônio. A repetição na língua falada como estratégia de formulação textual. In: KOCH, Ingedore Villaça (Org.). Gramática do Português Falado. v.VI. 2.ed. rev. Campinas: Editora da Unicamp, 2002, p.105-141.

Da fala para a escrita: atividades de retextualização. 4.ed. São Paulo: Cortez, 2003.

Oralidade e ensino de língua: uma questão pouco "falada". In: DIONISIO, Angela Paiva; BEZERRA, Maria Auxiliadora (Orgs.). O livro didático de Português: múltiplos olhares. 3.ed. Rio de Janeiro: Lucerna, 2005, p.21-34.

. Produção textual, análise de gêneros e compreensão. São Paulo: Parábola, 2008, p.146-225.

Gêneros textuais: definição e funcionalidade. In: DIONISIO, Angela Paiva; MACHADO, Anna Rachel; BEZERRA, Maria Auxiliadora (Orgs.). Gêneros textuais \& ensino. São Paulo: Parábola, 2010, p.19-38.

Gêneros textuais: configuração, dinamicidade e circulação. In: KARWOSKI, Acir Mário; GAYDECZKA, Beatriz; BRITO, Karim Siebeneicher (Orgs.). Gêneros textuais reflexões e ensino. 4.ed. São Paulo: Parábola, 2011, p.17-31.

MATENCIO, Maria de Lourdes Meirelles. Textualização, ação e atividade: reflexões sobre a abordagem do interacionismo sociodiscursivo. In: GUIMARÃES, Ana Maria de Mattos; MACHADO, Anna Rachel; COUTINHO, Antónia (Orgs.). O interacionismo sociodiscursivo questões epistemológicas e metodológicas. Campinas: Mercado de Letras, 2007, p.51-63. 
MELLO, Renato de. Teatro, gênero e análise do discurso. In: MACHADO, Ida Lucia Machado; MELLO, Renato (Orgs.). Gêneros: reflexões em Análise do Discurso. Belo Horizonte: NAD/FALE/UFMG, 2004, p.87-106.

MENDONÇA, Márcia Rodrigues de Souza. Pontuação e sentido: em busca da parceria. In: DIONISIO, Angela Paiva; BEZERRA, Maria Auxiliadora (Orgs.). O livro didático de Português: múltiplos olhares. 3.ed. Rio de Janeiro: Lucerna, 2005, p.113-125.

NASCIMENTO, Elvira Lopes do. Gêneros textuais: da didática das línguas aos objetos de ensino. São Carlos: Claraluz, 2009.

; ROJO, Roxane Helena Rodrigues. Gêneros de texto/discurso e os desafios da contemporaneidade. Campinas, SP: Pontes, 2014.

NAZARETH, Carlos Augusto. O texto teatral na formação do leitor. (2008) Disponível em: http://www.vertenteculturalteatroinfantil.blogspot.com.br/2008/07/o-texto-teatral.html.

Acesso em: julho de 2013.

PASCOLATI, Sônia Aparecida Vido. (2009). O texto dramático na sala de aula. Disponível em: http://alb.com.br/arquivomorto/edicoes_anteriores/anais17/txtcompletos/sem15/COLE_270.pdf. Acesso em: julho de 2013.

PAVIS, Patrice. Dicionário de teatro. 3.ed. Trad. Jacó Guinsburg e Maria Lúcia Pereira. São Paulo: Perspectiva, 2008.

A análise dos espetáculos: teatro, mímica, dança, dança-teatro, cinema. 2.ed. Trad. Sérgio Sálvia Coelho. São Paulo: Perspectiva, 2011.

PEIXOTO, Fernando. O que é teatro. São Paulo: Brasiliense, 1986.

PIETRO, Jean-Fraçois de; SCHNEUWLY, Bernard. O modelo didático do gênero: um conceito da engenharia didática. In: NASCIMENTO, Elvira Lopes. Gêneros Textuais: da didática das línguas aos objetos de ensino. 2.ed. Campinas, SP: Pontes Editores, 2014, p.5181 .

PLATÃO. A república. São Paulo: Nova Cultural, 1997.

PRETI, Dino. Apresentação. In: PRETI, Dino (Org.). Análise de textos orais. Projetos Paralelos - NURC/SP, 5.ed. São Paulo: Humanitas, 2001, p.11-12.

REVERBEL, Olga. Jogos teatrais na escola. Atividades globais de expressão. São Paulo: Scipione, 2007.

RODRIGUES, Paulo Cezar. Características do livro didático de língua portuguesa na mediação da produção textual escrita. 2007. 121 f. Dissertação (Mestrado) Programa de Pósgraduação em Letras, Universidade Estadual de Maringá, Maringá, 2007.

ROJO, Martín Rodríguez. Hacia una Didáctica crítica. Madrid: La Muralla, 1997. 
ROJO, Roxane Helena Rodrigues. Letramento escolar em três práticas: perspectivas para a multivocalidade. In: Revista ANPOLL, n.11, jul./dez., 2001, p.235-262.

O texto no ensino-aprendizagem de línguas hoje: desafios da contemporaneidade. In: TRAVAGLIA, Luiz Carlos; FINOTTI, Luisa Helena Borges; MESQUITA, Elisete Maria Carvalho de (Orgs.). Gêneros de texto: caracterização e ensino. Uberlândia: EDUFU, 2007, p.9-43.

Gêneros de discurso/Texto como objeto de ensino de línguas: um retorno ao trivium? In: SIGNORINI, Inês (Org.). [Re]discutir texto, gênero e discurso. São Paulo: Parábola, 2008, p.73-108.

Letramento(s): práticas de letramento em diferentes contextos. In: ROJO, Roxane Helena Rodrigues (Org.). Letramentos múltiplos, escola e inclusão social. São Paulo: Parábola, 2009, p.95-121.

Pedagogia dos multiletramentos. In: ROJO, Helena Rodrigues Roxane; MOURA, Eduardo (Orgs.). Multiletramentos na escola. São Paulo: Parábola, 2012, p.11-31.

Gêneros discursivos do Círculo de Bakhtin e multiletramentos. In: ROJO, Roxane Helena Rodrigues (Orgs.). Escol@ conectada: os multiletramentos e as TICs. São Paulo: Parábola, 2013, p.13-36.

A arquitetônica bakhtiniana e os multiletramentos. In: ROJO, Roxane Helena Rodrigues. NASCIMENTO, Elvira Lopes do; ROJO, Roxane Helena Rodrigues (Orgs.). Gêneros de texto/discurso e os desafios da contemporaneidade. Campinas, SP: Pontes, 2014, p.249-271.

; BARBOSA, Jacqueline Peixoto. Hipermodernidade, multiletramentos e gêneros discursivos. São Paulo: Parábola, 2015.

; MOURA, Eduardo. Multiletramentos na escola. São Paulo: Parábola, 2012.

ROSENFELD, Anatol. Prismas do teatro. São Paulo: Perspectiva, 1993.

ROSSETO, Robson. O espectador e a relação do ensino do teatro com o teatro contemporâneo. In: Revista Científica da FAP - Faculdade de Artes do Paraná, v.3, jan./dez. 2008, p.69-84.

ROUBINE, Jean-Jacques. A linguagem da encenação teatral. 2.ed. Trad. Yan Michalski. Rio de Janeiro: Zahar, 1998.

RYNGAERT, Jean-Pierre. Introdução à análise do teatro: leitura e crítica. Trad. Paulo Neves. Rev. Trad. Monica Stahel. São Paulo: Martins Fontes, 1995.

Jogar, representar: práticas dramáticas e formação. Trad. Cássia Raquel da Silveira. São Paulo: Cosac Naify, 2009.

SAINT-EXUPÉRY, Antoine de. O pequeno príncipe. Trad. Dom Marcos Barbosa. Rio de Janeiro: Agir, 2009. 
SAITO, Cláudia Lopes Nascimento; NASCIMENTO, Elvira Lopes. Texto, discurso e gênero. In: SANTOS, Annie Rose dos; RITTER, Lilian Cristina Buzato (Orgs.). O trabalho com a escrita no ensino fundamental. Formação de professores EAD, n.20, Maringá: EDUEM, 2005, p.11-41.

SCHNEUWLY, Bernard. A palavra e ficcionalização: um caminho para o ensino da linguagem oral. In: SCHNEUWLY, Bernard; DOLZ, Joaquim (Orgs.). Gêneros orais e escritos na escola. Trad. e Org. Roxane Helena Rodrigues Rojo e Glaís Sales Cordeiro. Campinas: Mercado de Letras, 2004, p.109-124.

Le travail enseignant. In: SCHNEUWLY, Bernard.; DOLZ, Joaquim (Orgs). Des objets enseignés en classe de français - Le travail de l'enseignant sur la rédaction de texts argumentatifs et sur la subordonnée relative. Rennes, FR: Presses Universitaires de Rennes, 2009b, p.29-43.

; DOLZ, Joaquim (Orgs.) et alii. Gêneros orais e escritos na escola. Trad. e Org.: Roxane Rojo e Glaís Sales Cordeiro. Campinas: Mercado de Letras, 2004.

SCHNEUWLY, Bernard; DOLZ, Joaquim. Os gêneros escolares - das práticas de linguagem aos objetos de ensino. In: SCHNEUWLY, Bernard; DOLZ, Joaquim (Orgs.). Gêneros orais e escritos na escola. Trad. e Org. Roxane Helena Rodrigues Rojo e Glaís Sales Cordeiro. Campinas: Mercado de Letras, 2004, p.61-78.

SILVA, Paulo Eduardo Mendes da; MORI-DE-ANGELIS, Cristiane Cagnoto. Livros didáticos de língua portuguesa $\left(5^{\mathrm{a}}\right.$ a $8^{\mathrm{a}}$ séries): perspectivas sobre o ensino da linguagem oral. In: ROJO, Roxane Helena Rodrigues; BATISTA, Antônio Augusto Gomes (Orgs.). Livro didático de Língua Portuguesa, Letramento e Cultura da Escrita. Campinas, SP: Mercado de Letras, 2003, p.185-209.

SOARES, Magda. Concepções de linguagem e o ensino da Língua Portuguesa. In: BASTOS, Neusa Barbosa (Org.). Língua Portuguesa. História, Perspectivas, Ensino. São Paulo: EDUC, 1998, p.53-60.

Novas práticas de leitura e escrita: letramento na cibercultura. In: Educação \& Sociedade. v.23, n.81. Campinas, dez., 2002, p.143-160.

Letramento: um tema em três gêneros. 3.ed. Belo Horizonte: Autêntica Editora, 2009.

SPOLIN, Viola. Jogos teatrais na sala de aula: um manual para o professor. 2.ed. São Paulo: Perspectiva, 2010.

STANISLAVSKI, Constantin. Manual do ator. Trad. João Azenha Júnior. 2.ed. São Paulo: Martins Fontes, 1997.

A preparação do Ator. Tradução: Pontes de Paula Lima. Rio de Janeiro: Civilização Brasileira, 2001[1936].

STREET, Brian Vincent. Literacy in theory and practice. Cambridge: Cambridge University Press, 1984. 
SUASSUNA, Ariano. Disponível em: http://revistaescola.abril.com.br/linguaportuguesa/pratica-pedagogica/ariano-suassuna-todo-professor-deve-ter-pouco-ator610096.shtml. Acesso em: fevereiro de 2015.

TEIXEIRA, Coelho. O que é ação cultural. São Paulo: Brasiliense, 2001.

TELLES, Narciso. As oficinas de teatro e a prática do artista-docente. In: TELLES, Narciso; FLORENTINO, Adilson (Orgs.). Cartografias do ensino do teatro. Uberlândia: UFU, 2009, p.233-237.

TFOUNI, Leda Verdiani. Adultos não alfabetizados: o avesso do avesso. Campinas: Pontes, 1988.

THIOLLENT, Michael. Metodologia da pesquisa-ação. 14.ed. São Paulo: Cortez, 2005.

TORO, Fernando de. Semiótica del teatro. Del texto a la puesta en escena. Buenos Aires: Galerna, 1989.

UBERSFELD, Anne. Para ler o teatro. Trad. José Simões. São Paulo: Perspectiva, 2010.

VAL, Maria da Graça Costa. Atividades de produção de textos escritos em livros didáticos de $5^{\text {a }}$ a $8^{\text {a }}$ séries do ensino fundamental. In: ROJO, Roxane Helena Rodrigues; BATISTA, Antônio Augusto Gomes (Orgs.). Livro didático de Língua Portuguesa, Letramento e Cultura da Escrita. Campinas, SP: Mercado de Letras, 2003, p.125-152.

VAL, Maria da Graça Costa; MARCUSCHI, Beth. Apresentação. In: VAL, Maria da Graça Costa; MARCUSCHI, Beth (Orgs.). Livros didáticos de língua portuguesa: letramento e cidadania. Belo Horizonte: Ceale; Autêntica, 2008, p.7-12.

VINCENT, Guy; LAHIRE, Bernard; THIN, Daniel. Sobre a história e a teoria da forma escolar. Educação em Revista, Belo Horizonte, n.33, jun., 2001 p.7-47.

ZURBACH, Christine. (1999). O texto dramático na aula de português: algumas notas para hoje. In: Revista Aprender, n.22. Disponível em: http://www.esep.pt/aprender/index.php/revistas/100-revista-aprender-n-22. Acesso em: março de 2015. 


\section{LIVROS DIDÁTICOS CONSULTADOS}

AZEREDO, Cristina Soares de Lara. Projeto Eco. $8^{\circ}$ ano. São Paulo: Positivo, 2009, p.131150.

BELTRÃO, Eliana Lúcia Santos; GORDILHO, Tereza Cristina Santos. Diálogo Edição Renovada. $8^{\circ}$ ano. São Paulo: FTD, 2009, p.85-94.

CAMPOS, João Carlos Rocha; OLIVEIRA, Gabriela Rodella de. Português a Arte da Palavra. $8^{\circ}$ ano. São Paulo: AJS, 2009, p.46-81.

CEREJA, William Roberto; MAGALHÃES, Thereza Cochar. Português Linguagens. $8^{\circ}$ ano. São Paulo: Atual, 2009, p.18-37, 66-69.

DIAFÉRIA, Celina; PINTO, Mayara. Trajetórias da palavra. $9^{\circ}$ ano. São Paulo: Scipione, 2009, p.221-241.

PENTEADO, Ana Elisa de Arruda; COSTA; Cibele Lopresti; LOUSADA, Eliane Gouvêa et alii. Para viver juntos. $8^{\circ}$ ano. São Paulo: SM, 2008, p.132-161.

SOUZA, Cássia Garcia de; CAVÉQUIA, Márcia Paganini. Linguagem Criação e Interação. $9^{\circ}$ ano. São Paulo: Saraiva, 2010, p.83-108.

TRAVAGLIA, Luiz Carlos; ROCHA, Maura Alves de Freitas; ARRUDA-FERNANDES, Vania Maria Bernardes. A aventura da linguagem. $8^{\circ}$ ano. Belo Horizonte: Dimensão, 2009, p.96-111. 